\title{
Anthropogenic Organic Compounds in Source Water of Select Community Water Systems in the United States, 2002-10
}





\section{Anthropogenic Organic Compounds in Source Water of Select Community Water Systems in the United States, 2002-10}

By Joshua F. Valder, Gregory C. Delzer, James A. Kingsbury, Jessica A. Hopple, Curtis V. Price, and David A. Bender

Scientific Investigations Report 2014-5139 


\title{
U.S. Department of the Interior SALLY JEWELL, Secretary
}

\section{U.S. Geological Survey Suzette M. Kimball, Acting Director}

\author{
U.S. Geological Survey, Reston, Virginia: 2014
}

For more information on the USGS - the Federal source for science about the Earth, its natural and living resources, natural hazards, and the environment, visit http://www.usgs.gov or call 1-888-ASK-USGS.

For an overview of USGS information products, including maps, imagery, and publications, visit http://www.usgs.gov/pubprod

To order this and other USGS information products, visit http://store.usgs.gov

Any use of trade, firm, or product names is for descriptive purposes only and does not imply endorsement by the U.S. Government.

Although this information product, for the most part, is in the public domain, it also may contain copyrighted materials as noted in the text. Permission to reproduce copyrighted items must be secured from the copyright owner.

Suggested citation:

Valder, J.F., Delzer, G.C., Kingsbury, J.A., Hopple, J.A., Price, C.V., and Bender, D.A., 2014, Anthropogenic organic compounds in source water of select community water systems in the United States, 2002-10: U.S. Geological Survey Scientific Investigations Report 2014-5139, 129 p., http://dx.doi.org/10.3133/sir20145139.

ISSN 2328-0328 (online) 


\section{Foreword}

The U.S. Geological Survey (USGS) is committed to providing the Nation with reliable scientific information that helps to enhance and protect the overall quality of life and that facilitates effective management of water, biological, energy, and mineral resources (http://www.usgs. gov//). Information on the Nation's water resources is critical to ensuring long-term availability of water that is safe for drinking and recreation and is suitable for industry, irrigation, and fish and wildlife. Population growth and increasing demands for water make the availability of that water, measured in terms of quantity and quality, even more essential to the long-term sustainability of our communities and ecosystems.

The USGS implemented the National Water-Quality Assessment (NAWQA) Program in 1991 to support national, regional, State, and local information needs and decisions related to water-quality management and policy (http://water.usgs.gov/nawqa). The NAWQA Program is designed to answer: What is the quality of our Nation's streams and groundwater? How are conditions changing over time? How do natural features and human activities affect the quality of streams and groundwater, and where are those effects most pronounced? By combining information on water chemistry, physical characteristics, stream habitat, and aquatic life, the NAWQA Program aims to provide science-based insights for current and emerging water issues and priorities. From 1991 to 2001, the NAWQA Program completed interdisciplinary assessments and established a baseline understanding of water-quality conditions in 51 of the Nation's river basins and aquifers, referred to as Study Units (http://water.usgs.gov/nawqa/studies/ study_units.html).

National and regional assessments are ongoing in the second decade (2002-2010) of the NAWQA Program as 42 of the 51 Study Units are selectively reassessed. These assessments extend the findings in the Study Units by determining water-quality status and trends at sites that have been consistently monitored for more than a decade, and filling critical gaps in characterizing the quality of surface water and groundwater. For example, increased emphasis has been placed on assessing the quality of source water and finished water associated with many of the Nation's largest community water systems. During the second decade, NAWQA is addressing five national priority topics that build an understanding of how natural features and human activities affect water quality, and establish links between sources of compounds, the transport of those compounds through the hydrologic system, and the potential effects of compounds on humans and aquatic ecosystems. Included are studies on the fate of agricultural chemicals, effects of urbanization on stream ecosystems, bioaccumulation of mercury in stream ecosystems, effects of nutrient enrichment on aquatic ecosystems, and transport of compounds to public-supply wells. In addition, national syntheses of information on pesticides, volatile organic compounds (VOCs), nutrients, trace elements, and aquatic ecology are continuing.

The USGS aims to disseminate credible, timely, and relevant science information to address practical and effective water-resource management and strategies that protect and restore water quality. We hope this NAWQA publication will provide you with insights and information to meet your needs, and will foster increased citizen awareness and involvement in the protection and restoration of our Nation's waters. 
The USGS recognizes that a national assessment by a single program cannot address all waterresource issues of interest. External coordination at all levels is critical for cost-effective management, regulation, and conservation of our Nation's water resources. The NAWQA Program, therefore, depends on advice and information from other agencies-Federal, State, regional, interstate, Tribal, and local—as well as nongovernmental organizations, industry, academia, and other stakeholder groups. Your assistance and suggestions are greatly appreciated.

William H. Werkheiser

USGS Associate Director for Water 


\section{Acknowledgments}

The authors gratefully appreciate the assistance of personnel at each community water system sampled in this study.

Personnel at the U.S. Geological Survey (USGS) are appreciated for the collection, processing, and analyses of samples. In addition, Janet Carter, Galen Hoogestraat, and Kathy Lee (USGS) are acknowledged for their review of this document. Jonathan Scott (USGS) is acknowledged for his contribution in the analyses that resulted in the mixtures dataset. Finally, Jack Barbash and Dana Kolpin (USGS) are acknowledged for their contributions in categorizing compounds by their primary uses, which provide a better understanding of potential sources to the environment. 


\section{Contents}

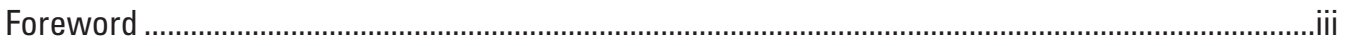

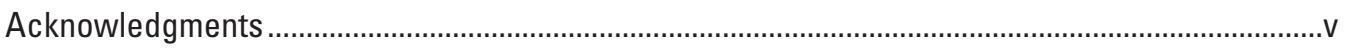

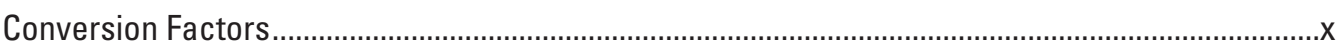

Abbreviations and Symbols..................................................................................................

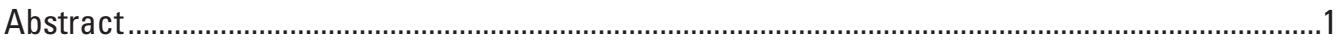

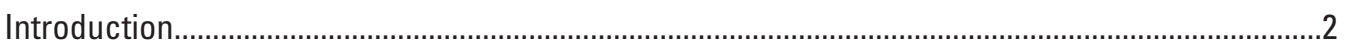

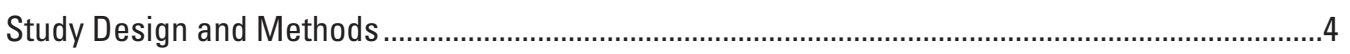

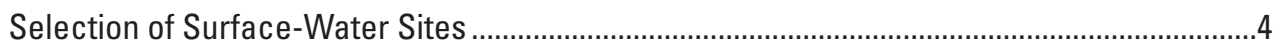

Selection of Groundwater Sites ............................................................................................

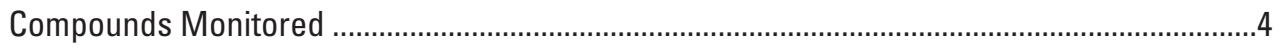

Sample Collection and Protocols ......................................................................................

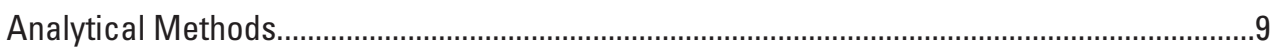

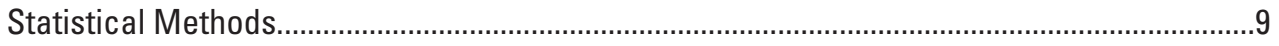

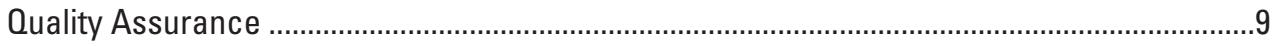

Human-Health Benchmarks Used for Screening-Level Assessments ..................................10

Determination of Commonly Occurring Compounds .........................................................11

Determination of Mixtures Used to Summarize Compound Co-Occurrence...........................11

Characterization of Community Water Systems and Sites Sampled for Anthropogenic

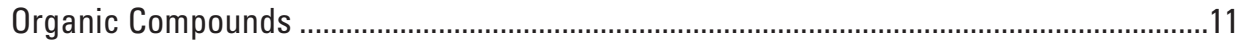

Occurrence of Anthropogenic Organic Compounds in Source Waters..........................................17

Commonly Occurring Anthropogenic Organic Compounds in Surface Water.........................19

Commonly Occurring Anthropogenic Organic Compounds in Groundwater ..........................22

Comparison of Surface Water and Groundwater Occurrence ..............................................24

Comparison of Results to Human-Health Benchmarks in Rivers and Groundwater

Factors Affecting the Occurrence of Compounds in Surface Water

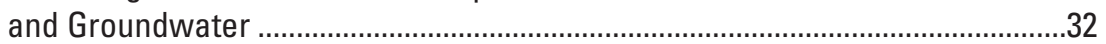

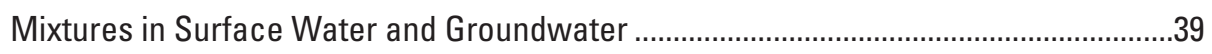

Occurrence of Herbicides and Herbicide Degradates...........................................................4

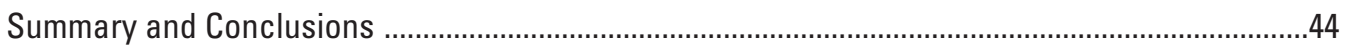

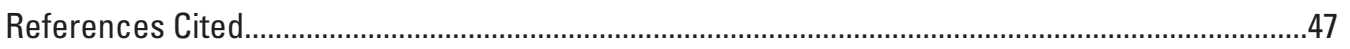

Appendix 1. Compounds Monitored, Chemical Abstract Service Registry Number,

Drinking-Water Benchmark, Primary Use or Source Group, and

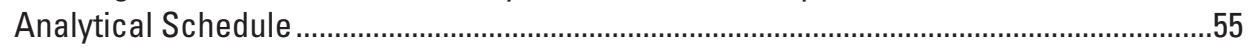

Appendix 2. Summary of the Frequency of Detections in Surface-Water Samples ....................79

Appendix 3. Summary of Frequency of Detections in Groundwater Samples .............................92

Appendix 4. Qualified Concentrations of Compounds Monitored in Surface Water During 2002-10 by Primary Use Group And Human-Health Benchmarks .........................105

Appendix 5. Qualified Concentrations of Compounds Monitored in Groundwater During 2002-09 by Primary Use Group and Human-Health Benchmarks. 


\section{Figures}

1. Maps showing general locations of sampled sites and all community water system sites derived from the Public-Supply Database .....

2. Graph showing distribution of population served for community water systems supplied by 2,016 river intakes in the conterminous United States compared to sampled river intakes.

3. Graphs showing distribution of 2,016 river intakes compared to sampled river intakes.

4. Graph showing distribution of population served for community water systems supplied by 112,099 supply wells in the conterminous United States compared to sampled supply wells.

5. Graphs showing distribution of 112,099 supply wells compared to sampled supply wells.

6. Graph showing commonly occurring compounds in source water derived from surface water

7. Graph showing commonly occurring compounds in source water derived from groundwater

8. Map showing geographic distribution of the number of commonly detected compounds without an assessment level in surface-water and groundwater samples collected from 20 river intakes and 448 supply wells during 2002-10

9. Pie diagrams showing characterization of use groups for commonly occurring compounds in surface water and groundwater.

10. Graphs showing detection frequency and quantified concentrations of 65 commonly occurring compounds in both surface water and groundwater using no assessment level

11. Graphs showing detection frequency and quantified concentrations of commonly occurring herbicide and herbicide degradates and personal-care and domestic-use products in surface water and groundwater

12. Graphs showing detection frequency and quantified concentrations of commonly occurring disinfection by-products and solvents in surface water and groundwater

13. Graph showing commonly occurring compounds with concentrations that exceeded or were within one-tenth of a benchmark in surface water and groundwater

14. Graphs showing relation between median number of commonly occurring compounds detected and the amount of urban and agricultural land use in the watershed or contributing area without an assessment level at surface-water sites and groundwater studies

15. Graphs showing concentrations of herbicides detected without an assessment level in surface-water samples collected from rivers.

16. Graph showing detection frequencies without an assessment level of commonly detected compounds by principal aquifer rock type for samples from 448 supply wells collected during 2002-09.

17. Graphs showing detection frequency without an assessment level of commonly detected compounds within urban and agricultural land-use quartiles for 2,016 river intakes and 112,099 supply wells considered to represent the national distribution of river intakes and supply wells, respectively, supplying community water systems for rivers and supply wells.. 
18. Graphs showing occurrence and concentrations without an assessment level for commonly occurring herbicide and herbicide degradates within agricultural land-use quartiles for 2,016 river intakes and 112,099 supply wells considered to represent the national distribution of river intakes and supply wells, respectively, supplying community water systems for rivers and supply wells.

19. Graphs showing occurrence and concentrations without assessment level of commonly occurring solvents within urban land-use quartiles for 2,016 river intakes and 112,099 supply wells considered to represent the national distribution of river intakes and supply wells, respectively, supplying community water systems for rivers and supply wells

20. Graph showing distribution of the number of co-occurring anthropogenic organic compounds in surface water or groundwater samples collected during 2002-10 with and without a common assessment level...

21. Graphs showing ten most frequently co-occurring compounds evaluated with an assessment level of 0.05 microgram per liter in samples collected from surface water during 2002-10 and groundwater during 2002-09

22. Graphs showing ten most frequently co-occurring compounds evaluated without an assessment level in samples collected from surface water during 2002-10 and groundwater samples during 2002-09

23. Graphs showing relation between summed concentrations of herbicide degradates and concentrations of the parent herbicide for surface water and groundwater

\section{Appendix Figures}

4-1. Graph showing qualified concentrations of disinfection by-products in surface water, 2002-10.

4-2. Graph showing qualified concentrations of fumigant-related compounds in surface water, 2002-10.

4-3. Graph showing qualified concentrations of fungicides and fungicide degradates compounds in surface water, 2002-10.

4-4. Graph showing qualified concentrations of gasoline hydrocarbons, oxygenates, and oxygenate degradates in surface water, 2002-10

4-5. Graph showing qualified concentrations of herbicides and herbicide degradates in surface water, 2002-10

4-6. Graph showing qualified concentrations of insecticides and insecticide degradates in surface water, 2002-10

4-7. Graph showing qualified concentrations of manufacturing additives in surface water, 2002-10.

4-8. Graph showing qualified concentrations of organic synthesis compounds in surface water, 2002-10

4-9. Graph showing qualified concentrations of pavement- and combustion-derived compounds in surface water, 2002-10

4-10. Graph showing qualified concentrations of personal-care and domestic-use products in surface water, 2002-10

4-11. Graph showing qualified concentrations of plant- or animal-derived biochemicals in surface water, 2002-10

4-12. Graph showing qualified concentrations of of solvents in surface water, 2002-10.....116 
5-1. Graph showing qualified concentrations of disinfection by-products in groundwater, 2002-09.

5-2. Graph showing qualified concentrations of fumigant-related compounds in groundwater, 2002-09

5-3. Graph showing qualified concentrations of fungicides and fungicide degradates compounds in groundwater, 2002-09...

5-4. Graph showing qualified concentrations of gasoline hydrocarbons, oxygenates, and oxygenate degradates in groundwater, 2002-09.

5-5. Graph showing qualified concentrations of herbicides and herbicide degradates in groundwater, 2002-09.

5-6. Graph showing qualified concentrations of insecticides and insecticide degradates in groundwater, 2002-09.

5-7. Graph showing qualified concentrations of manufacturing additives in groundwater, 2002-09

5-8. Graph showing qualified concentrations of organic synthesis compounds in groundwater, 2002-09.

5-9. Graph showing qualified concentrations of pavement- and combustion-derived compounds in groundwater, 2002-09.

5-10. Graph showing qualified concentrations of personal-care and domestic-use products in groundwater, 2002-09.

5-11. Graph showing qualified concentrations of plant- or animal-derived biochemicals in groundwater, 2002-09.

5-12. Graph showing qualified concentrations of refrigerants and propellants in products in groundwater, 2002-09.

5-13. Graph showing qualified concentrations of solvents in products in groundwater, 2002-09

\section{Tables}

1. Summary of locations and source of supply for source-water samples collected

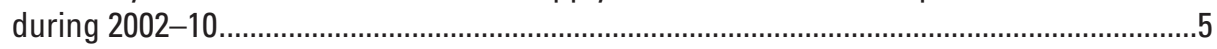

2. Primary use groups for compounds analyzed in source water ...........................................8

3. Summary of commonly occurring compounds in surface water ......................................12

4. Summary of ancillary variables characterized in each of 2,016 watersheds for river intakes and 112,099 contributing areas for supply wells used in relational analysis......16

5. Land-use classification[ $>$, greater than; $\leq$, less than or equal to; $<$, less than] ...............19

6. List of compounds without a human-health benchmark that were detected in greater than 10 percent of samples from surface water or groundwater, or both..........32

7. Number of study sites sampled within land-use quartiles for 2,016 river intakes and 112,099 supply wells considered to represent the national distribution of river intakes and supply wells, respectively, supplying community water systems 


\section{Appendix Tables}

1. Compounds monitored, Chemical Abstract Service Registry number, drinking-water benchmark, primary use or source group, and

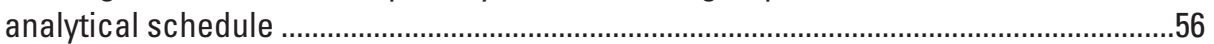

2. Summary of the frequency of detections in surface-water samples .............................80

3. Summary of frequency of detections in groundwater samples ......................................93

\section{Conversion Factors}

\begin{tabular}{lcl}
\multicolumn{1}{c}{ SI to Inch/Pound } & \multicolumn{1}{c}{ Bultiply } & To obtain \\
\hline & Length & foot $(\mathrm{ft})$ \\
meter $(\mathrm{m})$ & 3.281 & mile $(\mathrm{mi})$ \\
kilometer $(\mathrm{km})$ & 0.6214 & \\
\hline & Area & square mile $\left(\mathrm{mi}^{2}\right)$ \\
\hline square kilometer $\left(\mathrm{km}^{2}\right)$ & 0.3861 & \\
\hline & Volume & gallon $(\mathrm{gal})$ \\
\hline liter $(\mathrm{L})$ & 0.2642 & gallon per minute $(\mathrm{gal} / \mathrm{min})$ \\
\hline
\end{tabular}

Vertical coordinate information is references to the North American Vertical Datum of 1988 (NAVD 88).

Horizontal coordinate information is referenced to the North American Datum of 1983 (NAD 83).

Concentrations of chemical constituents in water are given in micrograms per liter $(\mu \mathrm{g} / \mathrm{L})$. 


\section{Abbreviations and Symbols}

$<$

$\mathrm{C}<$

$\mu \mathrm{g} / \mathrm{L}$

AHTN

$\mathrm{AOC}$

BO

CCL

CCL3

CWS

DEET

E

EPA

ESA

GC/MS

GRAS

HBSL

HHCB

HPLC/MS

LRL

MCL

MEK

MTBE

NAWQA

NWIS

NWQL

PAH

PCE

PSDB

$p$-value

PVC

PWS

SDWA

SDWIS less than

censored concentration

micrograms per liter

acetyl hexamethyl tetrahydronaphthalene

anthropogenic organic compound

benchmark quotient

Contaminant Candidate List (U.S. Environmental Protection Agency)

Contaminant Candidate List 3 (U.S. Environmental Protection Agency)

community water system

$\mathrm{N}, \mathrm{N}$-diethyl-meta-toluamide

estimated

U.S. Environmental Protection Agency

ethane sulfonic acid

gas chromatography/mass spectrometry

Generally Recognized As Safe (U.S. Food and Drug Administration)

Health-Based Screening Level (U.S. Geological Survey)

hexahydrohexamethylcyclopentabenzopyran

high-performance liquid chromatography/mass spectrometry

laboratory reporting level

Maximum Contaminant Level (U.S. Environmental Protection Agency)

methyl ethyl ketone

methyl tert-butyl ether

National Water-Quality Assessment (U.S. Geological Survey)

National Water Information System (U.S. Geological Survey)

National Water Quality Laboratory (U.S. Geological Survey)

polynuclear aromatic hydrocarbon

perchloroethene

Public Supply Database (U.S. Environmental Protection Agency)

probability value

polyvinyl chloride

public drinking-water system

Safe Drinking Water Act

Safe Drinking Water Information System (U.S. Environmental Protection Agency) 


$\begin{array}{ll}\text { SWOA } & \text { Source Water-Quality Assessment (U.S. Geological Survey) } \\ \text { TCE } & \text { trichloroethene } \\ \text { UCMR } & \begin{array}{l}\text { Unregulated Compound Monitoring Rule (U.S. Environmental Protection } \\ \text { Agency) }\end{array} \\ \text { USGS } & \text { U.S. Geological Survey } \\ \text { VOC } & \text { volatile organic compound }\end{array}$




\title{
Anthropogenic Organic Compounds in Source Water of Select Community Water Systems in the United States, 2002-10
}

\author{
By Joshua F. Valder, Gregory C. Delzer, James A. Kingsbury, Jessica A. Hopple, Curtis V. Price, and David A. \\ Bender
}

\section{Abstract}

Drinking water delivered by community water systems (CWSs) comes from one or both of two sources: surface water and groundwater. Source water is raw, untreated water used by CWSs and is usually treated before distribution to consumers. Beginning in 2002, the U.S. Geological Survey's (USGS) National Water-Quality Assessment Program initiated Source Water-Quality Assessments (SWQAs) at select CWSs across the United States, primarily to characterize the occurrence of a large number of anthropogenic organic compounds that are predominantly unregulated by the U.S. Environmental Protection Agency.

Source-water samples from CWSs were collected during 2002-10 from 20 surface-water sites (river intakes) and during 2002-09 from 448 groundwater sites (supply wells). River intakes were sampled approximately 16 times during a 1 -year sampling period, and supply wells were sampled once. Samples were monitored for 265 anthropogenic organic compounds. An additional 3 herbicides and 16 herbicide degradates were monitored in samples collected from 8 river intakes and 118 supply wells in areas where these compounds likely have been used. Thirty-seven compounds have an established U.S. Environmental Protection Agency (EPA) Maximum Contaminant Level (MCL) for drinking water, 123 have USGS Health-Based Screening Levels (HBSLs), and 29 are included on the EPA Contaminant Candidate List 3. All compounds detected in source water were evaluated both with and without an assessment level and were grouped into 13 categories (hereafter termed as "use groups") based on their primary use or source.

The CWS sites were characterized in a national context using an extract of the EPA Safe Drinking Water Information System to develop spatially derived and system-specific ancillary data. Community water system information is contained in the EPA Public Supply Database, which includes 2,016 active river intakes and 112,099 active supply wells. Ancillary variables including population served, watershed size, land use, population density, and recharge were characterized for each of the watersheds for river intakes and contributing areas for supply wells.

A total of 313 samples were collected from 20 river intakes. Between the years of 2002 through 2010, samples were collected approximately 16 times over the course of a year. Seventy-one compounds from 12 of the 13 use groups commonly occurred (detected in greater than or equal to 1 percent of samples using an assessment level of 0.05 microgram per liter or when a compound was detected in greater than or equal to 10 percent of samples without an assessment level) indicating a wide variety of sources and pathways to these rivers and highlighting the importance of source-water protection strategies.

A total of 448 supply wells were sampled once during 2002-10 as part of 30 independent groundwater studies. About 15 CWS supply wells were sampled for each independent groundwater study. Twenty-eight compounds from 7 of the 13 use groups commonly occurred indicating a wide variety of sources and pathways exist for these compounds to reach these wells and highlighting the importance of wellhead protection strategies.

About one-half the 265 compounds monitored (122) were detected in both surface water and groundwater samples. A more diverse suite of compounds were detected in surface water in comparison to groundwater. However, herbicides and herbicide degradates were the most frequent group of compounds detected in both surface water and groundwater. Sixty-five of the most commonly occurring compounds were detected in one or more samples from both surface water and groundwater.

Human-health benchmarks (MCLs for regulated compounds and HBSLs for unregulated compounds) were available for more than one-half the compounds (160 of the 265) monitored in this study. Fifty-eight percent (41 of 71) of the commonly occurring compounds in surface water have a human-health benchmark to which concentrations can be compared; 19 have MCLs and 22 have HBSLs. Eighty-three percent (24 of 28) of the most commonly occurring compounds in groundwater have a human-health benchmark for 
which concentrations can be compared; 14 have MCLs and 10 have HBSLs.

To put results from this study into context with the national distribution of river intakes and supply wells used by CWSs, sites were grouped into the respective national population of land-use quartiles. The increase in compound occurrence with increasing urban and agricultural land use in the watershed or contributing area was more evident for rivers than for supply wells. The increase in detection frequency of herbicides and herbicide degradates with increasing agricultural land use was more evident for rivers than for supply wells. The occurrence of solvents did not change substantially with increasing urban land use for rivers or supply wells.

Basic co-occurrence analyses were completed with and without an assessment level. Considering all detections in surface water without an assessment level, approximately 86 percent of source-water samples contained 2 or more compounds, and 50 percent of samples contained at least 14 compounds. Considering all detections in groundwater without an assessment level, 50 percent of samples contained at least three compounds. For the most part, the compounds detected most frequently as individual compounds in the environment often composed the most frequent unique mixtures. Five of the 10 most frequently co-occurring unique mixtures in both surface water and groundwater were the same: atrazine and deethylatrazine; atrazine and chloroform; deethylatrazine and simazine; atrazine and simazine; and deethylatrazine, atrazine, and simazine. Because similar mixtures were identified in both surface water and groundwater without an assessment level, future studies could be directed toward better understanding the toxicological importance of these unique mixtures.

Summed concentrations of herbicide degradates were compared to concentrations of the parent herbicides in surfacewater and groundwater samples collected from 8 river intakes and 118 CWS wells, from which samples were analyzed for an additional 3 herbicides and 16 degradates. The toxicity to humans for many of these degradate products is largely unknown and thus points to the importance of monitoring these compounds (both the parent and degradate) in the environment.

This study highlights the importance of anthropogenic organic compounds in source water of select CWSs in the United States by characterizing their occurrence in surfacewater and groundwater samples. Compound concentrations and occurrence are summarized and evaluated in a humanhealth context, when possible. Additionally, compounds found to co-occur as mixtures for both surface water and groundwater highlight the significance of low-level compound co-occurrence.

\section{Introduction}

The quality of the Nation's drinking-water supply is an issue of national importance because it is essential to public health (U.S. General Accounting Office, 1997). In 2008, about 155,000 public drinking-water systems (PWSs) were in operation in the United States (U.S. Environmental Protection Agency, 2010). A PWS is defined by the Safe Drinking Water Act (SDWA) as one that serves piped drinking water to at least 25 people or 15 service connections for at least 60 days a year (U.S. Environmental Protection Agency, 2003). Public drinking-water systems provide drinking water to about 312 million people. Only about 52,000 of the 155,000 PWSs are considered community water systems (CWSs) that supply water to the same population year round (U.S. Environmental Protection Agency, 2010). However, most of the population (about 292 million) receives their drinking water from CWSs (U.S. Environmental Protection Agency, 2003).

Drinking water delivered by CWSs comes from one or both of two sources: surface water and groundwater (hereafter termed "source water"). Source water is raw, untreated water used by CWSs and is usually treated before distribution to consumers. Finished water is defined as water that has passed through a water treatment plant, such that all the treatment processes are completed, or "finished" (Symons and others, 2000). Community water systems are required to monitor their finished water for about 90 regulated compounds; however, more than 22 million known organic and inorganic substances are known to exist, of which nearly 6 million are commercially available (Reiter and others, 2004; U.S. Environmental Protection Agency, 2009a). Current analytical capabilities cover only a very small fraction of compounds potentially in the environment that may enter our Nation's drinking-water supply (Olsen and others, 2013).

The SDWA was passed by Congress in 1974 to protect public health by regulating the Nation's public drinking-water supply (U.S. Environmental Protection Agency, 2009b). Originally, the SDWA aimed primarily at treatment as the means of providing safe drinking water. The SDWA was subsequently amended in 1986 and 1996; it now requires many additional actions, such as source-water protection, to protect source water and drinking water. The SDWA requires the U.S. Environmental Protection Agency (EPA) to establish enforceable national health-based standards, called Maximum Contaminant Levels (MCLs), for drinking water to protect against public health risks associated with naturally occurring and anthropogenic compounds (U.S. Environmental Protection Agency, 2004). The SDWA also broadly defines a "contaminant" as "any physical, chemical, biological, or radiological substance or matter in water" (U.S. Senate, 2002).

The SDWA gives the EPA the responsibility to periodically publish a list of unregulated compounds called the Contaminant Candidate List (CCL). The purpose of the CCL is to help assess the need for new drinking-water regulations to address occurrence of unregulated compounds. The most current list (as of 2013), Contaminant Candidate List 3 (CCL3), contains a list of 104 compounds or compound groups that currently are not subject to any proposed national primary drinking-water regulations, that are known or anticipated to occur in PWSs, and which may require regulation by the 
SDWA in the future (U.S. Environmental Protection Agency, 2012a). After publishing each CCL, EPA also decides whether to regulate at least five compounds from the most current CCL in drinking water based on the compound's potential for adverse human-health effects, occurrence in PWSs, and a meaningful opportunity to protect public health; these decisions are called "regulatory determinations" (U.S. Environmental Protection Agency, 2012a). To help characterize the occurrence of compounds on the CCL3, the EPA required about 5,000 PWSs to monitor 25 of the compounds during 2008-10 as part of the Unregulated Compound Monitoring Rule (UCMR) (U.S. Environmental Protection Agency, 2008a). Data obtained from the UCMR on the occurrence of unregulated compounds, along with results from USGS and other monitoring activities, are used by EPA as part of both the $\mathrm{CCL}$ and regulatory determination processes (Toccalino and Hopple, 2010).

Unfortunately, sparse toxicity information exists for unregulated compounds to determine the significance of occurrence information in a human-health context. Furthermore, the occurrence of mixtures in source water is a matter of increasing concern and attention because the total combined toxicity of compounds in water may be greater than that of any individual compound. Little is known about the potential health effects associated with exposure to multiple compounds, and more investigation is needed to evaluate the potential toxicity of mixtures to humans (Hasegawa and others, 1994; Yang, 1994). In addition, little is known about the human-health significance of degradation products. For example, herbicide degradates may have less, similar, or greater toxicity than parent compounds (Hladik and others, 2005).

Characterizing source water is important to better understand, in part, which compounds occur through natural occurrence, animal activity, or as a result of anthropogenic effects. This information is valuable to regulatory agencies and water treatment industries. Additionally, the most frequently co-occurring compounds can be identified, which may guide future research to evaluate the potential toxicity of these mixtures to humans. Understanding co-occurrence of compounds is important because little is known on the cumulative human-health effects of multiple compounds that occur at lowlevel concentrations (Yang, 1994; Carpenter and others, 2002; Toccalino and others, 2010). The need to better understand these co-occurring compounds has increased, and an emerging area of science has begun to assess the potential effects of mixtures in the environment (Hertzberg and MacDonell, 2002; Agency for Toxic Substances and Disease Registry, 2004; U.S. Environmental Protection Agency, 2007). This study was designed to identify those unique mixtures of anthropogenic organic compounds (AOCs) that are most commonly detected in source water derived from rivers and groundwater.

Few studies have described the occurrence of AOCs in source water derived from rivers and groundwater. This study focuses on characterizing the occurrence of AOCs in source water derived from either rivers or groundwater. The occurrence of AOCs in rivers has been described, in part, by Gilliom and others (1985), Gilliom and others (2006), Westrick (1990), and Kolpin and others (2002); some of these studies were synoptic, focused on ambient streams in different land-use settings, whereas other studies involved targeted sampling of rivers with a greater likelihood of detecting certain compounds. However, these studies did not focus on water specifically used for drinking water, and the sites sampled for these studies were not near CWS intakes. The occurrence of AOCs in groundwater has been documented, in part, by Westrick and others (1984), U.S. Environmental Protection Agency (2002), Gilliom and others (2006), and Zogorski and others (2006).

During 2002-12, the U.S. Geological Survey's (USGS's) National Water-Quality Assessment (NAWQA) Program completed studies at select CWSs across the United States (Delzer and Hamilton, 2007). The primary objective of these studies, termed Source Water-Quality Assessments (SWQAs), was to characterize the occurrence of a large number of predominantly unregulated AOCs in source water of CWSs. Kingsbury and others (2008) and Hopple and others (2009) summarized initial findings from this study for surface water and groundwater, respectively. This report summarizes source-water results for the entire 10-year study for which samples were collected during 2002-10.

The laboratory analytical methods used in this study attain relatively low minimum detection levels - commonly 100 to 1,000 times lower than State and Federal standards and guidelines for protecting water quality. Detections, therefore, do not necessarily indicate a concern to human health but instead may identify emerging water-quality issues and can be used to track changes in occurrence and concentrations through time. This study is intended to complement existing Federal, State, and local drinking-water monitoring programs, which focus primarily on post-treatment compliance monitoring of compounds regulated by EPA in finished drinking water to meet requirements of the SDWA. This study also provides information for many compounds not included in other source-water and finished-water monitoring programs such as the UCMR (U.S. Environmental Protection Agency, 2008a) and the U.S. Department of Agriculture's Pesticide Data Program (U.S. Department of Agriculture, 2008). In addition, this SWQA study contributes to specific science goals and priorities of the USGS, which, in part, include assessment of environmental risk to public health and the quality of water used for drinking water, as important aspects of accounting for the freshwater resources of the Nation (U.S. Geological Survey, 2007a).

The primary purpose of this report is to characterize the most commonly occurring AOCs in source water of CWSs that withdraw water solely from surface water (rivers) or groundwater (supply wells). Source-water samples were collected during 2002-10 from 20 river intakes and 448 supply wells. Rivers were sampled approximately 16 times over the course of a year and supply wells were sampled once. Samples from all sites were analyzed for 265 compounds that included disinfection by-products, fumigant-related compounds, fungicides, 
gasoline hydrocarbons, herbicides, insecticides, manufacturing additives, organic synthesis compounds, pavement- and combustion-derived compounds, personal-care products, plant- or animal-derived biochemicals, refrigerants and propellants, and solvents. An additional 3 herbicides and 16 herbicide degradates (appendix 1) were analyzed in samples collected from sites in areas where these compounds likely have been used based on agricultural land use. This report describes (1) the sites sampled in a national context; (2) the occurrence of AOCs in surface-water and groundwater source water; and (3) a comparison of results between surface water and groundwater. Compound concentrations are evaluated in a human-health context, when possible, through comparison to EPA MCLs and USGS Health-Based Screening Levels (HBSLs). Specific ancillary factors determined to be associated with the occurrence and concentrations of compounds in source water and the most frequently co-occurring compounds are presented. Lastly, the occurrence of the additional herbicide degradates and their parent herbicides are presented.

\section{Study Design and Methods}

The CWSs selected for monitoring met several criteria for surface-water and groundwater sites. Sites were located in NAWQA study areas where data from this study can be compared to other data collected during 1992 through 2012 from other sites within those study areas. The CWSs ideally were single-source systems (either groundwater or surface water) with little to no blending of water from multiple sources, and larger systems were preferred. The type of water treatment, previous monitoring results, including those for compliance monitoring, and the type of land use in the watershed or near the supply wells were not considered in the selection process.

\section{Selection of Surface-Water Sites}

A total of 20 surface-water sites were selected for monitoring during 2002-10 (table 1; fig. 1). Sites were located on free-flowing reaches of rivers. Systems withdrawing from reservoirs with extensive residence times (on the order of days) were excluded to remain consistent with other river studies conducted by the NAWQA Program. However, in all cases, streamflow in the river could be affected by releases from upstream reservoirs. The mean distance between the CWS river intake and an upstream reservoir was about 40 kilometers $(\mathrm{km})$, where the farthest reservoir was more than $130 \mathrm{~km}$ upstream from the intake.

The CWSs supplied by surface water (specifically, rivers) in this study represent a range in size of population served and are fairly well distributed across the United States. Nineteen of the 20 CWSs supplied by surface water are categorized as large or very large water systems (Carter and others, 2010), meaning that they provide water to more than 10,001 and 100,001 people, respectively (U.S. Environmental Protection
Agency, 2012b). One CWS was small, serving between 501 and 3,300 people.

\section{Selection of Groundwater Sites}

A total of 448 CWS supply wells were sampled during 2002-10 as part of 30 independent groundwater studies (table 1; fig. 1). About 15 CWS wells were sampled for each groundwater study. The highest producing wells in each CWS typically were prioritized for sampling because these wells commonly have the largest contributing areas. Annual production data obtained from the CWSs were used to characterize withdrawals from the wells. In some cases, annual production data for individual wells were not available, so production volume for a well field or pumping center was used. Quartiles of production volumes were calculated among individual wells or pumping centers in a study, and $15 \mathrm{CWS}$ wells were randomly selected from those in the top quartile. For CWSs where the top quartile did not contain enough wells or pumping centers for a random selection of 15 wells, a larger group of wells (for example, those in the upper two quartiles of production volume) was used for the random selection.

Selected wells were at least $1 \mathrm{~km}$ apart to minimize overlapping contributing areas. In general, wells sampled in this study are considered susceptible to anthropogenic contamination because of the relatively high pumping rates [generally greater than 32 liters per second (L/s)] and correspondingly large contributing areas. The results of this study are, therefore, not necessarily representative of wells with relatively low pumping rates (less than $32 \mathrm{~L} / \mathrm{s}$ ).

In certain aquifer systems, some of the highest-producing CWS wells were located near surface-water bodies, which could result in induced infiltration of surface water to the wells. The wells with this possible connection to rivers (groundwater under the influence of surface water) were avoided. Similarly, CWS wells in coastal or bay areas with induced infiltration from seawater, and wells used for injection and subsequent withdrawal of artificial recharge also were excluded because water samples from these types of wells do not typically represent recharge from the land surface.

\section{Compounds Monitored}

Compounds monitored were selected on the basis of known or potential human-health concerns, analytical capabilities, and whether the compounds typically are not monitored in source water or finished water (appendix 1). Some compounds without known human-health concerns, such as caffeine, were included as potential indicators or surrogates for compounds not monitored. Most of the 265 compounds monitored at all sites are not regulated in drinking water and typically are not monitored by CWSs; however, 37 compounds are monitored and do have an established EPA MCL for drinking water. In addition, 29 compounds included on the CCL3 were monitored. Several inorganic compounds were 
Table 1. Summary of locations and source of supply for source-water samples collected during 2002-10.

[ $n$, number of study locations; NAWQA, National Water-Quality Assessment]

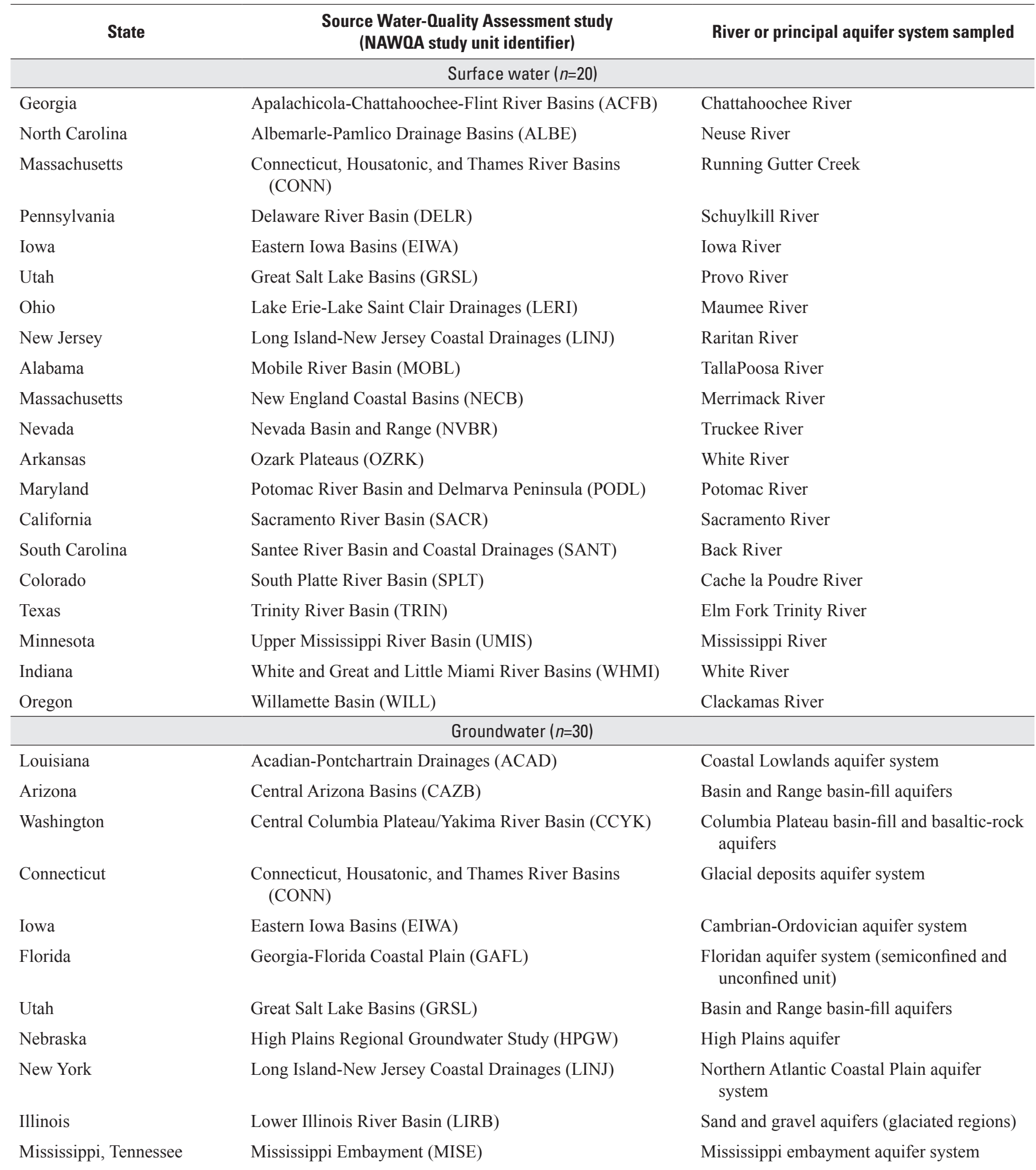


Table 1. Summary of locations and source of supply for source-water samples collected during 2002-10.-Continued

[ $n$, number of study locations; NAWQA, National Water-Quality Assessment]

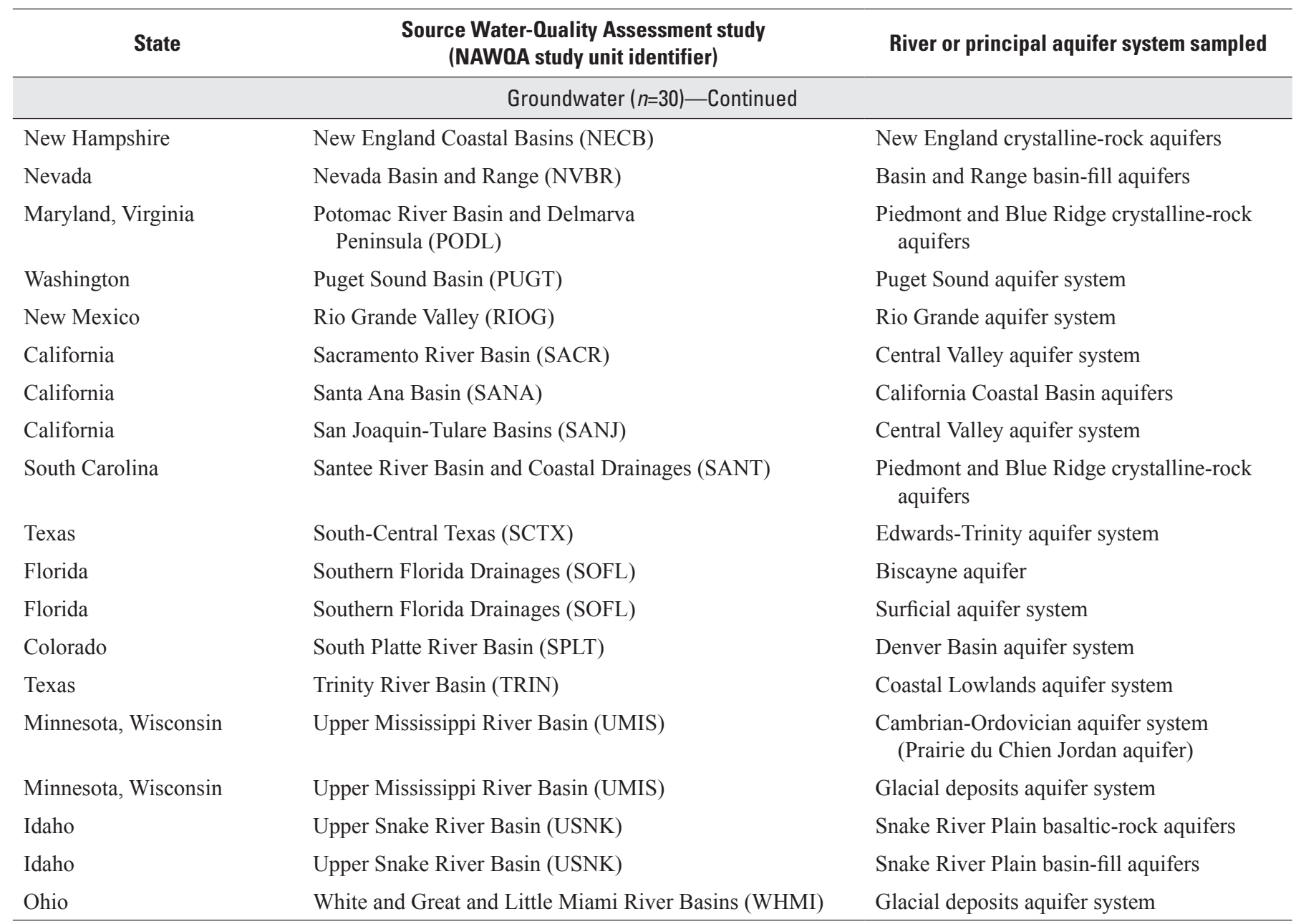

considered for monitoring but were not included because they typically are monitored by CWSs and, thus would not have provided new information. Additionally, only compounds that could be analyzed using USGS approved analytical methods (appendix 1) were considered for monitoring.

Of the 295 compounds initially monitored, 11 were removed because of observed systematic contamination, analytical variability, or because the compound was no longer analyzed by current (2014) USGS analytical methods. Nineteen herbicides and herbicide degradates were only sampled at select sites. The remaining 265 compounds monitored at all sites were grouped into 13 categories on the basis of their primary use or source. The number of compounds in each of the 13 categories (hereafter termed "use groups") varies, ranging from 3 to 68 (table 2). About one-half of the compounds monitored are pesticides, which include herbicides and herbicide degradates, insecticides and insecticide degradates, and fungicides and fungicide degradates. About
90 volatile organic compounds (VOCs) were categorized in six use groups, including disinfection by-products; fumigantrelated compounds; gasoline hydrocarbons, oxygenates, and oxygenate degradates; organic synthesis compounds; refrigerants and propellants; and solvents. Pesticides and VOCs have been monitored by the NAWQA Program since its inception (1991); however, most of the compounds in the remaining four use groups have not been monitored previously by the NAWQA Program (Gilliom and others, 2006; Zogorski and others, 2006). These use groups include personal-care and domestic-use products, such as triclosan (an anti-bacterial agent in many hand soaps), detergent metabolites, and fragrance compounds; manufacturing additives, such as plasticizers and fire retardants; pavement- and combustion-derived compounds, which are predominantly polynuclear aromatic hydrocarbons (PAHs); and plant- or animal-derived biochemicals, such as cholesterol. 

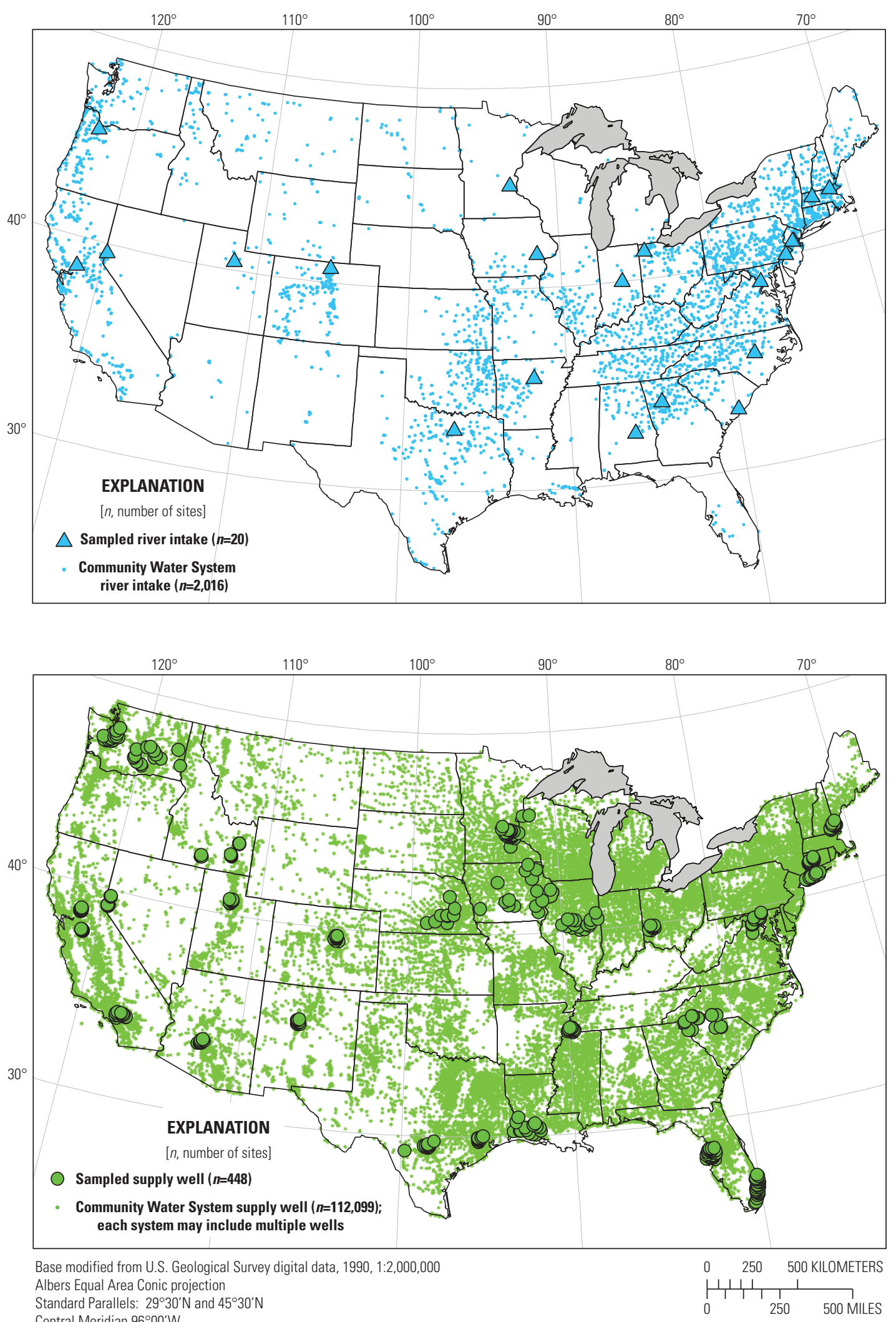

Standard Parallels: $29^{\circ} 30^{\prime} \mathrm{N}$ and $45^{\circ} 30^{\prime} \mathrm{N}$

Central Meridian $96^{\circ} 00^{\prime} \mathrm{W}$

Horizontal coordinate information referenced to the

North American Datum of 1983 (NAD 83)

Figure 1. General locations of sampled sites and all community water system sites derived from the Public-Supply Database. $A$, river intakes, and $B$, supply wells (data downloaded in 2010 from the U.S. Environmental Protection Agency's Safe Drinking Water Information System; Curtis V. Price, U.S. Geological Survey, written commun., 2012). 
Table 2. Primary use groups for compounds analyzed in source water.

\begin{tabular}{|c|c|c|}
\hline Primary use or source group & Description & $\begin{array}{l}\text { Number of } \\
\text { compounds in } \\
\text { group for samples } \\
\text { analyzed }\end{array}$ \\
\hline $\begin{array}{l}\text { Fungicides and fungicide } \\
\text { degradates }\end{array}$ & Pesticides that are used to kill unwanted fungi. & 9 \\
\hline $\begin{array}{l}\text { Gasoline hydrocarbons, } \\
\text { oxygenates, and oxygenate } \\
\text { degradates }\end{array}$ & $\begin{array}{l}\text { Gasoline hydrocarbons are straight, branched, and (or) cyclic organic compounds that } \\
\text { are highly volatile, contain only carbon and hydrogen atoms, and are common } \\
\text { ingredients in gasoline and other petroleum products. Among these compounds, } \\
\text { BTEX (benzene, toluene, ethylbenzene, and xylene) compounds are among those } \\
\text { present in the greatest proportions in gasoline. Oxygenates such as methyl tert-butyl } \\
\text { ether (MTBE) are compounds that contain only carbon, hydrogen, and oxygen } \\
\text { atoms and are commonly added to gasoline to improve the efficiency of combustion. } \\
\text { Oxygenate degradates are formed during the production, storage, release, or use of } \\
\text { gasoline oxygenates or following their release into the environment. }\end{array}$ & 27 \\
\hline $\begin{array}{l}\text { Herbicides and herbicide } \\
\text { degradates }\end{array}$ & $\begin{array}{l}\text { Pesticides designed to kill unwanted plants (herbicides) and compounds produced } \\
\text { from the transformation of the parent herbicide following application (degradates). }\end{array}$ & 68 \\
\hline $\begin{array}{l}\text { Insecticides and insecticide } \\
\text { degradates }\end{array}$ & $\begin{array}{l}\text { Pesticides designed to kill unwanted insects (insecticides) and compounds produced } \\
\text { from the transformation of the parent insecticide following application (degradates). }\end{array}$ & 57 \\
\hline Manufacturing additives & $\begin{array}{l}\text { Compounds used in commercial formulations of chemical products in order to } \\
\text { improve the effectiveness of the product, including plasticizers (to increase the flex- } \\
\text { ibility of plastics), fire retardants, corrosion inhibitors, and pesticide adjuvants. }\end{array}$ & 6 \\
\hline $\begin{array}{l}\text { Personal-care and domestic-use } \\
\text { products }\end{array}$ & $\begin{array}{l}\text { Compounds that are present in commercial products sold for personal or residential } \\
\text { use, such as fragrances, pharmaceuticals, insect repellants, dyes, detergents, } \\
\text { disinfectants, shampoos, and chemicals used in fire extinguishers. }\end{array}$ & 22 \\
\hline $\begin{array}{l}\text { Plant- or animal-derived bio- } \\
\text { chemicals }\end{array}$ & $\begin{array}{l}\text { Naturally occurring compounds that are produced by plants or animals, either through } \\
\text { direct biosynthesis or through the metabolic alteration of compounds ingested or } \\
\text { taken up from other sources. These compounds are predominantly unsaturated } \\
\text { solid alcohols of the steroid group naturally occurring in fatty tissues of plants and } \\
\text { animals and present in animal fecal material. }\end{array}$ & 5 \\
\hline Refrigerants and propellants & $\begin{array}{l}\text { Volatile compounds that are used for commercial or domestic refrigeration, as blowing } \\
\text { agents in the manufacture of packaging and other highly porous materials, or for } \\
\text { dispensing other substances from spray cans and other aerosol delivery devices. }\end{array}$ & 3 \\
\hline Solvents & $\begin{array}{l}\text { Compounds that are used to dissolve other substances. Two of the more common } \\
\text { solvents are trichloroethene (TCE) and perchloroethene (PCE). }\end{array}$ & 32 \\
\hline Total number of compounds & & 265 \\
\hline
\end{tabular}




\section{Sample Collection and Protocols}

Source water and quality-control samples were collected and processed following established USGS sampling protocols (U.S. Geological Survey, variously dated). Surface-water samples from rivers were collected monthly with additional samples collected during selected flow conditions when water quality could change quickly or when concentrations or the number of compounds expected to occur were maximized. These samples were collected from the river as close as practical to the drinking-water intake. Groundwater samples were collected once at the wellhead of the supply well before any treatment such as chlorination.

\section{Analytical Methods}

Samples were analyzed using USGS approved analytical methods at the USGS National Water Quality Laboratory (NWQL) in Lakewood, Colorado, including gas chromatography/mass spectrometry (GC/MS) and high-performance liquid chromatography/mass spectrometry (HPLC/MS). Samples collected for VOC analyses were chilled upon collection. One VOC analytical method required additional preservation using 1:1 hydrochloric acid to achieve a $\mathrm{pH}$ of 2 , whereas a second analytical method did not require the addition of hydrochloric acid. Samples for both VOC analytical methods were analyzed by purge and trap GC/MS (Connor and others, 1998; Rose and Sandstrom, 2003). Samples for analyses of pesticides and other semivolatile compounds were filtered in the field through a 0.7 -micron baked glass-fiber filter and chilled. These samples were extracted at the NWQL on solid-phase extraction cartridges to concentrate the analytes from the filtered samples. The solid-phase extraction cartridges then were eluted with a solvent, and the extracts were analyzed by either GC/MS or HPLC/MS methods (Zaugg and others, 1995, 2002; Lindley and others, 1996; Furlong and others, 2001; Sandstrom and others, 2001; Madsen and others, 2003). At a subset of sites, an additional sample was collected for the analysis of 3 herbicides and 16 herbicide degradates. These samples were analyzed using HPLC/MS by the USGS Organic Geochemistry Research Group Laboratory, in Lawrence, Kansas (Lee and Strahan, 2003).

The analytical methods used at the NWQL and Organic Geochemistry Research Group Laboratory allow for the identification and quantification of compounds at low concentrations, in some cases as low as a few parts per trillion. Each analytical method has different ranges in sensitivity for its suite of analytes. Thus, the laboratory reporting levels (LRLs) for the compounds analyzed span four orders of magnitude, from 0.002 to 8.0 micrograms per liter $(\mu \mathrm{g} / \mathrm{L})$ with a median of $0.04 \mu \mathrm{g} / \mathrm{L}$. Some reported concentrations are qualified as estimated (indicated with an "E"), which means the identification of the compound is reliable, but the concentration has greater uncertainty than unqualified concentrations reported for the same compound. These concentrations are estimated for one of several reasons: (1) they are less than the lowest calibration standard; (2) the sample matrix interfered with measurement of the compound; (3) surrogates added to the sample indicated poor performance during the analysis; or (4) the compound consistently has poor recoveries, and therefore, concentrations are always reported as estimated.

The sensitivity of analytical methods can affect the calculated detection frequencies of the compounds monitored in this study. Compounds with low LRLs likely will be detected more commonly than those with high LRLs, given equal concentration distributions in the environment. To compare detection frequencies among compounds, a common assessment level of $0.05 \mu \mathrm{g} / \mathrm{L}$ was applied to the concentration data to account for the different LRLs. The use of a common assessment level enables comparisons of the occurrence of multiple compounds by reducing potential bias resulting from certain compounds having greater analytical sensitivity than others. In this report, a common assessment level of $0.05 \mu \mathrm{g} / \mathrm{L}$ was used. Seventyfive percent of all compounds analyzed have a LRL of $0.05 \mu \mathrm{g} / \mathrm{L}$ or less. Analytical results for compounds detected in source water were evaluated both with and without an assessment level. In general, for comparisons of the occurrence between one compound and another compound, a common assessment level was used and any concentration less than or equal to $0.05 \mu \mathrm{g} / \mathrm{L}$ was considered less than the LRL (that is, treated as a nondetected concentration). However, for comparisons of the occurrence of an individual compound between multiple locations, or for comparisons of the occurrence of one use group in source-water derived between surface water and groundwater, no assessment level was used, and all concentrations, including those qualified as estimated, were evaluated.

\section{Statistical Methods}

The rank sum test, described by Helsel and Hirsch (2002), was used to compare surface water and groundwater concentrations. A threshold significance level ( $p$-value) of 0.05 was used. A $p$-value less than 0.05 indicates that the test is significant. The $p$-value of 0.05 is a commonly used significance level (Sokal and Rohlf, 1995).

\section{Quality Assurance}

Quality-assurance/quality-control samples collected for SWQA studies include equipment blanks, field blanks, source solution blanks, replicate samples, and finishedwater matrix spikes. The various blank samples consisted of nitrogen-purged organic-free blank water. Equipment blanks typically are collected in a laboratory setting using the same sampling equipment used to collect environmental samples and typically are collected in a controlled environment before the environmental samples are collected. Equipment blanks are used to evaluate the cleanliness of sampling equipment before use. Field blanks are collected at or near sampling sites and are processed in the field in the same manner as 
environmental samples. Field blanks are used to evaluate potential sample contamination from sampling equipment, cleaning procedures, the atmosphere, and shipment to the laboratory. Source solution blanks are used to determine the presence or absence of compounds in the water used to clean equipment and process equipment and field blanks. The various blank samples also provide information on contamination during shipment. Replicate samples measure the combined precision of sampling and laboratory analyses. The various blanks and replicates are summarized by Carter and others (2010). Matrix spike samples, which provide information about compound recoveries, were reported by Valder and others (2011).

Data from all source-water and quality-control samples collected by each SWQA were reviewed to evaluate potential bias (primarily systematic contamination) associated with sample collection, processing, transportation, and analysis. A review of all quality-control data as a whole along with the associated environmental data is important because the small number of samples collected in each study area generally is not adequate to characterize the full magnitude of potential bias. A larger dataset that covers the entire period of sample collection for SWQA studies provides greater insight to possible systematic errors that bias sample results (Carter and others, 2010).

Data for 11 AOCs were removed from this dataset because of systematic contamination, analytical variability, or because the compound was no longer analyzed. Phenol was detected frequently in field and laboratory blanks and at concentrations comparable to concentrations measured in environmental samples; thus, concentrations for phenol were removed from the dataset. Studies conducted by the NWQL (Mark Sandstrom, USGS National Water Quality Laboratory, oral commun., 2005) indicated that samples can be contaminated if $\mathrm{N}, \mathrm{N}$-diethyl-meta-toluamide (DEET) is used by sampling personnel. The frequent detection of DEET in field blanks caused uncertainty in the quality of DEET concentrations in environmental samples (Carter and others, 2010); thus, DEET was removed from the dataset. Three compounds - benzophenone, isophorone, and para-nonylphenol - were detected frequently in field blanks because of the presence of these compounds in the $\mathrm{pH}$ buffer (Trizma) obtained from the vendor. Because Trizma is only added to finished water samples containing free chlorine and not source-water samples, the quality of data for benzophenone, isophorone, and para-nonylphenol is not fully understood. Additionally, in the blank samples, concentrations were comparable to concentrations measured in environmental samples (Carter and others, 2010); thus, concentrations for benzophenone, isophorone, and para-nonylphenol were removed from the dataset. Laboratory analyses of bisphenol A and pentachlorophenol produced unreliable data starting in March 2005 (Dave Reppert, USGS National Water Quality Laboratory, written commun., 2010); thus, concentrations of bisphenol A and pentachlorophenol were removed from the dataset. Laboratory analysis of deethyldeisopropylatrazine, fonofos-oxygen analog, chlorothalonil, and 3-ketocarbofuran performed below the NWQL standards, and thus are no longer analyzed and were removed from the dataset.

For compounds detected in 50 percent or more of an individual SWQA's field blanks, all environmental and quality-control data for those compounds for that study area were removed from the dataset (Carter and others, 2010). After these concentrations were removed, compounds detected in 5 percent or more of all remaining field-blank samples were evaluated, and all detections of those compounds in environmental samples that were less than or equal to the highest blank concentration were censored by coding environmental concentrations with a " $\mathrm{C}<$ " and by changing the concentration value to the highest blank concentration. Compounds coded as " $\mathrm{C}<$ " were not included in any analyses herein. Data used in analyses are documented in Carter and others (2010).

\section{Human-Health Benchmarks Used for Screening- Level Assessments}

Where a river (surface water) was the source of the drinking water, individual and annual mean concentrations of regulated compounds were compared to MCLs (U.S. Environmental Protection Agency, 2006a), and annual mean concentrations of unregulated compounds - those without EPA MCLs - were compared to HBSLs (Toccalino, 2007; Toccalino and others, 2008), when available. In this study, annual mean concentrations were calculated for each compound for each site. At most sites, samples were collected for about a 12-month period, but in some cases, the sampling period was somewhat longer or shorter than 12 months. Results for all samples for a particular site were used for calculating the annual mean concentration, and a value of one-quarter of the LRL was used when a compound was not detected. For plotting purposes, the median concentrations of the annual mean river concentrations for each site were used for comparison to human-health benchmarks.

Where a supply well (groundwater) was the source of the drinking water, individual concentrations of compounds were compared to MCLs and HBSLs, when available. Comparisons to human-health benchmarks were used in this report to identify concentrations of potential human-health concern and to provide an initial perspective on the potential importance of the AOCs detected.

Of the 265 compounds monitored in this study, 37 compounds have an established EPA MCL (U.S. Environmental Protection Agency, 2006a) and 123 compounds have an HBSL (Toccalino and others, 2008). Health-Based Screening Levels have not been developed for the remaining 105 unregulated compounds because of insufficient toxicity information. Therefore, the potential human-health significance of these 105 compounds cannot be evaluated at this time (Toccalino and others, 2006).

Maximum Contaminant Levels are legally enforceable EPA drinking-water standards that set the maximum permissible level of a compound in water that is delivered by public 
water systems (U.S. Environmental Protection Agency, 2013a). Maximum Contaminant Levels are applicable only to finished-water samples in the regulatory framework; however, an assessment of source-water concentrations in relation to benchmarks provides an indication to water-resource managers and CWSs of potential concerns in the absence of factors such as water treatment and distribution. For rivers, the permissible level (MCL), depending on the compound, may be defined in terms of a single sample concentration or in terms of a time-weighted mean concentration (Toccalino, 2007).

Health-Based Screening Levels are benchmark concentrations of compounds in water that, if exceeded, may be of potential concern for human health. Health-Based Screening Levels are not regulatory standards, are not enforceable, and water systems are not required to monitor for any compounds for which HBSLs have been developed. Health-Based Screening Levels were developed collaboratively by the USGS, EPA, New Jersey Department of Environmental Protection, and Oregon Health and Science University (Toccalino and others, 2003). The HBSL values were developed using EPA Office of Water methodologies and EPA toxicity values, so they generally are comparable to EPA drinking-water guideline values such as Lifetime Health Advisory Levels and Risk Specific Level Concentrations (U.S. Environmental Protection Agency, 2012c). A $10^{-6}$ to $10^{-4}$ cancer risk level represents low and high HBSL values (Toccalino and others, 2008).

Concentrations of compounds in samples of source water were compared to human-health benchmarks as a screeninglevel assessment. This comparison identifies compounds with concentrations that approached or were greater than benchmarks to aid in assessing their potential relevance to human health. For these comparisons, benchmark quotient (BQ) values - the ratio of a concentration of a compound to its benchmark (MCL or HBSL) - were calculated. A BQ value greater than 1 represents a concentration greater than a benchmark. A BQ value greater than 0.1 can be used to identify compounds that may warrant additional monitoring (Toccalino and others, 2006). A threshold BQ of 0.1 (that is, one-tenth of the benchmark value) is consistent with various State and Federal practices (for example, U.S. Environmental Protection Agency, 1998). Monitoring for these compounds would enable analysis of trends in their occurrence and may provide an early indication if concentrations approach human-health benchmarks.

\section{Determination of Commonly Occurring Compounds}

Although samples were analyzed for 265 compounds monitored at all sites, emphasis is placed on those found to commonly occur in source water. Commonly occurring compounds are defined herein as those that were detected in greater than or equal to 1 percent of samples using an assessment level of $0.05 \mu \mathrm{g} / \mathrm{L}$ or when a compound was detected in greater than or equal to 10 percent of samples at no assessment level. By this definition, 71 compounds were identified in surface water (table 3 ). Of these 71 compounds, 16 had the same detection frequency with and without the application of a common assessment level of $0.05 \mu \mathrm{g} / \mathrm{L}$, such as tri(2-butoxyethyl)phosphate (table 3; appendix 2). These 16 compounds have a median LRL that is greater than $0.05 \mu \mathrm{g} / \mathrm{L}$, and all detected concentrations were greater than that concentration. The 71 compounds represent 12 of the 13 use group categories (table 2); the refrigerants and propellants group was the only use group with no detections (appendix 2).

Twenty-eight commonly occurring compounds were identified in groundwater. Of these 28 compounds, 3 had the same detection frequency with and without the application of a common assessment level of $0.05 \mu \mathrm{g} / \mathrm{L}$ (table 3; appendix 3 ) because the LRL for the 3 compounds is greater than $0.05 \mu \mathrm{g} / \mathrm{L}$. The 28 compounds represent seven use groups: disinfection by-products; gasoline hydrocarbons, oxygenates, and oxygenate degradates; herbicides and herbicide degradates; organic synthesis compounds; personal-care and domestic-use products; refrigerants and propellants; and solvents.

\section{Determination of Mixtures Used to Summarize Compound Co-Occurrence}

A mixture occurrence analysis for the AOCs was done using methods used by Squillace and others (2002); J.C. Scott (U.S. Geological Survey, written commun., March 2011); DeSimone (2009); and Toccalino and others (2010). These methods define "unique mixtures" as specific combinations of two or more compounds in a given sample, regardless of the presence or absence of additional compounds in the same sample. By this definition, any environmental sample with hundreds of analyte concentrations could have thousands of unique combinations of mixtures present.

\section{Characterization of Community Water Systems and Sites Sampled for Anthropogenic Organic Compounds}

Selected ancillary information was generated for CWSs throughout the conterminous United States and for the 20 river intakes and 448 CWS supply wells sampled by the USGS in this study to characterize sampled sites in a national context. An extract of the EPA Safe Drinking Water Information System (SDWIS) (U.S. Environmental Protection Agency, 2012b) was used to develop spatially derived and system-specific ancillary data. The SDWIS is a dataset that EPA aggregates from information submitted by the States. Before this study, the USGS, in cooperation with EPA, developed the Public Supply Database (PSDB) (U.S. Environmental Protection Agency, 2005; U.S. Environmental Protection Agency, 2012b; Curtis V. Price, U.S. Geological Survey, written commun., 2012), which integrates information available from active 
Table 3. Summary of commonly occurring compounds in surface water $(n=71)$ and groundwater $(n=28)$.

[CASRN, Chemical Abstracts Service Registry Number; MCPA, (4-chloro-2-methylphenoxy)-acetic acid; \%, percent; --, no information available; $\mu \mathrm{g} / \mathrm{L}$, micrograms per liter]

\begin{tabular}{|c|c|c|}
\hline CASRN $^{a}$ & Compound name & $\begin{array}{l}\text { Detection frequency criteria met to be considered a commonly } \\
\text { occurring compound }\end{array}$ \\
\hline \multicolumn{3}{|c|}{ Surface water } \\
\hline $95-63-6$ & 1,2,4-Trimethylbenzene & Detected in $1 \%$ or more of samples at an assessment level of $0.05 \mu \mathrm{g} / \mathrm{L}$. \\
\hline $106-46-7$ & 1,4-Dichlorobenzene ( $p$-dichlorobenzene) & Detected in $1 \%$ or more of samples at an assessment level of $0.05 \mu \mathrm{g} / \mathrm{L}$. \\
\hline $94-75-7$ & $2,4-\mathrm{D}$ & Detected in $1 \%$ or more of samples at an assessment level of $0.05 \mu \mathrm{g} / \mathrm{L}$. \\
\hline $95-76-1$ & 3,4-Dichloroaniline & Detected in $1 \%$ or more of samples at an assessment level of $0.05 \mu \mathrm{g} / \mathrm{L}$. \\
\hline $360-68-9$ & 3-beta-Coprostanol ${ }^{\mathrm{b}}$ & Detected in $1 \%$ or more of samples at an assessment level of $0.05 \mu \mathrm{g} / \mathrm{L}$. \\
\hline $136-85-6$ & 5-Methyl-1H-benzotriazole ${ }^{\mathrm{b}}$ & Detected in $1 \%$ or more of samples at an assessment level of $0.05 \mu \mathrm{g} / \mathrm{L}$. \\
\hline $34256-82-1$ & Acetochlor & Detected in $1 \%$ or more of samples at an assessment level of $0.05 \mu \mathrm{g} / \mathrm{L}$. \\
\hline $15972-60-8$ & Alachlor & $\begin{array}{l}\text { Detected in less than } 1 \% \text { of samples at an assessment level of } 0.05 \mu \mathrm{g} / \mathrm{L} \\
\text { but detected in more than } 10 \% \text { of samples at no assessment level. }\end{array}$ \\
\hline $84-65-1$ & Anthraquinone & Detected in $1 \%$ or more of samples at an assessment level of $0.05 \mu \mathrm{g} / \mathrm{L}$. \\
\hline $1912-24-9$ & Atrazine & Detected in $1 \%$ or more of samples at an assessment level of $0.05 \mu \mathrm{g} / \mathrm{L}$. \\
\hline $17804-35-2$ & Benomyl & Detected in $1 \%$ or more of samples at an assessment level of $0.05 \mu \mathrm{g} / \mathrm{L}$. \\
\hline $71-43-2$ & Benzene & Detected in $1 \%$ or more of samples at an assessment level of $0.05 \mu \mathrm{g} / \mathrm{L}$. \\
\hline $83-46-5$ & beta-Sitosterol $^{\mathrm{b}}$ & Detected in $1 \%$ or more of samples at an assessment level of $0.05 \mu \mathrm{g} / \mathrm{L}$. \\
\hline $19466-47-8$ & beta-Stigmastanol $^{\mathrm{b}}$ & Detected in $1 \%$ or more of samples at an assessment level of $0.05 \mu \mathrm{g} / \mathrm{L}$. \\
\hline $75-27-4$ & Bromodichloromethane & Detected in $1 \%$ or more of samples at an assessment level of $0.05 \mu \mathrm{g} / \mathrm{L}$. \\
\hline $90982-32-4$ & Chlorimuron-ethyl & Detected in $1 \%$ or more of samples at an assessment level of $0.05 \mu \mathrm{g} / \mathrm{L}$. \\
\hline $108-90-7$ & Chlorobenzene & Detected in $1 \%$ or more of samples at an assessment level of $0.05 \mu \mathrm{g} / \mathrm{L}$. \\
\hline $67-66-3$ & Chloroform & Detected in $1 \%$ or more of samples at an assessment level of $0.05 \mu \mathrm{g} / \mathrm{L}$. \\
\hline $57-88-5$ & Cholesterol $^{\mathrm{b}}$ & Detected in $1 \%$ or more of samples at an assessment level of $0.05 \mu \mathrm{g} / \mathrm{L}$. \\
\hline $156-59-2$ & cis-1,2-Dichloroethene & Detected in $1 \%$ or more of samples at an assessment level of $0.05 \mu \mathrm{g} / \mathrm{L}$. \\
\hline $486-56-6$ & Cotinine & Detected in $1 \%$ or more of samples at an assessment level of $0.05 \mu \mathrm{g} / \mathrm{L}$. \\
\hline $6190-65-4$ & Deethylatrazine & Detected in $1 \%$ or more of samples at an assessment level of $0.05 \mu \mathrm{g} / \mathrm{L}$. \\
\hline $1007-28-9$ & Deisopropylatrazine & Detected in $1 \%$ or more of samples at an assessment level of $0.05 \mu \mathrm{g} / \mathrm{L}$. \\
\hline-- & Desulfinylfipronil & $\begin{array}{l}\text { Detected in less than } 1 \% \text { of samples at an assessment level of } 0.05 \mu \mathrm{g} / \mathrm{L} \\
\text { but detected in more than } 10 \% \text { of samples at no assessment level. }\end{array}$ \\
\hline $333-41-5$ & Diazinon & $\begin{array}{l}\text { Detected in less than } 1 \% \text { of samples at an assessment level of } 0.05 \mu \mathrm{g} / \mathrm{L} \\
\text { but detected in more than } 10 \% \text { of samples at no assessment level. }\end{array}$ \\
\hline $124-48-1$ & Dibromochloromethane ${ }^{b}$ & Detected in $1 \%$ or more of samples at an assessment level of $0.05 \mu \mathrm{g} / \mathrm{L}$. \\
\hline $1918-00-9$ & Dicamba & Detected in $1 \%$ or more of samples at an assessment level of $0.05 \mu \mathrm{g} / \mathrm{L}$. \\
\hline $330-54-1$ & Diuron & Detected in $1 \%$ or more of samples at an assessment level of $0.05 \mu \mathrm{g} / \mathrm{L}$. \\
\hline
\end{tabular}


Table 3. Summary of commonly occurring compounds in surface water ( $n=71)$ and groundwater $(n=28)$.-Continued

[CASRN, Chemical Abstracts Service Registry Number; MCPA, (4-Chloro-2-methylphenoxy)-acetic acid; \%, percent; --, no information available; $\mu \mathrm{g} / \mathrm{L}$, micrograms per liter]

\begin{tabular}{|c|c|c|}
\hline CASRN $^{a}$ & Compound name & $\begin{array}{l}\text { Detection frequency criteria met to be considered a commonly } \\
\text { occurring compound }\end{array}$ \\
\hline $100-41-4$ & Ethylbenzene & Detected in $1 \%$ or more of samples at an assessment level of $0.05 \mu \mathrm{g} / \mathrm{L}$. \\
\hline $120068-37-3$ & Fipronil & $\begin{array}{l}\text { Detected in less than } 1 \% \text { of samples at an assessment level of } 0.05 \mu \mathrm{g} / \mathrm{L} \\
\text { but detected in more than } 10 \% \text { of samples at no assessment level. }\end{array}$ \\
\hline $120067-83-6$ & Fipronil sulfide & $\begin{array}{l}\text { Detected in less than } 1 \% \text { of samples at an assessment level of } 0.05 \mu \mathrm{g} / \mathrm{L} \\
\text { but detected in more than } 10 \% \text { of samples at no assessment level. }\end{array}$ \\
\hline $1222-05-5$ & $\begin{array}{l}\text { Hexahydrohexamethyl-cyclopentabenzopyran } \\
\text { (HHCB) }\end{array}$ & Detected in $1 \%$ or more of samples at an assessment level of $0.05 \mu \mathrm{g} / \mathrm{L}$. \\
\hline $51235-04-2$ & Hexazinone & $\begin{array}{l}\text { Detected in less than } 1 \% \text { of samples at an assessment level of } 0.05 \mu \mathrm{g} / \mathrm{L} \\
\text { but detected in more than } 10 \% \text { of samples at no assessment level. }\end{array}$ \\
\hline $94-74-6$ & MCPA & Detected in $1 \%$ or more of samples at an assessment level of $0.05 \mu \mathrm{g} / \mathrm{L}$. \\
\hline $1634-04-4$ & Methyl tert-butyl ether (MTBE) & Detected in $1 \%$ or more of samples at an assessment level of $0.05 \mu \mathrm{g} / \mathrm{L}$. \\
\hline $75-09-2$ & Methylene chloride & Detected in $1 \%$ or more of samples at an assessment level of $0.05 \mu \mathrm{g} / \mathrm{L}$. \\
\hline $51218-45-2$ & Metolachlor & Detected in $1 \%$ or more of samples at an assessment level of $0.05 \mu \mathrm{g} / \mathrm{L}$. \\
\hline $74223-64-6$ & Metsulfuron methyl $l^{b}$ & Detected in $1 \%$ or more of samples at an assessment level of $0.05 \mu \mathrm{g} / \mathrm{L}$. \\
\hline $91-20-3$ & Naphthalene ${ }^{\mathrm{b}}$ & Detected in $1 \%$ or more of samples at an assessment level of $0.05 \mu \mathrm{g} / \mathrm{L}$. \\
\hline $26027-38-2$ & Nonylphenol, diethoxy- (total) ${ }^{\mathrm{b}}$ & Detected in $1 \%$ or more of samples at an assessment level of $0.05 \mu \mathrm{g} / \mathrm{L}$. \\
\hline $\begin{array}{l}2315-61-9 / \\
51437-90-2\end{array}$ & Octylphenol, diethoxy- (OPEO2) & Detected in $1 \%$ or more of samples at an assessment level of $0.05 \mu \mathrm{g} / \mathrm{L}$. \\
\hline $709-98-8$ & Propanil & Detected in $1 \%$ or more of samples at an assessment level of $0.05 \mu \mathrm{g} / \mathrm{L}$. \\
\hline $122-34-9$ & Simazine & Detected in $1 \%$ or more of samples at an assessment level of $0.05 \mu \mathrm{g} / \mathrm{L}$. \\
\hline $5915-41-3$ & Terbuthylazine & $\begin{array}{l}\text { Detected in less than } 1 \% \text { of samples at an assessment level of } 0.05 \mu \mathrm{g} / \mathrm{L} \\
\text { but detected in more than } 10 \% \text { of samples at no assessment level. }\end{array}$ \\
\hline $994-05-8$ & tert-Amyl methyl ether (TAME) & Detected in $1 \%$ or more of samples at an assessment level of $0.05 \mu \mathrm{g} / \mathrm{L}$. \\
\hline $75-65-0$ & tert-Butyl alcohol ${ }^{\mathrm{b}}$ & Detected in $1 \%$ or more of samples at an assessment level of $0.05 \mu \mathrm{g} / \mathrm{L}$. \\
\hline $109-99-9$ & Tetrahydrofuran (1,4-epoxybutane $)^{\mathrm{b}}$ & Detected in $1 \%$ or more of samples at an assessment level of $0.05 \mu \mathrm{g} / \mathrm{L}$. \\
\hline $108-88-3$ & Toluene & Detected in $1 \%$ or more of samples at an assessment level of $0.05 \mu \mathrm{g} / \mathrm{L}$. \\
\hline $78-51-3$ & Tri(2-butoxyethyl)phosphate ${ }^{b}$ & Detected in $1 \%$ or more of samples at an assessment level of $0.05 \mu \mathrm{g} / \mathrm{L}$. \\
\hline $115-96-8$ & Tri(2-chloroethyl)phosphate ${ }^{\mathrm{b}}$ & Detected in $1 \%$ or more of samples at an assessment level of $0.05 \mu \mathrm{g} / \mathrm{L}$. \\
\hline $79-01-6$ & Trichloroethene (TCE) & Detected in $1 \%$ or more of samples at an assessment level of $0.05 \mu \mathrm{g} / \mathrm{L}$. \\
\hline $55335-06-3$ & Triclopyr & Detected in $1 \%$ or more of samples at an assessment level of $0.05 \mu \mathrm{g} / \mathrm{L}$. \\
\hline $3380-34-5$ & Triclosan & Detected in $1 \%$ or more of samples at an assessment level of $0.05 \mu \mathrm{g} / \mathrm{L}$. \\
\hline
\end{tabular}


Table 3. Summary of commonly occurring compounds in surface water $(n=71)$ and groundwater $(n=28)$. - Continued

[CASRN, Chemical Abstracts Service Registry Number; MCPA, (4-Chloro-2-methylphenoxy)-acetic acid; \%, percent; --, no information available; $\mu \mathrm{g} / \mathrm{L}$, micrograms per liter]

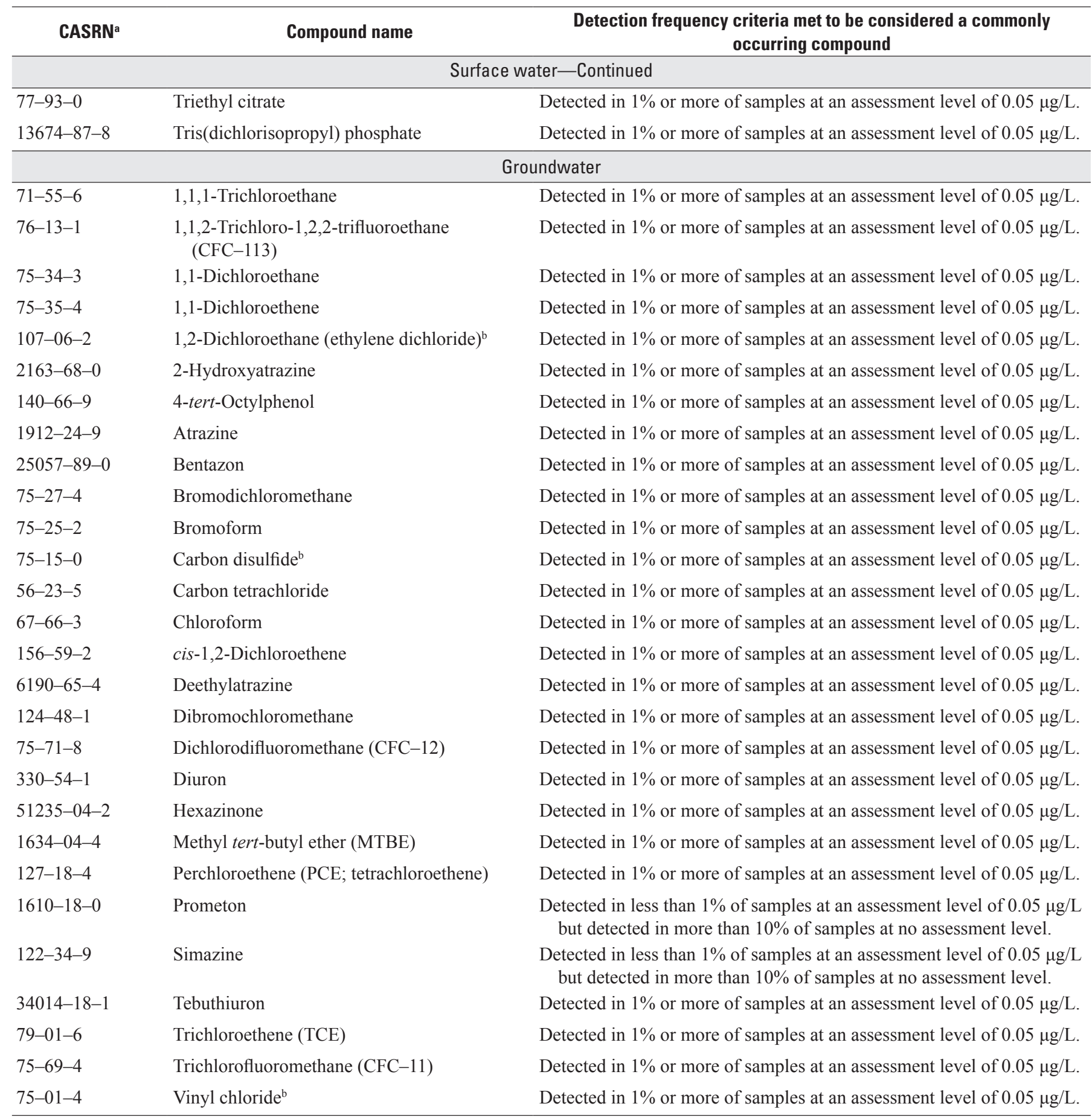

${ }^{a}$ This report contains Chemical Abstracts Service Registry Numbers (CASRN) ${ }^{\circledR}$, which is a Registered Trademark of the American Chemical Society. The CASRN online database provides the latest registry number information: http://www.cas.org/. Chemical Abstracts Service recommends the verification of the CASRNs through CAS Client Services ${ }^{\mathrm{SM}}$.

${ }^{b}$ Compunds have the same detection frequency with and without an assessment level of $0.05 \mu \mathrm{g} / \mathrm{L}$. 
systems and facilities in SDWIS with matched data stored in the USGS National Water Information System (NWIS). The PSDB includes a large list of 11,400 surface-water intakes and 144,232 supply wells. Many of these records represent SDWIS sites that are now inactive or destroyed, or represent other types of facilities such as conveyances (deliveries between water systems).

Surface-water intake locations were supplied to EPA to develop watershed polygons. These watershed polygons were, in turn, provided to USGS for verification. A detailed check of these watersheds yielded a set of 4,831 unique intake watersheds determined to have accurate delineations (Michael E. Wieczorek, U.S. Geological Survey, written commun., 2012). Of these unique intake watersheds, 2,016 were determined to represent intake locations on rivers, based on the facility name and whether the intake was included in the National Inventory of Dams to exclude lakes and reservoirs (Alexander and others, 1999). Of the 144,232 supply wells, a total of 112,099 wells were determined to be active CWS wells with valid latitude-longitude locations. These wells were buffered with a 500-meter (m) radius to create circular groundwater contributing area polygons surrounding each well. These 2,016 watersheds and 112,099 contributing areas are considered to represent the national population of river and supply well sites, respectively, supplying CWSs. Ancillary variables were characterized within their boundaries using the NAWQA AreaCharacterization Toolbox (Price and others, 2010). Ancillary variables include population served, basin size, land use, population density, and recharge (table 4).

Overall, the source waters sampled as part of this study represent about 1 percent of all CWS river intakes and 0.4 percent of all CWS supply wells in the conterminous United States (fig. 1). Although comparatively few sites were sampled relative to the national population of sites, comparison of ancillary variables for sampled sites generally covered the range of the total distribution of the national population with the exception of population served and watershed size for river intakes.

The national distribution of population served for CWSs associated with the 2,016 river intakes as well as the population served for CWSs supplied by the 20 sampled intakes is shown on figure 2 . Fifty percent of all systems serve a population greater than 5,900 persons. When comparing this to 20 sampled river intakes, 19 CWSs served more than 12,000 persons. This is a reflection of the study design, which specifically targeted larger CWSs for sampling. Similarly, comparing watershed size of sampled sites to the national distribution reveals that rivers with some of the largest watersheds were sampled (fig. $3 A$ ). This may be an artifact of targeting large CWSs serving populations near large rivers, which have large watersheds. The median watershed size of all 2,016 river intakes was 330.1 square kilometers $\left(\mathrm{km}^{2}\right)$. Nineteen of the 20 sampled river intakes had a watershed size greater than $1,000 \mathrm{~km}^{2}$; one river intake had a watershed size less than $10 \mathrm{~km}^{2}$ (fig. $3 A$ ).

The surface-water and groundwater sites were characterized by the dominant type of land use within each watershed for river intakes and for contributing areas around each supply well (table 5). To put results from this study into context with the national distribution of river intakes and supply wells used by CWS, all of the sites were grouped into a national population of land-use quartiles. Three of the land-use categories within each of the 20 watersheds were compared to the total distribution of the national population. Urban, agricultural, and undeveloped land use within the 20 watersheds generally covered the range of the total distribution of the national population (fig. $3 B, C$, and $D$, respectively). Similarly, population density and recharge for the 20 watersheds reasonably cover the range of the national distribution (fig. $3 E$ and $F$, respectively).

Comparison of ancillary variables for the contributing areas around the 448 supply wells, including population served, population density, urban and agricultural land use, and recharge, fully covered the range of the total distribution of the national population of 112,099 supply wells (figs. 4 and 5). The covered range of ancillary variables in these contributing areas may be more evenly distributed across the national distribution, in part, because of the larger number of wells sampled in comparison to the number of river intakes sampled.

Although this study was not designed as a comprehensive national-scale assessment of water supplying CWSs, the sites selected are considered to be representative of most systems in the Nation, with the exception of rivers supplying CWSs that serve small populations (less than 10,000) and that have a small watershed size (less than $1,000 \mathrm{~km}^{2}$ ). Overall, ancillary variables for watersheds of river intakes and for contributing areas of supply wells covered the range of the total distribution of the national population favorably. Although the number of river intakes and supply wells sampled is much smaller than the national dataset, observed patterns in water quality related to ancillary variables may still allow inferences to nonsampled river intakes and wells with similar ancillary conditions. Observed patterns in water quality related to ancillary factors may be used to estimate the number of nonsampled river intakes and supply wells with similar characteristics. For example, quartiles from the national population of ancillary data can be determined and sampled sites can be evaluated within each of the quartiles. Because the sampled sites are considered to represent the national population, water-quality determinations within each quartile may be used to infer the total number of nonsampled CWS sites within each quartile that may have similar ancillary conditions. 


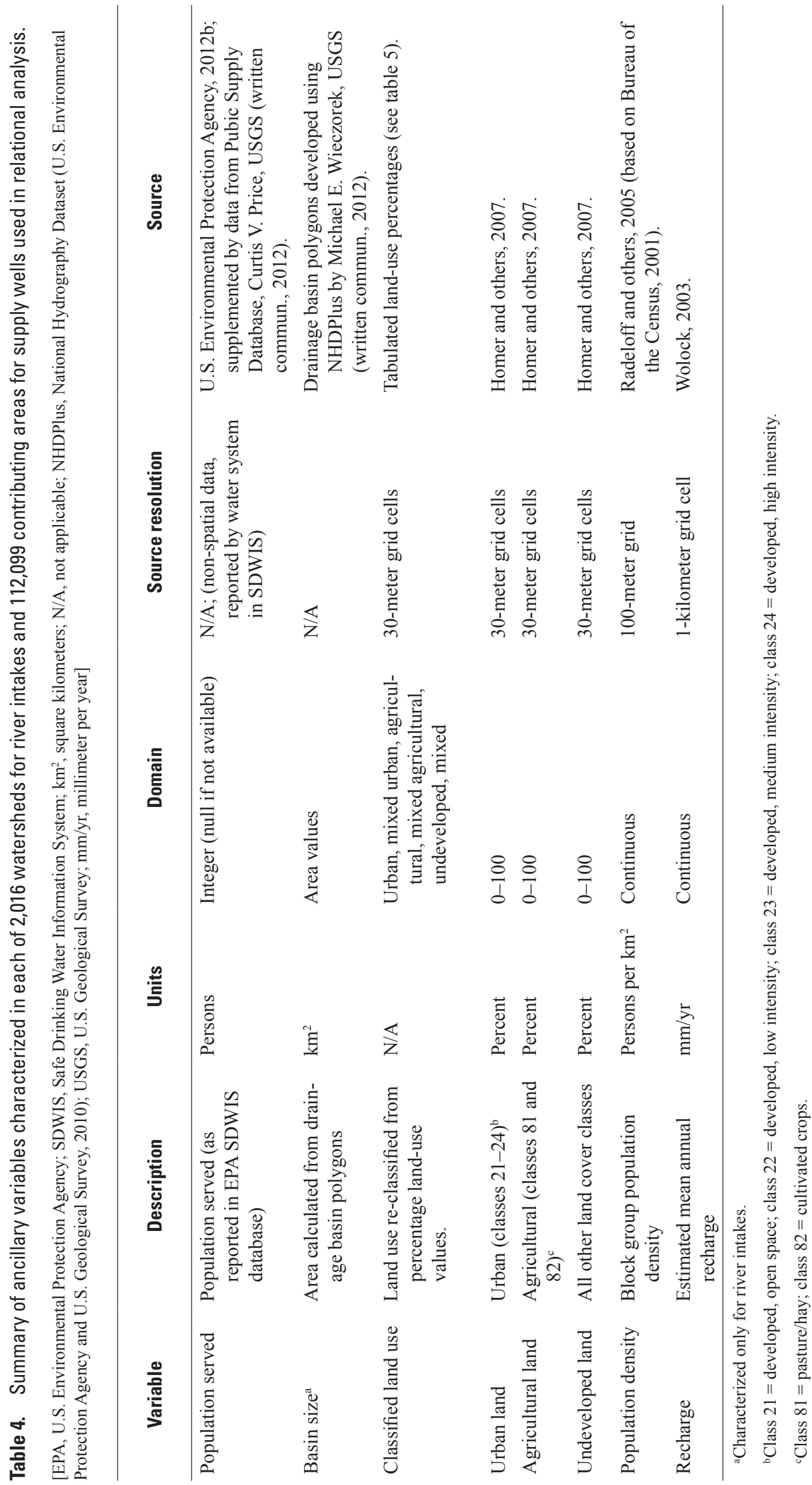




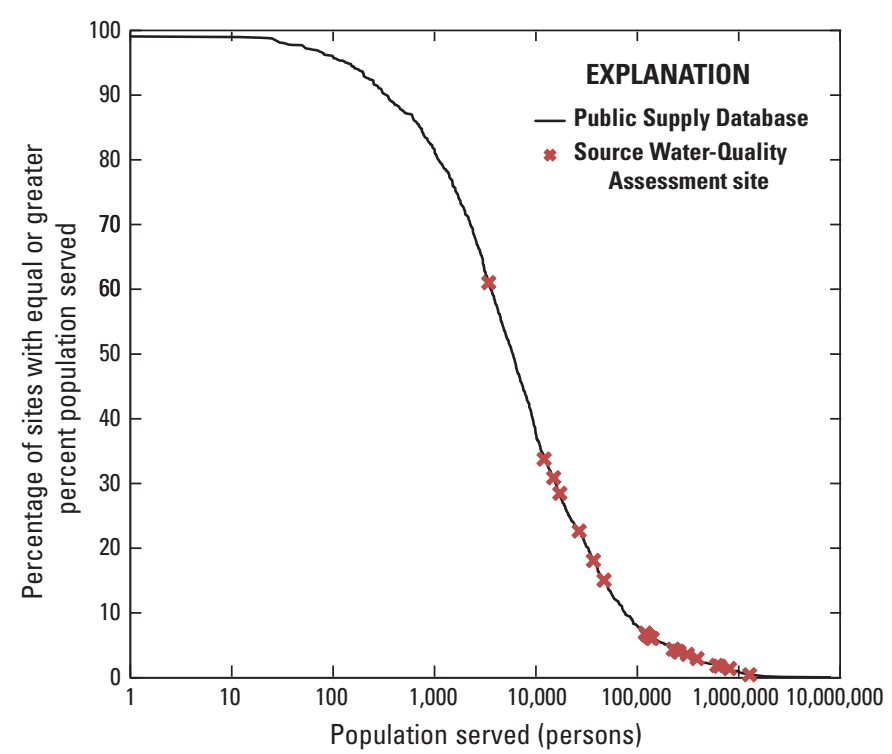

Figure 2. Distribution of population served for community water systems supplied by 2,016 river intakes in the conterminous United States compared to sampled river intakes.

\section{Occurrence of Anthropogenic Organic Compounds in Source Waters}

Surface-water and groundwater samples collected at all river intakes and supply wells, respectively, were analyzed for 265 AOCs; however, emphasis is placed on those detected commonly in source water. An additional 3 herbicides and 16 herbicide degradates were studied at a subset of sites where these compounds likely have been used. Because the additional compounds were not monitored at all of the sites, they are described separately from the most commonly occurring compounds that were monitored at all sites. Between the years of 2002 through 2010, 16 surface-water samples at river intakes were collected over the course of a year and groundwater samples were collected once from each supply well during 2002-09. A total of 313 samples were collected from 20 river intakes and 448 groundwater samples were collected for 30 individual SWQA studies around the country.

Compound occurrence is summarized in four sections: (1) occurrence in surface water; (2) occurrence in groundwater; (3) comparison of occurrence between surface-water and groundwater; and (4) additional herbicides and herbicide degradates. In general, the characterization of occurrence focuses on the most frequently occurring compounds (table 3) with and without an assessment level, comparison of concentrations to human-health benchmarks, factors that may affect occurrence, and unique mixtures that frequently co-occur in samples.
Compound occurrence was determined with and without an assessment level. An assessment level of $0.05 \mu \mathrm{g} / \mathrm{L}$ was used herein to compare detection frequencies for individual compounds with different LRLs. Detection frequency depends on the LRL for each compound monitored. Thus, different detection frequencies for compounds with different LRLs may not represent true differences in water quality, but rather may only reflect differences in analytical sensitivity among the different compounds. Therefore, one approach to characterizing compound occurrence was the use of a common assessment level. Conversely, using no assessment level emphasizes the significance of low-level concentrations at which many of these compounds were detected. Detections of AOCs do not necessarily indicate a concern to human health but rather help to identify emerging issues and are useful to track changes in occurrence and concentrations through time. The frequency of detection for all $265 \mathrm{AOCs}$ and the additional 19 herbicides and herbicide degradates for surface water and groundwater are summarized in appendixes 2 and 3, respectively, and the concentration data for the detected compounds are shown in appendixes 4 and 5, respectively.

Comparing source-water concentrations to humanhealth benchmarks helps to provide (1) some context for the results relative to human health and (2) some insight into which compounds merit additional study or monitoring. Although MCLs and HBSLs are not directly applicable to source-water samples, comparing concentrations of compounds in source water to human-health benchmarks is important because many of the compounds monitored may not be removed by water treatment processes unless specifically designed for their removal. In samples collected from rivers, both the individual concentrations and the annual mean concentrations for all compounds with a human-health benchmark were evaluated.

Occurrence information was further evaluated with respect to various ancillary factors, which may provide an improved understanding of compound occurrence. Ancillary factors included, in part, land use, population density, and population served. When applicable, additional ancillary factors specific to rivers and supply wells also were used in interpreting the occurrence of compounds found in samples.

A total of 313 and 448 rivers and groundwater samples, respectively, were included in the mixture analyses. Mixtures were examined in three categories: (1) an overall assessment of mixtures present in samples (that is, the number of compounds present in samples), (2) unique mixtures of specific compounds with an assessment level applied to the concentrations, and (3) unique mixtures of specific compounds without an assessment level. Because of the enormous (several million) number of combinations of unique mixtures of compounds in any given sample using no assessment level, only the 10 most frequently occurring mixture combinations are presented in this report. 

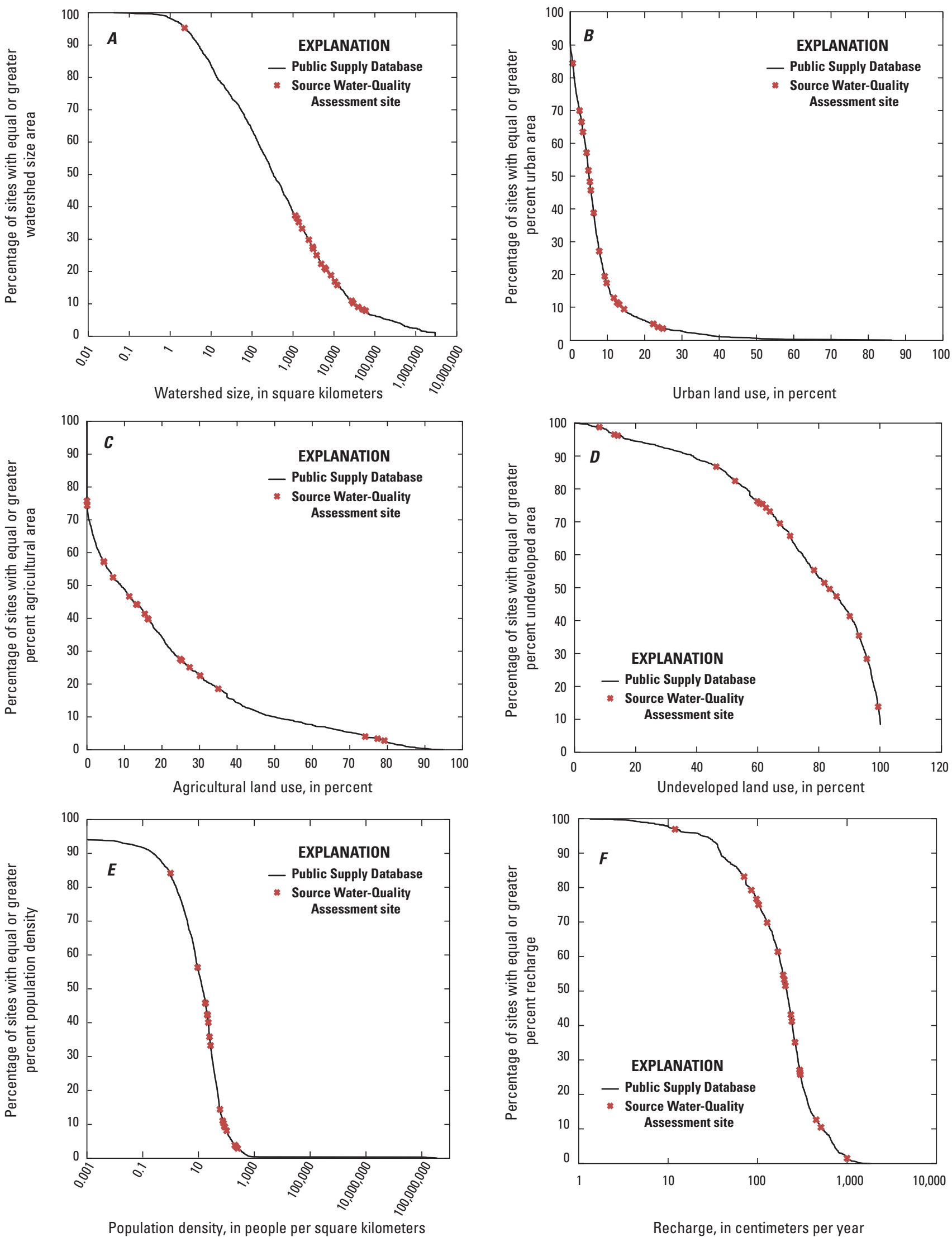

Figure 3. Distribution of 2,016 river intakes compared to sampled river intakes. $A$, watershed size; $B$, urban land use within watershed; $C$, agricultural land use within watershed; $D$, undeveloped land use within watershed; $E$, population density within watershed; and $F$, recharge within watershed (modified from Wolock, 2003). 
Table 5. Land-use classification (modified from Gilliom and others, 2006).

$[>$, greater than; $\leq$, less than or equal to; $<$, less than $]$

\begin{tabular}{ll}
\hline $\begin{array}{c}\text { Land-use } \\
\text { classification }\end{array}$ & Watershed land-use criteria \\
\hline Agricultural (ag) & $>50$ percent "ag" and $\leq 5$ percent "ur" \\
Urban (ur) & $>25$ percent "ur" and $\leq 25$ percent "ag" \\
Undeveloped (un) & $<5$ percent "ur" and $\leq 25$ percent "ag" \\
Mixed & $\begin{array}{l}\text { All other combinations of "ur","ag", and "un" } \\
\text { Ur mixed }\end{array}$ \\
"Mixed" (as above) and percent "ur" $>20$ \\
$\begin{array}{c}\text { Ag mixed } \\
\text { "Mixed" (as above) and percent "ag" }>50 \\
\text { and percent "ur" }<10\end{array}$
\end{tabular}

\section{Commonly Occurring Anthropogenic Organic Compounds in Surface Water}

Ninety-eight (about 37 percent) of the 265 AOCs monitored at all sites were detected in one or more surfacewater samples, and $167 \mathrm{AOCs}$ (about 63 percent) were never detected using an assessment level of $0.05 \mu \mathrm{g} / \mathrm{L}$ (appendix 2). An assessment level $(0.05 \mu \mathrm{g} / \mathrm{L}$ used herein) is necessary to compare detection frequencies of one compound to another because of the differing LRLs among compounds and through time. Commonly occurring compounds are defined as those that were detected in greater than or equal to 1 percent of samples using an assessment level of $0.05 \mu \mathrm{g} / \mathrm{L}$ or those compounds detected in greater than or equal to 10 percent of samples without an assessment level. This section focuses on compound occurrence in surface water. Concentrations are evaluated in more detail in the "Comparison of Surface-Water and Groundwater Occurrence" section.

Seventy-one compounds were found to commonly occur, as defined previously, in surface-water samples (fig. 6). Using the assessment level, 15 compounds were detected in more than 10 percent of samples. Of these 15 compounds, six were detected in 20 percent or more of samples: hexahydrohexamethylcyclopentabenzopyran (HHCB) (29.5 percent), chloroform (27.3 percent), atrazine (27.3 percent), tri(2-butoxyethyl) phosphate (23.8 percent), methyl tert-butyl ether (MTBE) (20.9 percent), and 2,4-D (20.4 percent). The most commonly occurring compound, HHCB, is commonly used in detergents and other personal-care products and has been found in both influent and effluent of wastewater-treatment plants in the United States and Europe (Bester, 2004; Phillips and others, 2005). Hexahydrohexamethylcyclopentabenzopyran is a synthetic musk fragrance used in items such as decorative cosmetics, shampoos, toilet soaps, household cleaners, and detergents (Api and Ford, 1999). Three of the most commonly occurring compounds- $\mathrm{HHCB}$, chloroform, and tri(2-butoxyethyl)phosphate- have been linked to influent and effluent of municipal and industrial wastewater discharge (Bester, 2004; Phillips and others, 2005; Ivahnenko and Barbash, 2004; Kolpin and others, 2002; Kingsbury and others, 2008). This highlights the importance of understanding discharges from wastewater-treatment plants and septic systems to surface waters used as a source of supply for CWSs. Atrazine, MTBE, and 2,4-D have each been linked to overland runoff and releases from leaking underground storage tanks (Gilliom and others, 2006; Zogorski and others, 2006; Rowe and others, 2007).

A wide variety of compounds were detected in surfacewater samples. Compounds from 12 of the 13 use groups were found to commonly occur indicating that a wide variety of sources and pathways exist for these compounds to reach the rivers sampled. No compounds in the refrigerants and propellants group were detected in any surface-water samples. Compounds in the herbicides and herbicide degradates group were among the most commonly detected compounds followed by the gasoline hydrocarbons, oxygenates, and oxygenate degradates group and the personal-care and domestic-use products group (fig. 6).

Of the 71 commonly occurring compounds in surfacewater samples, 22 compounds were herbicides and herbicide degradates. Their frequent detection is due to their widespread use compared to other compounds and may be an artifact of the larger number of herbicides analyzed in samples in comparison to other compounds. Previous studies indicate that herbicide degradates typically occur with their parent compounds at concentrations similar to or greater than concentrations of their parent compounds (Thurman and others, 1992; Kalkhoff and others, 1998; Gilliom and others, 2006). For many degradates, little is known about their occurrence or their effects on human health. With a few exceptions for herbicides and

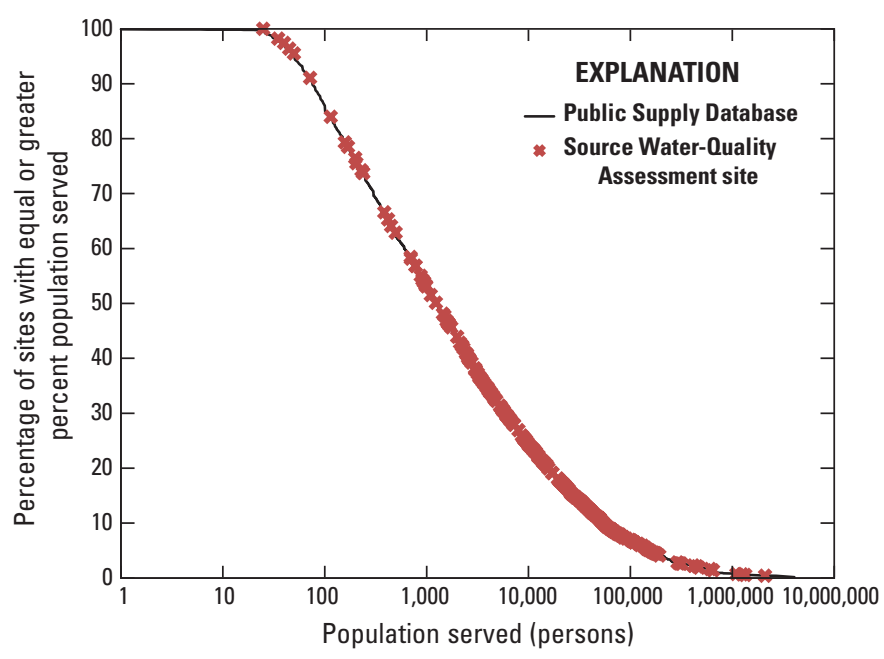

Figure 4. Distribution of population served for community water systems supplied by 112,099 supply wells in the conterminous United States compared to sampled supply wells. 

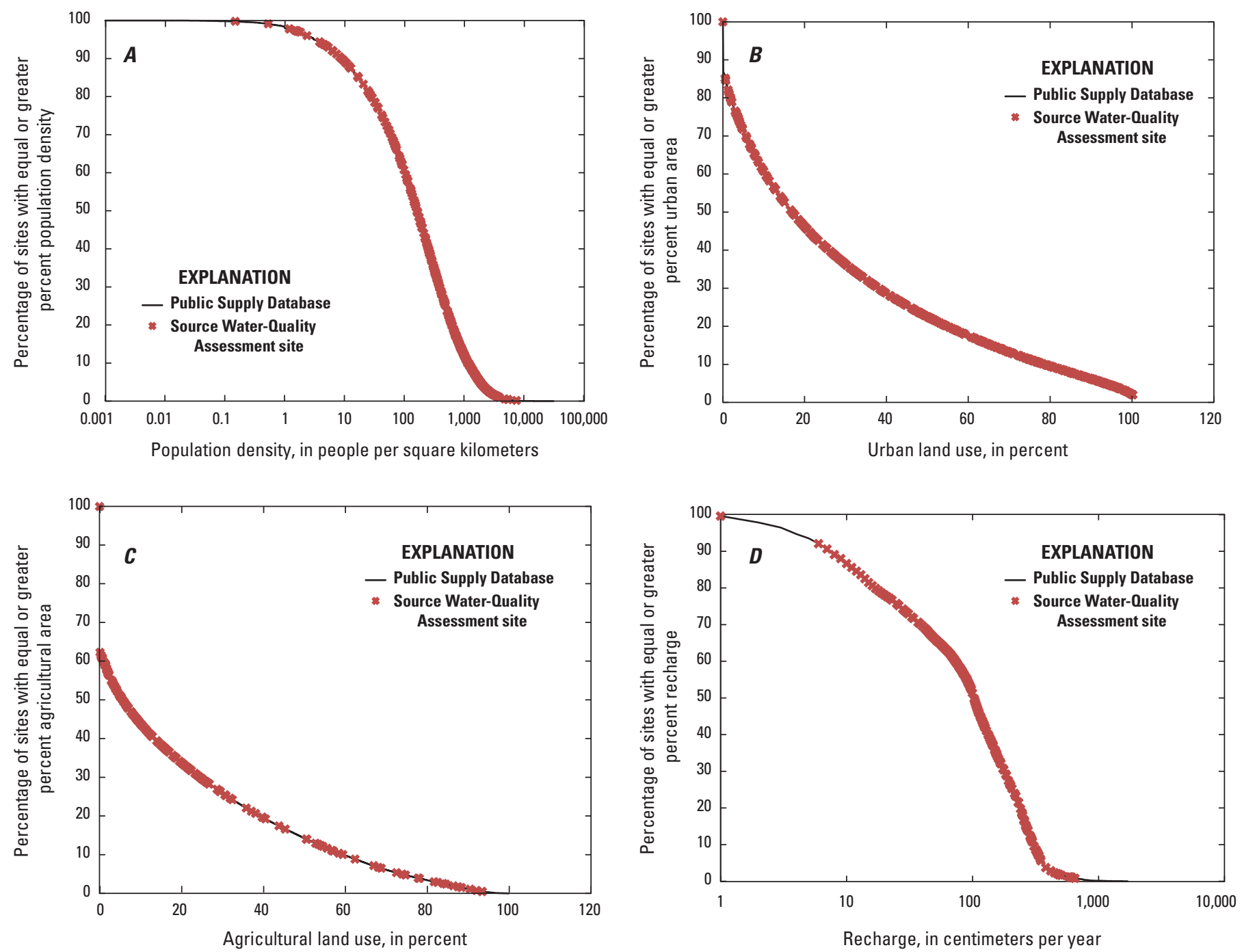

Figure 5. Distribution of 112,099 supply wells compared to sampled supply wells. $A$, population density within contributing area; $B$, urban land use within contributing area; $C$, agricultural land use within contributing area; and $D$, recharge within contributing area (modified from Wolock, 2003).

degradates with known common modes of action, drinkingwater standards or human-health benchmarks are not available for most herbicide degradates. Several herbicide degradates, principally those of atrazine and 3,4-dichloroaniline (a degradate of diuron), were detected. Atrazine was the most frequently detected herbicide, detected in 27.3 percent of the samples at an assessment level of $0.05 \mu \mathrm{g} / \mathrm{L}$. Atrazine was detected in 69.7 percent of samples without an assessment level with concentrations ranging from 0.002 to $20.1 \mu \mathrm{g} / \mathrm{L}$ and a median concentration of $0.03 \mu \mathrm{g} / \mathrm{L}$.

Ten gasoline hydrocarbons, oxygenates, and oxygenate degradates commonly occurred in surface-water samples. These compounds may be contributed to surface water from groundwater discharge, runoff from roads and parking lots, and watercraft that are used on these rivers or upstream reservoirs (Zogorski and others, 2006). Using an assessment level, MTBE was the most frequently detected compound in this use group (20.9 percent). Methyl tert-butyl ether is a gasoline oxygenate first introduced in 1979 to replace lead as an octane enhancer (U.S. Environmental Protection Agency, 2013b). Methyl tert-butyl ether has been detected in drinkingwater supplies throughout the country in previously published studies (Zogorski and others, 2006; Carter and others, 2006; U.S. Environmental Protection Agency, 2008b). Methyl tertbutyl ether was detected in 24.3 percent of samples without an assessment level with concentrations ranging from 0.03 to $3.4 \mu \mathrm{g} / \mathrm{L}$ and a median concentration of $0.12 \mu \mathrm{g} / \mathrm{L}$. The maximum concentration was detected in only one sample at one site. The second highest concentration detected was $0.7 \mu \mathrm{g} / \mathrm{L}$ at the same site.

Ten personal-care and domestic-use products commonly occurred. Hexahydrohexamethylcyclopentabenzopyran was the most frequently detected personal-care and domestic-use product (29.5 percent) using an assessment level, followed by caffeine (12.4 percent); nonylphenol, diethoxy- (total) (10.4 percent); and acetyl hexamethyl tetrahydronaphthalene 


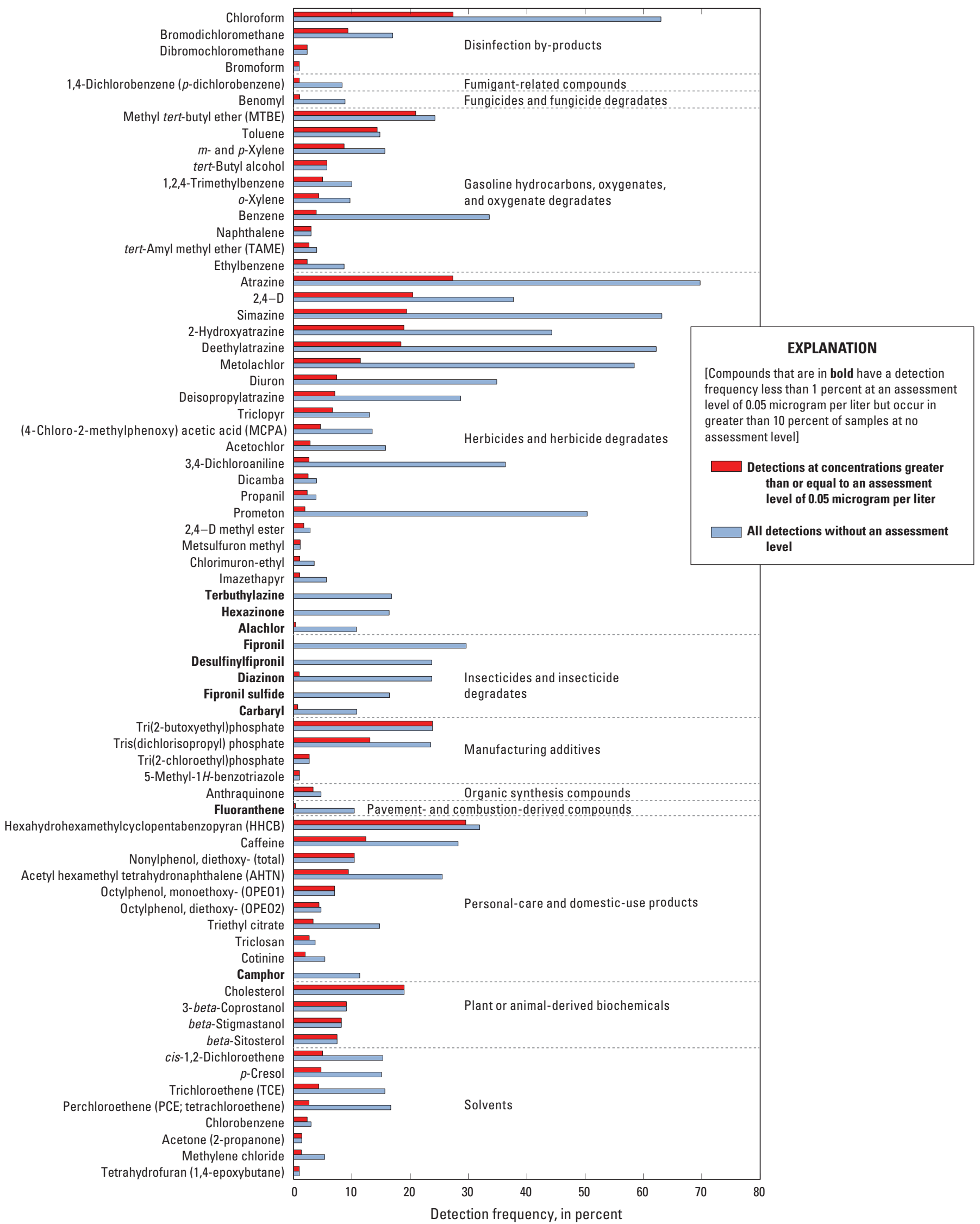

Figure 6. Commonly occurring compounds in source water derived from surface water. 
(AHTN) (9.4 percent). Hexahydrohexamethylcyclopentabenzopyran was detected in 31.9 percent of samples without an assessment level with concentrations ranging from 0.05 to $0.26 \mu \mathrm{g} / \mathrm{L}$ and a median concentration of $0.08 \mu \mathrm{g} / \mathrm{L}$. Caffeine was detected in 28.2 percent of samples without an assessment level with concentrations ranging from 0.01 to $0.28 \mu \mathrm{g} / \mathrm{L}$ and a median concentration of $0.05 \mu \mathrm{g} / \mathrm{L}$. Nonylphenol, diethoxy(total) was detected in 10.4 percent of samples without an assessment level with concentrations ranging from 0.47 to $6.6 \mu \mathrm{g} / \mathrm{L}$ and a median concentration of $1.7 \mu \mathrm{g} / \mathrm{L}$. Acetyl hexamethyl tetrahydronaphthalene was detected in 25.5 percent of samples without an assessment level with concentrations ranging from 0.005 to $0.15 \mu \mathrm{g} / \mathrm{L}$ and a median concentration of $0.04 \mu \mathrm{g} / \mathrm{L}$. Previously published studies have indicated that personal-care products may be introduced to rivers from treated wastewater discharge (Kingsbury and others, 2008).

Four of the 71 commonly occurring compounds were on the CCL3 (U.S. Environmental Protection Agency, 2012a): acetochlor, diuron, MTBE (described previously), and metolachlor. Acetochlor was detected in 15.8 percent of samples without an assessment level with concentrations ranging from 0.003 to $4.32 \mu \mathrm{g} / \mathrm{L}$ and a median concentration of $0.012 \mu \mathrm{g} / \mathrm{L}$. Diuron was detected in 34.9 percent of samples without an assessment level with concentrations ranging from 0.002 to $0.47 \mu \mathrm{g} / \mathrm{L}$ and a median concentration of $0.024 \mu \mathrm{g} / \mathrm{L}$. Metolachlor was detected in 58.4 percent of samples without an assessment level with concentrations ranging from 0.002 to $2.93 \mu \mathrm{g} / \mathrm{L}$ and a median concentration of $0.012 \mu \mathrm{g} / \mathrm{L}$. The frequent occurrence of these compounds in surface-water samples may warrant consideration for future monitoring and possible consideration by other Federal and State programs.

\section{Commonly Occurring Anthropogenic Organic Compounds in Groundwater}

Ninety-three (about 35 percent) of the 265 AOCs monitored were detected in one or more groundwater samples, and 172 AOCs (about 65 percent) were never detected using an assessment level (appendix 3). Twenty-eight compounds were found to commonly occur in groundwater samples (fig. 7). Using the assessment level of $0.05 \mu \mathrm{g} / \mathrm{L}$, three compounds were detected in more than 10 percent of samples. Of these three compounds, chloroform was the most commonly occurring compound (23.9 percent) followed by MTBE (12.3 percent) and perchloroethene (PCE; 11.6 percent). Potential sources of chloroform to groundwater include chlorinated water or wastewater that has recharged the aquifer through leaking drinking-water distribution and sewer pipes or from irrigation of athletic fields, lawns, gardens, golf courses, and parks (Ivahnenko and Zogorski, 2006; Zogorski and others, 2006); and septic system effluent (DeWalle and others, 1985; Carter and others, 2012). Potential sources of MTBE include leaking storage tanks, urban storm runoff, leaking watercraft tanks, and used motor oils (Zogorski and others, 2006). Perchloroethene is a chlorinated solvent used in commercial dry cleaning and household degreasers (Zogorski and others, 2006). Chloroform, MTBE, and PCE are among the most commonly occurring compounds found in groundwater in a national ambient resources assessment conducted by the USGS (Zogorski and others, 2006). This may indicate that compounds found to frequently occur in broad-scale resource assessments also may be present in source water. This section focuses on compound occurrence in groundwater. Concentrations are evaluated in more detail in the "Comparison of Surface-Water and Groundwater Occurrence" section.

A wide variety of compounds were detected in groundwater samples. Compounds from 7 of the 13 use groups were found to commonly occur indicating that a wide variety of sources and pathways exist for these compounds to reach these wells. The use group with the largest number of commonly occurring compounds was the herbicides and herbicide degradates group followed by the solvents and disinfection by-products groups (fig. 6).

Nine of the 28 commonly occurring compounds in groundwater were herbicides and herbicide degradates. Their frequency of detection is due, in part, to their widespread use compared to other compounds and may be an artifact of the larger number of herbicides analyzed in samples in comparison to other compounds. Previous studies indicate that herbicide degradates typically occur with their parent compounds at concentrations similar to or greater than concentrations of their parent compounds (Thurman and others, 1992; Kalkhoff and others, 1998; Gilliom and others, 2006). Two degradates of atrazine, 2-hydroxyatrazine and deethylatrazine, are examples of compounds that are detected more frequently than the parent compound (Thurman and others, 1992; Kalkhoff and others, 1998; Gilliom and others, 2006). Atrazine and both degradates were among the most frequently detected herbicides and herbicide degradates, detected in about 3 to 4 percent of the samples at an assessment level of $0.05 \mu \mathrm{g} / \mathrm{L}$. The degradate 2-hydroxyatrazine was the most frequently detected herbicide degradate and the most frequently detected compound in the herbicides and herbicide degradates use group (detected in 3.9 percent of samples using an assessment level). The degradate 2-hydroxyatrazine was detected in 10.3 percent of samples without an assessment level with concentrations ranging from 0.001 to $0.24 \mu \mathrm{g} / \mathrm{L}$ and a median concentration of $0.03 \mu \mathrm{g} / \mathrm{L}$. Deethylatrazine was the second most frequently detected herbicide degradate using an assessment level (detected in 3.4 percent of samples). Deethylatrazine was detected in 32.5 percent of samples without an assessment level with concentrations ranging from 0.001 to $0.28 \mu \mathrm{g} / \mathrm{L}$ and a median concentration of $0.01 \mu \mathrm{g} / \mathrm{L}$, and atrazine was the most frequently detected herbicide (third most frequently detected compound in the herbicide and herbicide degradate use group) using an assessment level, detected in 2.7 percent of samples. Atrazine was detected in 27.8 percent of samples without an assessment level with concentrations ranging from 0.001 to $0.44 \mu \mathrm{g} / \mathrm{L}$ and a median concentration of $0.01 \mu \mathrm{g} / \mathrm{L}$. The frequency of atrazine occurrence is due, in part, to the widespread use as a weed control on crops and trees. 


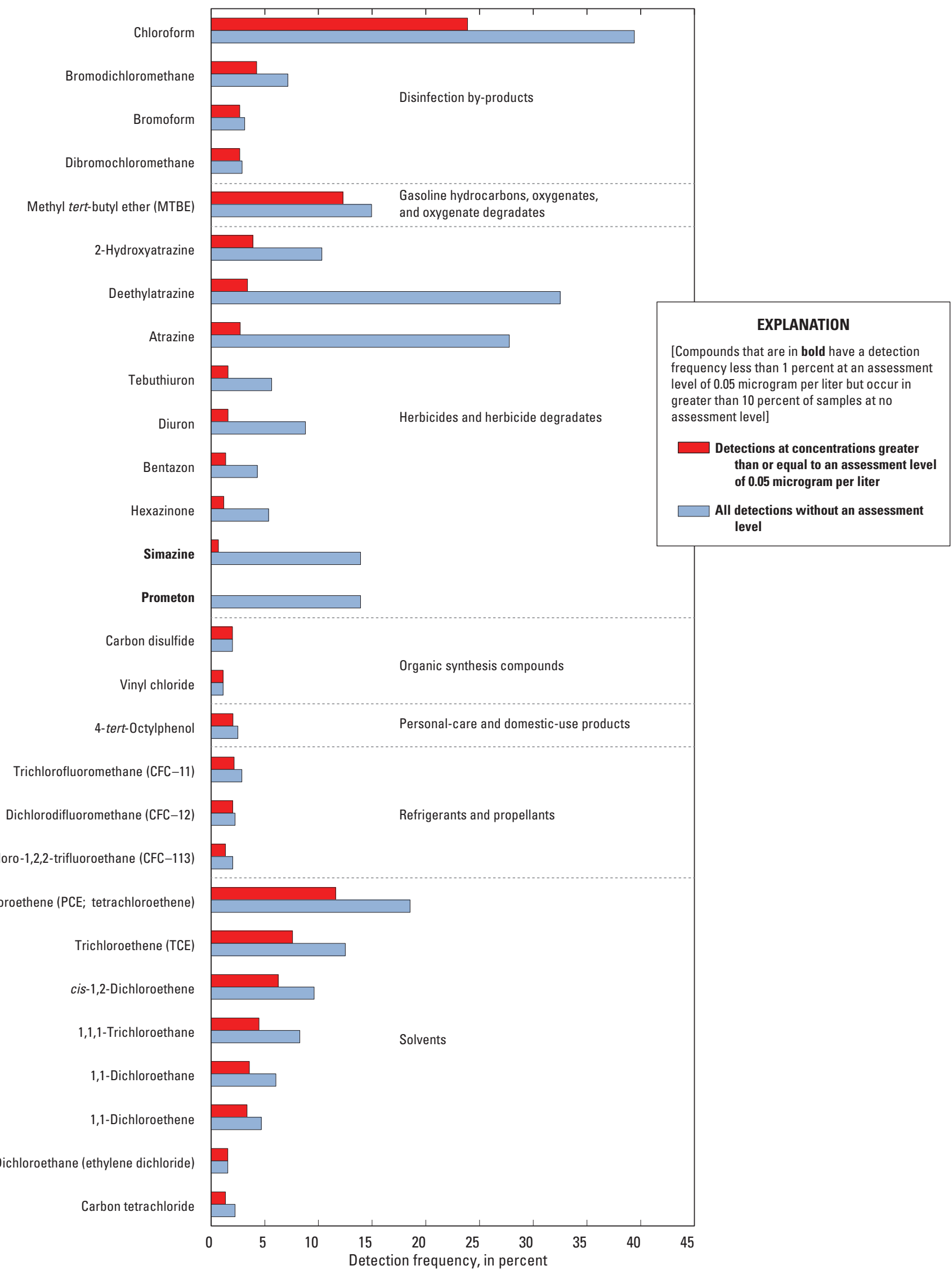

Figure 7. Commonly occurring compounds in source water derived from groundwater. 
The U.S. Environmental Protection Agency (2012d) reported that an estimated 75 percent of all field corn acreage grown in the United States is treated with atrazine.

Solvents were the second most commonly occurring use group in groundwater. Their frequent detection is due, in part, to their widespread use in both industry and in household consumer products, such as oven cleaners and household degreasers (U.S. Environmental Protection Agency, 1980; Zogorski and others, 2006). Solvents also are used to decaffeinate coffee and tea and for the extraction of hops (Halogenated Solvents Industry Alliance, 2010). Perchloroethene was the most frequently detected solvent, detected in 11.6 percent of the samples at an assessment level of $0.05 \mu \mathrm{g} / \mathrm{L}$. Perchloroethene was detected in 18.5 percent of samples without an assessment level with concentrations ranging from 0.01 to $76.8 \mu \mathrm{g} / \mathrm{L}$ and a median concentration of $0.09 \mu \mathrm{g} / \mathrm{L}$. The solvent, methyl ethyl ketone (MEK), though not one of the commonly occurring compounds, was detected at the highest concentration $(2,940 \mu \mathrm{g} / \mathrm{L})$ of all AOCs, in one groundwater sample (appendix 5). MEK has various industrial uses and primarily is used as a solvent in protective coatings (U.S. Environmental Protection Agency, 1994). Methyl ethyl ketone also is a major component in adhesives, specifically as a component of polyvinyl chloride (PVC) glues. The high concentration of MEK could be attributed to the PVC glues that were used in the plumbing at the wellhead of the supply well sampled. The PVC glues may have contaminated the water at the sampling point, and the high concentration may not represent the concentration of MEK in the aquifer.

Four disinfection by-products commonly occurred in groundwater samples. Using an assessment level of $0.05 \mu \mathrm{g} / \mathrm{L}$, chloroform was the most frequently detected disinfection byproduct (23.9 percent), followed by bromodichloromethane (detected in 4.2 percent), bromoform (detected in 2.7 percent), and dibromochloromethane (detected in 2.7 percent). Chloroform was detected in 39.4 percent of samples without an assessment level with concentrations ranging from 0.009 to $24.7 \mu \mathrm{g} / \mathrm{L}$ and a median concentration of $0.07 \mu \mathrm{g} / \mathrm{L}$. Bromodichloromethane was detected in 7.1 percent of samples without an assessment level with concentrations ranging from 0.016 to $0.79 \mu \mathrm{g} / \mathrm{L}$ and a median concentration of $0.06 \mu \mathrm{g} / \mathrm{L}$. Bromoform was detected in 3.1 percent of samples without an assessment level with concentrations ranging from 0.035 to $1.9 \mu \mathrm{g} / \mathrm{L}$ and a median concentration of $0.37 \mu \mathrm{g} / \mathrm{L}$. Dibromochloromethane was detected in 2.9 percent of samples with concentration ranging from 0.048 to $1.01 \mu \mathrm{g} / \mathrm{L}$ and a median concentration of $0.19 \mu \mathrm{g} / \mathrm{L}$. Chloroform and the other three disinfection by-products analyzed in samples (bromodichloromethane, bromoform, and dibromochloromethane) commonly are produced during the chlorination of water and wastewater (Ivahnenko and Zogorski 2006). Sources of these disinfection by-products to groundwater can include, in part, municipally supplied chlorinated water to irrigate lawns, golf courses, parks, gardens, and other areas; regulated discharge of chlorinated wastewater to rivers or groundwater recharge facilities; leakage of chlorinated water from swimming pools, spas, or distribution systems for drinking water or wastewater sewers; domestic well disinfection through chlorination (shock chlorination); laundry wastewater containing bleach; or septic system effluent (Ivahnenko and Zogorski 2006; Carter and others, 2012).

Three of the 28 commonly occurring compounds were on the CCL3: 1,1-dichloroethane, diuron, and MTBE. The compound 1,1-dichloroethane was detected in 6 percent of samples without an assessment level with concentrations ranging from 0.011 to $4.89 \mu \mathrm{g} / \mathrm{L}$ and a median concentration of $0.11 \mu \mathrm{g} / \mathrm{L}$. Diuron was detected in 8.8 percent of samples without an assessment level with concentrations ranging from 0.003 to $0.17 \mu \mathrm{g} / \mathrm{L}$ and a median concentration of $0.021 \mu \mathrm{g} / \mathrm{L}$. Methyl tert-butyl ether was detected in 15 percent of samples without an assessment level with concentrations ranging from 0.027 to $2.96 \mu \mathrm{g} / \mathrm{L}$ and a median concentration of $0.14 \mu \mathrm{g} / \mathrm{L}$. The frequent occurrence of these compounds in groundwater samples may warrant consideration for future monitoring and possible consideration by other Federal and State programs.

\section{Comparison of Surface Water and Groundwater Occurrence}

Many factors affect the occurrence of the AOCs monitored in both surface water and groundwater used as sources of drinking water. To better understand the spatial occurrence of compounds in source waters, a geographic distribution of the number of commonly detected compounds detected in samples without an assessment level is shown in figure 8 . In general, 11 or more compounds were detected in samples collected from rivers in the more populated areas located east of the Mississippi River. Similarly, three or more compounds were detected in samples collected from supply wells in these same areas of the country. Fewer compounds were detected in samples collected from rivers and supply wells west of the Mississippi River than east of the Mississippi River. None of the samples from one surface-water site (Cache la Poudre River) had any detections of AOCs. Samples collected from most of the supply wells in the Midwest (that is, Iowa, Illinois, and Wisconsin) and in Tennessee and Louisiana had no compounds detected. Spatially evaluating the number of compounds detected in surface water and groundwater illustrates how possible sources of these compounds and factors such as population can affect these two source water types.

Although most comparisons within this study primarily focus on the most commonly occurring compounds, a brief overview of all compounds monitored is warranted. Of the 265 AOCs monitored at all sites, 158 compounds were detected in one or more surface-water samples, representing 12 of the 13 use groups (appendix 2). The three compounds in the refrigerants and propellants group were not detected in surface-water samples. A total of 156 AOCs were detected in one or more groundwater samples, which included all 13 use groups (appendix 3). About one-half the 265 compounds monitored (122) were detected in one or more samples collected 


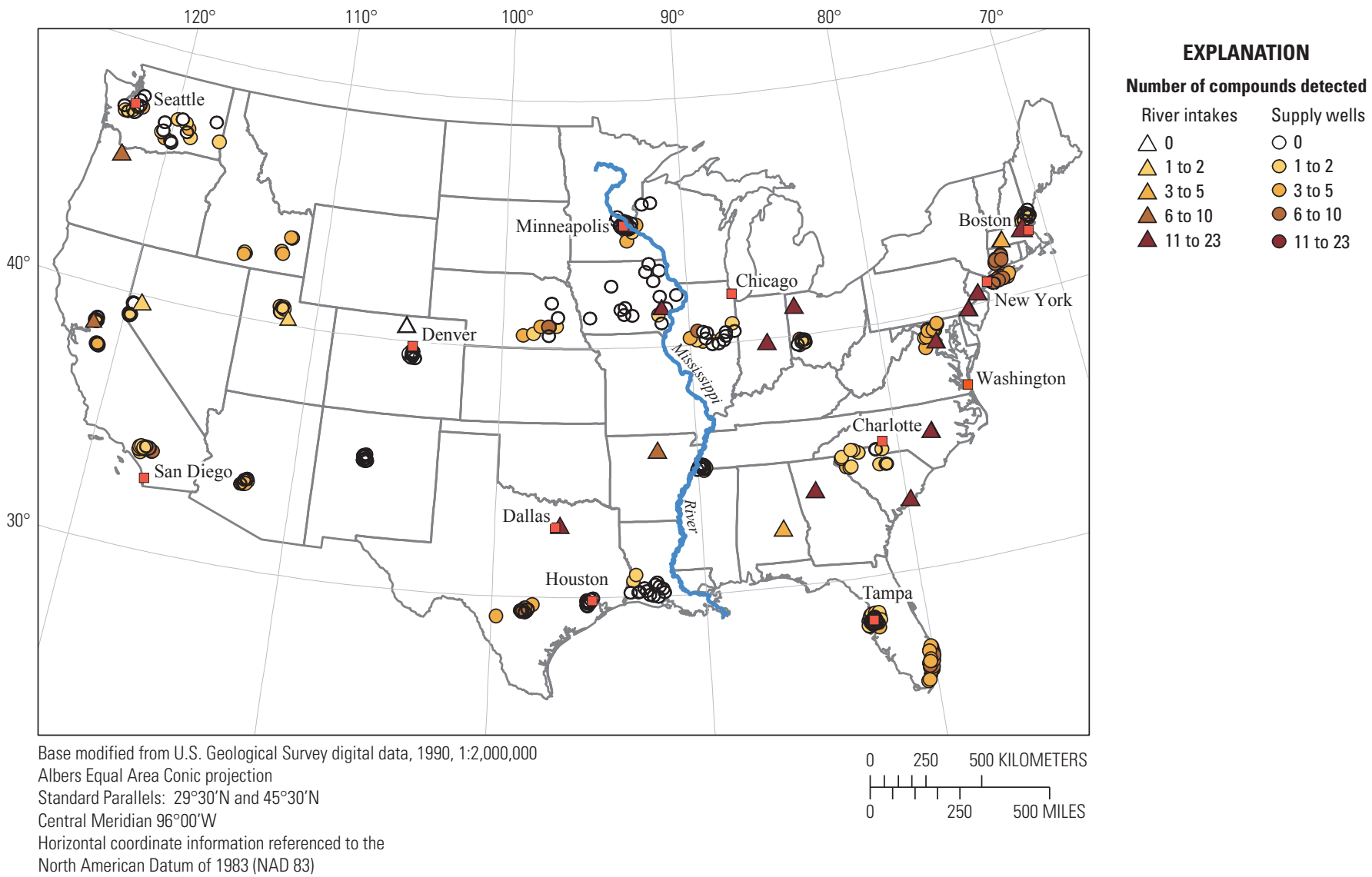

Figure 8. Geographic distribution of the number of commonly detected compounds without an assessment level in surface-water and groundwater samples collected from 20 river intakes and 448 supply wells during 2002-10.

from both surface water and groundwater. About 28 percent of the compounds monitored (73 of 265 AOCs) were never detected in either type of water samples. About 14 percent of the compounds monitored (36 AOCs) were detected only in surface-water samples, whereas about 13 percent (34) were detected only in groundwater samples. Of the 68 herbicide and herbicide degradates monitored at all sites, 54 percent (37) were detected in one or more samples of both water types. Most (19 of 27) of the gasoline hydrocarbons, oxygenates, and oxygenate degradates that were monitored were detected in one or more samples of both water types. All 4 disinfection by-products and all 5 plant- or animal-derived biochemicals were detected in both water types. The occurrence of compounds with varying uses in both water types further indicates that these compounds have a variety of sources and pathways to enter water supplies.

Comparisons of the occurrence of the most commonly occurring compounds in surface water and groundwater were made using no assessment level. A common assessment level is not used when comparing river and groundwater results because comparisons of the same compound and use group were made between water types. Therefore, the analytical sensitivity that would otherwise warrant an assessment level when comparing between compounds or use groups is no longer necessary.
The 71 and 28 commonly occurring compounds identified in surface water and groundwater, respectively (figs. 6 and 7), were used as the primary basis for comparison between surface water and groundwater. Combining these two lists resulted in 84 compounds used for comparisons between the two water types. It is important to note that the 84 compounds were defined as commonly occurring in one or both water types.

A more diverse suite of commonly occurring compounds was detected in surface water than groundwater (fig. 9). The occurrence of compounds from a variety of use groups indicates that a wide variety of sources and pathways exist for these compounds to reach both types of source water. Herbicides and herbicide degradates were the most commonly detected group of compounds in surface water and groundwater. Beyond that similarity, a different chemical signature was observed between the two water types. The gasoline hydrocarbons, oxygenate, and oxygenate degrades group and the personal-care and domestic-use products group were the next most frequently detected use groups in surface-water samples. Solvents were the second most frequently detected group in groundwater, followed by disinfection by-products, and refrigerants and propellants.

Of the 84 commonly occurring compounds, 65 compounds were detected in one or more samples of both surface 

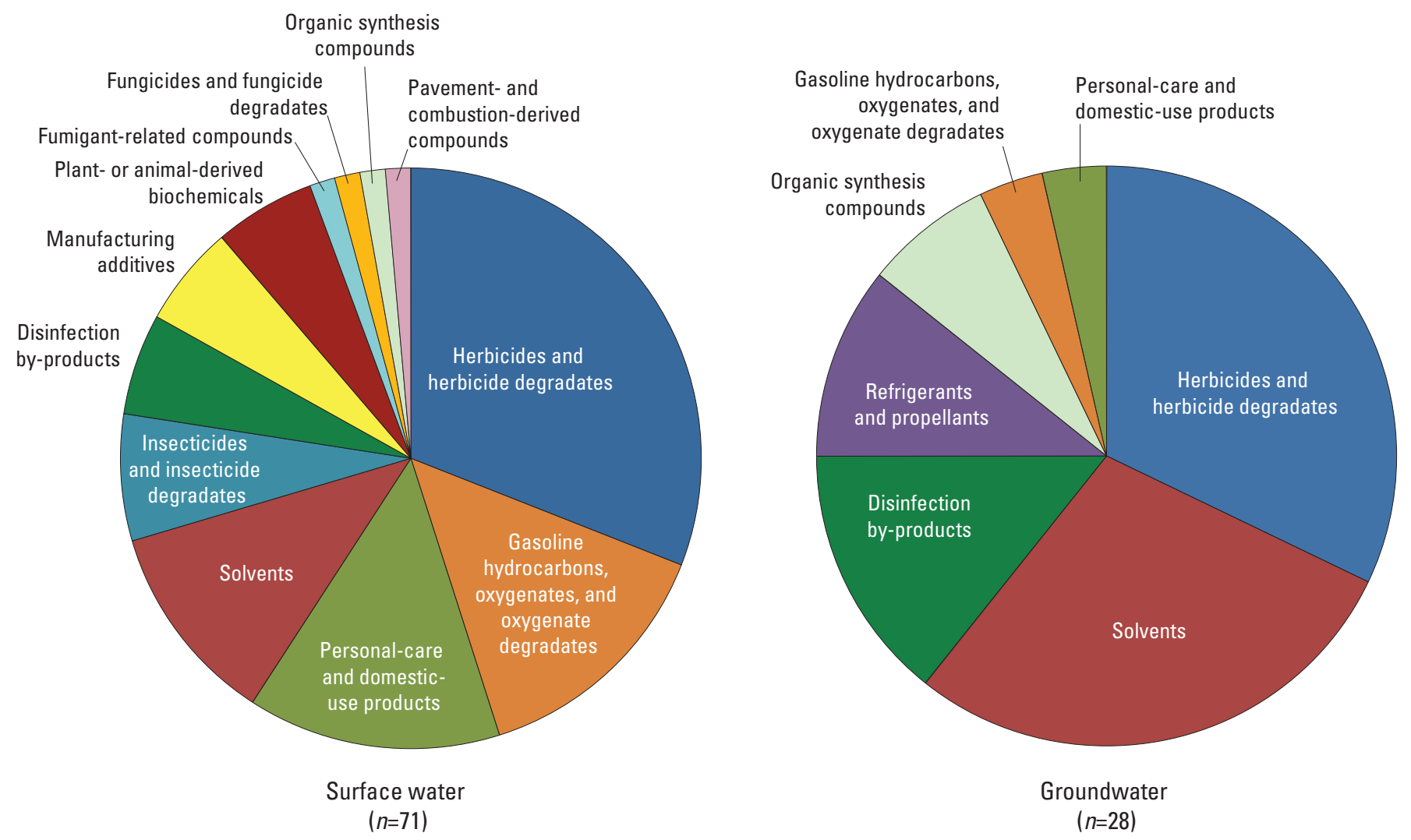

NOTE: $n$ equals the number of commonly occurring compounds (detected in greater than or equal to 1 percent of samples at an assessment level of 0.05 microgram per liter or in greater than 10 percent of samples without an assessment level)

Figure 9. Characterization of use groups for commonly occurring compounds in surface water and groundwater.

water and groundwater. For commonly occurring compounds detected in both water types, the detection frequency was higher for surface-water samples than groundwater samples; however, concentrations were not significantly different (ranksum test; $p$-value $=0.4292$ ) (fig. 10). When detected, concentrations of the 84 compounds ranged from 0.0003 to $20.1 \mu \mathrm{g} / \mathrm{L}$ in surface-water samples and from 0.0005 to $2,090 \mu \mathrm{g} / \mathrm{L}$ in groundwater samples. The median concentrations were $0.029 \mu \mathrm{g} / \mathrm{L}$ and $0.032 \mu \mathrm{g} / \mathrm{L}$ for surface water and groundwater, respectively. Concentrations for a small subset of detections were greater than $1 \mu \mathrm{g} / \mathrm{L}$ ( 2 and 5 percent in surface water and groundwater, respectively). Most of the concentrations (63 and 61 percent in surface water and groundwater, respectively) were less than $0.05 \mu \mathrm{g} / \mathrm{L}$. This highlights the significance of low-level analytical and field processing methods to gain a better understanding of the occurrence of these types of compounds in source water.

Analysis of individual use groups for the 65 commonly occurring compounds in both surface water and groundwater indicated different patterns in concentrations between surface water and groundwater. Compounds in the herbicides and herbicide degradates group and the personal-care and domesticuse products group were detected more frequently in surface water than groundwater, and concentrations of compounds in both use groups were significantly greater in surface water than in groundwater (fig. 11). Some disinfection by-products and solvents were detected more frequently in surface water, whereas others were detected more frequently in groundwater; however, concentrations were significantly larger ( $p$-values less than 0.05) for both groups of compounds in groundwater (fig. 12). These findings indicate that although compounds generally may be more frequently detected in surface water than groundwater and have similar concentrations, both detection frequency and concentration may be larger in either water type depending on the compound's primary use and physical/ chemical properties. For example, solvents may occur more frequently at larger concentrations in groundwater than surface water because of their volatility. Similarly, personal-care and domestic-use products may occur more frequently at higher concentrations in surface water because of their introduction to rivers from wastewater effluent discharges or other sources. This highlights the importance of understanding the sources and pathways for a compound to enter source water as well as the compound's physical and chemical properties.

Four compounds in surface water and three compounds in groundwater were commonly occurring and are included 

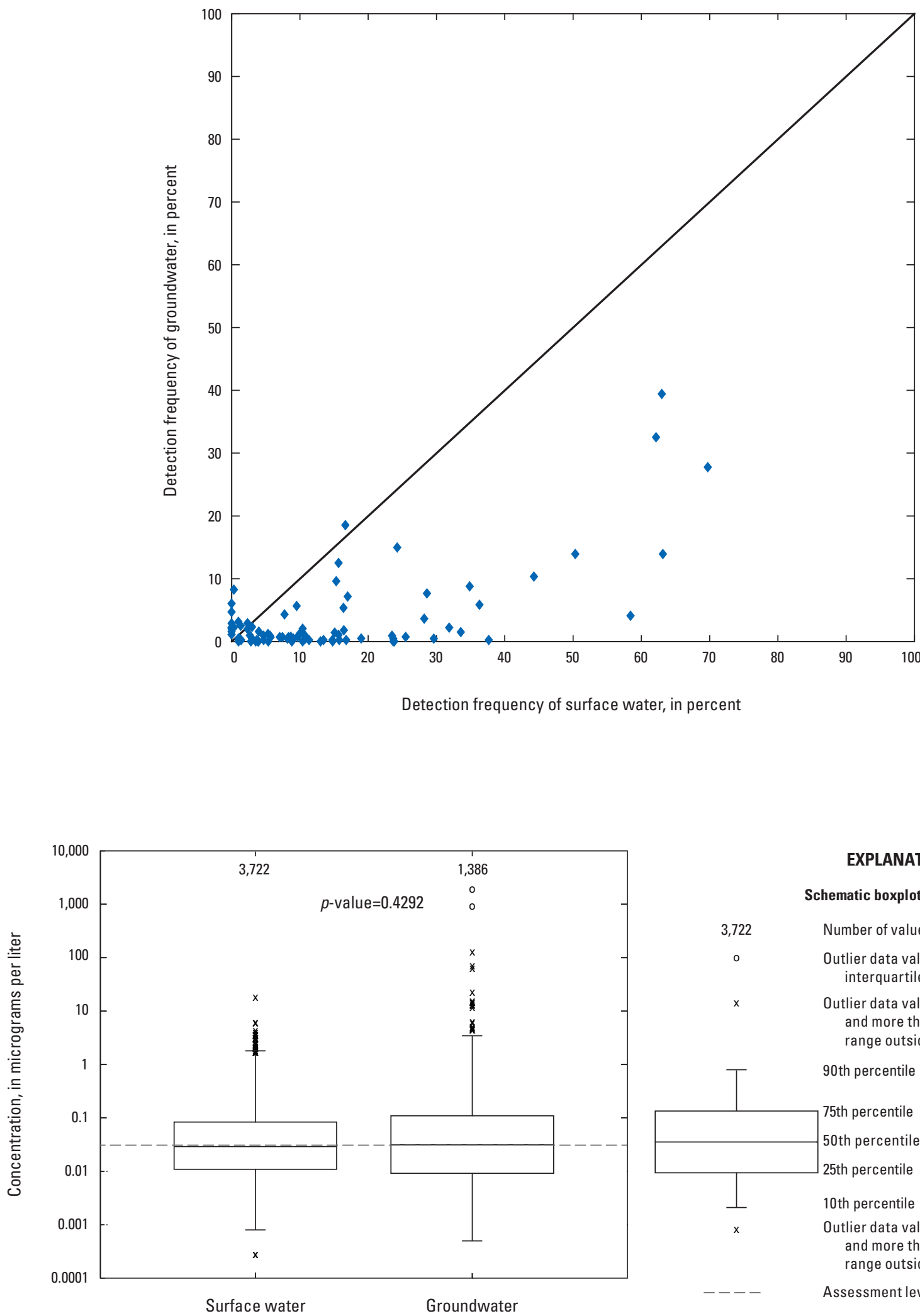

EXPLANATION

Schematic boxplot

Number of values

Outlier data value more than 3 times the interquartile range outside the quartile

Outlier data value greater than or equal to 3 and more than 1.5 times the interquartile range outside the quartile

90th percentile

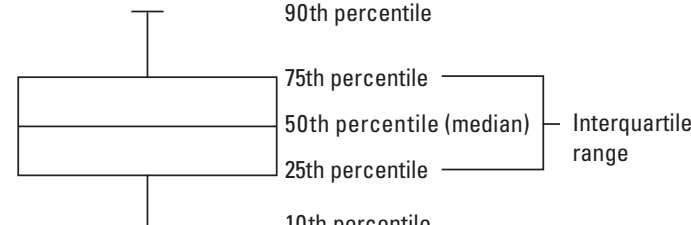

$x \quad$ Outlier data value less than or equal to 3 and more than 1.5 times the interquartile range outside the quartile

Assessment level of 0.05 microgram per liter

Figure 10. Detection frequency and quantified concentrations of 65 commonly occurring compounds in both surface water and groundwater using no assessment level. 

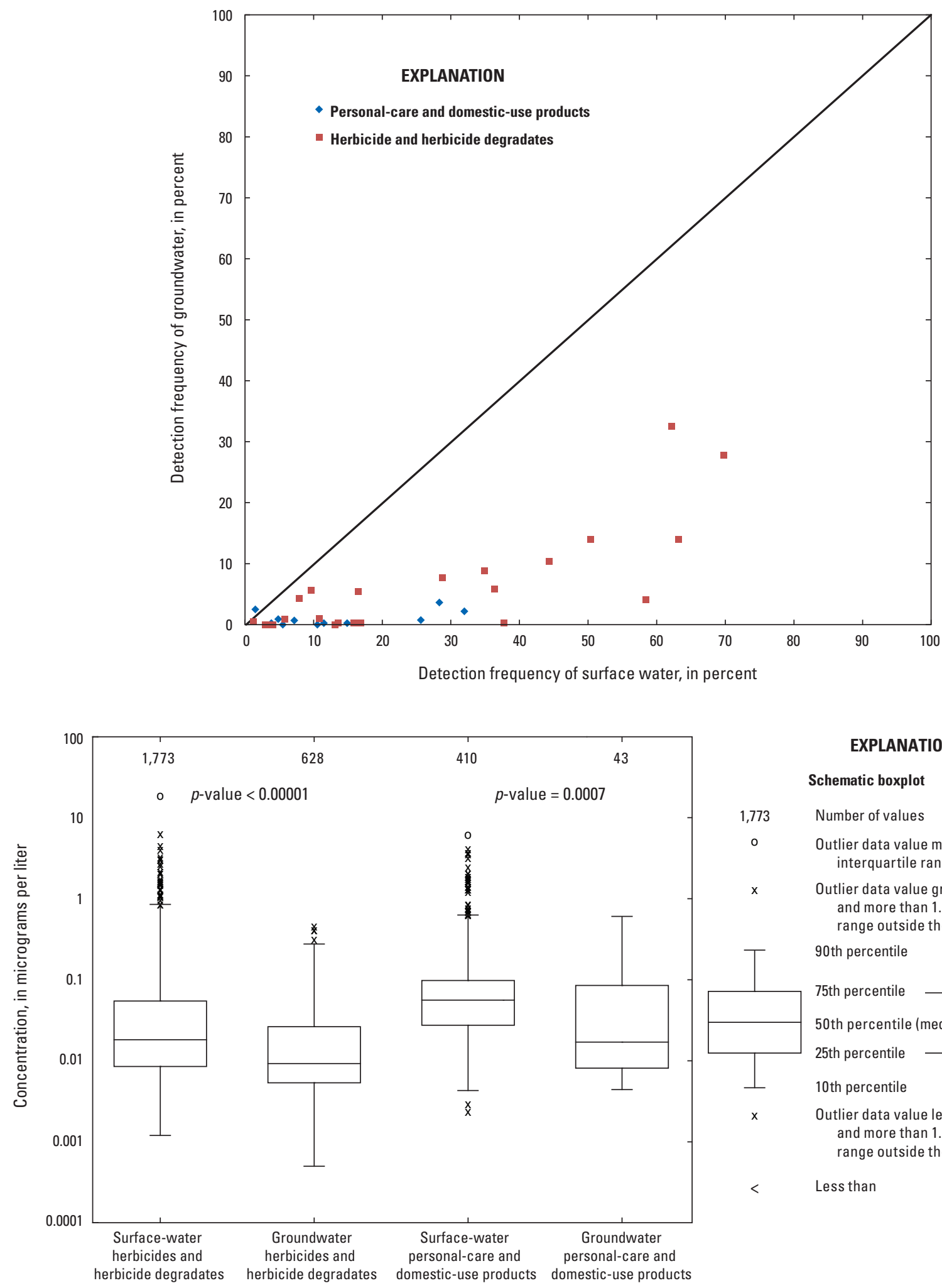

EXPLANATION

Schematic boxplot

1,773 Number of values

- Outlier data value more than 3 times the interquartile range outside the quartile

Outlier data value greater than or equal to 3 and more than 1.5 times the interquartile range outside the quartile

90 th percentile

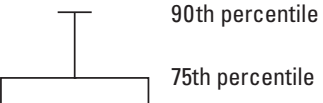

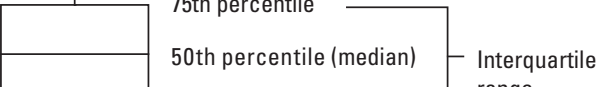
25th percentile r range

10th percentile

Outlier data value less than or equal to 3 and more than 1.5 times the interquartile range outside the quartile

$<\quad$ Less than

Figure 11. Detection frequency and quantified concentrations of commonly occurring herbicide and herbicide degradates and personal-care and domestic-use products in surface water and groundwater. 

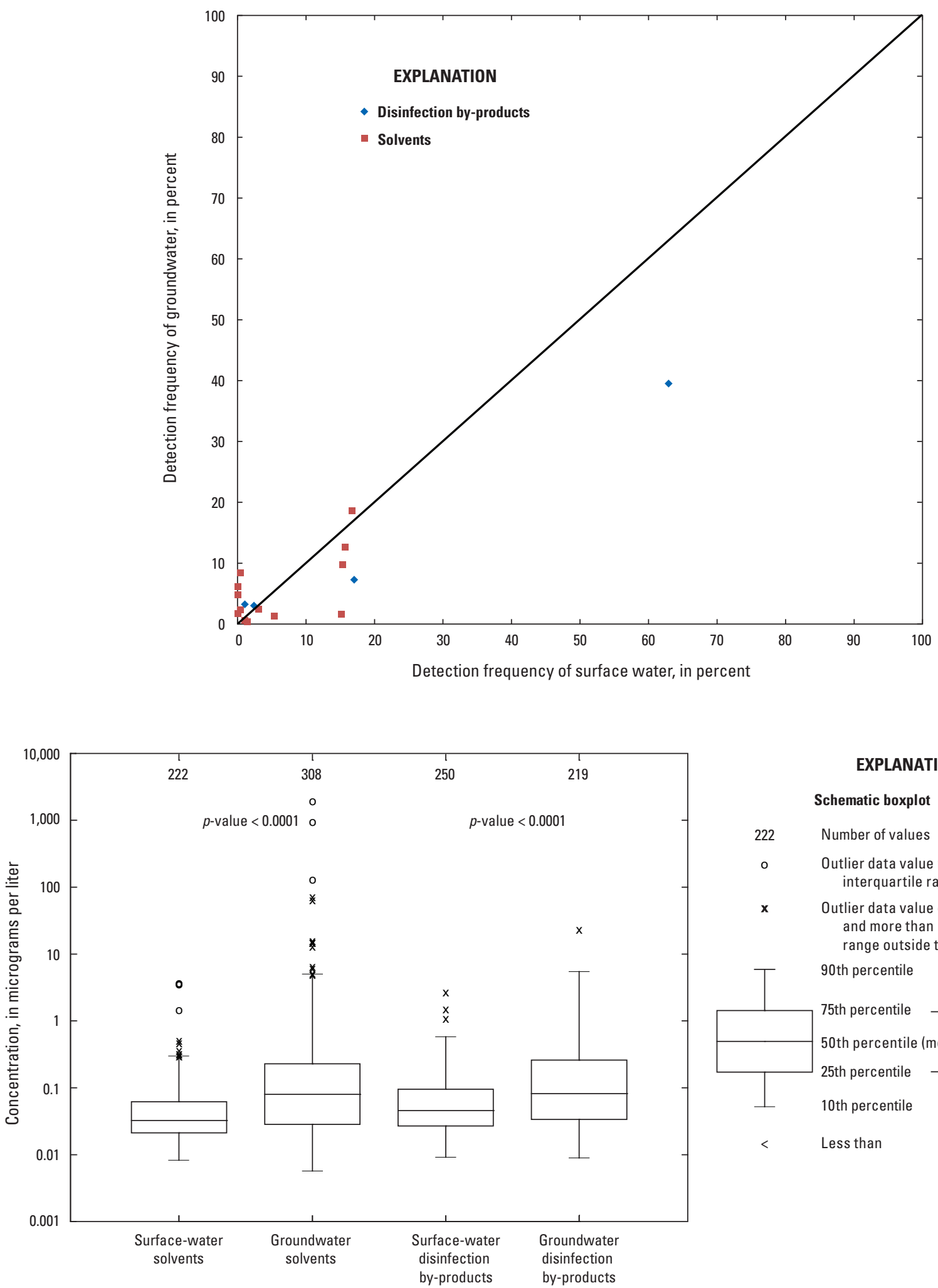

EXPLANATION

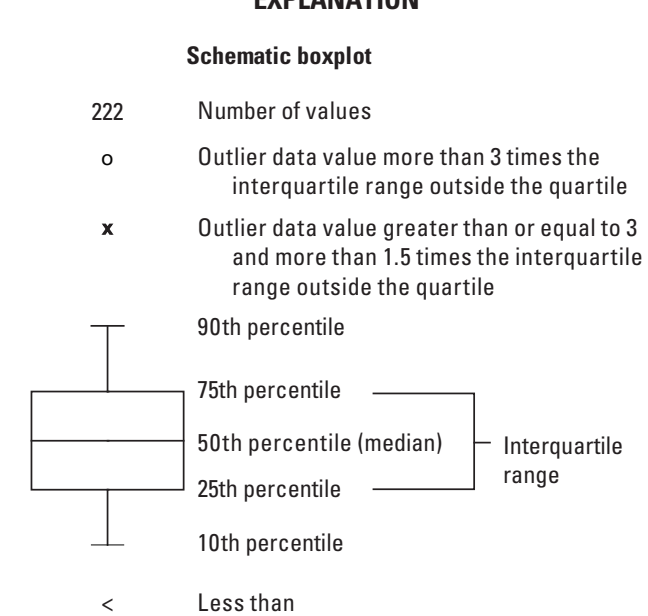

Figure 12. Detection frequency and quantified concentrations of commonly occurring disinfection by-products and solvents in surface water and groundwater. 
on the CCL3 list. Two of these compounds on the CCL3 were found to occur commonly, at no assessment level, in samples of both water types: MTBE and diuron. The gasoline oxygenate MTBE was detected more frequently in surface water $(24.3$ percent) than in groundwater (15 percent). Similarly, the herbicide diuron was detected more frequently in surface water (34.9 percent) than in groundwater (8.8 percent). The frequent occurrence at no assessment level of these two compounds in surface-water and groundwater samples may warrant consideration for future monitoring and possible consideration by other Federal and State programs.

\section{Comparison of Results to Human-Health Benchmarks in Surface Water and Groundwater}

Human-health benchmarks were available for more than one-half the compounds (160 of the 265) that were monitored at all sites. Of the most commonly occurring compounds in surface water, 58 percent ( 41 of 71 AOCs) have a humanhealth benchmark to which concentrations can be compared. Of the 71 compounds that are commonly occurring in surface-water samples, 19 have MCLs and 22 have HBSLs. Five compounds had concentrations greater than or within one-tenth of a benchmark: 4 herbicides and herbicide degradates and 1 insecticide (fig. 13A). Two of the five compounds (simazine and atrazine) have MCLs, and acetochlor, diuron, and fipronil have HBSLs. Atrazine was the only compound to have concentrations greater than the benchmark. Atrazine concentrations were greater than the MCL in three samples, all of which were collected from the same site (White River in Indiana). Although only 3 samples had concentrations greater than the MCL, atrazine had many (35) detections within onetenth of the benchmark. Fipronil and simazine had 18 and 14 detections, respectively, within one-tenth of the benchmark. None of the five compounds had an annual mean concentration within one-tenth of the benchmark; the median concentration of the annual mean concentrations for each site is shown on figure 13.

Of the 28 most commonly occurring compounds in groundwater, 24 compounds have a human-health benchmark to which concentrations can be compared: 14 compounds have MCLs and 10 compounds have HBSLs. Nine of the most commonly occurring compounds had concentrations greater than or within one-tenth of a benchmark: 1 disinfection by-product (chloroform), 1 herbicide (atrazine), 1 organic synthesis compound (vinyl chloride), and 6 solvents (fig. 13B). All nine compounds - chloroform, atrazine, vinyl chloride, 1,1-dichloroethene, 1,2-dichloroethane, carbon tetrachloride, cis-1,2-dichloroethene, perchloroethene (PCE), and trichloroethene (TCE) - have MCLs to which concentrations can be compared. Perchloroethene and TCE were the only compounds with concentrations greater than the benchmark. Concentrations of PCE were greater than the MCL in 3 samples and within one-tenth of the benchmark in 9 samples. Concentrations of TCE were greater than the MCL in 3 samples and within one-tenth of the benchmark in 5 samples. Concentrations of 1,1-dichloroethene in four samples and concentrations of vinyl chloride in three samples were within one-tenth of their respective benchmarks. Concentrations of atrazine in 2 samples and concentrations of chloroform, 1,2-dichloroethane, carbon tetrachloride, and cis-1,2-dichloroethene in 1 sample were within one-tenth of their respective benchmarks.

Three compounds detected in surface-water samples that were not commonly occurring - iprodione, molinate, and dieldrin - had concentrations within one-tenth of a human-health benchmark (appendix 4). Dieldrin was the only compound with a median concentration of the annual mean concentrations that was greater than its human-health benchmark when compared to the low end $\left(10^{-6}\right)$ of the HBSL range $\left(10^{-6}\right.$ to $10^{-4}$ cancer risk level; Toccalino and others, 2008). However, dieldrin was only detected in 2 of 306 samples, and one-quarter of the LRL (which was used in calculating the median of the annual mean concentration for nondetected concentrations) was larger than the low end of the HBSL. As such, the median of the annual mean concentration for dieldrin may be overestimated. Because of this, future monitoring for dieldrin may need to consider the use of a lower-level analytical method.

In groundwater, some compounds that were not commonly occurring had concentrations greater than a humanhealth benchmark value including 1,2-dibromo-3-chloropropane; 1,2-dibromoethane; dieldrin (low end of HBSL range); and acrylonitrile (low end of HBSL range) (appendix 5). Other compounds that did not exceed a benchmark value but that had concentrations within one-tenth of a benchmark include benzene, alachlor, and methyl ethyl ketone (MEK) (appendix 5).

Rivers had almost one-half as many commonly occurring compounds (5) within at least one-tenth of a benchmark in comparison to groundwater (9) (fig. 13). However, the number of times these compounds exceed one-tenth of a benchmark was about twice as often as in groundwater. In general, concentrations in groundwater are thought to be relatively stable for longer periods of time in comparison to temporal concentration fluctuations in rivers (Schroeder 2003; Bender and others, 2009). As such, the common occurrence (more than 10 percent) in either water type is considered to be equally important.

Of the 265 compounds monitored, 105 compounds do not have a human-health benchmark (an MCL for regulated compounds or an HBSL for unregulated compounds) to compare concentrations with. Of these 105 compounds, 49 were detected in one or more samples of both types of source water. With respect to the 84 commonly occurring compounds in surface water, groundwater, or both, about two-thirds (52 of the 84) have a human-health benchmark, whereas 32 do not have a human-health benchmark. Of these 32,17 were detected in 10 percent or more source-water samples from either water type (table 6). For these 17 compounds, their frequent occurrence in surface water or groundwater, or both, directly supplying CWSs may warrant the development of appropriate toxicity information that would allow the ability to calculate an HBSL value (or range in values) to which 


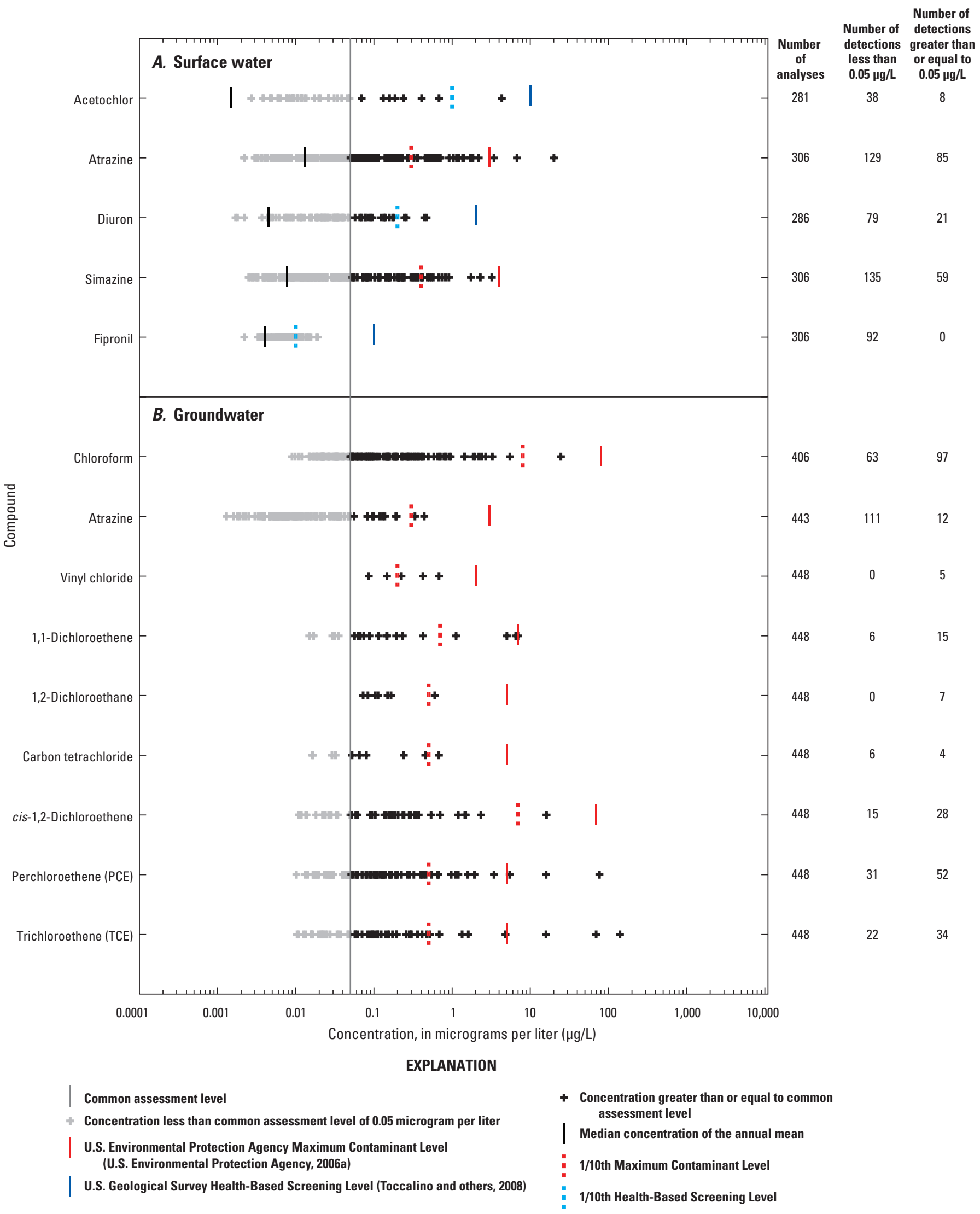

Figure 13. Commonly occurring compounds with concentrations that exceeded or were within one-tenth of a benchmark in $A$, surface water and $B$, groundwater. 
Table 6. List of compounds without a human-health benchmark that were detected in greater than 10 percent of samples from surface water or groundwater, or both (no assessment level).

[Shaded rows indicate compounds on U.S. Food and Drug Administration Generally Recognized As Safe list (U.S. Department of Health and Human Services, 2011). CASRN, Chemical Abstract Services Registry Number; --, no information available]

\begin{tabular}{|c|c|c|c|}
\hline Compound name & CASRN ${ }^{a}$ & \multicolumn{2}{|c|}{ Detection frequency (percent) } \\
\hline Deethylatrazine & $6190-65-4$ & 62 & 33 \\
\hline 3,4-Dichloroaniline & $95-76-1$ & 36 & 6 \\
\hline Hexahydrohexamethyl-cyclopentabenzopyran (HHCB) & $1222-05-5$ & 32 & 2 \\
\hline Acetyl hexamethyl tetrahydronaphthalene (AHTN) & $21145-77-7$ & 26 & 1 \\
\hline Tri(2-butoxyethyl)phosphate & $78-51-3$ & 24 & 0 \\
\hline Desulfinylfipronil & -- & 24 & 0.4 \\
\hline Tris(dichlorisopropyl) phosphate & $13674-87-8$ & 23 & 1 \\
\hline Camphor & $76-22-2$ & 11 & 0.2 \\
\hline Nonylphenol, diethoxy- (total) & $26027-38-2$ & 10 & 0 \\
\hline 1,2,4-Trimethylbenzene & $95-63-6$ & 10 & 1 \\
\hline Caffeine & $58-08-2$ & 28 & 4 \\
\hline Triethyl citrate & $77-93-0$ & 15 & 0.2 \\
\hline
\end{tabular}

${ }^{a}$ This report contains Chemical Abstracts Service Registry Numbers (CASRN) ${ }^{\circledR}$, which is a Registered Trademark of the American Chemical Society. The CASRN online database provides the latest registry number information: http://www.cas.org/. Chemical Abstracts Service recommends the verification of the CASRNs through CAS Client Services ${ }^{\mathrm{SM}}$.

${ }^{\mathrm{b}}$ Although no human-health benchmark (MCL or HBSL) has been developed for MTBE, the U.S. Environmental Protection Agency has issued a drinking water advisory of 20-40 micrograms per liter for MTBE to avert unpleasant tase and odor effects (U.S. Environmental Protection Agency, 1997).

concentration data can be compared. Lacking this information, it is not possible to interpret results for these compounds in a human-health context.

Two compounds without a human-health benchmarkdeethylatrazine and MTBE-were found to occur in more than 10 percent of samples in both water types and may warrant priority development of HSBLs. Deethylatrazine was the most commonly detected compound without a humanhealth benchmark in surface water (62 percent) and groundwater (33 percent). Methyl tert-butyl ether was detected in 24 and 15 percent of surface-water and groundwater samples, respectively. Although no human-health benchmark (MCL or HBSL) has been developed for MTBE, the U.S. Environmental Protection Agency has issued a drinking-water advisory of 20-40 micrograms per liter for MTBE to avert unpleasant taste and odor effects (U.S. Environmental Protection Agency, 1997). The remaining 15 compounds without human-health benchmarks only occurred in more than 10 percent of surfacewater samples (table 5). Two of these compounds - triethyl citrate and caffeine - may not warrant the development of a human-health benchmark because they are included on the U.S. Food and Drug Administration's Generally Recognized As Safe (GRAS) list (U.S. Department of Health and Human Services, 2011).

\section{Factors Affecting the Occurrence of Compounds in Surface Water and Groundwater}

Most of the AOCs monitored in this study are used in urban or agricultural settings, or both. Some compounds enter source waters after application on the land surface, such as herbicides and insecticides that are used in both types of settings, but are used more systematically in agricultural settings. Transport to surface water occurs with rainfall and runoff and also from groundwater discharge that has been affected by infiltration of herbicides and insecticides or other AOCs with recharge. Sources of other groups of compounds, such as solvents and organic synthesis compounds, primarily are from accidental releases or historical disposal in landfills (Zogorski and others, 2006). A source of personal-care and domestic use 
compounds is the discharge of treated wastewater to streams (Kingsbury and others, 2008).

In surface water, the amount of urban and agricultural land in the watershed was related to the occurrence of commonly occurring compounds in source water (fig. 14A). The number of commonly occurring compounds detected in surface-water samples generally increased as the amount of urban and agricultural land increased (fig. 14A). Most surfacewater sites had a median of 5 or more compounds detected in samples with a maximum of 26 compounds. Samples from sites for which approximately 25 percent or more of the watershed had urban and agricultural land use (about one-half of the sites) typically had 14 or more compounds detected. Conversely, only 1 or 2 compounds were detected in samples from sites with 5 percent or less urban and agricultural land use.

The herbicides and herbicide degradates group were the most commonly detected use group in surface water. With the exception of the Cashe la Poudre site, at least one herbicide was detected at each site, and the number of samples with detections and the summed concentrations of herbicides generally increased with the amount of agricultural land use in the watershed (fig. 15). For example, sites with larger percentages (that is, greater than 10 percent) of agricultural land were more likely to have samples with total herbicide concentrations greater than $1 \mu \mathrm{g} / \mathrm{L}$. The summed concentrations of herbicides for samples from sites with less than 10 percent agricultural land use almost always were less than $0.1 \mu \mathrm{g} / \mathrm{L}$.

Atrazine and simazine were two of the most commonly occurring herbicides, but their occurrence relative to the amount of agricultural land in the watershed differed. Both atrazine and simazine have agricultural and nonagricultural uses, but simazine has substantial nonagricultural use (Gilliom and others, 2006; Kingsbury and others, 2008). The association between simazine occurrence, in particular the concentrations at which it was detected, and the amount of agricultural land in the watershed, is much less evident than that of atrazine (fig. 15).

In general, some of the more commonly detected compounds in rivers have chemical signatures indicating municipal or industrial wastewater discharge. Examples of some of the more frequently occurring compounds in rivers include hexahydrohexamethylcyclopentabenzopyran (HHCB), chloroform, tris(dichlorisopropyl) phosphate, cholesterol, and 3-beta-coprostanol. Results from this study are consistent with other national studies that have linked these compounds to wastewater discharges (Kolpin and others, 2002; Kingsbury and others, 2008). For example, the fragrance compound HHCB was the most frequently occurring compound in rivers at an assessment level of $0.05 \mu \mathrm{g} / \mathrm{L}$. Hexahydrohexamethylcyclopentabenzopyran commonly is used in detergents and other personal-care products and has been found in both influent and effluent of wastewater-treatment plants in the United States and Europe (Bester, 2004; Phillips and others, 2005). The disinfection by-product, chloroform, was the second most commonly detected compound in rivers and may be present in treated wastewater because of the household use of bleach

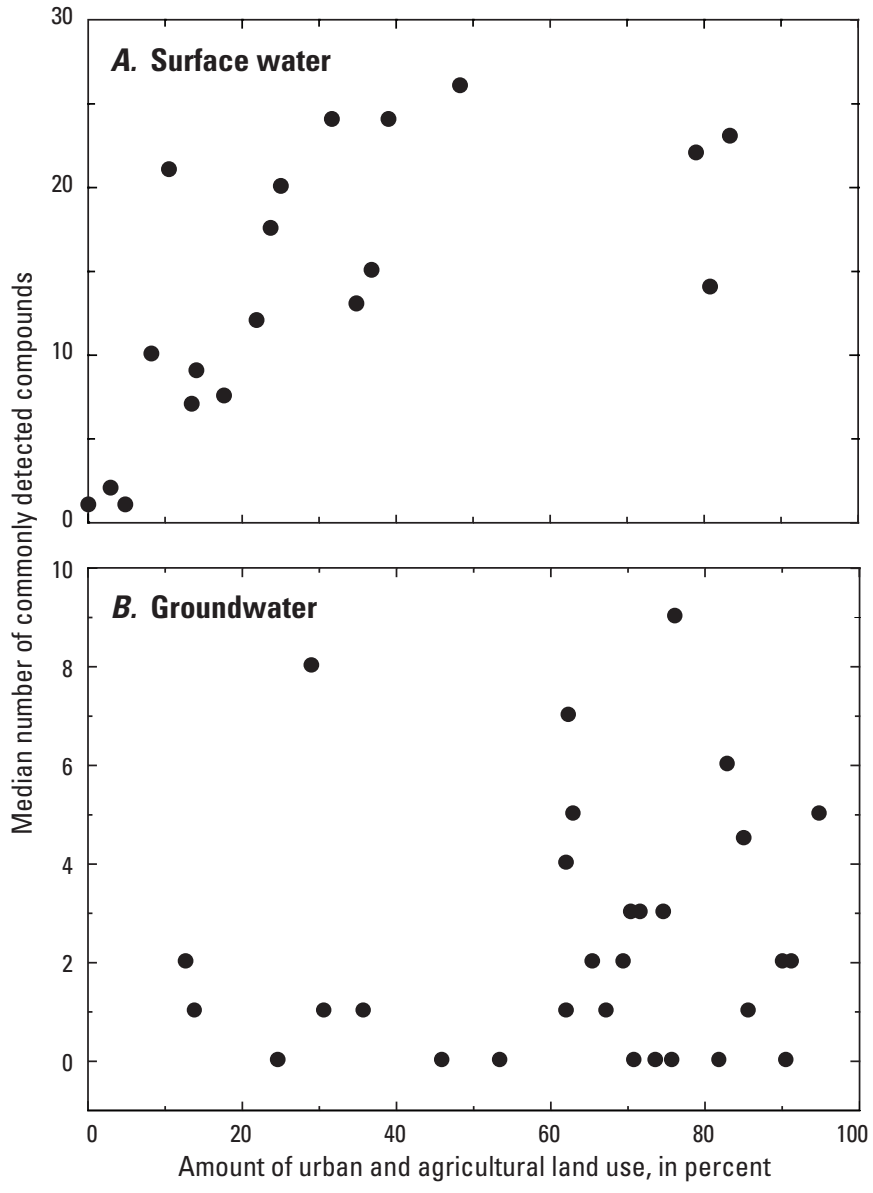

Figure 14. Relation between median number of commonly occurring compounds detected and the amount of urban and agricultural land use in the watershed or contributing area without an assessment level at $A$, surface-water sites and $B$, groundwater studies.

as well as the disinfection of wastewater during the treatment process (Ivahnenko and Barbash, 2004; Zogorski and others, 2006). Other possible sources of chloroform include artificial recharge of wastewater, its use as a refrigerant for home air conditioners and large commercial freezers, and its use in reagents, extraction solvents, fumigants, insecticides, and as a precursor for dyes and pesticides (Budavari, 1989; Mannsville Chemical Products Corporation, 1999; Lucius and others, 1992; Agency for Toxic Substance and Disease Registry, 1997; Zogorski and others, 2006). The manufacturing additive tris(dichlorisopropyl)phosphate and the biochemicals cholesterol and 3-beta-coprostanol were detected in 13, 19, and 9 percent of samples, respectively, with an assessment level of $0.05 \mu \mathrm{g} / \mathrm{L}$. These three compounds were detected in a national reconnaissance of emerging compounds in rivers that receive a substantial amount of municipal, industrial, or agricultural wastewater discharge (Kolpin and others, 2002; Kingsbury and others, 2008). The occurrence of these compounds in rivers that receive major wastewater discharge is consistent with several studies that indicate organic compounds, such as 


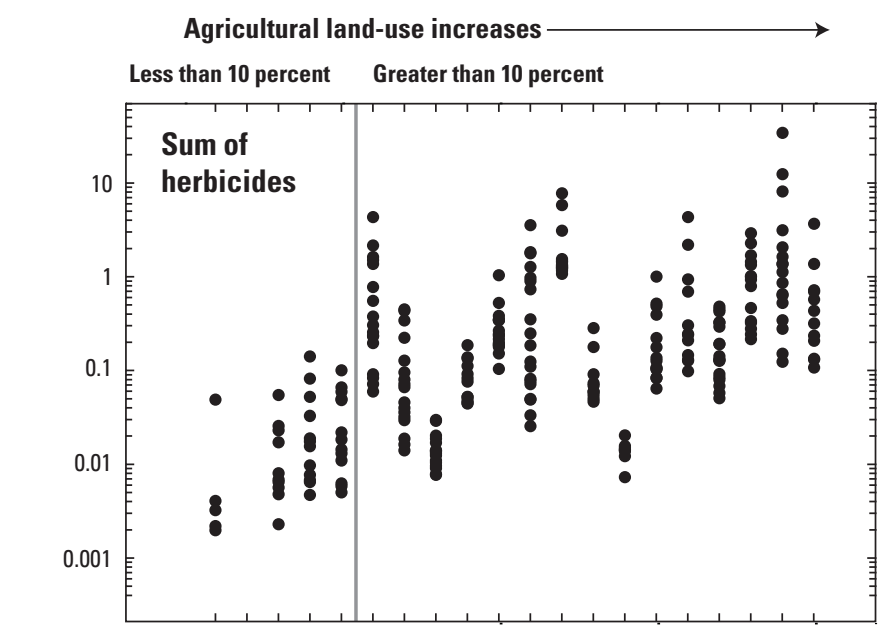

\section{EXPLANATION}

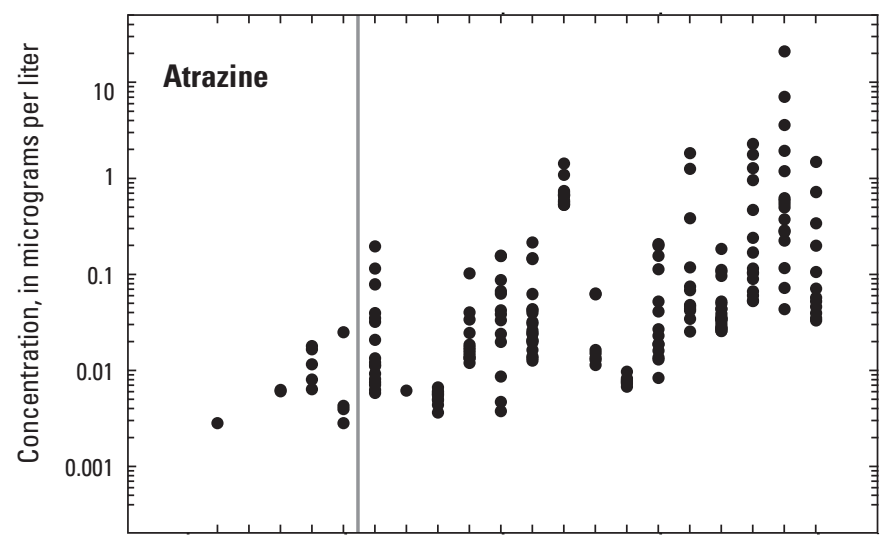

$\begin{array}{ll}\text { Study unit identifier (table 1) } \\ \text { ACFB } & \text { Apalachicola-Chattahoochee-Flint River Basins } \\ \text { ALBE } & \text { Albemarle-Pamlico Drainage Basins } \\ \text { CONN } & \text { Connecticut, Housatonic, and Thames River Basins } \\ \text { DELR } & \text { Delaware River Basin } \\ \text { EIWA } & \text { Eastern lowa Basins } \\ \text { GRSL } & \text { Great Salt Lake Basins } \\ \text { LERI } & \text { Lake Erie-Lake Saint Clair Drainages } \\ \text { LINJ } & \text { Long Island-New Jersey Coastal Drainages } \\ \text { MOBL } & \text { Mobile River Basin } \\ \text { NECB } & \text { New England Coastal Basins } \\ \text { NVBR } & \text { Nevada Basin and Range } \\ \text { OZRK } & \text { Ozark Plateaus } \\ \text { PODL } & \text { Potomac River Basin and Delmarva Peninsula } \\ \text { SACR } & \text { Sacramento River Basin } \\ \text { SANT } & \text { Santee River Basin and Coastal Drainages } \\ \text { SPLT } & \text { South Platte River Basin } \\ \text { TRIN } & \text { Trinity River Basin } \\ \text { UMIS } & \text { Upper Mississippi River Basin } \\ \text { WHMI } & \text { White and Great and Little Miami River Basins } \\ \text { WILL } & \text { Willamette Basin }\end{array}$

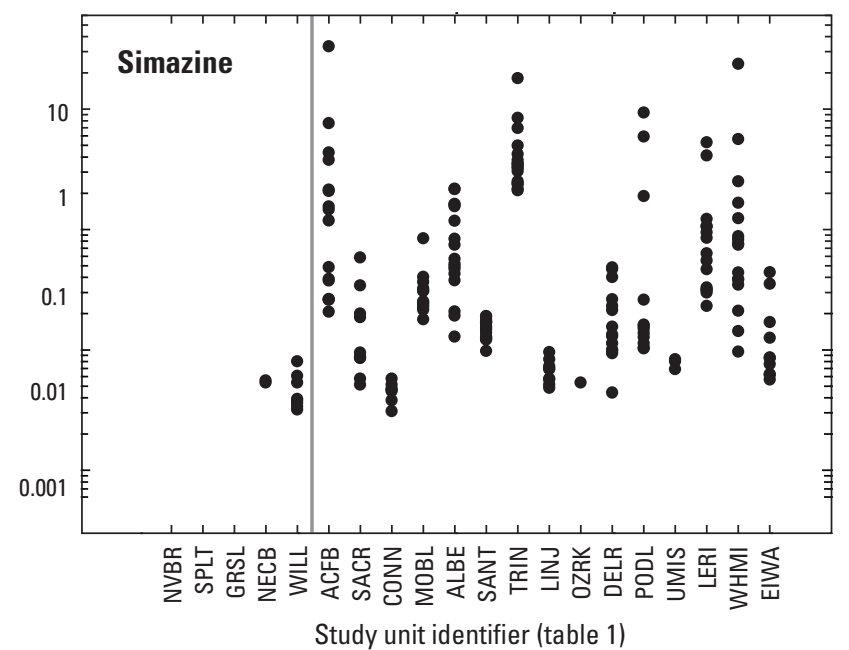

WILL Willamette Basin

Figure 15. Concentrations of herbicides detected without an assessment level in surface-water samples collected from rivers. 
manufacturing additives or animal biochemical compounds, are not removed during the wastewater-treatment process and are detected in the receiving rivers (Halling-Sørensen and others, 1998; Kolpin and others, 2002; Stackelberg and others, 2004; Kingsbury and others, 2008).

In groundwater, the more important factors affecting the occurrence of AOCs include the use of a compound in the contributing area, recharge, and aquifer rock type. Hopple and others (2009) used a subset of the data presented in this report to provide additional information on factors that affect the occurrence of compounds in groundwater. A generalized characterization of the occurrence of commonly detected compounds with respect to factors such as principal aquifer type and the use of compounds in a contributing area will help to put the results into context and explain some of the differences in the occurrence of compounds.

Compounds were found to occur most frequently in samples from wells in carbonate rock types, which were predominantly located in the northeastern part of the country, whereas sandstone aquifers had the lowest detection frequency among the principal aquifer rock types (fig. 16). In general, Hopple and others (2009) found that detection frequencies did not change substantially within a particular lithological group. However, additional factors such as the presence of confining units, well capacity, land use, population density, and the presence of sources of these compounds likely are important factors affecting the occurrence of these compounds.

Determining the land use in the watershed area of a river is relatively straightforward, but is much less so for determining the land use in the contributing area for supply wells. The contributing areas for wells can be approximated with a groundwater-flow model, but models typically are not readily available for most wells. In this study, land use in a 500-m buffer area around the wells was characterized and assumed to be representative of the land use for the actual contributing areas for the supply wells. This assumption likely is less valid as well depth and pumping capacity increase, but this approach provides an estimate and a framework within which results can be compared among groundwater sites.

Similar to the results for river sites, the number of commonly occurring compounds detected in samples from the supply wells generally increased as the amount of urban and agricultural land near the wells increased (fig. 14B). Most sites with less than 50 percent of these land uses in the contributing areas of the supply wells had detections of two or fewer compounds. For wells where urban and agricultural land use was greater than 50 percent in the contributing area, the median number of compounds detected often was two or more.

In surface water and groundwater, most of the organic compounds monitored in this study are used in urban or agricultural settings, or both. Some compounds end up in source waters after application on the land surface, such as herbicides and insecticides that are used in both types of settings, but are used more systematically in agricultural settings. To put results from this study into context with the national distribution of rivers and supply wells used by CWS, the river and supply-well sites sampled for this study were grouped into the respective national population of land-use quartiles (table 7). The increase in detection frequency with increasing urban and agricultural land use was more evident for samples from rivers than from supply wells (fig. 17). For rivers, the median detection frequency increased for each quartile, with more

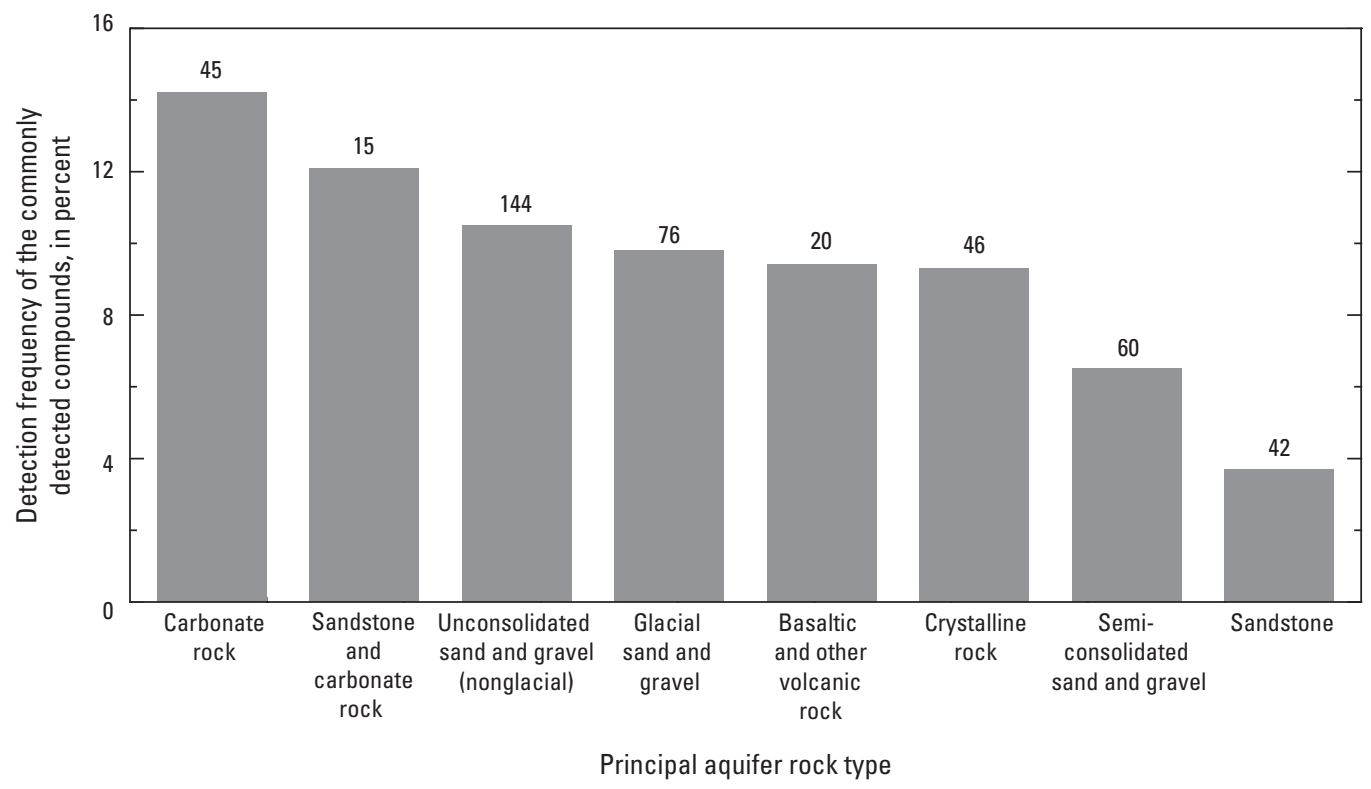

EXPLANATION

45 Number of wells

Figure 16. Detection frequencies without an assessment level of commonly detected compounds by principal aquifer rock type for samples from 448 supply wells collected during 2002-09. 
Table 7. Number of study sites sampled within land-use quartiles for 2,016 river intakes and 112,099 supply wells considered to represent the national distribution of river intakes and supply wells, respectively, supplying community water systems.

$[\leq$, less than or equal to; >, greater than; $n$, number of study locations sampled within this quartile]

\begin{tabular}{|c|c|c|c|c|}
\hline \multirow{2}{*}{ Category } & \multicolumn{4}{|c|}{ Quartile } \\
\hline & $\begin{array}{c}1 \\
\leq 25 \text { percent }\end{array}$ & $\begin{array}{c}2 \\
>25-50 \text { percent }\end{array}$ & $\begin{array}{c}3 \\
>50-75 \text { percent }\end{array}$ & $\begin{array}{c}4 \\
>75 \text { percent }\end{array}$ \\
\hline \multicolumn{5}{|c|}{ Rivers $(n=20)$} \\
\hline Agricultural land use (percent) & $0-0.03(n=1)$ & $0.04-9(n=4)$ & $9.1-27.2(n=9)$ & $27.3-94.7(n=6)$ \\
\hline Urban and agricultural land use (percent) & $0-3.1(n=1)$ & $3.2-17(n=5)$ & $17.1-38.2(n=6)$ & $38.3-100(n=8)$ \\
\hline Population density (people per square kilometer) & $0-2.5(n=1)$ & $2.6-13.8(n=1)$ & $13.9-37.2(n=8)$ & $37.3-3.49 \times 10^{9}(n=10)$ \\
\hline \multicolumn{5}{|c|}{ Supply wells ( $n=448)$} \\
\hline Agricultural land use (percent) & $0-0(n=272)$ & $0-5.5(n=51)$ & $5.6-31.2(n=83)$ & $31.3-100(n=42)$ \\
\hline Urban and agricultural land use (percent) & $0-18.6(n=60)$ & $18.7-45.6(n=79)$ & $45.7-73.8(n=132)$ & $73.9-100(n=177)$ \\
\hline Population density (people per square kilometer) & $0-31.6(n=50)$ & $31.7-146.5(n=48)$ & $146.6-461.9(n=97)$ & $462-31,431(n=253)$ \\
\hline
\end{tabular}

than 13 and 21 percent occurrence of any of the 84 commonly occurring compounds in samples from watersheds in the third and fourth quartiles of urban and agricultural land use (fig. 17A), respectively. These quartiles represent the national population of rivers with 17.1 percent or more urban and agricultural land use (quartiles 3 and 4; table 7) within their watersheds. Rivers with 3.2 to 17 percent urban and agricultural land use (quartile 2; table 7) had a median detection frequency of about 6 percent.

For groundwater, the median detection frequency for the commonly occurring compounds was lowest for the quartile with the least amount of urban and agricultural land and increased slightly from the second to third quartiles (fig. 17B). The difference in occurrence between the second, third, and fourth quartiles was small with median detection frequencies of about 3 percent in each of those quartiles. Urban and agricultural land use within the 500-m buffers around wells in these quartiles ranged from 18.7 to 100 (table 7).

Previous national assessments have shown that herbicide and herbicide degradates occur more frequently in rivers within an agricultural land-use setting (Gilliom and others, 2006). Similarly, solvents have been shown to occur more frequently in groundwater within an urban land-use setting than in any other land-use type (Zogorski and others, 2006). These studies focused primarily on ambient streams and shallow groundwater and were not specifically characterizing the quality of source water. However, findings herein compare favorably to previous assessments. This may indicate findings from ambient resource assessments are applicable to source waters used by community water systems (CWSs).

The increase in detection frequency of herbicides and herbicide degradates with increasing agricultural land use was more evident for rivers than for supply wells (fig. 18). For rivers, the median detection frequency increased for each quartile, with more than 30 and 36 percent occurrence of any of the 24 commonly occurring herbicides in samples from watersheds in the third and fourth quartiles of agricultural land use, respectively; collectively representing rivers with 9.1 percent or more agricultural land use within their watersheds (table 7; fig. 18A). The increase in each quartile indicates a strong correlation between the occurrence of herbicides and the amount of agricultural land use within the watershed. Similar to detection frequency, the median concentrations of herbicides and herbicide degradates in rivers increased as the amount of agricultural land use increased (fig. 18A). However, concentrations were low with median concentrations in the fourth quartile (most agricultural land) of about $0.03 \mu \mathrm{g} / \mathrm{L}$.

The occurrence of herbicides and herbicide degradates generally did not change with increasing agricultural land use within the contributing area for the supply well (fig. 18B). The median detection frequency was much less than 1 percent in the first three quartiles compared to about 5 percent in the fourth quartile. This slight increase in the fourth quartile indicates that wells located in areas with the largest amount of agricultural land use may be more susceptible to herbicides. When detected, the concentrations of herbicides and herbicide degradates in all four quartiles were low with a median 


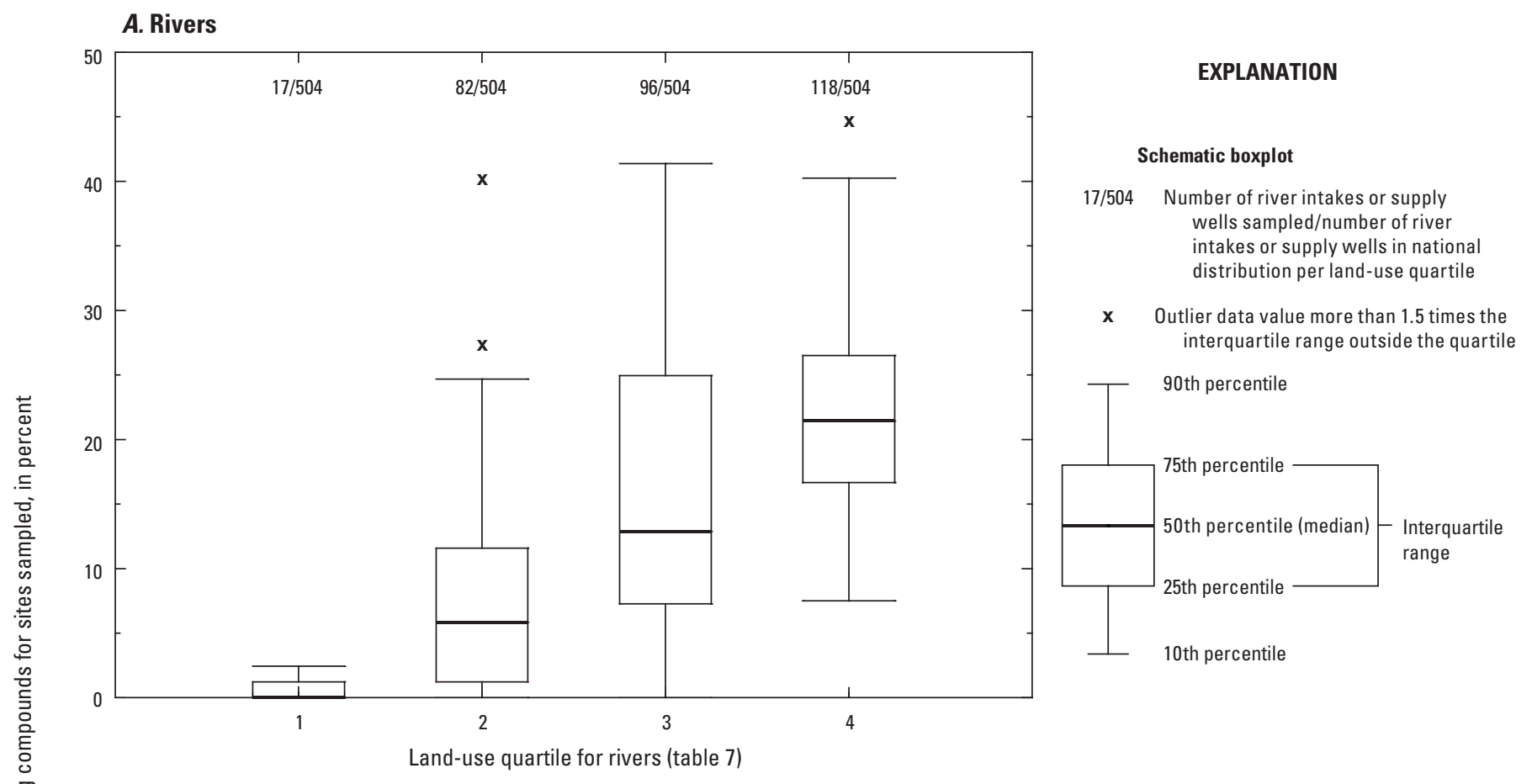

B. Groundwater

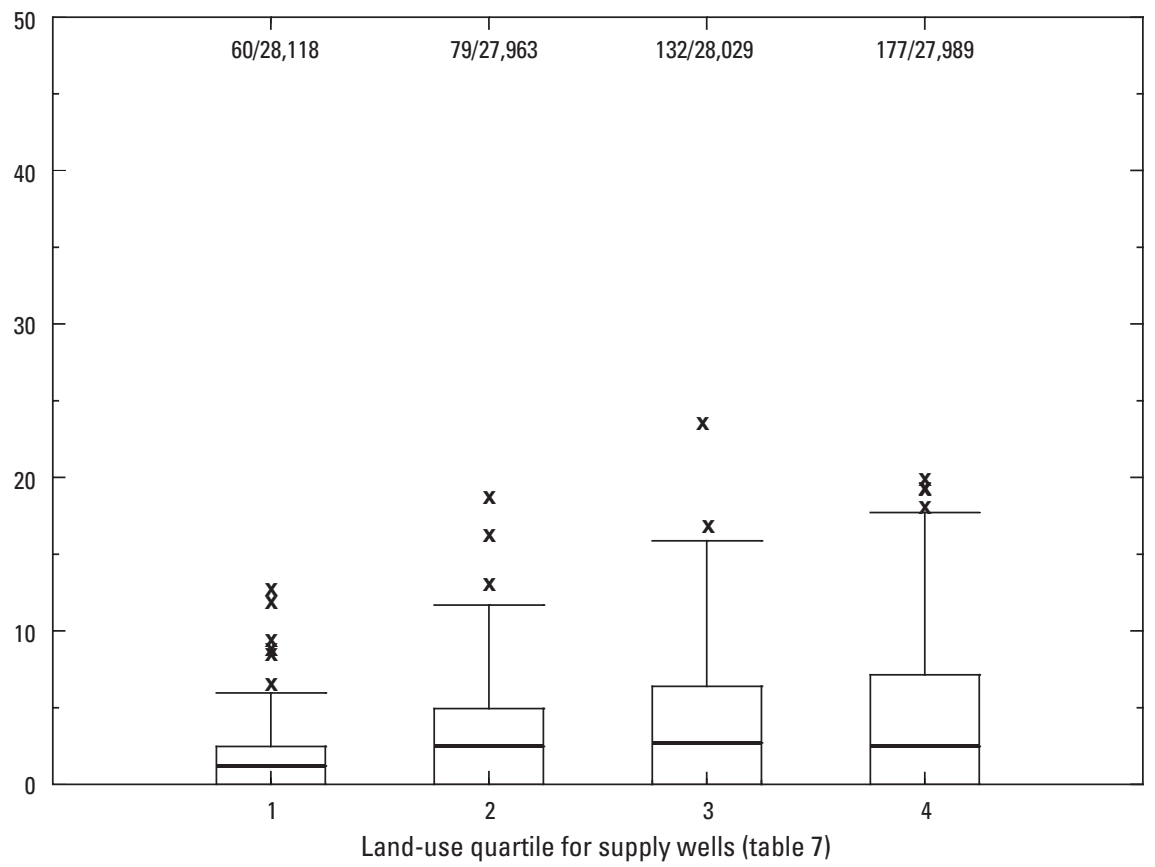

Figure 17. Detection frequency without an assessment level of commonly detected compounds within urban and agricultural land-use quartiles for 2,016 river intakes and 112,099 supply wells considered to represent the national distribution of river intakes and supply wells, respectively, supplying community water systems for $A$, rivers and $B$, supply wells. 

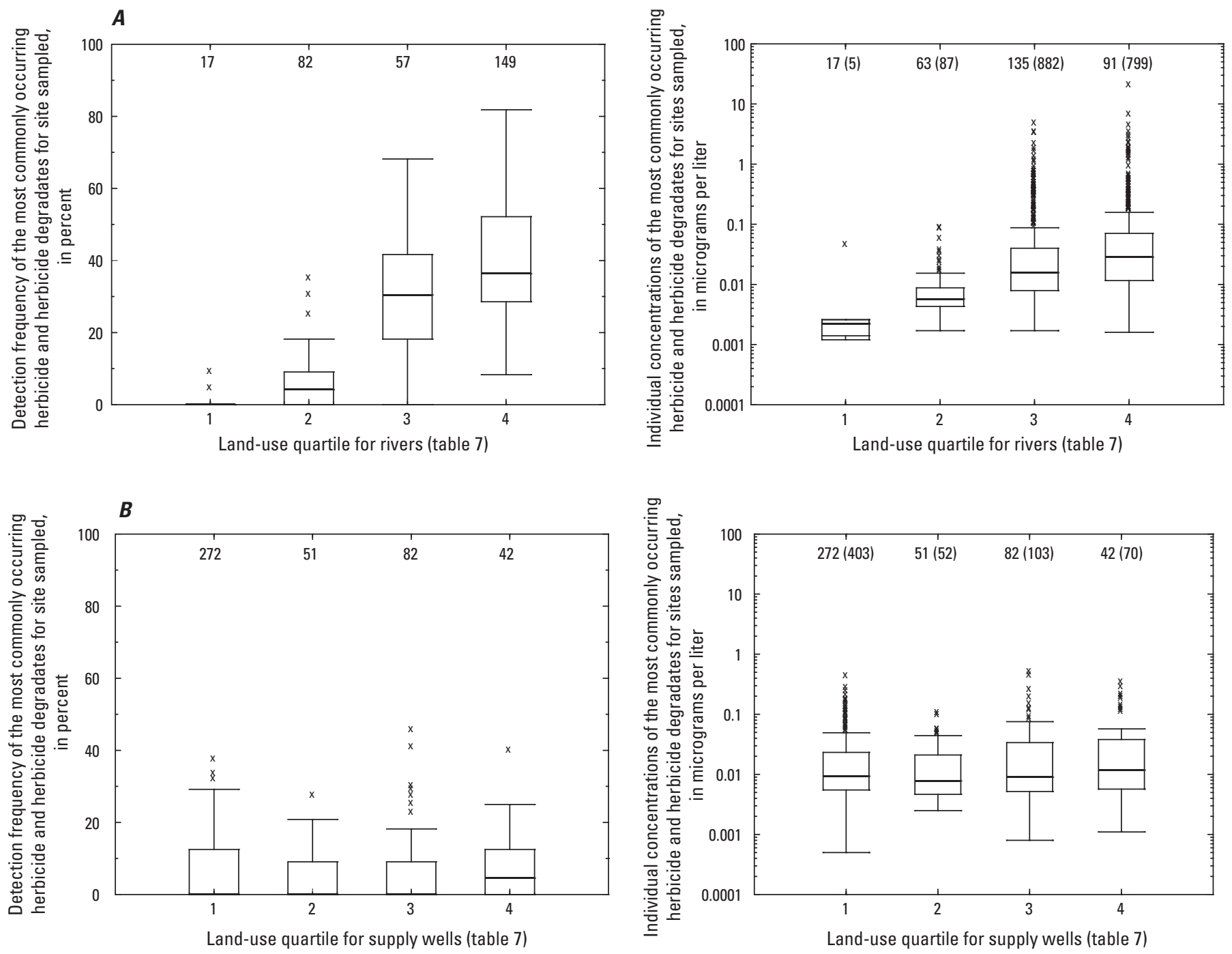

\section{EXPLANATION}

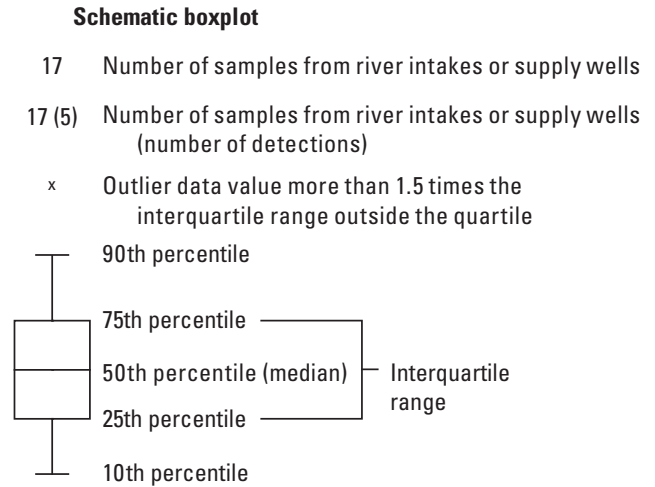

Figure 18. Occurrence and concentrations without an assessment level for commonly occurring herbicide and herbicide degradates within agricultural land-use quartiles for 2,016 river intakes and 112,099 supply wells considered to represent the national distribution of river intakes and supply wells, respectively, supplying community water systems for $A$, rivers and $B$, supply wells. 
concentration of about $0.01 \mu \mathrm{g} / \mathrm{L}$ (fig. 18B). These results indicate that concentrations of herbicides and herbicide degradates vary minimally in groundwater regardless of the percentage of agricultural land use in the contributing area. Compound detections can decrease with well depth (Hopple and others, 2009), but this relation was not evaluated for this report.

The occurrence of solvents did not change substantially with increasing urban land use for rivers or supply wells (fig. 19). For rivers, the median detection frequency increased only in the fourth quartile, with more than 8 percent occurrence of any of the 13 commonly occurring solvents in surface-water samples in the fourth quartile of urban land use (fig. 19A). When detected, the concentrations in all four quartiles were low with a median concentration of about $0.02 \mu \mathrm{g} / \mathrm{L}$ (fig. 19A). These results indicate that concentrations of solvents remain the same in surface water regardless of the percentage of urban land use in the watershed.

Although the range of occurrence and concentrations of solvents increased from one quartile to the next for rivers and supply wells, changes were slightly more evident for supply wells (fig. 19B).The increasing range in each quartile indicates that wells located in areas with the largest amount of urban land use may be susceptible to solvents. The median solvent concentration in the fourth quartile for supply wells $(0.08 \mu \mathrm{g} / \mathrm{L})$ was slightly higher than for river intakes (fig. 19B). These results indicate that as the percentage of urban land use increases in the contributing area, the concentration ranges for solvents increase.

Commonly occurring herbicides and herbicide degradates and commonly occurring solvents were separately put into context with the national distribution of river intakes and supply wells used by CWSs. Each of the sites was grouped into the respective national population of urban and agricultural land-use quartiles, and trends in occurrence and concentrations were assessed. In general, the increase in detection frequency of the most commonly occurring compounds associated with increasing amounts of agricultural and urban land use for both rivers and supply wells highlights the importance of source water and wellhead protection strategies.

\section{Mixtures in Surface Water and Groundwater}

In addition to assessing the occurrence of individual compounds in source-water samples from surface water and groundwater, the occurrence and characteristics of mixtures in these samples also were evaluated. Human exposure to compounds is rarely limited to a single compound, and so more emphasis recently has been placed on health risks from exposure to mixtures (Hasegawa and others, 1994; Yang, 1994; Toccalino and others, 2010; Toccalino and others, 2012).

As a first step toward evaluating the potential importance of mixtures of AOCs to source-water quality, a basic cooccurrence analysis was completed using no assessment level. Although nearly all single-sample concentrations of individual compounds detected were low (median detected concentration less than $0.03 \mu \mathrm{g} / \mathrm{L}$ ), most samples contained mixtures of two or more compounds (fig. 20). In surface water, approximately 86 percent of source-water samples contained two or more compounds, and 50 percent of samples contained at least 14 compounds. Twenty-five percent of samples contained at least 22 compounds. In groundwater, 50 percent of samples contained at least three compounds. Twenty-five percent of samples contained at least six compounds.

The co-occurrence analyses also were completed for surface water and groundwater using an assessment level of $0.05 \mu \mathrm{g} / \mathrm{L}$ (fig. 20). At least 4 compounds in surface water and at least 1 compound in groundwater were detected in 50 percent of samples with an assessment level. The additional compounds found to co-occur as mixtures when not using an assessment level for both surface water and groundwater highlights the significance of low-level compound co-occurrence.

With respect to unique mixtures, the most commonly occurring compounds were examined in two categories: with and without an assessment level. Characterizing mixtures in these categories will begin to explain the most important compounds monitored that typically co-occur as a mixture in surface water and groundwater.

Using an assessment level of $0.05 \mu \mathrm{g} / \mathrm{L}$ for the 25 most commonly occurring compounds, the 10 most frequently co-occurring mixtures in surface water include combinations of herbicides and herbicide degradates and the personal-care product HHCB (fig. 21). The combination of atrazine and 2-hydroxyatrazine (detected in 18 percent of samples) was the most frequent, followed by atrazine and deethylatrazine (17 percent), and HHCB and chloroform (16 percent). Atrazine occurred at concentrations within one-tenth of a benchmark (appendix 4).

The 10 most frequently co-occurring mixtures in groundwater (fig. 21) include combinations of solvents, disinfection by-products, and the gasoline oxygenate MTBE. The combination of chloroform and PCE (detected in 6.4 percent of samples) was the most frequent, followed by PCE and TCE (4.6 percent) and chloroform and MTBE (4.2 percent). Chloroform, PCE, and TCE also occurred at concentrations within one-tenth of a benchmark (appendix 5). In general, the compounds detected most frequently as individual compounds in the environment often composed the most frequent unique mixtures.

Characterizing the mixtures with an assessment level attempts to alleviate any potential bias because of varying LRLs between different compounds and identifies the most frequently occurring unique mixtures of compounds at concentrations equal to or greater than $0.05 \mu \mathrm{g} / \mathrm{L}$. In general, detection frequency depends on the LRL for each compound monitored. Thus, different detection frequencies for compounds with different LRLs may not represent true differences in water quality, but rather they may only reflect differences in analytical sensitivity among the different compounds.

Using no assessment level for the 25 most frequently occurring compounds, the 10 most frequently co-occurring mixtures in surface water include combinations of herbicides and herbicide degradates and chloroform. The combination 

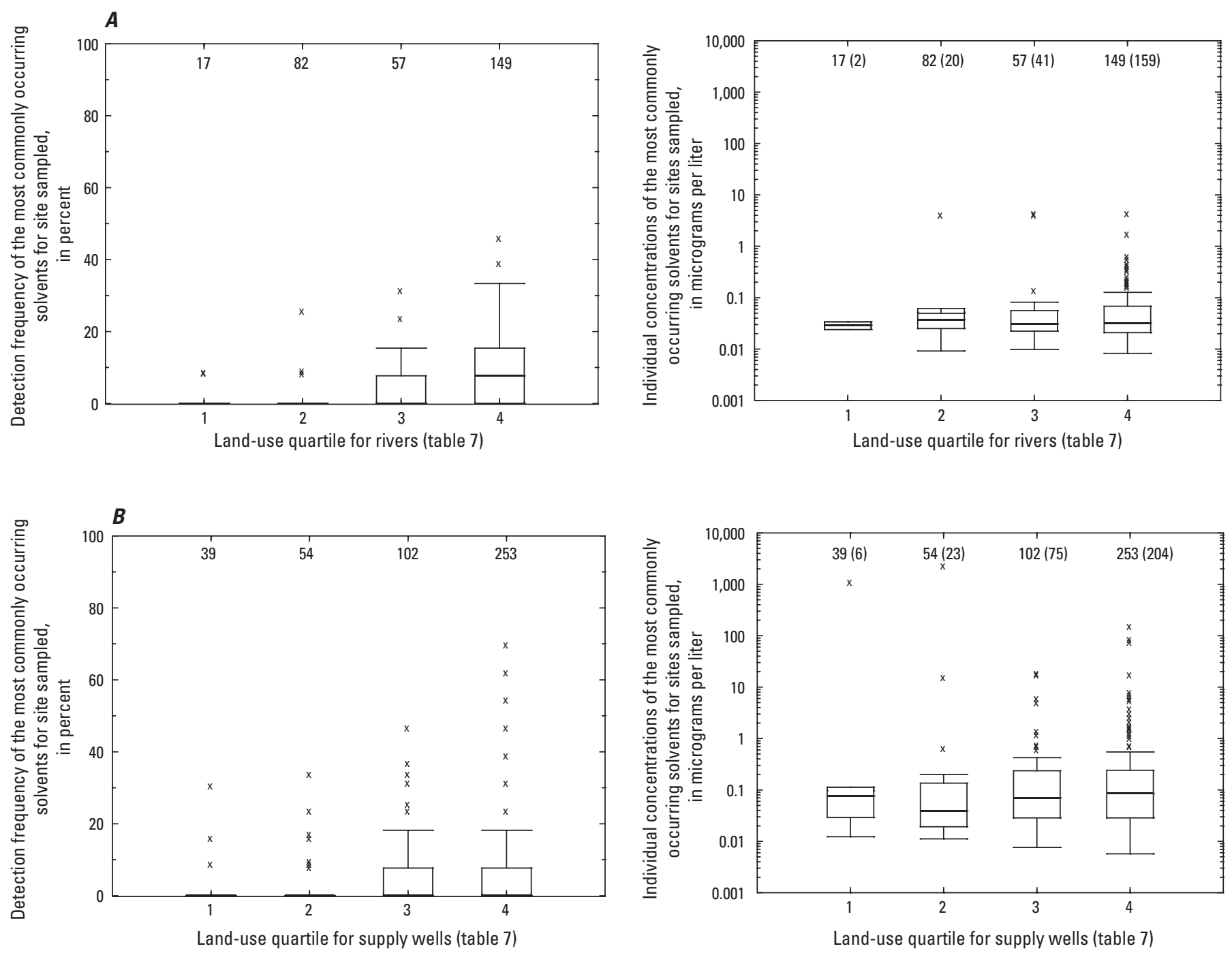

EXPLANATION

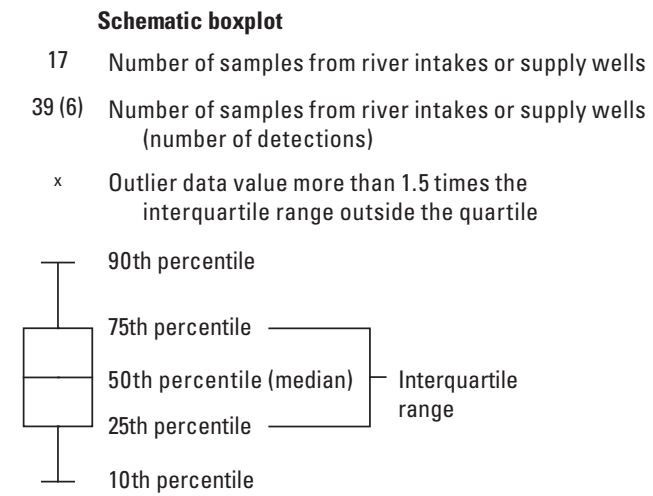

Figure 19. Occurrence and concentrations without assessment level of commonly occurring solvents within urban land-use quartiles for 2,016 river intakes and 112,099 supply wells considered to represent the national distribution of river intakes and supply wells, respectively, supplying community water systems for $A$, rivers and $B$, supply wells. 


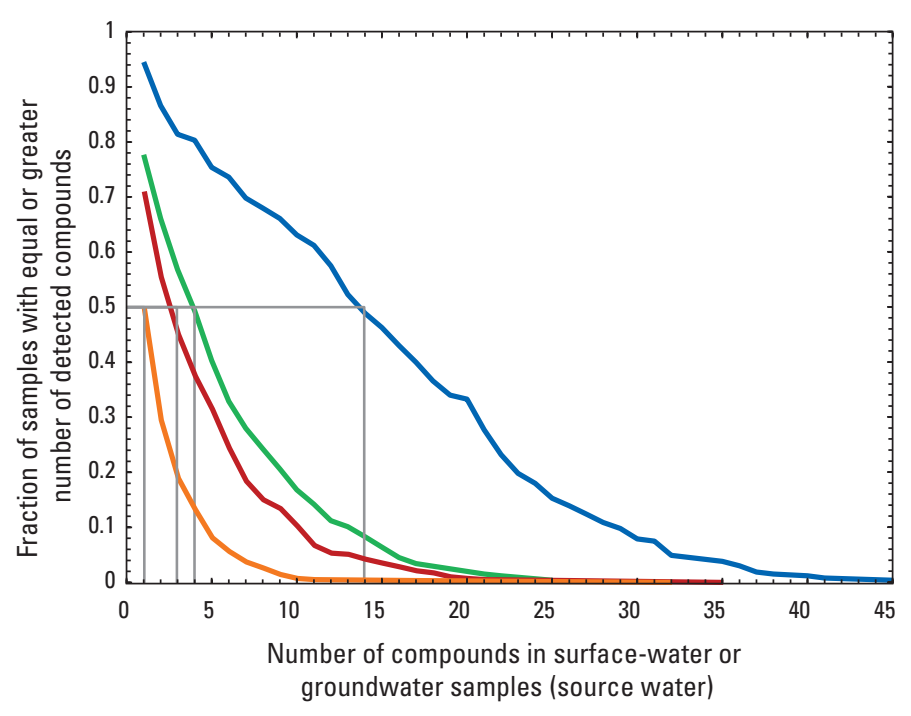

EXPLANATION

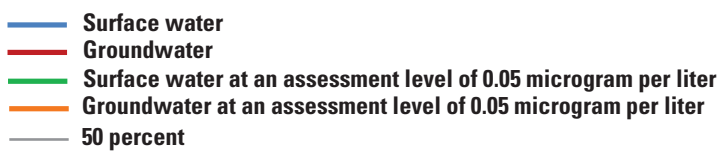

Figure 20. Distribution of the number of co-occurring anthropogenic organic compounds in surface water or groundwater samples collected during 2002-10 with and without a common assessment level.

of atrazine and deethylatrazine (59 percent) was the most frequent, followed by atrazine and simazine ( 57 percent) and atrazine and chloroform (53 percent) (fig. 22). Atrazine, simazine, and chloroform occurred at concentrations within onetenth of a benchmark (appendix 4). The 10 most frequently co-occurring mixtures in groundwater include combinations of herbicides and herbicide degradates, chloroform, and PCE. The combination of atrazine and deethylatrazine (26 percent) was the most frequent, followed by chloroform and deethylatrazine (about 20 percent) and atrazine and chloroform (about 17 percent) (fig. 22). Atrazine, chloroform, and PCE occurred at concentrations within one-tenth of a benchmark (appendix 5). Determining the commonly occurring compounds that were part of a unique mixture without an assessment level will characterize compounds that are found to frequently co-occur at low concentrations (micrograms per liter or parts per billion) in the environment. Some compounds, such as simazine, were frequently detected at low concentrations in both surface water and groundwater (median concentrations $0.02 \mu \mathrm{g} / \mathrm{L}$ and $0.006 \mu \mathrm{g} / \mathrm{L}$, respectively). In general, the compounds detected most frequently as individual compounds in the environment often composed the most frequent unique mixtures.

When evaluating unique mixtures of compounds without an assessment level, herbicide and herbicide degradates were among the most common compounds in the unique mixtures along with the disinfection by-product chloroform. This analysis begins to capture the significance of monitoring for degradates and, more specifically, for deethylatrazine, which is the degradate compound of atrazine. For both surface water and groundwater, the results indicate that the most common unique compounds in each category were atrazine and chloroform. The presence of atrazine could be attributed to its widespread use as an agricultural pesticide (Kingsbury and others, 2008), and the presence of chloroform could be attributed to leakage of chlorinated water from distribution systems used for drinking water or wastewater sewers, swimming pools, and spas; chlorinated water used to irrigate lawns, golf courses, parks, gardens, and other areas; septic systems; and regulated discharge of chlorinated waters to recharge facilities (Ivahnenko and Barbash, 2004; Carter and others, 2012). Lastly, 5 of the 10 most frequently co-occurring unique mixtures were the same in surface-water and groundwater samples (fig. 22). The similar mixtures include (1) atrazine and deethylatrazine, (2) atrazine and simazine, (3) atrazine and chloroform, (4) simazine and deethylatrazine, and (5) atrazine, simazine, and deethylatrazine. No mixtures were similar between surface water and groundwater when an assessment level was used in evaluating these co-occurring compounds (fig. 21). Because similar mixtures were identified in both surface water and groundwater without using an assessment level, future studies could be directed toward better understanding the toxicological importance of these unique mixtures.

\section{Occurrence of Herbicides and Herbicide Degradates}

In addition to the 265 compounds monitored at all sites, an additional 19 herbicides and herbicide degradates (3 herbicides and 16 degradates) were monitored at a subset of sites because the parent herbicide was likely to have been used in the study area and because of the higher potential for these degradates to persist at similar or greater concentrations relative to the parent compound (Thurman and others, 1992; Kalkhoff and others, 1998). The additional 19 herbicides and herbicide degradates (appendix 1) were analyzed in samples from 8 river intakes and at 118 supply wells. The 3 additional parent herbicides are dimethenamid, flufenacet, and propachlor. Degradates include dimethenamid ethane sulfonic acid (ESA), dimethenamid oxanilic acid, flufenacet ESA, flufenacet oxanilic acid, propachlor ESA, and propachlor oxanilic acid. Some of the additional herbicide degradates are degradates of three parent herbicides included as part of the 265 compounds monitored at all sites. These include (1) alachlor ESA 2nd amide, alachlor ESA, alachlor oxanilic acid, and alachlor sulfynilacetic acid (degradates of alachlor); (2) acetochlor oxanilic acid, acetochlor sulfynilacetic acid, acetachlor ESA, acetochlor/metolachlor ESA 2nd amide (degradates of acetachlor); and (3) metolachlor ESA and metolachlor oxanilic acid (degradates of metolachlor).

Two additional degradates of alachlor (2,6-diethylaniline and 2-chloro-2,6-diethylacetanilide) were analyzed as part of the 265 compounds monitored at all sites. Similarly, atrazine and four of its degradates (2-hydroxyatrazine, deethylatrazine, 


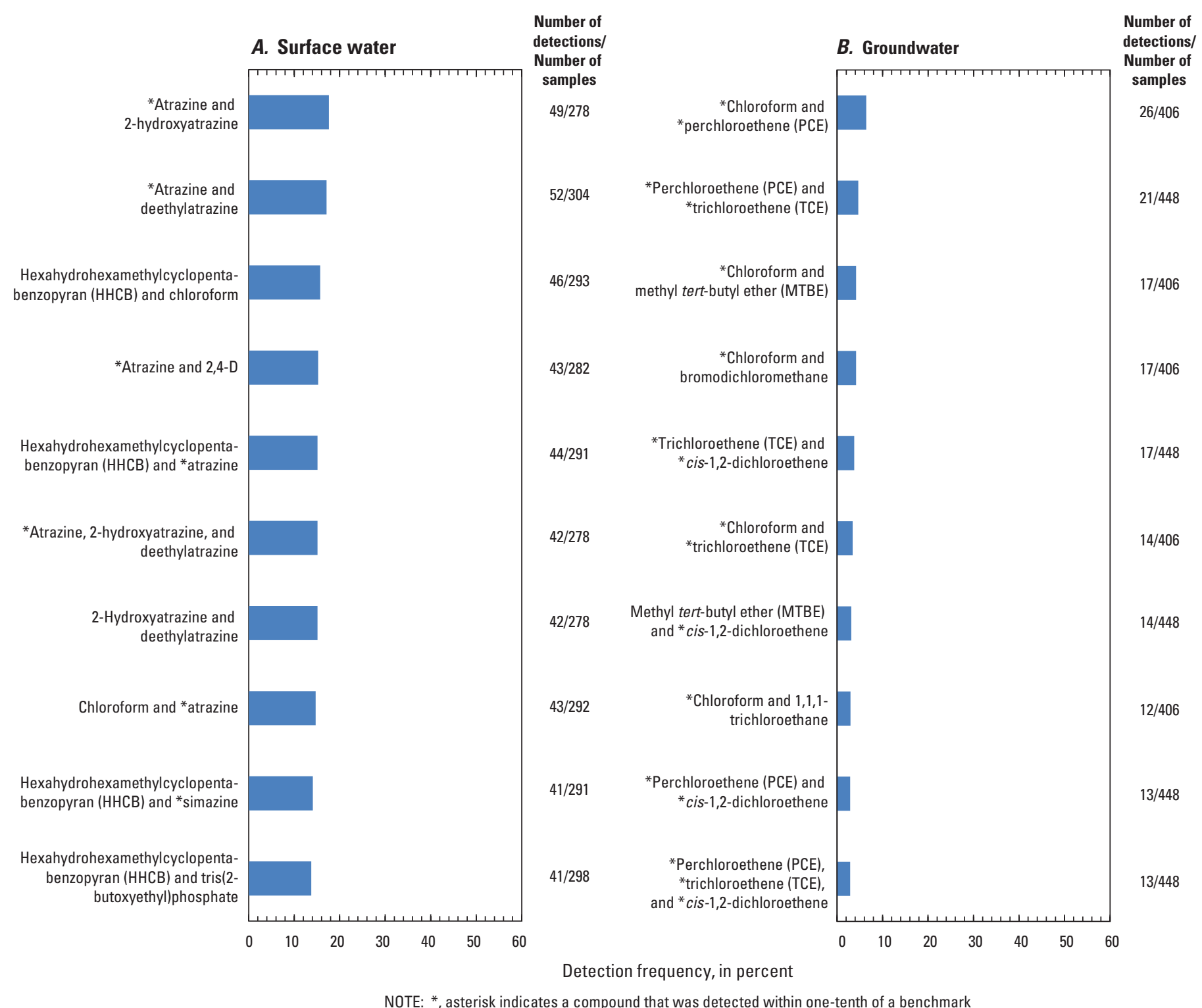

Figure 21. Ten most frequently co-occurring compounds evaluated with an assessment level of 0.05 microgram per liter in samples collected from $A$, surface water during 2002-10 and B, groundwater during 2002-09.

deethyldeisopropylatrazine, and deisopropylatrazine) were analyzed in samples collected at all sites. In total, data from 7 parent herbicides and 22 herbicide degradates were available for evaluation at 8 river intakes and 118 supply wells. These 7 parent herbicides are classified as analides (flufenacet), amides (dimethenamid), chloroacetanilides (alachlor, acetochlor, metolachlor, and propachlor), and triazine (atrazine).

The summed concentrations of the degradates compared to concentrations of the seven respective parent herbicides in surface water and groundwater are shown in figure 23. The summed concentrations of the four atrazine degradates were similar to or slightly less than atrazine concentrations in surface water and were similar to or greater than atrazine concentrations in groundwater (fig. 23).
The summed concentrations of chloroacetanilide herbicide degradates in both surface water and groundwater were greater than the parent herbicide concentrations (fig. 23). In surface water, both the parent and degradates of chloroacetanilides commonly were present in samples; however, degradates of alachlor and acetochlor were occasionally present without their parent. This differs from groundwater, wherein degradates of metolachlor and alachlor were almost solely present without their parent. This may be due to the parent compound being present in groundwater for a longer period of time allowing it to more completely degrade. Acetochlor sulfynilacetic acid and alachlor sulfynilacetic acid were not detected in groundwater samples but were detected in surface-water samples. Propachlor and 


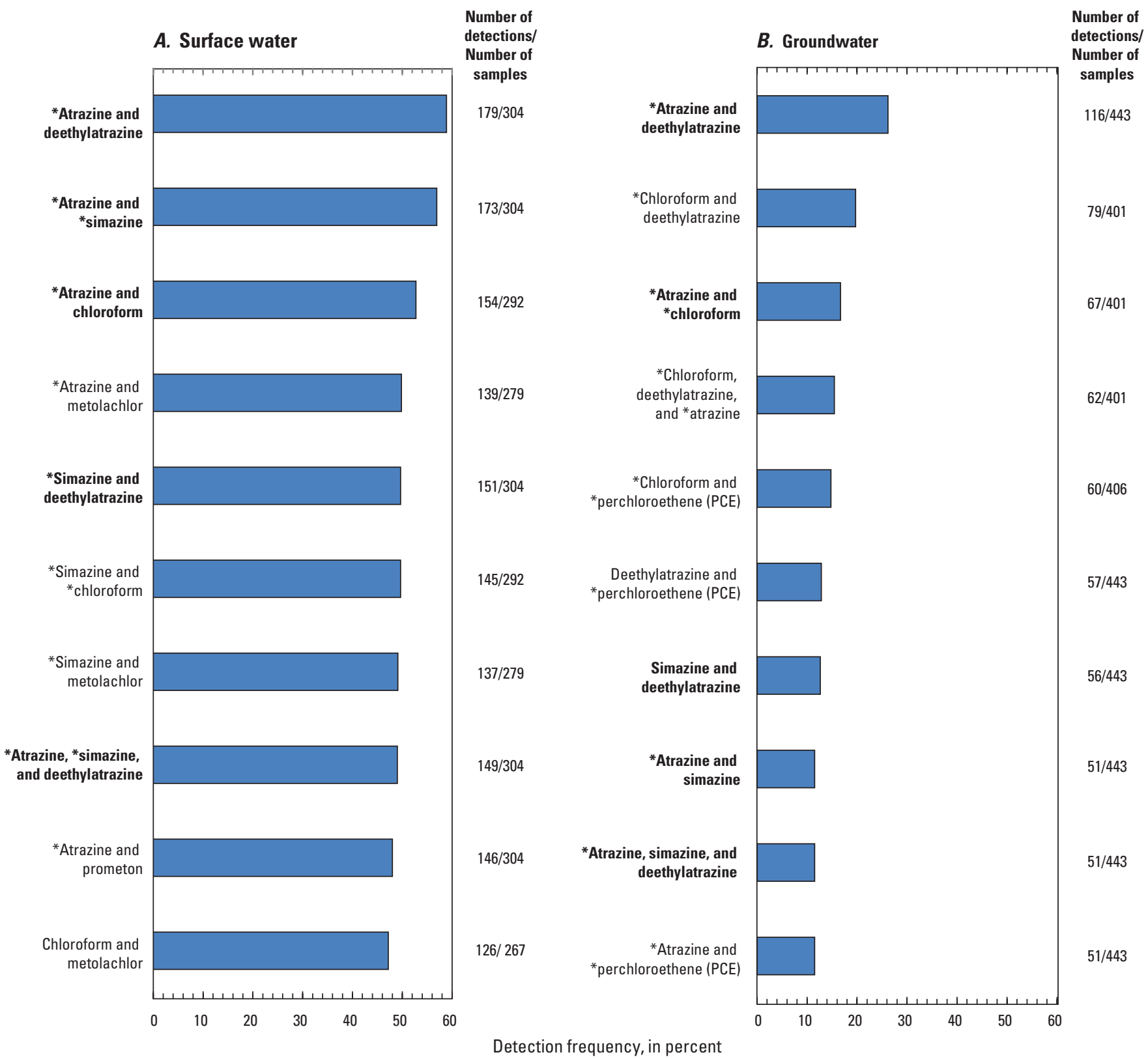

NOTE: Bold font indicates similar mixtures for surface water and groundwater at no assessment level;

*, asterisk indicates a compound that was detected within one-tenth of a benchmark

Figure 22. Ten most frequently co-occurring compounds evaluated without an assessment level in samples collected from $A$, surface water during 2002-10 and $B$, groundwater samples during 2002-09.

its degradates were the only chloroacetanilides that were not detected in either surface-water or groundwater samples.

Dimethenamid and flufenacet, along with their degradates, were infrequently detected (in about 1 percent of samples) in surface water or groundwater. Degradates of dimethenamid and the parent occurred at two surface-water sites and were never detected in groundwater. The degradates of flufenacet occurred in surface-water samples without the parent.
Understanding the persistence and degradation of parent compounds is important because herbicide degradates have been reported to have, at times, similar or greater concentrations compared to the parent compound in a sample (Hopple and others, 2009). The toxicity to humans for many of these degradate products is largely unknown and thus points to the importance of monitoring these compounds (both the parents and degradates) in the environment (Toccalino and Hopple, 2010). In addition, the co-occurrence of parent herbicides, 


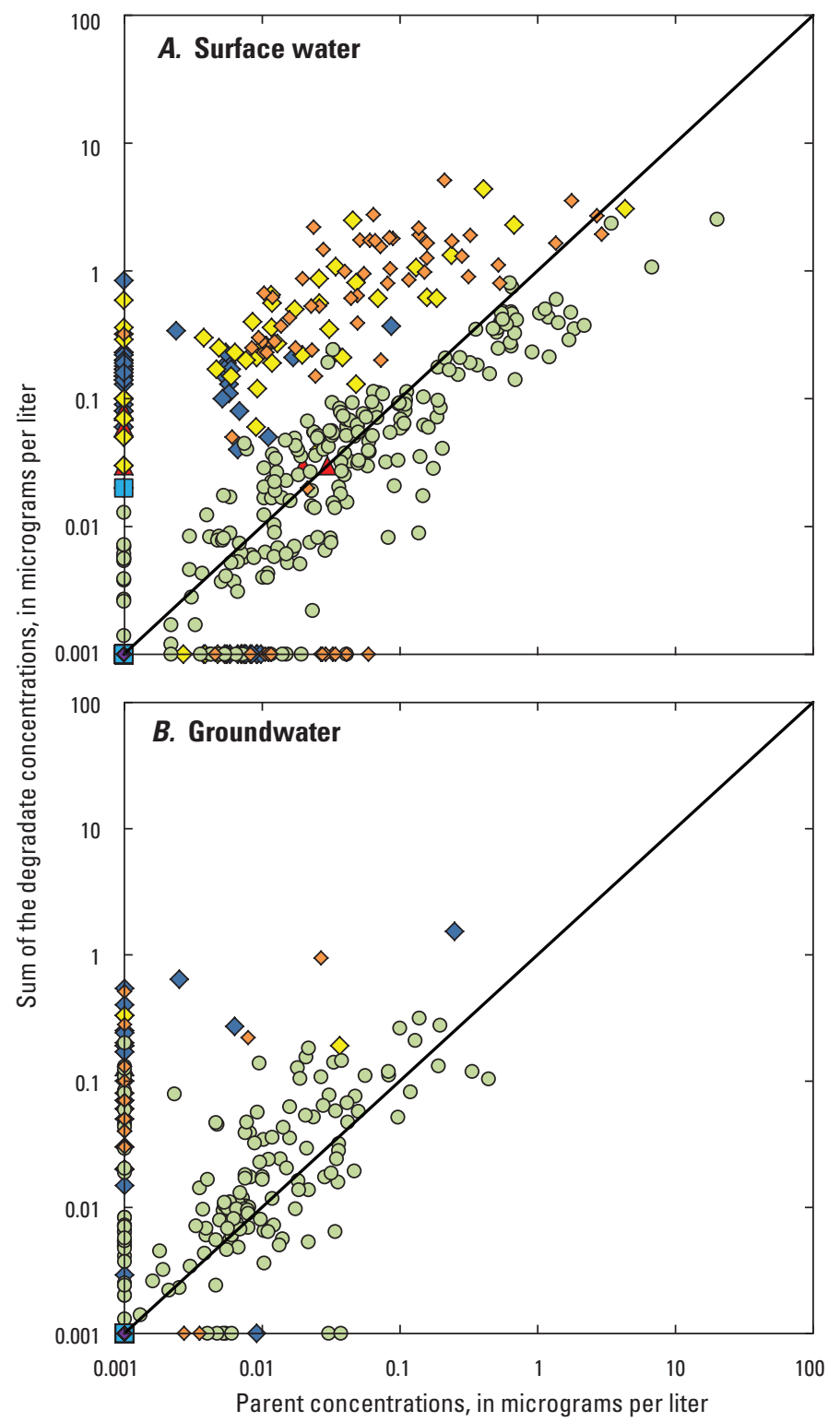

EXPLANATION

[The number in parentheses is the number of degradates monitored for each parent compound]

$\begin{array}{lll}\text { Anilide } & \text { Chloroacetanilide } & \text { Triazine } \\ \square \text { Flufenacet (2) } & \diamond \text { Alachlor (6) } & \text { ○ Atrazine (4) } \\ \text { Amide } & \diamond \text { Acetochlor (4) } & \\ \triangle \text { Dimethenamid (2) } & \diamond \text { Metolachlor (2) } & \end{array}$

Figure 23. Relation between summed concentrations of herbicide degradates and concentrations of the parent herbicide for $A$, surface water, and $B$, groundwater. primarily atrazine, metolachlor, acetochlor, and alachlor along with their respective degradates is important to monitor as these were detected in source waters of CWSs supplied by surface water. Similarly, degradates of metolachlor, alachlor, and atrazine are especially important to monitor for CWSs supplied by groundwater as they often occur without their parent.

\section{Summary and Conclusions}

Drinking water delivered by community water systems (CWSs) comes from one or both of two sources: surface water and groundwater. Source water is raw, untreated water used by CWSs and is usually treated before distribution to consumers. Characterizing sources of drinking water is important to better understand what compounds may enter the treatment process either through natural occurrence in the environment, animal activity, or as a result of anthropogenic effects. Beginning in 2002, the U.S. Geological Survey's (USGS) National WaterQuality Assessment Program initiated Source Water-Quality Assessments at select CWSs across the United States. The primary emphasis of Source Water-Quality Assessments is to characterize the occurrence of a large number of anthropogenic organic compounds that are predominantly unregulated by the U.S. Environmental Protection Agency in sources of drinking water.

As part of this effort, source-water samples from CWSs were collected during 2002-10 from 20 surface-water sites (river intakes) and during 2002-09 from 448 groundwater sites (supply wells). Rivers were sampled approximately 16 times over the course of a year, and supply wells were sampled once. Samples collected from all surface-water and groundwater sites were analyzed for 265 anthropogenic organic compounds. An additional 3 herbicides and 16 herbicide degradates were analyzed in samples collected from sites in areas where these compounds likely had been used. Of the 265 compounds monitored, 37 compounds have an established U.S. Environmental Protection Agency (EPA) Maximum Contaminant Level (MCL) for drinking water, 123 have USGS Health-Based Screening Levels (HBSLs), and 29 are included on the EPA Contaminant Candidate List 3 (CCL3). All compounds detected in source water were evaluated both with and without an assessment level and were grouped into 13 categories (hereafter termed as "use groups") based on their primary use or source.

The CWS sites were characterized in a national context using an extract of the EPA Safe Drinking Water Information System to develop spatially derived and system-specific ancillary data. CWS information is contained in the Public Supply Database, which includes 2,016 active river intakes and 112,099 active supply wells. Ancillary variables including population served, watershed size, land use, population density, and recharge were characterized for each of the watersheds for river intakes and contributing areas for supply wells. 
A total of 313 surface-water samples were collected from 20 river intakes. Seventy-one compounds from 12 of the 13 use groups were found to commonly occur (detected in greater than or equal to 1 percent of samples using an assessment level of 0.05 microgram per liter $(\mu \mathrm{g} / \mathrm{L})$ or when a compound was detected in greater than or equal to 10 percent of samples without an assessment level) indicating a wide variety of sources and pathways to these rivers and highlighting the importance of source-water protection strategies. Using a common assessment level of $0.05 \mu \mathrm{g} / \mathrm{L}, 15$ of the 265 AOCs were detected in more than 10 percent of surface-water samples. Hexahydrohexamethylcyclopentabenzopyran (HHCB) was the most commonly occurring compound (29.5 percent) followed by chloroform (27.3 percent), atrazine (27.3 percent), tri(2-butoxyethyl)phosphate (23.8 percent), methyl tert-butyl ether (MTBE) (20.9 percent), and 2,4-D (20.4 percent). Most concentrations without an assessment level (63 percent) were less than $0.05 \mu \mathrm{g} / \mathrm{L}$.

A total of 448 groundwater samples were collected from supply wells that were sampled once during 2002-09 as part of 30 independent groundwater studies. Each independent groundwater study sampled about $15 \mathrm{CWS}$ wells. Twenty-eight compounds from 7 of the 13 use groups commonly occurred indicating that a wide variety of sources and pathways exist for these compounds to reach these wells and highlighting the importance of wellhead protection strategies. Using the common assessment level of $0.05 \mu \mathrm{g} / \mathrm{L}, 3$ of the 265 AOCs were detected in more than 10 percent of groundwater samples. Chloroform was the most commonly occurring compound (23.9 percent) followed by MTBE (12.3 percent) and perchloroethene (11.6 percent). These compounds are among the most frequently occurring compounds found in national ambient resources assessment conducted by the USGS. This may indicate that compounds found to frequently occur in broad-scale resource assessments also may be present in source water. Most concentrations without an assessment level (61 percent) were less than $0.05 \mu \mathrm{g} / \mathrm{L}$.

About one-half the 265 compounds monitored (122) were detected in both surface-water and groundwater samples without using an assessment level. This highlights the importance of monitoring source water supplied by both water types to identify compounds that may occur most frequently, especially those compounds that are unregulated. About 28 percent ( 73 of 265) of the compounds were never detected in either type of water samples. Fourteen percent (36) of compounds were detected only in surface-water samples, whereas 13 percent (34) were detected only in groundwater samples. Many compounds that were detected frequently were found to occur in both water types, further indicating that these compounds have a variety of sources and pathways to enter water supplies.

A more diverse suite of compounds was detected in surface water than groundwater. However, the herbicides and herbicide degradate group was the most frequent group of compounds detected in both surface water and groundwater. Sixty-five of the most commonly occurring compounds were detected in one or more samples from both surface water and groundwater. For commonly occurring compounds detected in both water types, the detection frequency was higher for surface-water samples than groundwater samples; however, concentrations were not significantly different (rank-sum test; $p$-value $=0.4292$ ). Different patterns in concentrations were observed for analyses of individual use groups. For example, herbicides and herbicide degradates and personal-care products were detected more frequently and concentrations were greater in surface-water samples than in groundwater samples. Some solvents and disinfection by-products were detected more frequently in surface water, whereas others were detected more frequently in groundwater, and yet concentrations for both use groups were larger in groundwater. This highlights the importance of understanding the sources and pathways for a compound to enter source water as well as the compound's physical and chemical properties.

Four compounds (acetochlor, diuron, MTBE, and metolachlor) in surface water and three compounds (1,1-dichloroethane, diuron, and MTBE) in groundwater that commonly occurred are included on the CCL3. The gasoline oxygenate MTBE was detected more frequently in surface water (24 percent) than in groundwater (15 percent). Similarly, the herbicide diuron was detected more frequently in surface water (35 percent) than in groundwater ( 9 percent). The frequent occurrence without an assessment level of these two compounds in surface-water and groundwater samples may warrant consideration in future monitoring programs.

Human-health benchmarks (MCLs for regulated compounds and HBSLs for unregulated compounds) were available for more than one-half the compounds (160 of the 265) analyzed in this study. Fifty-eight percent (41 of 71) of the commonly occurring compounds in surface water have a human-health benchmark to which concentrations can be compared: 19 have MCLs and 22 have HBSLs. Five compounds (4 herbicides and herbicide degradates and 1 insecticide) in surface water had concentrations that were greater than or within one-tenth of a benchmark. No commonly occurring compounds had an annual mean concentration greater than or within one-tenth of the benchmark value. Eighty-three percent (24 of 28) of the most commonly occurring compounds in groundwater have a human-health benchmark for which concentrations can be compared: 14 have MCLs and 10 have HBSLs. Nine compounds (1 disinfection by-product, 1 herbicide, 1 organic synthesis compound, and 6 solvents) had concentrations in groundwater that were greater than or within one-tenth of a benchmark. Perchloroethene and trichloroethene were the only compounds with concentrations in groundwater greater than the benchmark value. Although more compounds were detected in surface water and occurred more frequently than in groundwater, the number of compounds detected within at least one-tenth of a benchmark was roughly double in groundwater (9) than rivers (5).

Thirty-two of the commonly occurring compounds in surface water and groundwater do not have a human-health benchmark. Of these, 17 were detected in 10 percent or more source-water samples from either water type. Two compounds 
were found to occur in more than 10 percent of samples in both water types: deethylatrazine and MTBE. The frequent occurrence of these two compounds may warrant the development of appropriate toxicity information, which would allow the ability to calculate an HBSL value to which concentration data could be compared. Lacking this information, it is not possible to interpret results for these compounds in a humanhealth context.

To put results from this study into context with the national distribution of river intakes and supply wells used by CWSs, sites were grouped into the respective national population of land-use quartiles. The increase in compound occurrence with increasing urban and agricultural land use in the watershed or contributing area was more evident for rivers than for supply wells. For rivers, the median detection frequency of the most commonly detected compounds increased for each land-use quartile, with more than 13 and 21 percent compound occurrence in samples from watersheds in the third and fourth quartiles, respectively, of urban and agricultural land use combined. The third and fourth quartiles represent rivers with 17 percent or more urban and agricultural land use within their watershed. In groundwater, the difference in occurrence between the second, third, and fourth quartiles was small with median detection frequencies of about 3 percent in each.

The increase in detection frequency of herbicides and herbicide degradates with increasing agricultural land use was more evident for rivers than for supply wells. For rivers, the median detection frequency increased for each quartile, with more than 30 and 36 percent in samples from watersheds in the third and fourth quartiles of agricultural land use, respectively (collectively representing rivers with 9.1 percent or more agricultural land use within their watershed). Similarly, the median detected concentrations increased as the amount of agricultural land use increased; however, concentrations were low with median concentrations in the fourth quartile of about $0.03 \mu \mathrm{g} / \mathrm{L}$. The increased detection frequency from one quartile to the next indicates that there is a strong correlation between the occurrence of commonly occurring compounds, especially herbicides and herbicide degradates, and the percentage of urban and (or) agricultural land use within the watershed. The occurrence of solvents did not change substantially with increasing urban land use for rivers or supply wells.

Basic co-occurrence analyses were completed with and without an assessment level. Considering all detections in surface water without an assessment level, approximately 86 percent of source-water samples contained two or more compounds, and 50 percent of samples contained at least 14 compounds. Considering all detections in groundwater without an assessment level, 50 percent of samples contained at least three compounds. Using an assessment level of $0.05 \mu \mathrm{g} / \mathrm{L}, 50$ percent of samples contained at least 4 compounds in surface water and 1 compound in groundwater.

Characterizing the most frequently occurring unique mixtures was done with and without an assessment level. Summarizing mixtures with an assessment level attempts to alleviate any potential bias because of varying laboratory reporting levels between different compounds and identifies the most frequently occurring unique mixtures of compounds at concentrations greater than or equal to $0.05 \mu \mathrm{g} / \mathrm{L}$. The 10 most frequently co-occurring mixtures, using an assessment level, in surface water include atrazine and 2-hydroxyatrazine (18 percent), atrazine and deethylatrazine (17 percent), and HHCB and chloroform (16 percent). The 10 most frequently co-occurring mixtures in groundwater include chloroform and perchloroethene (6.4 percent), perchloroethene and trichloroethene ( 4.6 percent), and chloroform and MTBE (4.2 percent). In general, the compounds detected most frequently as individual compounds in the environment often composed the most frequent unique mixtures.

Comparing the compounds that were part of a unique mixture without an assessment level characterizes compounds that frequently co-occur at low concentrations (micrograms per liter or parts per billion) in the environment. Using no assessment level, the 10 most frequently co-occurring mixtures in surface water include atrazine and deethylatrazine (59 percent), atrazine and simazine (57 percent), and atrazine and chloroform (53 percent). The 10 most frequently cooccurring mixtures in groundwater include atrazine and deethylatrazine (26 percent), chloroform and deethylatrazine (about 20 percent), and atrazine and chloroform (about 17 percent). This analyses captures the significance of monitoring pesticide degradates and, more specifically, deethylatrazine.

Five of the 10 most frequently co-occurring unique mixtures in both surface water and groundwater were the same: atrazine and deethylatrazine, atrazine and chloroform, simazine and deethylatrazine and simazine, atrazine and simazine, and atrazine, simazine, and deethylatrazine. No mixtures were similar between surface water and groundwater when an assessment level was used. Because similar mixtures were identified in both surface water and groundwater without using an assessment level, future studies could be directed toward better understanding the toxicological importance of these unique mixtures.

In addition to the 265 compounds monitored at all sites, an additional 19 herbicides and herbicide degradates ( 3 herbicides and 16 degradates) were monitored at a subset of sites because the parent herbicide was likely to have been used in the study area and because of the higher potential for these degradates to persist at similar or greater concentrations relative to the parent compound. The additional 19 herbicides and herbicide degradates were monitored at 8 river intakes and at 118 supply wells.

Concentrations of the summed concentrations of degradates were compared to the concentrations of parent herbicides in surface water and groundwater. In surface water, the summed concentrations of the four atrazine degradates (2-hydroxyatrazine, deethylatrazine, deethyldeisopropylatrazine, and deisopropylatrazine) were similar to or slightly less than the parent compound. In groundwater, the summed concentrations were similar to or greater than the parent compound. The summed concentrations of 14 chloroacetanilide 
herbicide (alachlor, acetochlor, metolachlor, and propachlor) degradates in both surface water and groundwater was greater than the parent herbicide. In surface water, degradates of alachlor and acetochlor were occasionally present without their parent compounds. In groundwater, degradates of metolachlor and alachlor were almost solely present without their parent compounds. Acetochlor sulfynilacetic acid and alachlor sulfynilacetic acid were detected in surface water but not groundwater. Propachlor and the respective degradates were the only chloroacetanilides that were never detected in either surface water or groundwater. Dimethenamid and flufenacet, along with their degradates, were infrequently detected (about 1 percent) in surface water and groundwater.

The toxicity to humans for many of these degradate products is largely unknown and thus points to the importance of monitoring these compounds (both the parents and degradates) in the environment. In addition, the co-occurrence of parent herbicides, primarily atrazine, metolachlor, acetochlor, and alachlor, along with their degradates is important because these were detected in source waters of CWSs supplied by surface water. Similarly, degradates of metolachlor, alachlor, and atrazine are especially important for CWSs supplied by groundwater as they often occur without their parent.

This study highlights the importance of anthropogenic organic compounds in source water of select CWSs in the United States by characterizing the occurrence of the anthropogenic organic compounds in surface water and groundwater samples. Compound concentrations and occurrence are summarized and evaluated in a human-health context, when possible. Additionally, compounds found to co-occur as mixtures for both rivers and groundwater highlight the significance of low-level compound co-occurrence.

\section{References Cited}

Agency for Toxic Substances and Disease Registry (ATSDR), 1992a, Toxicological profile for 1,2,3-trichloropropane, accessed January 17, 2007, at http://www.atsdr.cdc.gov/ toxprofiles $/$ tp.asp $?$ id $=912 \&$ tid $=186$.

Agency for Toxic Substances and Disease Registry (ATSDR), 1992b, Toxicological profile for 2-hexanone, accessed February 16, 2007, at http://www.atsdr.cdc.gov/toxprofiles/ tp.asp? id $=738 \&$ tid $=134$.

Agency for Toxic Substances and Disease Registry, 1997, Toxicological profile for chloroform: U.S. Department of Health and Human Services, Public Health Service, Agency for Toxic Substances and Disease Registry, 293 p, accessed May 16, 2013, at http://www.atsdr.cdc.gov/toxprofiles/ tp.asp? $i d=53 \&$ tid $=16$.
Agency for Toxic Substances and Disease Registry, 2004, Guidance manual for the assessment of joint toxic action of chemical mixtures: U.S. Department of Health and Human Services, Agency for Toxic Substances and Disease Registry, May 2004, 107 p., accessed May 16, 2013, at http:// www.atsdr.cdc.gov/interactionprofiles/IP-ga/ipga.pdf.

Alexander, R.B., Smith, R.A., Focazio, M.J., and Horn, M.A., 1999, Source-area characteristics of large public surfacewater supplies in the conterminous United States-An information resource for source-water assessment: U.S. Geological Survey Open-File Report 99-248.

Api, A.M., and Ford, R.A., 1999, Evaluation of the oral subchronic toxicity of HHCB $(1,3,4,6,7,8$-hexahydro4,6,6,7,8,8-hexamethylcyclopenta- $\gamma$-2-benzopyran) in the rat: Toxicology Letters, v. 111, no. 1-2, p. 143-149. (Also available at $h t t p: / / d x . d o i . o r g / 10.1016 / S 0378-$ 4274(99)00175-7.)

Barbash, J.E., and Reinhard, M., 1989, Abiotic dehalogenation of 1,2-dichloroethane and 1,2-dibromoethane in aqueous solution containing hydrogen sulphide: Environmental Science and Technology, v. 23, no. 11, p. 1,349-1,358. (Also available at: $h t t p: / / d x$.doi.org/10.1021/es00069a004.)

Bender, D.A., Zogorski, J.S., Halde, M.J., and Rowe, B.L., 1999, Selection procedure and salient information for volatile organic compounds emphasized in the National WaterQuality Assessment Program: U.S. Geological Survey Open-File Report 99-182, 32 p. (Also available at $h t t p: / /$ pubs.er.usgs.gov/publication/ofr99182.)

Bender, D.A., Delzer, G.C., Price, C.V., and Zogorski, J.S., 2009, Occurrence of volatile organic compounds in selected urban streams in the United States, 1995-2003: U.S. Geological Survey Scientific Investigations Report 2009-5203, 87 p. (Also available at $h t t p: / / p u b s . u s g s . g o v /$ sir/2009/5203/.)

Bester, Kai, 2004, Retention characteristics and balance assessment for two polynuclear musk fragrances (HHCB and AHTN) in a typical German sewage treatment plant: Chemosphere, v. 57, no. 8, p. 863-870. (Also available at http://dx.doi.org/10.1016/j.chemosphere.2004.08.032.)

Bradley, P.M., Chapelle, F.H., and Landmeyer, J.E., 2001, Effect of redox conditions on MTBE biodegradation in surface water sediments: Environmental Science and Technology, v. 35 , no. 23 , p. 4,643-4,647. (Also available at $h t t p: / /$ pubs.acs.org/doi/abs/10.1021/es010794x.)

Budavari, Susan, ed., 1989, The Merck Index: Rahway, N.J., Merck and Company, Inc. [variously paged]. 
Budavari, Susan, ed., 1996, The Merck Index (12th ed.): Whitehouse Station, N.J., Merck and Company, Inc. [variously paged].

Bureau of the Census, 2001, Census of population and housing, 2000-Public Law 94 -171 data (United States) (machine readable data files): Washington, D.C., The Bureau (producer and distributor).

California Environmental Protection Agency, 1999, Final prioritized candidate chemicals under consideration for carcinogenicity evaluation - Fifty-four chemicals within batch \#3: accessed January 17, 2007, at http://www.oehha.ca.gov/ prop65/pdfffbatch3.pdf.

CambridgeSoft Corporation, 2010, Chembiofinder.com database: accessed July 30, 2010, at $h t t p: / / w w w . c a m b r i d g e s o f t$. $\mathrm{com} /$.

Carpenter, D.O., Arcaro, K., and Spink, D.C., 2002, Understanding the human health effects of chemical mixtures: Environmental Health Perspectives, v. 110, Supplement 1, p. 25-42. (Also available at $h t t p: / / w w w . j s t o r . o r g /$ stable/3455232.)

Carter, J.M., Grady, S.J., Delzer, G.C., Koch, Bart, and Zogorski, J.S., 2006, Occurrence of MTBE and other gasoline oxygenates in CWS source waters: Journal of the American Water Works Association, v. 98, no. 4, p. 91-104.

Carter, J.M., Kingsbury, J.A., Hopple, J.A., and Delzer, G.C., 2010, Concentration data for anthropogenic organic compounds in groundwater, surface water, and finished water of selected community water systems in the United States, 2002-10: U.S. Geological Survey Data Series 544, 36 p., accessed July 3, 2012, at http://pubs.usgs.gov/ds/544/.

Carter, J.M., Moran, M.J., Zogorski, J.S., and Price, C.V., 2012, Factors associated with sources, transport, and fate of chloroform and three other trihalomethanes in untreated groundwater used for drinking water: Environmental Science and Technology, v. 46, p. 8,189-8,197. (Also available at $h t t p: / / d x$.doi.org/10.1021/es301839p.)

Chemicalland21, 2010, Tolutraizole, accessed July 30, 2010, at http://www.chemicalland21.com/specialtychem/finechem/ TOLUTRIAZOLE.htm.

Cohen, D.B., Gilmore, D., Fischer, C., Bowes, G., 1983, Water quality and pesticides-1,2-Dichloropropane $(1,2-\mathrm{D})$ and 1,3-dichloropropene (1,3-D): Sacramento, Calif., California State Water Resources Control Board, Water Quality and Pesticides Special Projects Report No. 83-8SP.
Connor, B.F., Rose, D.L., Noriega, M.C., Murtagh, L.K., and Abney, S.R., 1998, Methods of analysis by the U.S. Geological Survey National Water Quality Laboratory-Determination of 86 volatile organic compounds in water by gas chromatography/mass spectrometry, including detections less than reporting limits: U.S. Geological Survey OpenFile Report 97-829, 78 p., accessed May 16, 2013, at http:// nwql.usgs.gov/Public/pubs/OFR97-829/OFR97-829.html.

Cozzarelli, I.M., Baedecker, M.J., Eganhouse, R.P., and Goerlitz, D.F., 1994, The geochemical evolution of low-molecular-weight organic acids derived from the degradation of petroleum contaminants in groundwater: Geochimica et Cosmochimica Acta, v. 58, no. 2, p. 863-877. (Also available at $h t t p: / / d x$.doi.org/10.1016/0016-7037(94)90511-8.)

Cozzarelli, I.M., Eganhouse, R.P., and Baedecker, M.J., 1990, Transformation of monoaromatic hydrocarbons to organic acids in anoxic groundwater environment: Environmental Geology, v. 16, no. 2, p. 135-141. (Also available at $h t t p: / /$ dx.doi.org/10.1007/BF01890379.)

Delzer, G.C., and Hamilton, P.A., 2007, National Water-Quality Assessment Program - Source Water-Quality Assessments: U.S. Geological Survey Fact Sheet 2007-3069, 2 p., accessed May 16, 2013, at http://pubs.usgs.gov/ $f_{s} / 2007 / 3069 /$.

DeSimone, L.A., 2009, Quality of water from domestic wells in principal aquifers of the United States, 1991-2004: U.S. Geological Survey Scientific Investigations Report 2008-5227, 139 p. (Also available at http://pubs.usgs.gov/ sir/2008/5227/.)

DeWalle, F.B., Kalman, D.A, Norman, D., Sung, J., Plews, G., 1985, Determination of toxic chemicals in effluent from household septic tanks: Washington, D.C., U.S. Environmental Protection Agency Technical Report 600/2-85/050.

Egli, Christine; Tschan, Thomas; Scholtz, Rudolf; Cook, A.M.; and Leisinger, Thomas, 1988, Transformation of tetrachloromethane to dichloromethane and carbon dioxide by acetobacterium woodii: Applied and Environmental Microbiology, v. 54 , no. 11 , p. $2,819-2,824$

Furlong, E.T., Anderson, B.D., Werner, S.L., Soliven, P.P., Coffey, L.J., and Burkhardt, M.R., 2001, Methods of analysis by the U.S. Geological Survey National Water Quality Laboratory-Determination of pesticides in water by graphitized carbon-based solid-phase extraction and high-performance liquid chromatography/mass spectrometry: U.S. Geological Survey Water-Resources Investigations Report 01-4134, 73 p. (Also available at http://nwql.usgs. gov/Public/pubs/WRIR01-4134.html.) 
Gilliom, R.J., Alexander, R.B., and Smith, R.A., 1985, Pesticides in the Nation's rivers, 1975-1980, and implications for future monitoring: U.S. Geological Survey Water-Supply Paper 2271, 26 p. (Also available at $h t t p: / / p u b s . e r . u s g s$. gov/publication/wsp2271.)

Gilliom, R.J., Barbash, J.E., Crawford, C.G., Hamilton, P.A., Martin, J.D., Nakagaki, N., Nowell, L.H., Scott, J.C., Stackelberg, P.E., Thelin, G.P., and Wolock, D.M., 2006, The quality of our Nation's waters-Pesticides in the Nation's streams and ground water, 1992-2001: U.S. Geological Survey Circular 1291, 172 p. (Also available at http://pubs. usgs.gov/circ/2005/1291/.)

Glassmeyer, S.T., Furlong, E.T., Kolpin, D.W., Cahill, J.D., Zaugg, S.D., Werner, S.L., Meyer, M.T., and Kryak, D.D., 2005, Transport of chemical and microbial compounds from known wastewater discharges-Potential for use as indicators of human fecal contamination: Environmental Science and Technology, v. 39, no. 14, p. 5,157-5,169. (Also available at $h t t p: / / d x$.doi.org/10.1021/es048120k.)

Haag, W.R., and Mill, T., 1988, Effect of a subsurface sediment on hydrolysis of haloalkanes and epoxides: Environmental Science and Technology, v. 22, no. 6, p. 658-663. (Also available at $h t t p: / / d x$.doi.org/10.1021/es00171a007.)

Halling-Sørensen, B., Nielson, S.N., Lanzky, P.F., Ingerslev, F., Holten Lutzhøft, H.C., and Jørgensen, S.E., 1998, Occurrence, fate and effects of pharmaceutical substances in the environment-A review: Chemosphere, v. 36, p. 357-393. (Also available at $h t t p: / / d x$.doi.org/10.1016/S00456535(97)00354-8.)

Halogenated Solvents Industry Alliance, 2010, Uses: accessed on July 3, 2012, at http://www.hsia.org/uses.asp.

Hasegawa, R., Takayama, S., and Ito, N., 1994, Effects of low level exposure to multiple carcinogens in combination, in Yang, R.S.H., ed., Toxicology of chemical mixtures: San Diego, Calif., Academic Press, p. 361-382.

Helsel, D.R., and Hirsch, R.M., 2002, Statistical methods in water resources: U.S. Geological Survey Techniques of Water-Resources Investigations, book 4, Hydrologic analysis and interpretation, chapter A3, $510 \mathrm{p}$. Available at $h t t p: / /$ pubs.usgs.gov/twri/twri4a3/pdf/twri4a3-new.pdf.

Hertzberg, R.C., and MacDonell, M.M., 2002, Synergy and other ineffective mixture risk definitions: Science of the Total Environment, v. 288, no. 1-2, p. 31-42. (Also available at http://dx.doi.org/10.1016/S0048-9697(01)01113-5.)

Hladik, M.L., Hsiao, J.J., and Roberts, A.L., 2005, Are neutral chloroacetamide herbicide degradates of potential environmental concern? Analysis and occurrence in the upper Chesapeake Bay: Environmental Science and Technology, v. 39, no. 17, p. 6,561-6,574. (Also available at $h t t p: / / d x$.doi. org/10.1021/es050268w.)
Homer, Collin; Huang, Chengquan; Yang, Limin; Wylie, Bruce; and Coan, Michael, 2007, Development of a 2001 National Land Cover Database for the United States: Photogrammetric Engineering and Remote Sensing, v. 70, no. 7, p. 829-840. (Also available at $h t t p: / / w w w . m r l c . g o v / p d f /$ July_PERS.pdf.)

Hopple, J.A., Delzer, G.C., and Kingsbury, J.A., 2009, Anthropogenic organic compounds in source water of selected community water systems that use groundwater, 2002-05: U.S. Geological Survey Scientific Investigations Report 2009-5200, 74 p. (Also available at http://pubs.usgs.gov/ sir/2009/5200/.)

Ivahnenko, Tamara, and Zogorski, J.S., 2006, Sources and occurrence of chloroform and other trihalomethanes in drinking-water supply wells in the United States, 19862001: U.S. Geological Survey Scientific Investigations Report 2006-5015, 13 p. (Also available at $h t t p: / / p u b s . u s g s$. gov/sir/2006/5015/.)

Ivahnenko, Tamara, and Barbash, J.E., 2004, Chloroform in the hydrologic system - Sources, transport, fate, occurrence, and effects on human health and aquatic organisms: U.S. Geological Survey Scientific Investigations Report 2004-5137, 34 p. (Also available at http://pubs.usgs.gov/ sir/2004/5137/.)

Kalkhoff, S.J., Kolpin, D.W., Thurman, E.M., Ferrer, I., and Barcelo, D., 1998, Degradation of chloroacetanilide herbicides: the prevalence of sulfonic and oxanilic acid metabolites in Iowa groundwaters and surface waters: Environmental Science and Technology, v. 32, no. 11, p. 1,738-1,740. (Also available at $h t t p: / / d x . d o i . o r g / 10.1021 / e s 971138 t$.)

Kingsbury, J.A., Delzer, G.C., and Hopple, J.A., 2008, Anthropogenic organic compounds in source water of nine community water systems that withdraw from streams, 2002-05: U.S. Geological Survey Scientific Investigations Report 2008-5208, 66 p. (Also available at http://pubs.usgs. gov/sir/2008/5208/.)

Klecka, G.M., Gonsior, S.J., and Markham, D.A., 1990, Biological transformations of 1,1,1-trichloroethane in subsurface soils and groundwater: Environmental Toxicology and Chemistry, v. 9, no. 12, p. 1,437-1,451. (Also available at http://dx.doi.org/10.1002/etc.5620091203.)

Kolpin, D.W., Furlong, E.T., Meyer, M.T., Thurman, E.M., Zaugg, S.D., Barber, L.B., and Buxton, H.T., 2002, Pharmaceuticals, hormones, and other organic wastewater contaminants in U.S. streams, 1999-2000-A national reconnaissance: Environmental Science and Technology, v. 36, no. 6, p. 1,202-1,211. (Also available at http://dx.doi.org/10.1021/ es011055j.) 
Lee, E.A., and Strahan, A.P., 2003, Methods of analysis by the U.S. Geological Survey Organic Geochemistry Research Group-Determination of acetamide herbicides and their degradation products in water using online solid-phase extraction and liquid chromatography/mass spectrometry: U.S. Geological Survey Open-File Report 03-173, 17 p., accessed May 20, 2013, at http://pubs.er.usgs.gov/ publication/ofro3173.

Lindley, C.E., Stewart, J.T., and Sandstrom, M.W., 1996, Determination of low concentrations of acetochlor in water by automated solid-phase extraction and gas chromatography with mass-selective detection: Journal of Association of Official Analytical Chemists International, v. 79, no. 4, p. 962-966.

Lorah, M.M., and Olsen, L.D., 1999, Natural attenuation of chlorinated volatile organic compounds in a freshwater tidal wetland-Field evidence of anaerobic biodegradation: Water Resources Research, v. 35, no. 12 , p. 3,811-3,828. (Also available at $h t t p: / / d x$.doi. org/10.1029/1999WR900116.)

Lucius, J.E., Olhoeft, G.R., Hill, P.L., and Duke, S.K., 1992, Properties and hazards of 108 selected substances (1992 ed.): U.S. Geological Survey Open-File Report 92-527, p. 191-195.

Madsen, J.E., Sandstrom, M.W., and Zaugg, S.D., 2003, Methods of analysis by the U.S. Geological Survey National Water Quality Laboratory-A method supplement for the determination of fipronil and degradates in water by gas chromatography/mass spectrometry: U.S. Geological Survey Open-File Report 02-462, 11 p. (Also available at http://pubs.er.usgs.gov/publication/ofr02462.)

Mannsville Chemical Products Corporation, 1999, Chemical products synopsis, chloroform: Adams, N.Y., Mannsville Chemical Products Corporation, 2 p.

Megonigal, J.P., Hines, M.E., and Visscher, P.T., 2004, Anaerobic metabolism - Linkages to trace gases and aerobic processes, in Schlesinger, W.H., ed., Biogeochemistry: Oxford, United Kingdom, Elsevier-Pergamon, p. 317-424.

National Oceanic and Atmospheric Administration, 2008, Air Resources Laboratory: accessed July 30, 2010, at http:// www.arl.noaa.gov/faq/ac4.html.

Olsen, L.D., Valder, J.F., Carter, J.M., and Zogorski, J.S., 2013, Prioritization of constituents for national- and regional-scale ambient monitoring of water and sediment in the United States: U.S. Geological Survey Scientific Investigations Report 2012-5218, 203 p., plus supplemental tables, http://pubs.usgs.gov/sir/2012/5218/.
Pankow, J.F., Rathbun, R.E., and Zogorski, J.S., 1996, Calculated volatilization rates of fuel oxygenate compounds and other gasoline-related compounds from rivers and streams: Chemosphere, v. 33, no. 5, p. 921-937. (Also available at http://dx.doi.org/10.1016/0045-6535(96)00227-5.)

Phillips, P.J., Stinson, B., Zaugg, S.D., Furlong, E.T., Kolpin, D.W., Esposito, K.M., Bodniewicz, B., Pape, R., and Anderson, J., 2005, A multi-disciplinary approach to the removal of emerging contaminants in municipal wastewater treatment plants in New York State, 2003-2004: Water Environment Federation WEFTEC 78th Annual Technical Exhibition and Conference, Proceedings, Washington, D.C., November 2005, p. 5,095-5,124.

Price, C.V., Nakagaki, Naomi, and Hitt, K.J., 2010, National Water-Quality Assessment (NAWQA) Area-Characterization Toolbox, Release 1.0: U.S. Geological Survey OpenFile Report 2010-1268, accessed October 22, 2013, at http://pubs.usgs.gov/of/2010/1268.

Radeloff, V.C., Hammer, R.B., Stewart, S.I., Fried, J.S., Holcomb, S.S., and McKeefry, J.F., 2005, The wildland-urban interface in the United States: Ecological Applications, v. 15, no. 3, p. 799-805. (Also available at $h t t p: / / d x . d o i$. org/10.1890/04-1413.)

Reiter, Lawrence; Falk, Henry; Groat, Charles; and Coussens, C.M., eds., 2004, From source water to drinking waterWorkshop summary: Washington, D.C., The National Academies Press, 108 p.

Rose, D.L., and Sandstrom, M.W., 2003, Methods of analysis by the U.S. Geological Survey National Water Quality Laboratory-Determination of gasoline oxygenates, selected degradates, and BTEX in water by heated purge and trap/ gas chromatography/mass spectrometry: U.S. Geological Survey Water-Resources Investigations Report 03-4079, 31 p. (Also available at http://pubs.er.usgs.gov/publication/ wri034079.)

Rowe, B.L., Toccalino, P.L., Moran, M.J., Zogorski, J.S., and Price, C.V., 2007, Occurrence and potential humanhealth relevance of volatile organic compounds in drinking water from domestic wells in the United States: Environmental Health Perspectives, November, v. 115, no. 11, p. 1,539-1,546. (Also available at $h t t p: / / w w w . j s t o r . o r g /$ stable/4626970.)

Sandstrom, M.W., Stroppel, M.E., Foreman, W.T., and Schroeder, M.P., 2001, Methods of analysis by the U.S. Geological Survey National Water Quality Laboratory-Determination of moderate-use pesticides and selected degradates in water by $\mathrm{C}-18$ solid-phase extraction and gas chromatography/mass spectrometry: U.S. Geological Survey WaterResources Investigations Report 01-4098, 70 p. (Also available at http://pubs.er.usgs.gov/publication/wri20014098.) 
Schroeder, R.A., 2003, Water-quality changes and organiccarbon characterization during recharge with recycled water at a research basin in Montebello Forebay, Los Angeles County, California, 1991-1996: U.S. Geological Survey Water-Resources Investigations Report 03-4146, 260 p. (Also available at http://pubs.usgs.gov/wri/wrir034146/.)

Scorecard, 2006, Chemical profiles: accessed December 22, 2006, at $h t t p: / / w w w . s c o r e c a r d . o r g / c h e m i c a l-p r o f i l e s / i n d e x$. tcl.

Sokal, R.R., and Rohlf, F.J., 1995, Biometry (3d ed.): New York, W.H. Freeman and Company, 887 p.

Spectrum Laboratories Inc., 2010a, Chemical fact sheet: accessed July 30, 2010, at http://www.speclab.com/ compound/c80626.htm.

Spectrum Laboratories Inc., 2010b, Chemical fact sheet, accessed July 30, 2010, at http://www.speclab.com/ compound/c591786.htm.

Squillace, P.J., Scott, J.C., Moran, M.J., Nolan, B.T., and Kolpin, D.W., 2002, VOCs, pesticides, nitrate, and their mixtures in groundwater used for drinking water in the United States: Environmental Science and Technology, v. 36, no. 9, p. 1,923-1,930. (Also available at http://dx.doi.org/10.1021/ es015591n.)

Stackelberg, P.E., Furlong, E.T., Meyer, M.T., Zaugg, S.D., Henderson, A.K., and Reissman, D.B., 2004, Persistence of pharmaceutical compounds and other organic wastewater contaminants in a conventional drinking-water-treatment plant: Science of the Total Environment, v. 329, no. 1-3, p. 99-113. (Also available at $h t t p: / / d x$.doi.org/10.1016/j. scitotenv.2004.03.015.)

Symons, J.M., Bradley L.C., Jr., and Cleveland, T.C., 2000, The drinking water dictionary: Denver, Colo., American Water Works Association, $506 \mathrm{p}$.

Tesoriero, A.J., Loffler, F.E., and Liebscher, Hugh, 2001, Fate and origin of 1,2-dichloropropane in an unconfined shallow aquifer: Environmental Science and Technology, v. 35, no. 3, p. 455-461. (Also available at http://pubs.acs.org/doi/ abs/10.1021/es001289n.)

Thurman, E.M., Goolsby, D.A., Meyer, M.T., Mills, M.S., Pomes, M.L., and Kolpin, D.W., 1992, A reconnaissance study of herbicides and their metabolites in surface water of the Midwestern United States using immunoassay and gas chromatography/mass-spectrometry: Environmental Science and Technology, v. 26, no. 12, p. 2,440-2,447. (Also available at $h t t p: / / d x$.doi.org/10.1021/es00036a016.)
Toccalino, Patricia; Nowell, Lisa; Wilber, William; Zogorski, John; Donohue, Joyce; Eiden, Catherine; Krietzman, Sandra; and Post, Gloria, 2003, Development of Health-Based Screening Levels for use in State- or local-scale water-quality assessments: U.S. Geological Survey Water-Resources Investigations Report 03-4054, 22 p. (Also available at http://pubs.usgs.gov/wri/wri034054/.)

Toccalino, P.L., 2007, Development and application of HealthBased Screening Levels for use in water-quality assessments: U.S. Geological Survey Scientific Investigations Report 2007-5106, 12 p. (Also available at http://pubs.usgs. gov/sir/2007/5106/.)

Toccalino, P.L., and Hopple, J.A., 2010, The quality of our Nation's waters - Quality of water from public-supply wells in the United States, 1993-2007-Overview of major findings: U.S. Geological Survey Circular 1346, 58 p. (Also available from http://pubs.usgs.gov/circ/1346/.)

Toccalino, P.L., Norman, J.E., Booth, N.L., and Zogorski, J.S., 2008, Health-Based Screening Levels-A tool for evaluating what water-quality data may mean to human health: U.S. Geological Survey, National Water-Quality Assessment Program, updated April 10, 2008, accessed January 16, 2009, at http://water.usgs.gov/nawqa/HBSL.

Toccalino, P.L., Norman, J.E., and Hitt, K.J., 2010, Quality of source water from public-supply wells in the United States, 1993-2007: U.S. Geological Survey Scientific Investigations Report 2010-5024, 206 p. (Also available at $h t t p: / /$ pubs.usgs.gov/sir/2010/5024/.)

Toccalino, P.L., Norman, J.E., and Scott, J.C., 2012, Chemical mixtures in untreated water from public-supply wells in the U.S. - Occurrence, composition, and potential toxicity: Science of the Total Environment, v. 431, p. 262-270. (Also available at $h t t p: / / d x$.doi.org/10.1016/j. scitotenv.2012.05.044.)

Toccalino, P.L., Rowe, B.L., and Norman, J.E., 2006, Volatile organic compounds in the Nation's drinking-water supply wells - What findings may mean to human health: U.S. Geological Survey Fact Sheet 2006-3043, 4 p. (Also available at $h t t p: / / p u b s . u s g s . g o v / f s / 2006 / 3043 /$.

United Nations Environmental Programme, 2002, Methyl acrylonitrile: accessed July 30, 2010, at http://www.chem. unep.ch/irptc/sids/OECDSIDS/126987.pdf.

U.S. Department of Agriculture, 2008, Agricultural Research Service (ARS), The ARS pesticide properties database: U.S. Department of Agriculture, accessed June 22, 2009, at http://www.ars.usda.gov/services/docs.htm?docid $=14199$. 
U.S. Department of Health and Human Services, 2011, GRAS Substances (SCOGS) Database, U.S. Food and Drug Administration, accessed May 20, 2013, at $h t t p: / / w w w . f d a$. gov/Food/IngredientsPackagingLabeling/GRAS/SCOGS/ default.htm.

U.S. Environmental Protection Agency, 1980, Sources of toxic compounds in household wastewater: Washington, D.C., Office of Research and Development, EPA 600/2-80-128, $84 \mathrm{p}$.

U.S. Environmental Protection Agency, 1994, Chemical summary for methyl ethyl ketone: Washington, D.C., Office of Pollution Prevention and Toxics, EPA 749-F-94015a: accessed August 28, 2012, at http://www.epa.gov/ chemfact/s_mek.txt.

U.S. Environmental Protection Agency, 1997, Drinking water advisory - Consumer acceptability advice and health effects analysis on mthyl tertiary-butyl ether (MTBE): U.S. Environmental Protection Agency Fact Sheet EPA822-F-97-009, accessed June 20, 2013, at http://water. epa.gov/action/advisories/drinking/upload/2009_04_27_ criteria_drinking_mtbefact.pdf.

U.S. Environmental Protection Agency, 1998, Code of Federal Regulations, title 40-Protection of environment, chapter 1-Environmental Protection Agency, subchapter D-Water programs, part 141-National primary drinking water regulations, 40 CFR 141.24: National Archives and Records Administration, September 19, 1997; amended June 19, 1998, accessed May 20, 2013, at http://www.ecfr.gov/.

U.S. Environmental Protection Agency, 2002, Occurrence summary and use support document for the six-year review of national primary drinking water regulations: Office of Water, EPA-815-D-02-006, 453 p., accessed October 9, 2007, at http://www.epa.gov/safewater/standard/review/ pdfs/support_6yr_occursummaryuse_draft.pdf.

U.S. Environmental Protection Agency, 2003, Water on tap: what you need to know: U.S. Environmental Protection Agency, Office of Water EPA 816-K-03-007, October 2003, 36 p., accessed May 20, 2013, at http://water.epa.gov/ drink/guide/upload/book_waterontap_full.pdf.

U.S. Environmental Protection Agency, 2004, Understanding the safe drinking water act: U.S. Environmental Protection Agency, Office of Water EPA 816-F-04-030, June 2004, 4 p. (Also available at $h t t p: / / w w w . e p a . g o v / o g w d w 000 / s d w a /$ $p d f s / f s \_30 a n n \_s d w a \_w e b . p d f$.)

U.S. Environmental Protection Agency, 2005, Policy to manage access to sensitive drinking water-related information, internal memo, dated April 4, 2005: accessed May 20, 2013, at http://water.epa.gov/infrastructure/watersecurity/ lawsregs/upload/policytomanageaccesstosensitivedwrelated infoApril2005.pdf.
U.S. Environmental Protection Agency, 2006a, 2006 Edition of the drinking water standards and health advisories: Washington, D.C., U.S. Environmental Protection Agency, Office of Water, EPA 822-R-06-013, 12 p., accessed August 2006, http://www.epa.gov/waterscience/criteria/drinking/ dwstandards.pdf.

U.S. Environmental Protection Agency, 2006b, Iodomethane risk assessment; notice of availability: accessed July 30, 2010, at http://www.epa.gov/fedrgstr/EPA-PEST/2006/ January/Day-06/p28.htm.

U.S. Environmental Protection Agency, 2007, Concepts, methods and data sources for cumulative health risk assessment of multiple chemicals, exposures and effects: a resource document (final report): U.S. Environmental Protection Agency, Office of Research and Development, National Center for Environmental Assessment EPA/600/R-06/013F, August 2007, variously paged. (Also available at $h t t p: / /$ cfpub.epa.gov/ncea/cfm/recordisplay.cfm?deid=190187.)

U.S. Environmental Protection Agency, 2008a, Drinking water and the Unregulated Contaminant Monitoring Regulation (UCMR) - A tool to find contaminants: U.S. Environmental Protection Agency, Office of Water, EPA 815-F-08-010, $2 \mathrm{p}$.

U.S. Environmental Protection Agency, 2008b, OverviewMethyl tertiary butyl ether (MTBE): accessed July 25, 2012, at $h t t p: / / w w w . e p a . g o v / m t b e / f a q . h t m$.

U.S. Environmental Protection Agency, 2009a, Drinking water contaminants: U.S. Environmental Protection Agency, Office of Water, updated September 11, 2009, accessed January 29, 2010, at http://www.epa.gov/safewater/ contaminants/basicinformation.html.

U.S. Environmental Protection Agency, 2009b, Water on tap, what you need to know: U.S. Environmental Protection Agency, Office of Water: accessed January 26, 2010, at http://www.epa.gov/ogwdw/wot/pdfs/book_waterontap_full. $p d f$.

U.S. Environmental Protection Agency, 2009c, Inert (other) pesticide ingredients in pesticide products - Categorized list of inert (other) pesticide ingredients, accessed July 29, 2010, at http://www.epa.gov/opprd001/inerts/oldlists.html.

U.S. Environmental Protection Agency, 2010, Public Drinking Water Systems: Facts and Figures: accessed October 29, 2012, at http://water.epa.gov/infrastructure/drinkingwater/ pws/factoids.cfm.

U.S. Environmental Protection Agency, 2012a, CCL and Regulatory Determinations Home: U.S. Environmental Protection Agency, Office of Water, updated May, 09, 2012, accessed November 1, 2013, at http://water.epa.gov/scitech/ drinkingwater/dws/ccl/index.cfm. 
U.S. Environmental Protection Agency, 2012b, Safe Drinking Water Information System: accessed July 20, 2012, at http:// water.epa.gov/scitech/datait/databases/drink/sdwisfed/ index.cfm.

U.S. Environmental Protection Agency, 2012c, 2012 Edition of the Drinking Water Standards and Health Advisories: Washington, D.C., U.S. Environmental Protection Agency, Office of Water, EPA 822-S-12-001, 20 p., accessed October 2013, http://www.epa.gov/waterscience/criteria/ drinking/dwstandards.pdf.

U.S. Environmental Protection Agency, 2012d, Atrazine background: accessed January 7, 2013, at http://www.epa.gov/ opp00001/factsheets/atrazine_background.htm.

U.S. Environmental Protection Agency, 2013a, Drinking water contaminants: accessed November 1, 2013, at http://water. epa.gov/drink/contaminants/index.cfm.

U.S. Environmental Protection Agency, 2013b, Methyl tertiary butyl ether (MTBE) — Gasoline: accessed June 17, 2013, at http://www.epa.gov/mtbe/gas.htm.

U.S. Environmental Protection Agency and U.S. Geological Survey, 2010, NHDPlus Version 1 (NHDPlusV1) User Guide: accessed October 29, 2013, at ftp://ftp.horizonsystems.com/NHDPlus/NHDPlusV1/documentation/ NHDPLUSV1 UserGuide.pdf.

U.S. General Accounting Office, 1997, Drinking water-information on the quality of water found at community water systems and private wells: U.S. General Accounting Office, Resources, Community, and Economic Development Division GAO/RCED-97-123, June 12, 1997, 51 p. (Also available at http://www.gao.gov/archive/1997/rc97123.pdf.)

U.S. Geological Survey, 2007a, Facing tomorrow's challenges-U.S. Geological Survey science in the decade 2007-2017: U.S. Geological Survey Circular 1309, 70 p. (Also available at $h t t p: / / p u b s . u s g s . g o v / c i r c / 2007 / 1309 /$.

U.S. Geological Survey, 2007b, Toxic Substances Hydrology Program-Fuel oxygenates: accessed January 17, 2007, at http://toxics.usgs.gov/definitions/fuel_oxygenates.html.

U.S. Geological Survey, variously dated, National field manual for the collection of water-quality data: U.S. Geological Survey Techniques of Water-Resources Investigations, book 9, chaps. A1-A9, accessed July 29, 2010, at http://pubs. water.usgs.gov/twri9A.

U.S. National Library of Medicine, 2006, TOXNET-Toxicology data network: accessed December 22, 2006, at http:// toxnet.nlm.nih.gov/.
U.S. National Library of Medicine, 2010, Household products database: accessed July 30, 2010, at $h t t p: / /$ householdproducts.nlm.nih.gov/.

U.S. Senate, 2002, Title XIV of the Public Health Service Act - Safety of public water systems (Safe Drinking Water Act); part A-definitions (as amended through P.L. 107377): updated December 31, 2002, accessed November 4, 2009, at http://epw.senate.gov/sdwa.pdf.

Valder, J.F., Delzer, G.C., Bender, D.A., and Price, C.V., 2011, Percent recoveries of anthropogenic organic compounds with and without the addition of ascorbic acid to preserve finished-water samples containing free chlorine, 2004-10: U.S. Geological Survey Open-File Report 2011-1295, 65 p., accessed May 20, 2013, at http://pubs.usgs.gov/ of/2011/1295/.

Vogel, T.M., and McCarty, P.L., 1985, Biotransformation of tetrachloroethylene to trichloroethylene, dichloroethylene, vinyl chloride, and carbon dioxide under methanogenic conditions: Applied and Environmental Microbiology, v. 49, no. 5, p. 1,080-1,083.

Westrick, J.J., 1990, National surveys of volatile organic compounds in ground and surface waters, in Ram, N.M., Christman, R.F., and Cantor, K.P., eds., Significance and treatment of volatile organic compounds in water supplies: Chelsea, Mich., Lewis Publishers, p. 103-125.

Westrick, J.J., Mello, J.W., and Thomas, R.F., 1984, The groundwater supply survey: Journal of American Water Works Association, v. 76, no. 5, p. 52-59.

Wiedemeier, T.H., Swanson, M.A., Wilson, J.T., Kampbell, D.H., Miller, R.H., and Hansen, J.E., 1996, Approximation of biodegradation rate constants for monoaromatic hydrocarbons (BTEX) in groundwater: Groundwater Monitoring and Remediation, v.16, no. 3, p. 186-194. (Also available at http://dx.doi.org/10.1111/j.1745-6592.1996.tb00149.x.)

Wolock, D.M., 2003, Estimated mean annual natural groundwater recharge estimates in the conterminous United States: U.S. Geological Survey Open-File Report 03-311, digital data set, Data accessed April 7, 2012, at http://water.usgs. gov/lookup/getspatial?rech48grd.

Wood, Alan, 2010, Compendium of pesticide common names, accessed July 29, 2010, at $h t t p: / / w w w . a l a n w o o d . n e t /$ pesticides/index.html.

Yang, R.S.H., 1994, Introduction to the toxicology of chemical mixtures, in Yang, R.S.H., ed., Toxicology of chemical mixtures: San Diego, Calif., Academic Press, p. 1-10. 
Zaugg, S.D., Sandstrom, M.W., Smith, S.G., and Fehlberg, K.M., 1995, Methods of analysis by the U.S. Geological Survey National Water Quality Laboratory-Determination of pesticides in water by $\mathrm{C}-18$ solid-phase extraction and capillary-column gas chromatography/mass spectrometry with selected-ion monitoring: U.S. Geological Survey Open-File Report 95-181, 49 p., accessed May 20, 2013, at http://nwql.usgs.gov/Public/pubs/OFR95-181/OFR95-181. html.

Zaugg, S.D., Smith, S.G., Schroeder, M.P., Barber, L.B., and Burkhardt, M.R., 2002, Methods of analysis by the U.S. Geological Survey National Water Quality LaboratoryDetermination of wastewater compounds by polystyrenedivinylbenzene solid-phase extraction and capillarycolumn gas chromatography/mass spectrometry: U.S. Geological Survey Water-Resources Investigations Report 01-4186, 37 p. (Also available at http://pubs.usgs.gov/wri/ wri014186/.)
Zogorski, J.S., Carter, J.M., Ivahnenko, Tamara, Lapham, W.W., Moran, M.J., Rowe, B.L., Squillace, P.J., and Toccalino, P.L., 2006, The quality of our Nation's watersVolatile organic compounds in the Nation's ground water and drinking-water supply wells: U.S. Geological Survey Circular 1292, 101 p. (Also available at http://pubs.usgs. gov/circ/circ1292/.) 


\begin{abstract}
Appendix 1. Compounds Monitored, Chemical Abstract Service Registry Number (CASRN), Drinking-Water Benchmark, Primary Use or Source Group, and Analytical Schedule
\end{abstract}




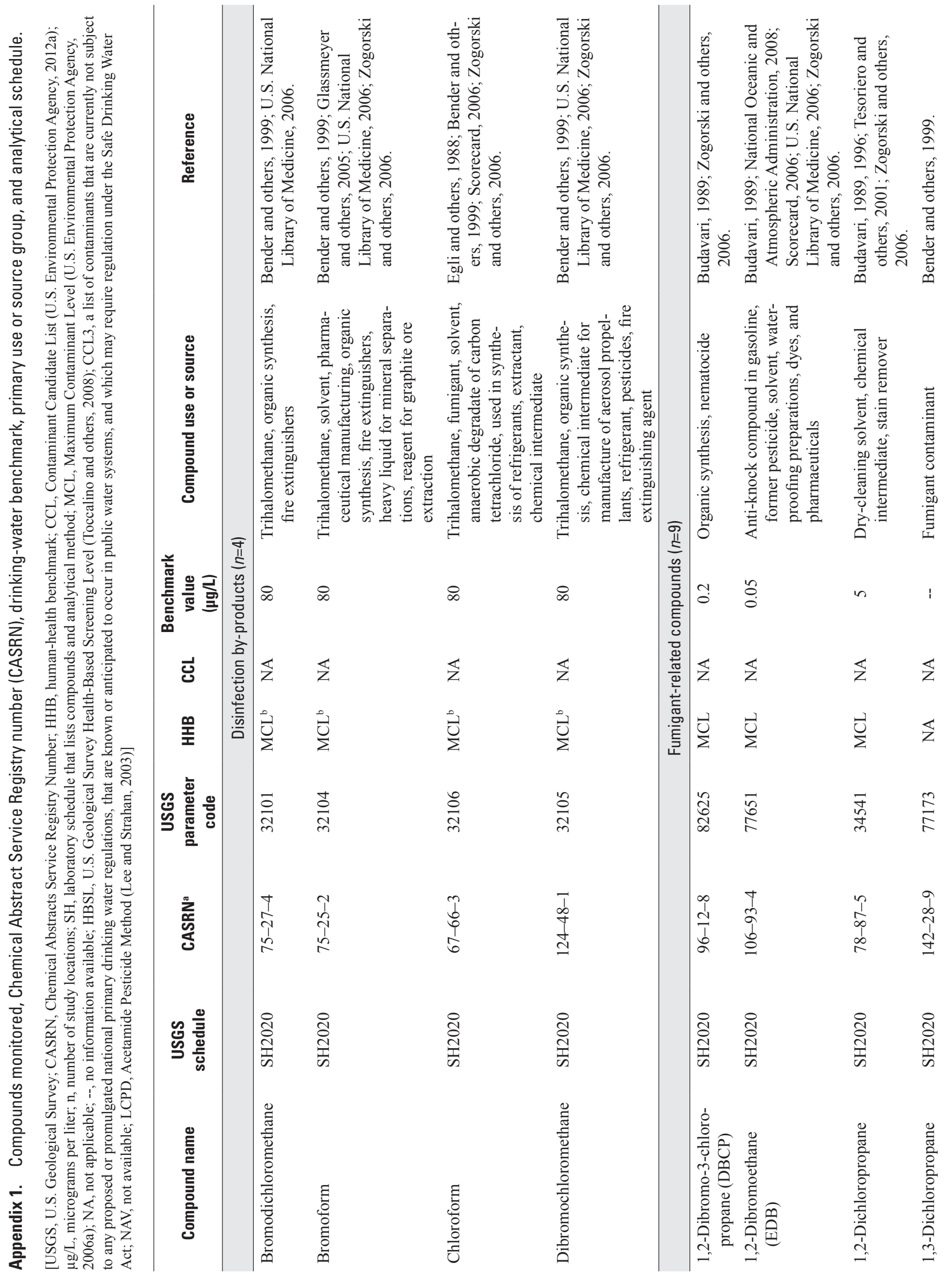




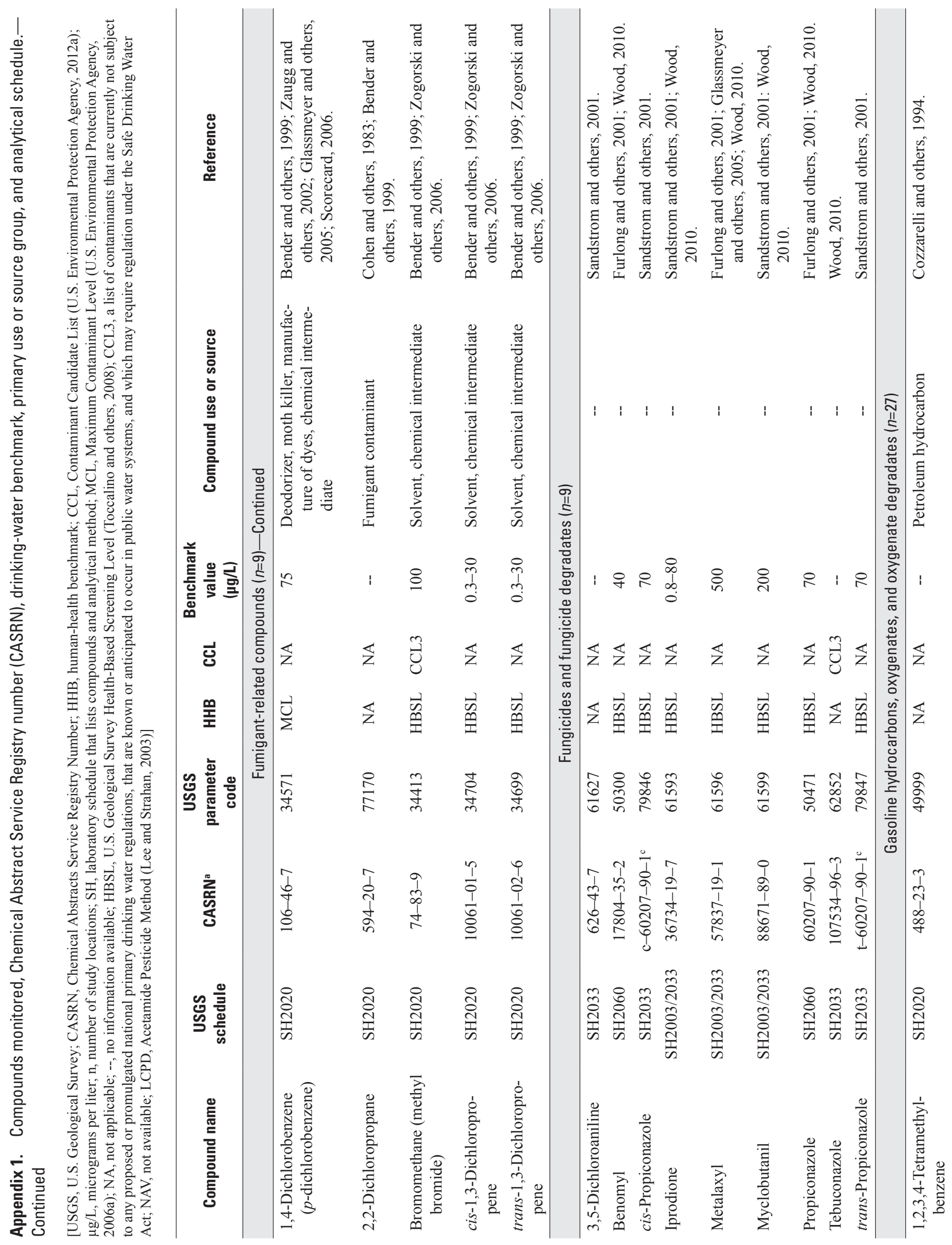




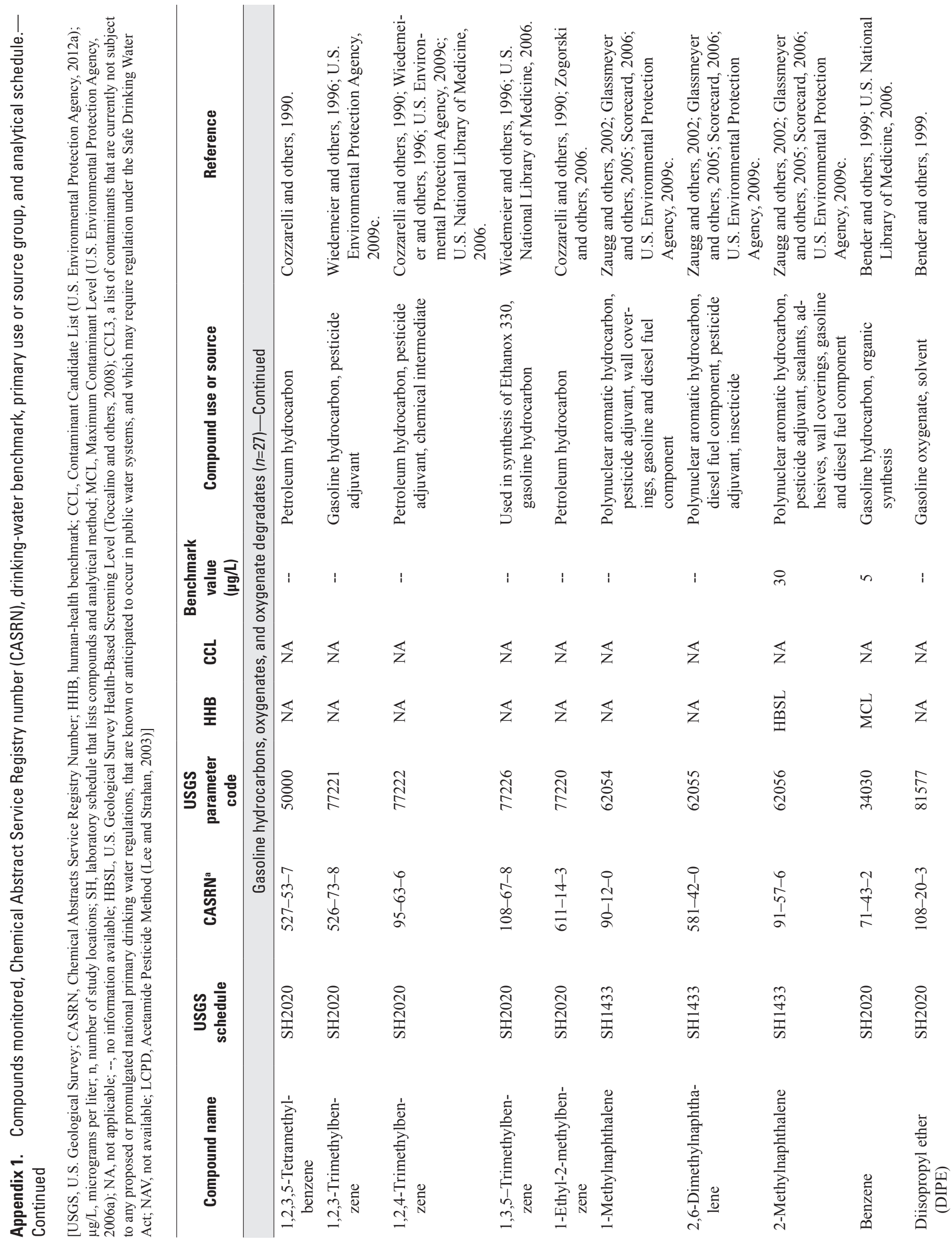




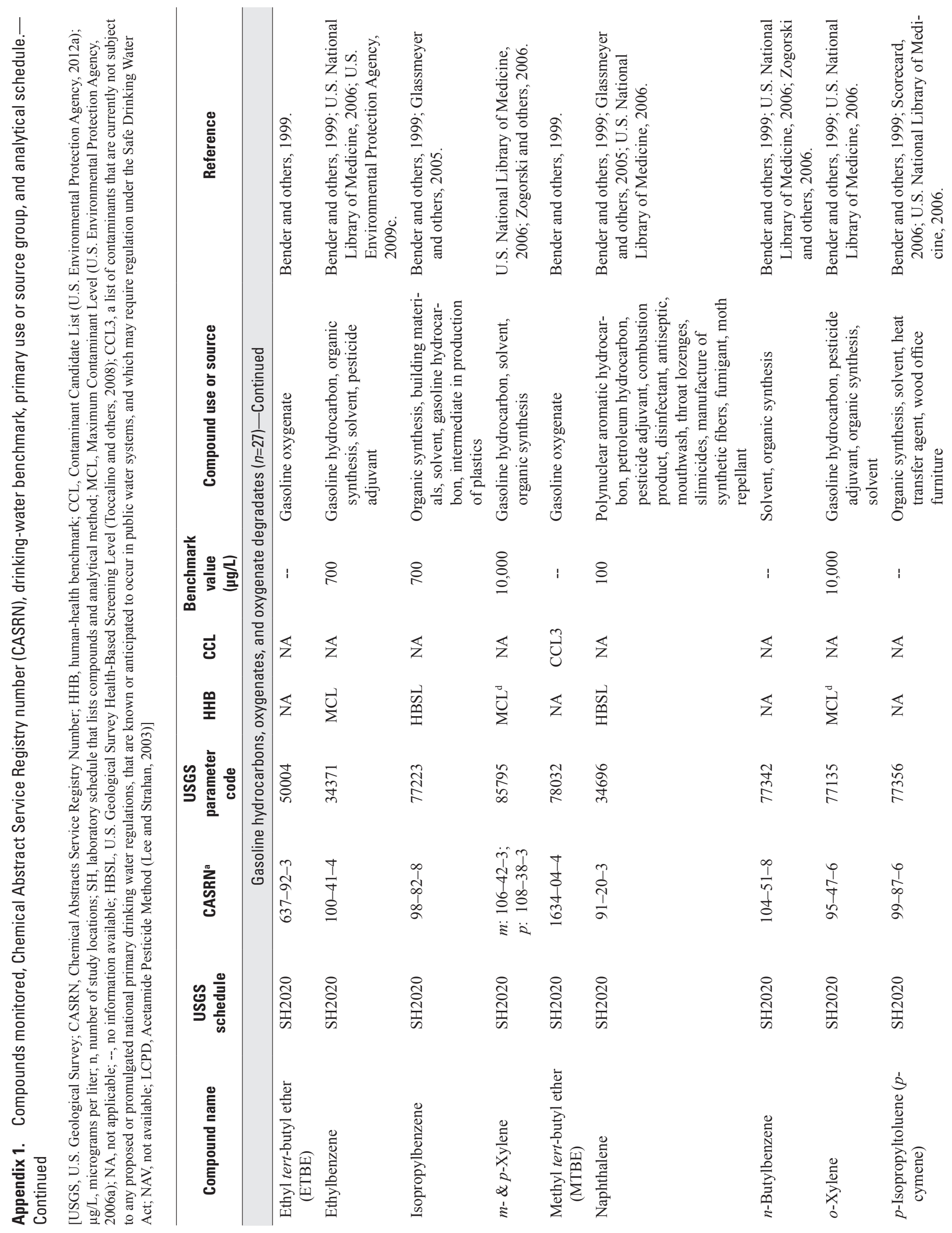




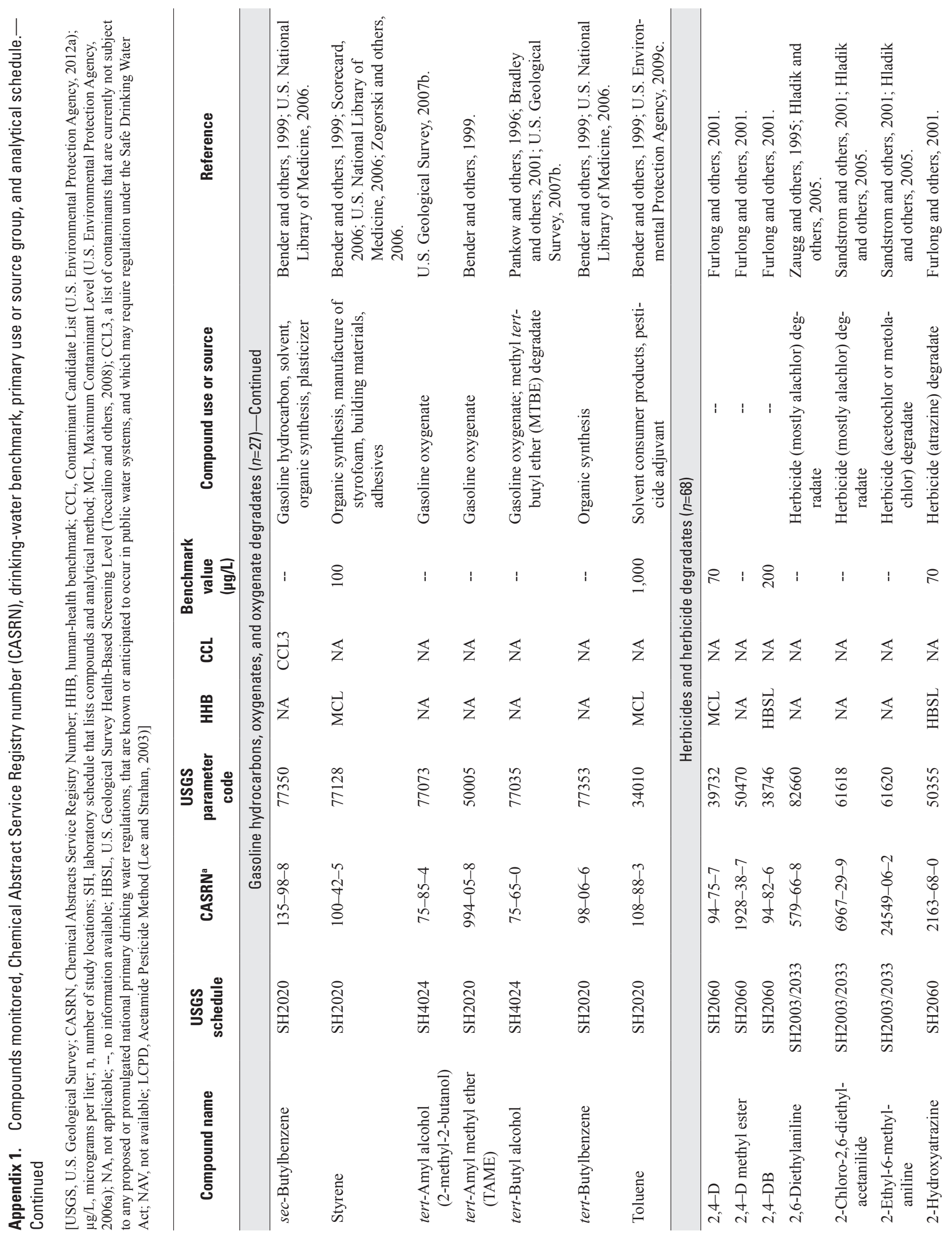




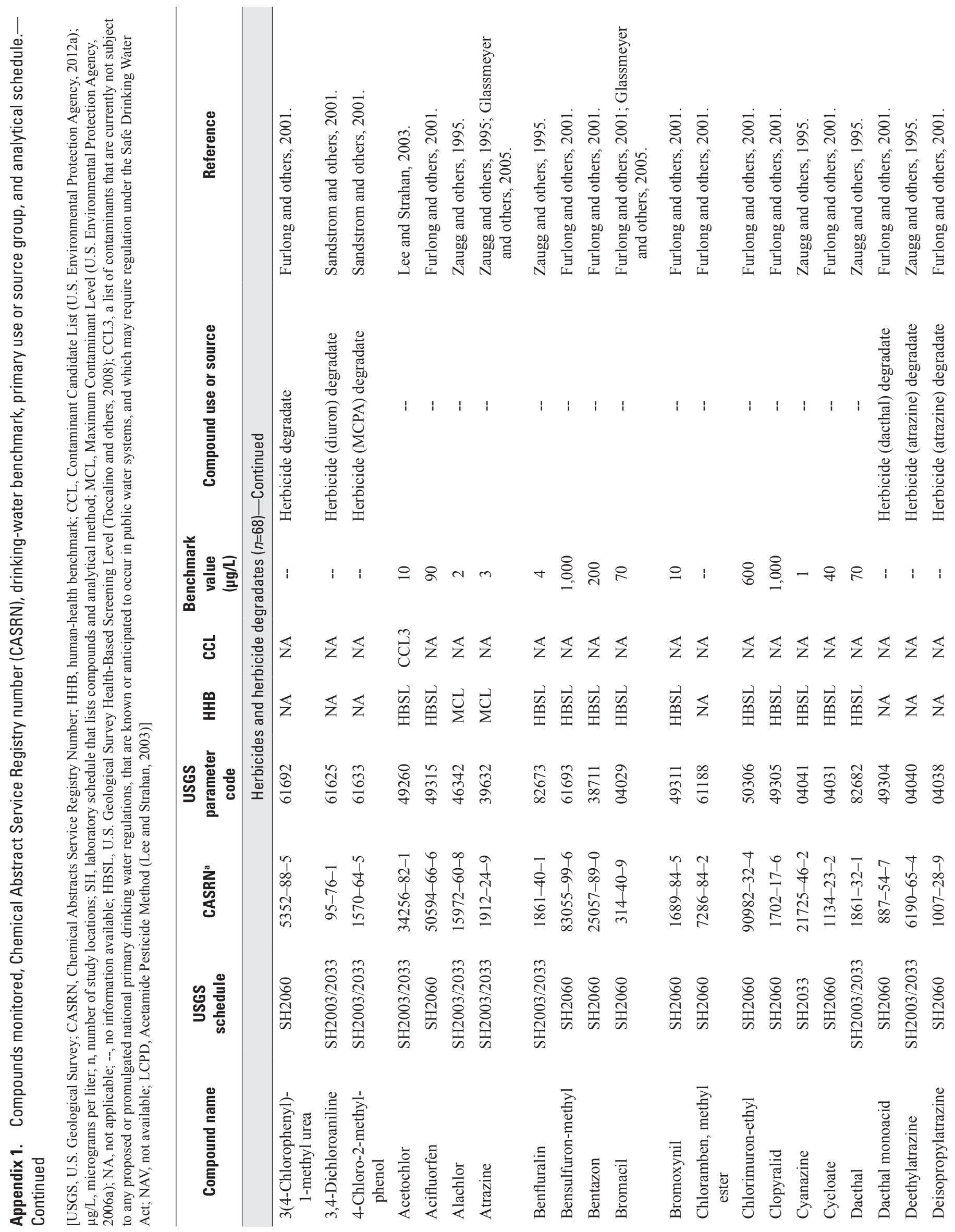




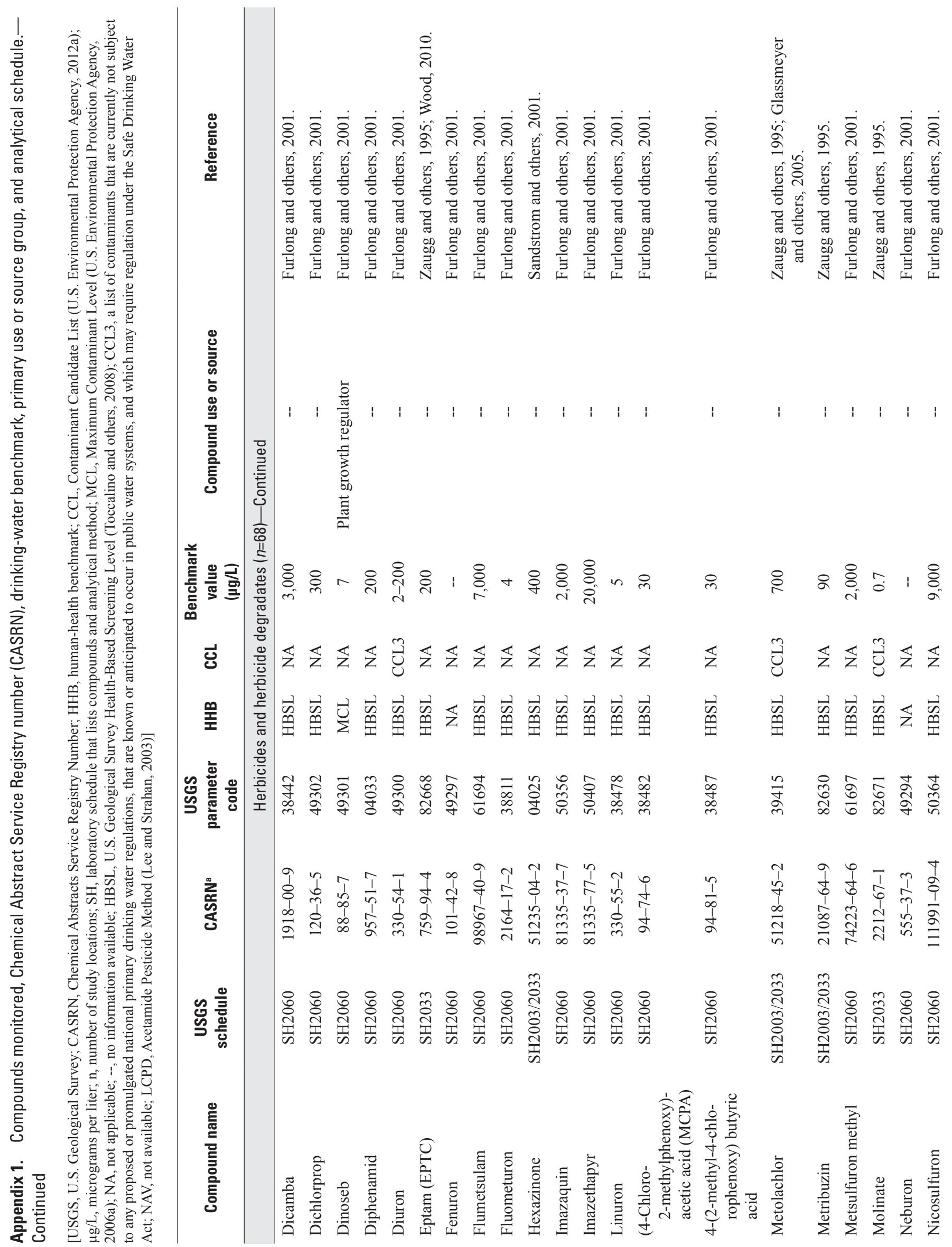




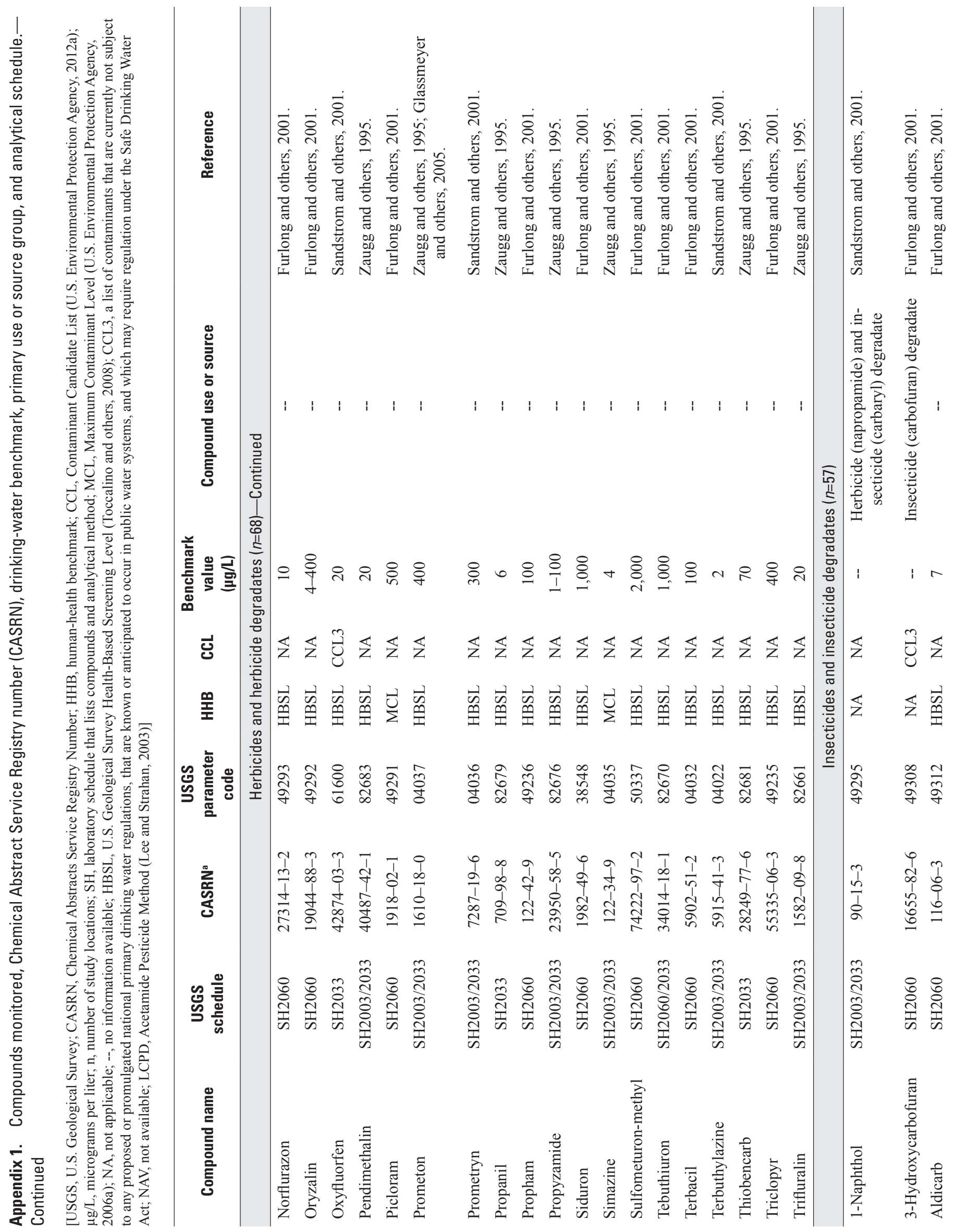




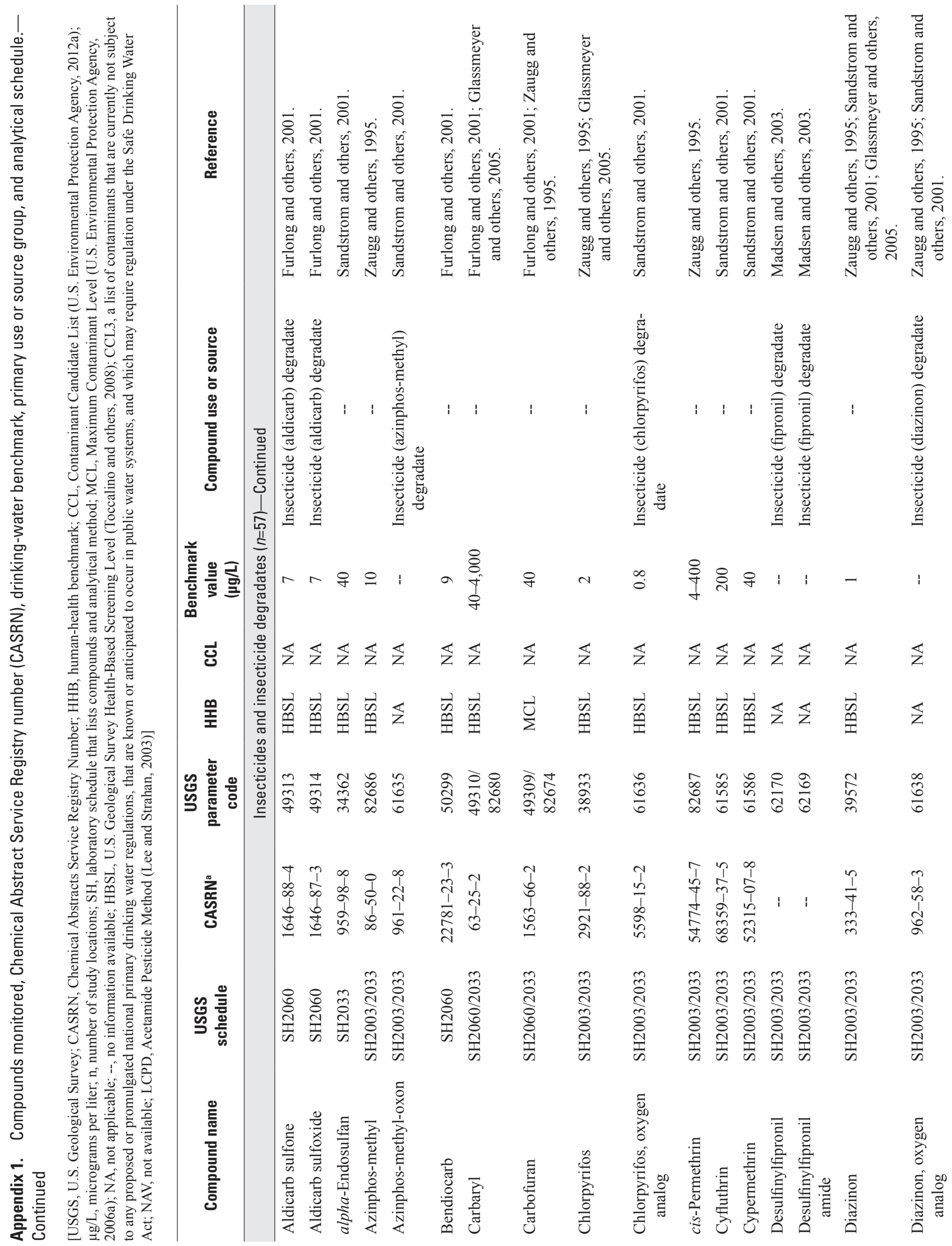




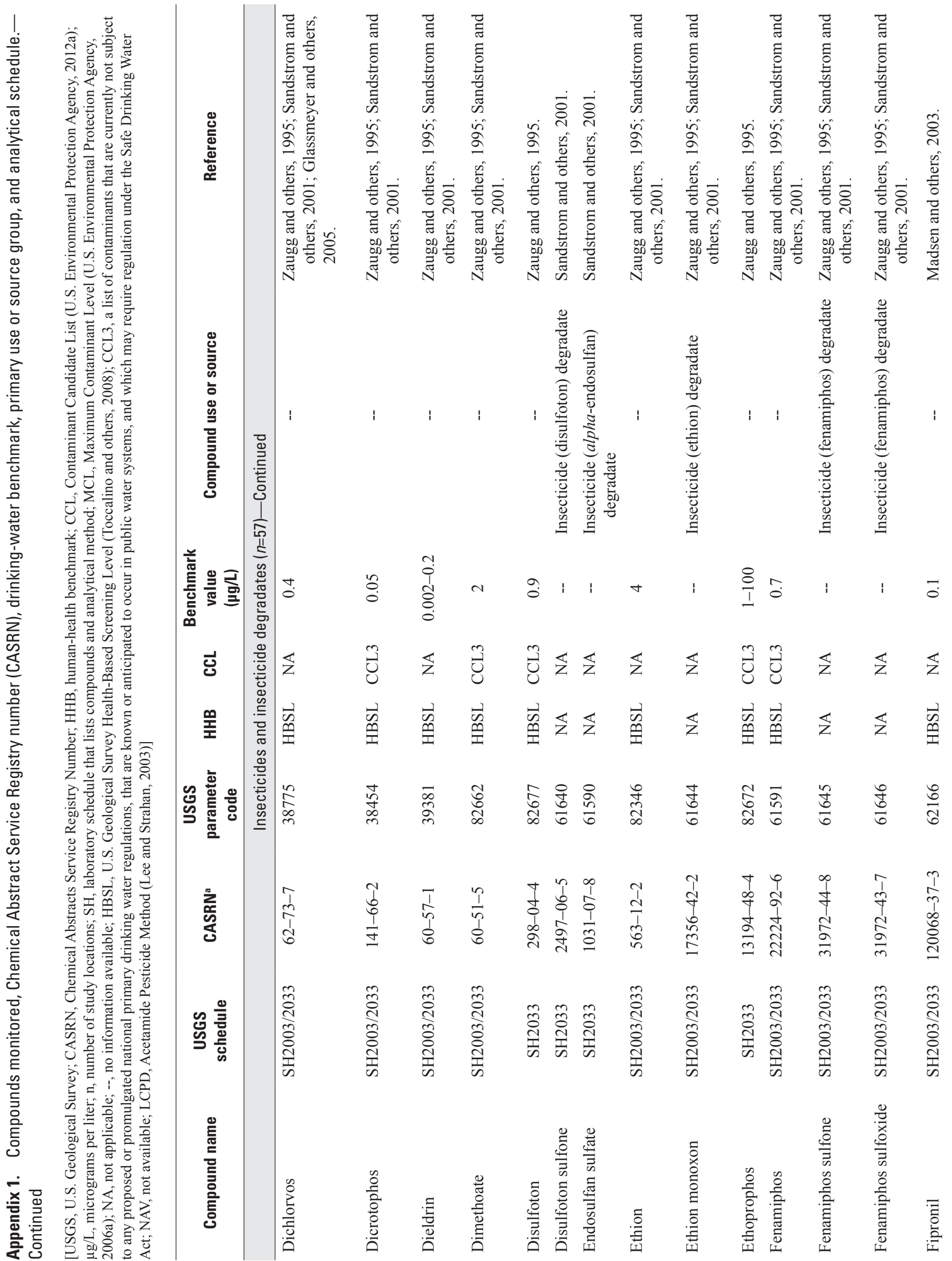




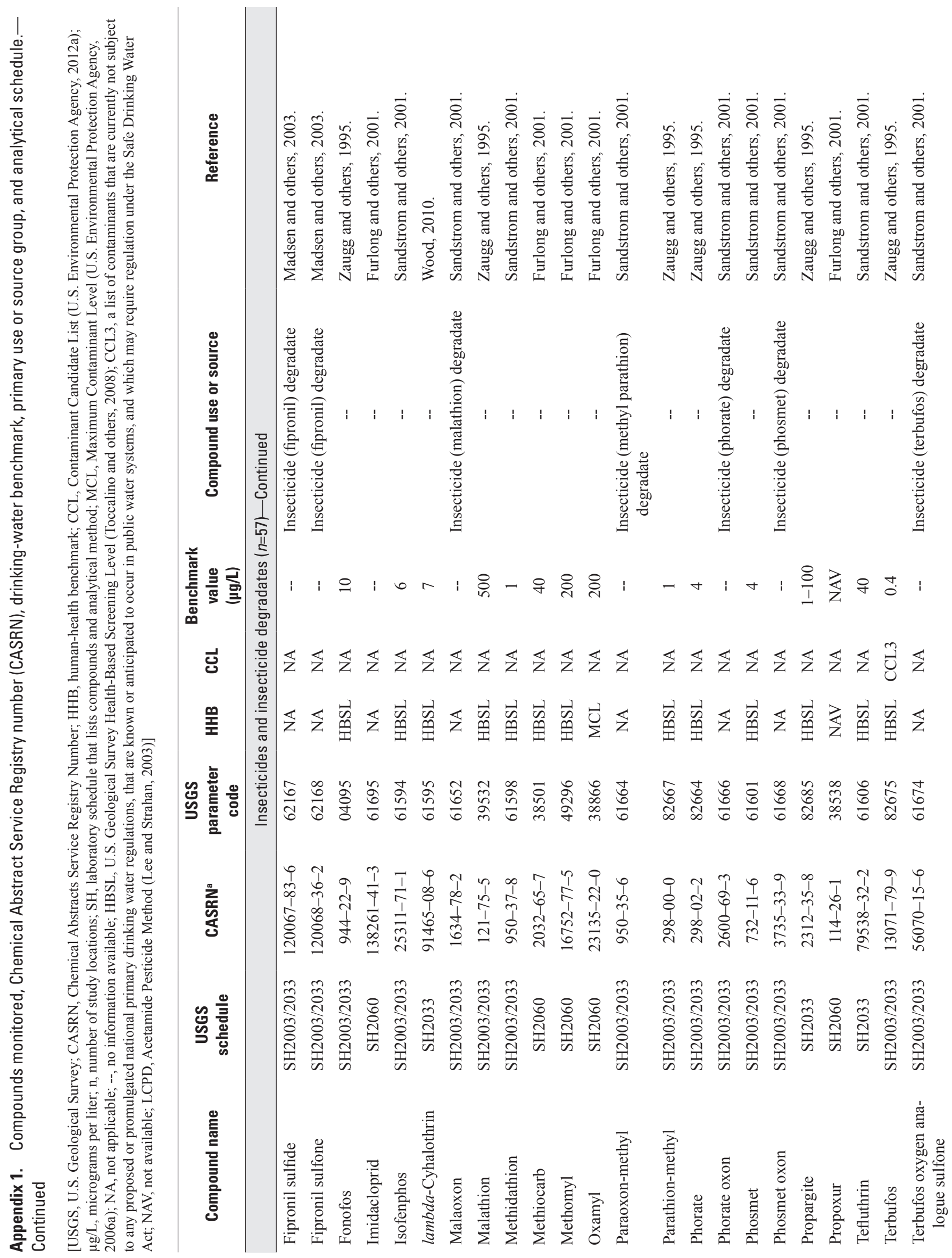




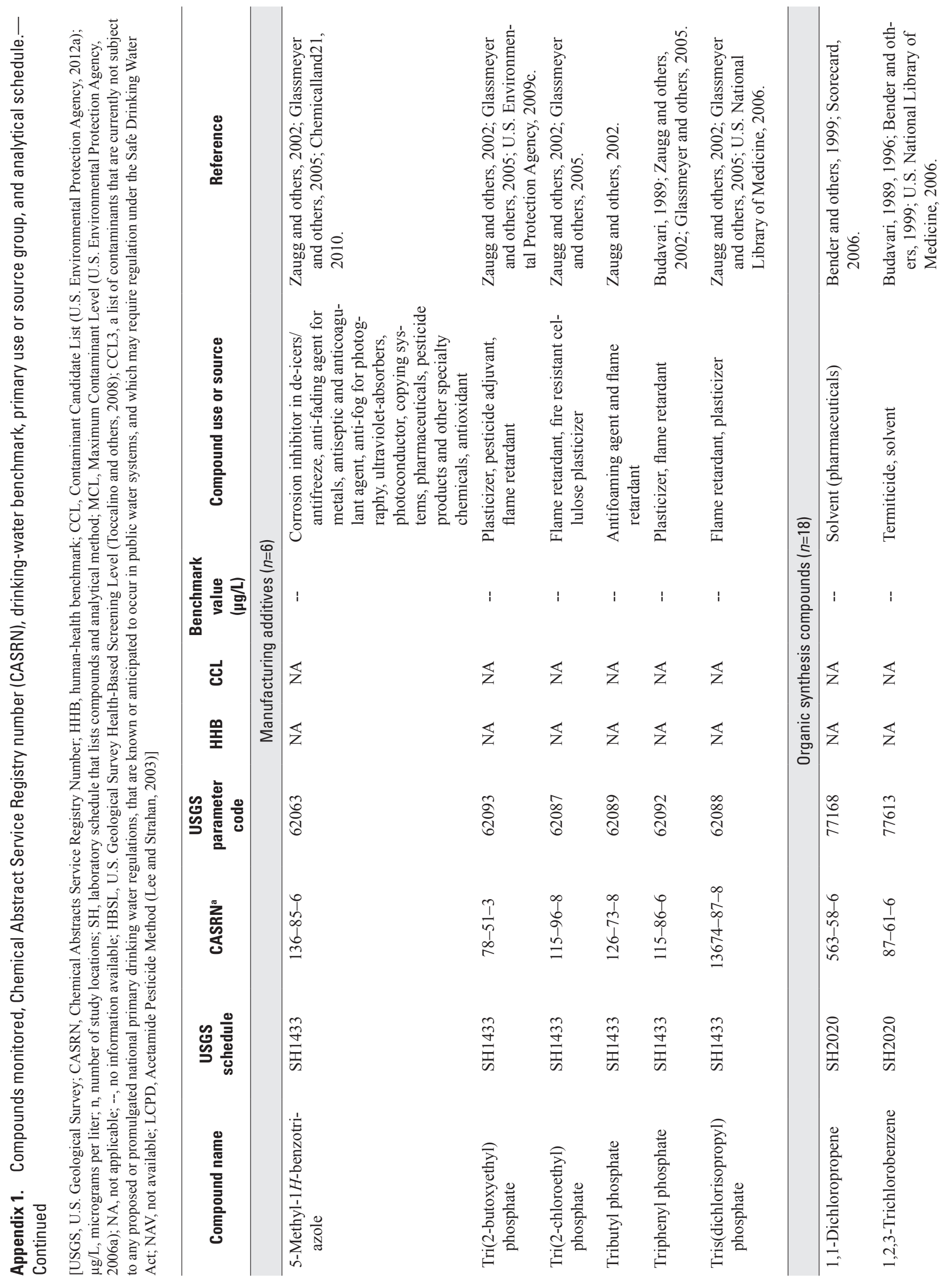




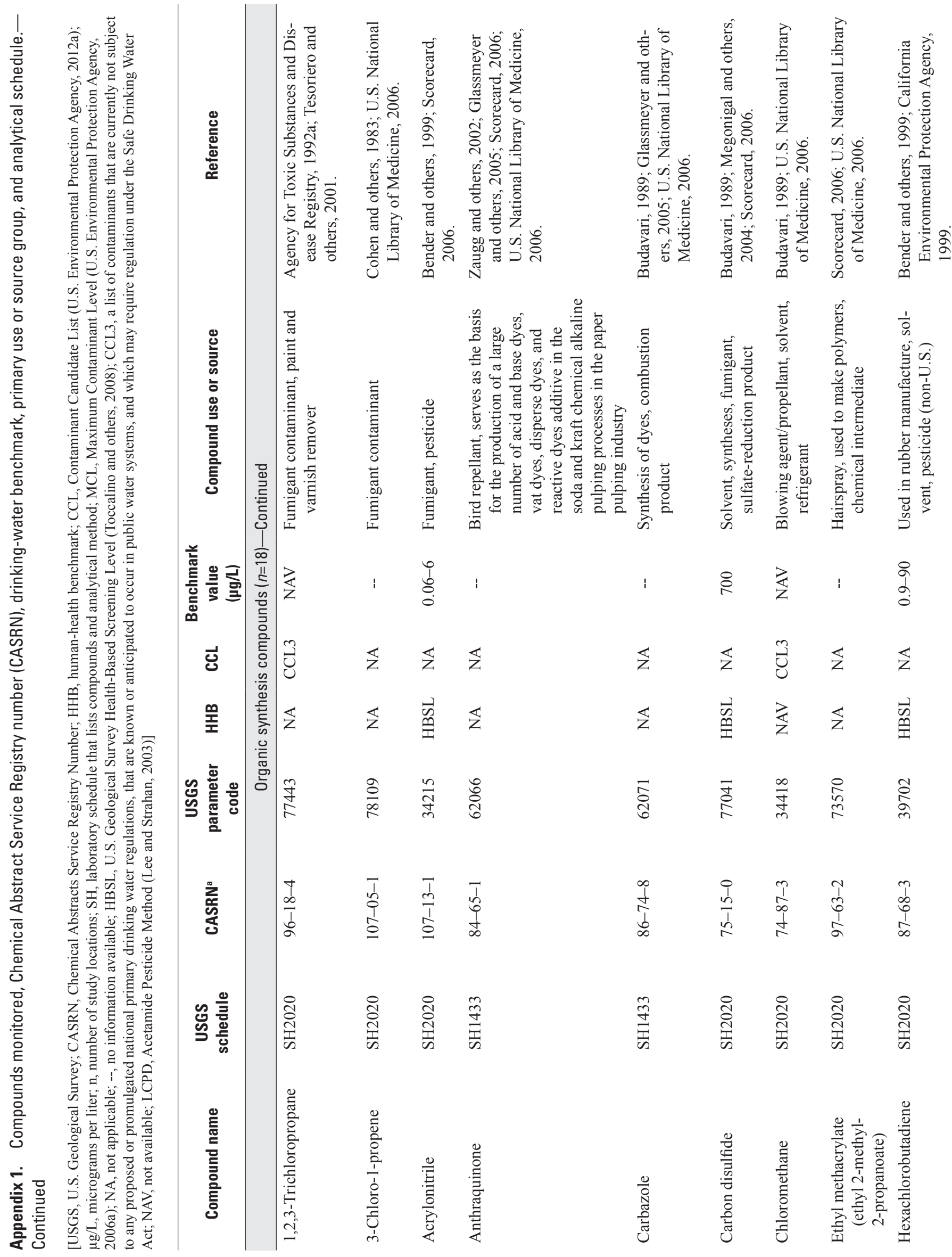




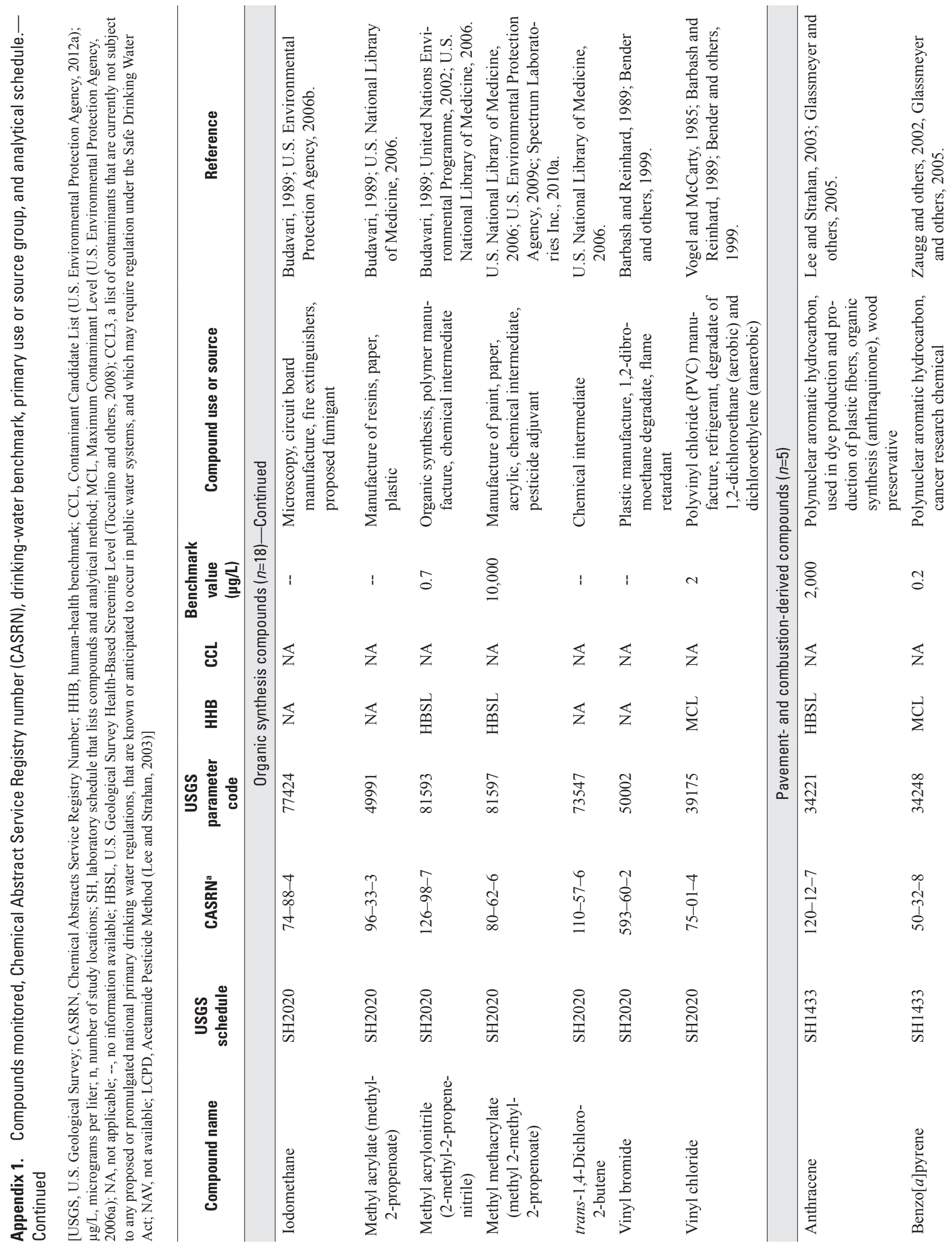




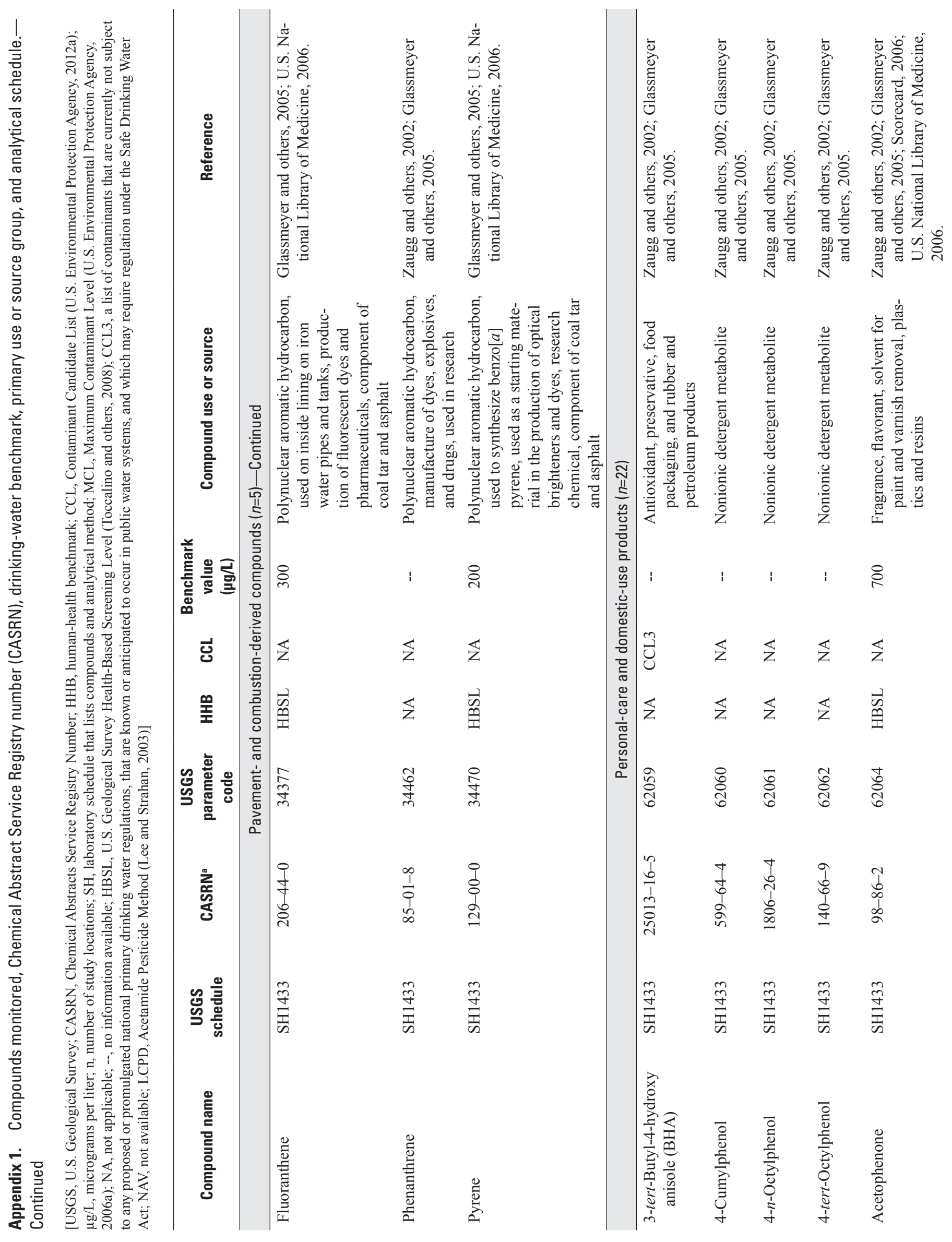




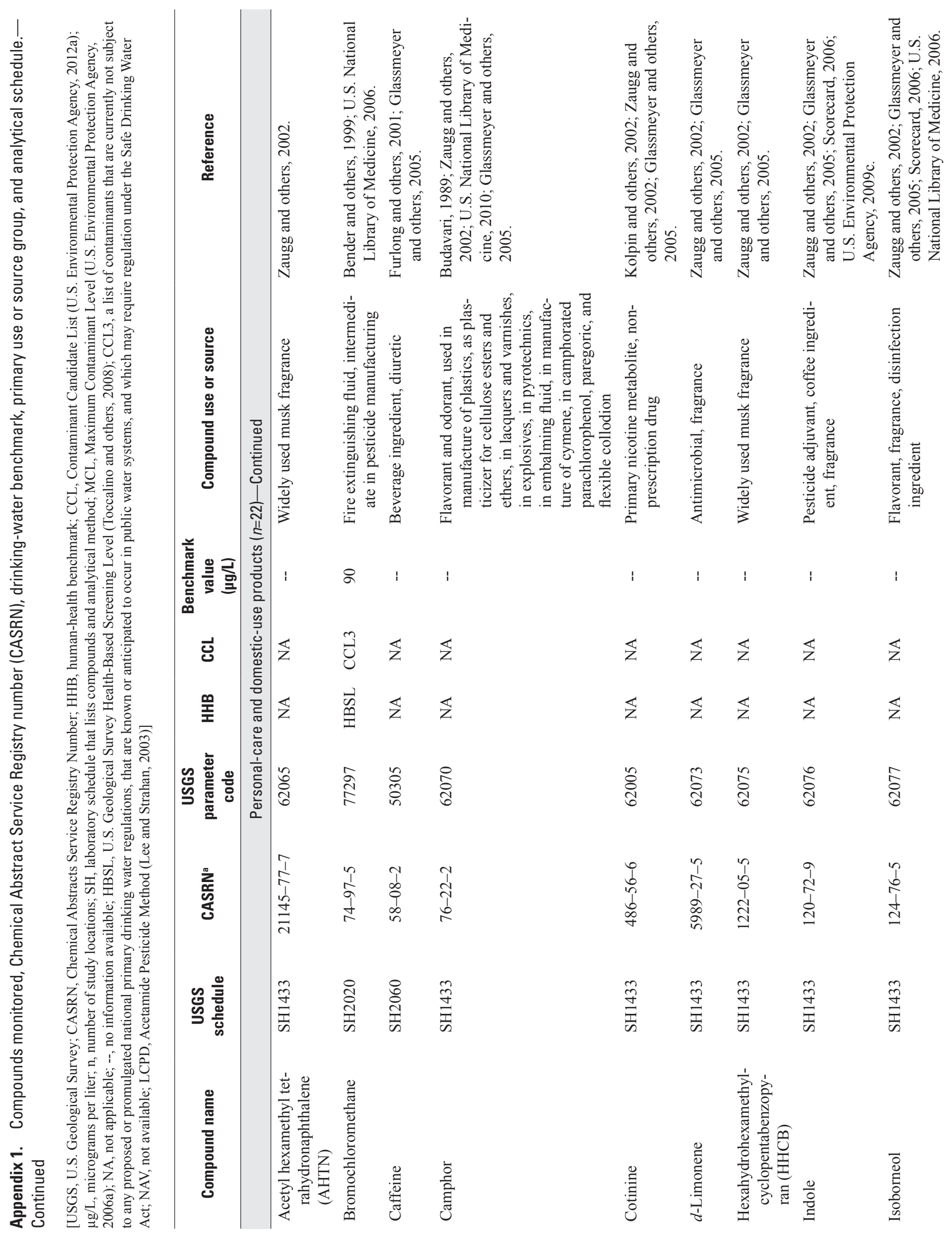




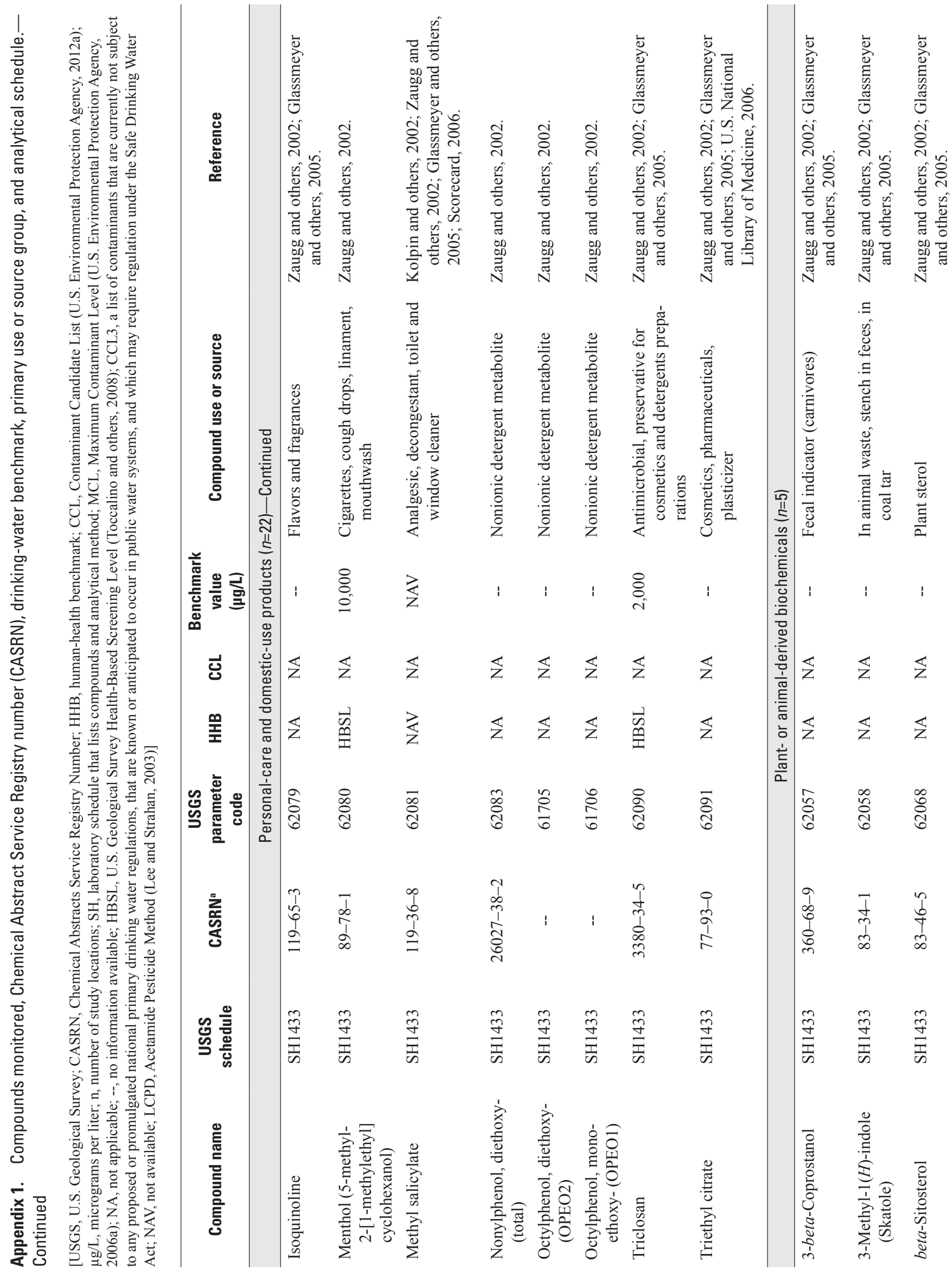




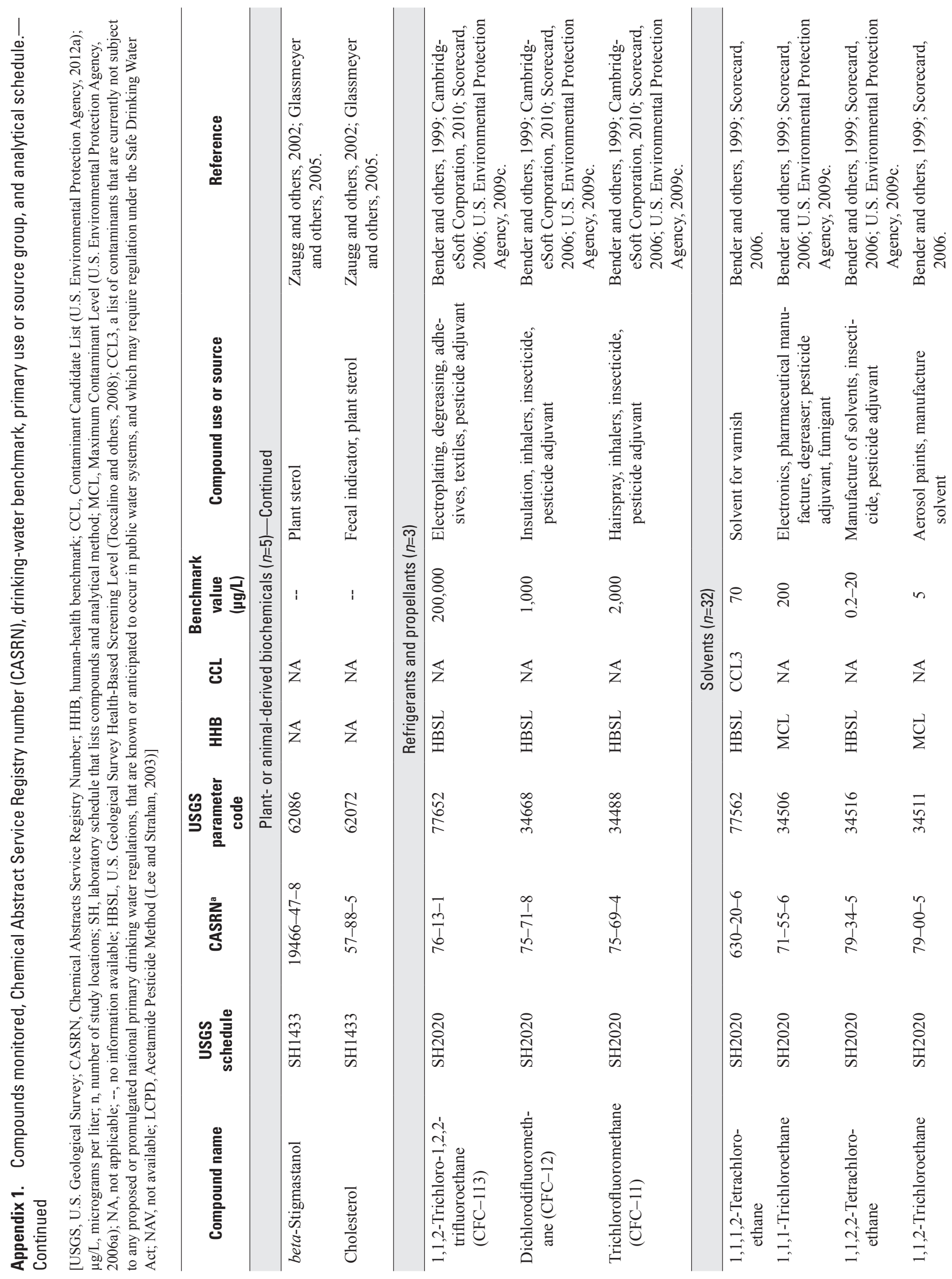




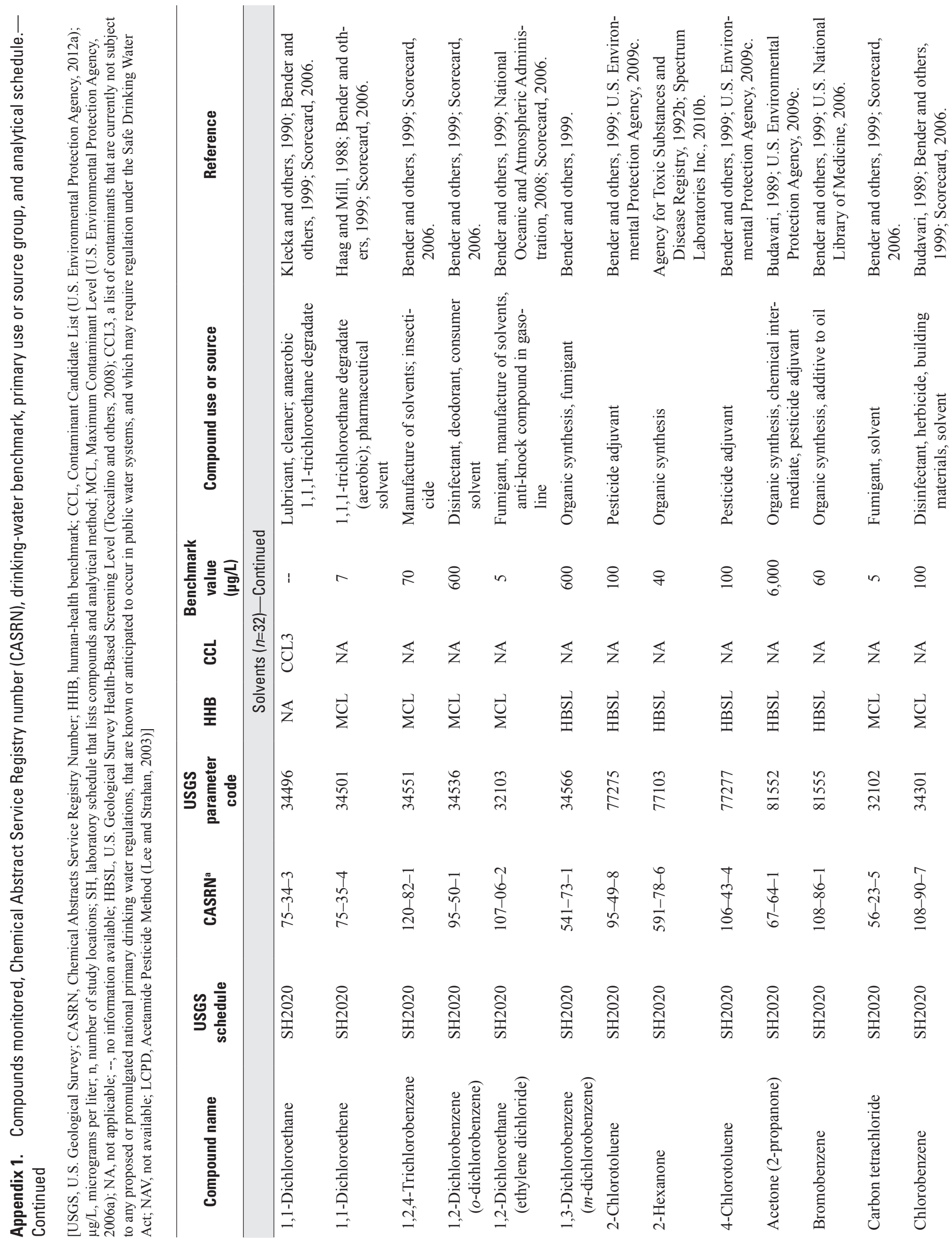




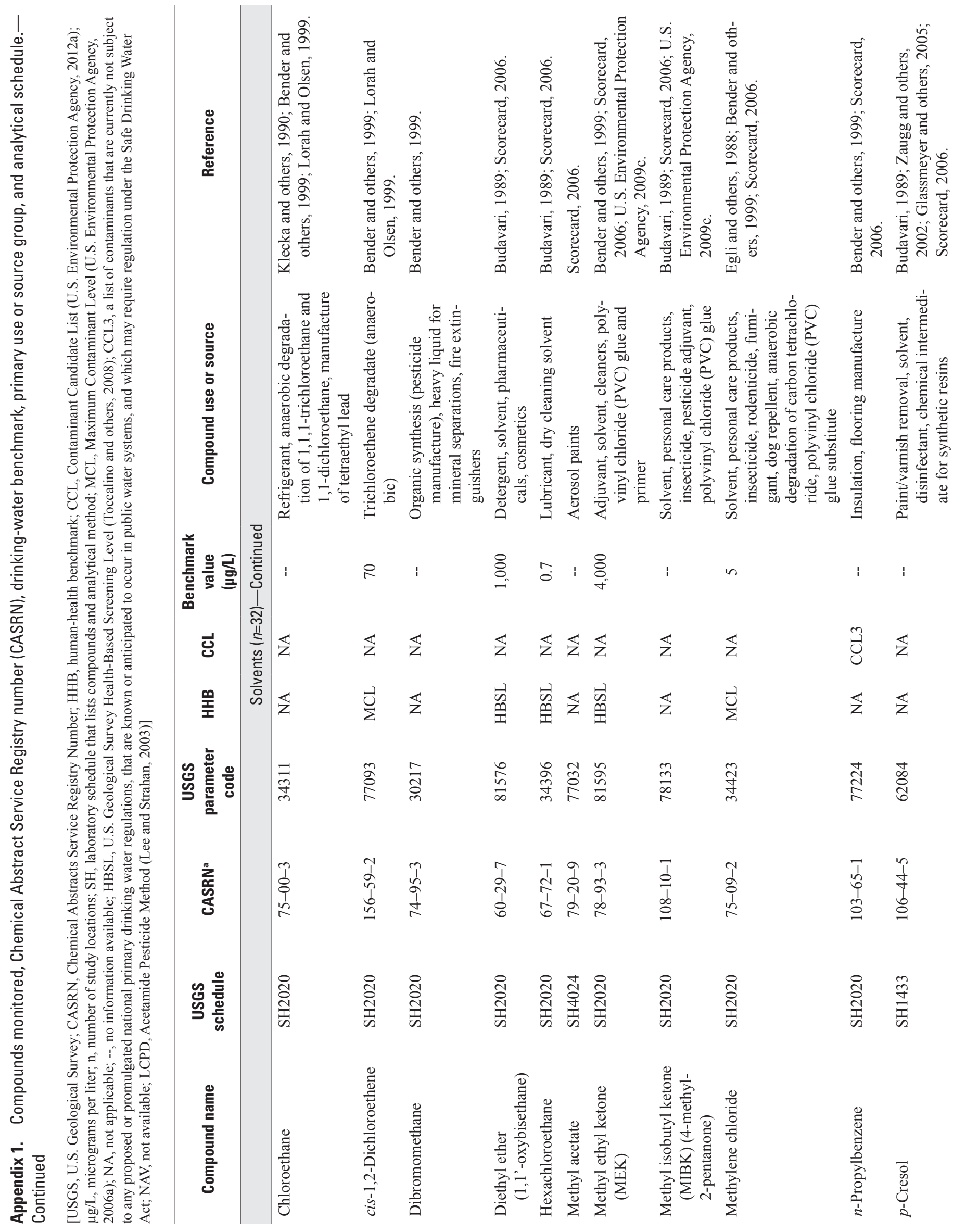




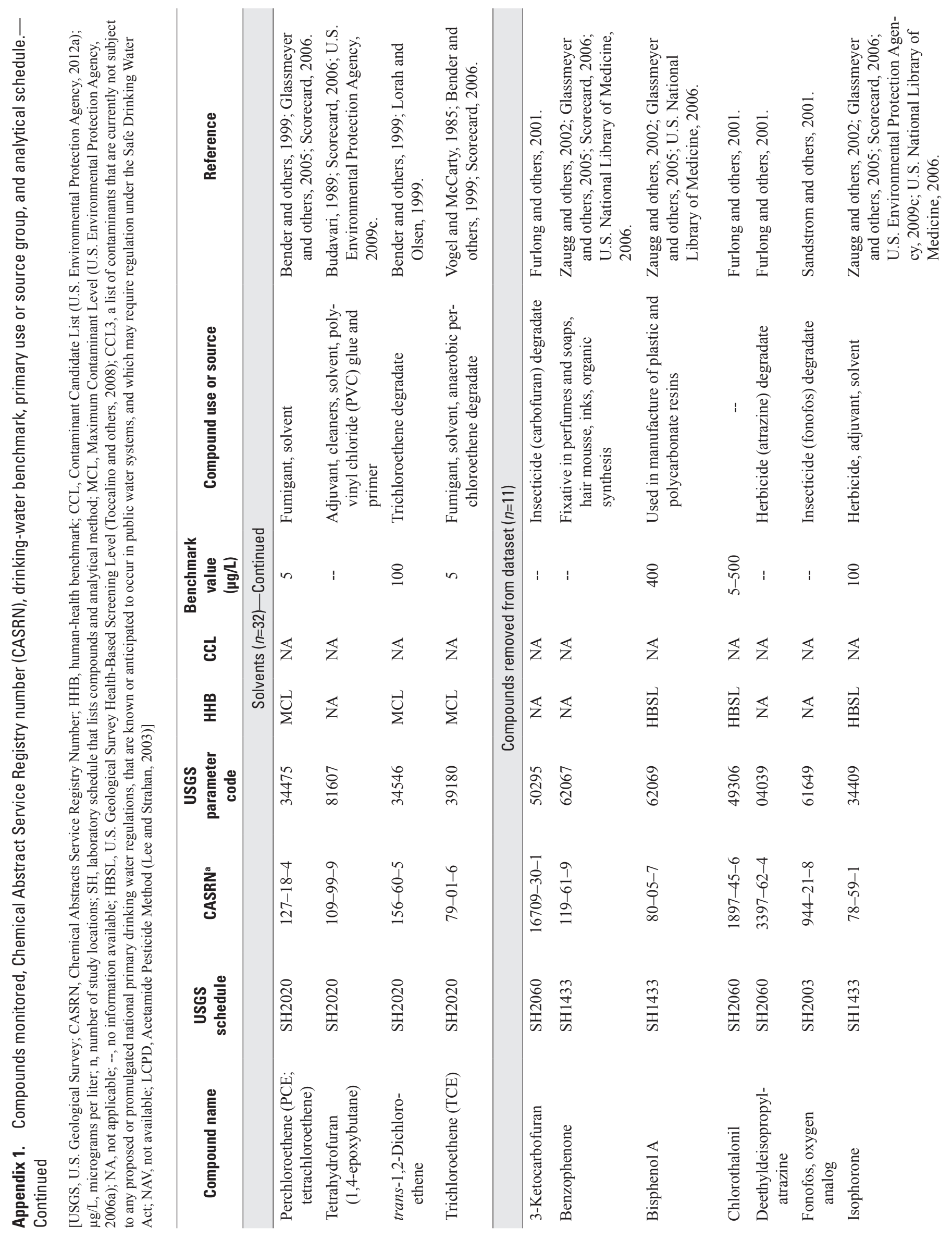




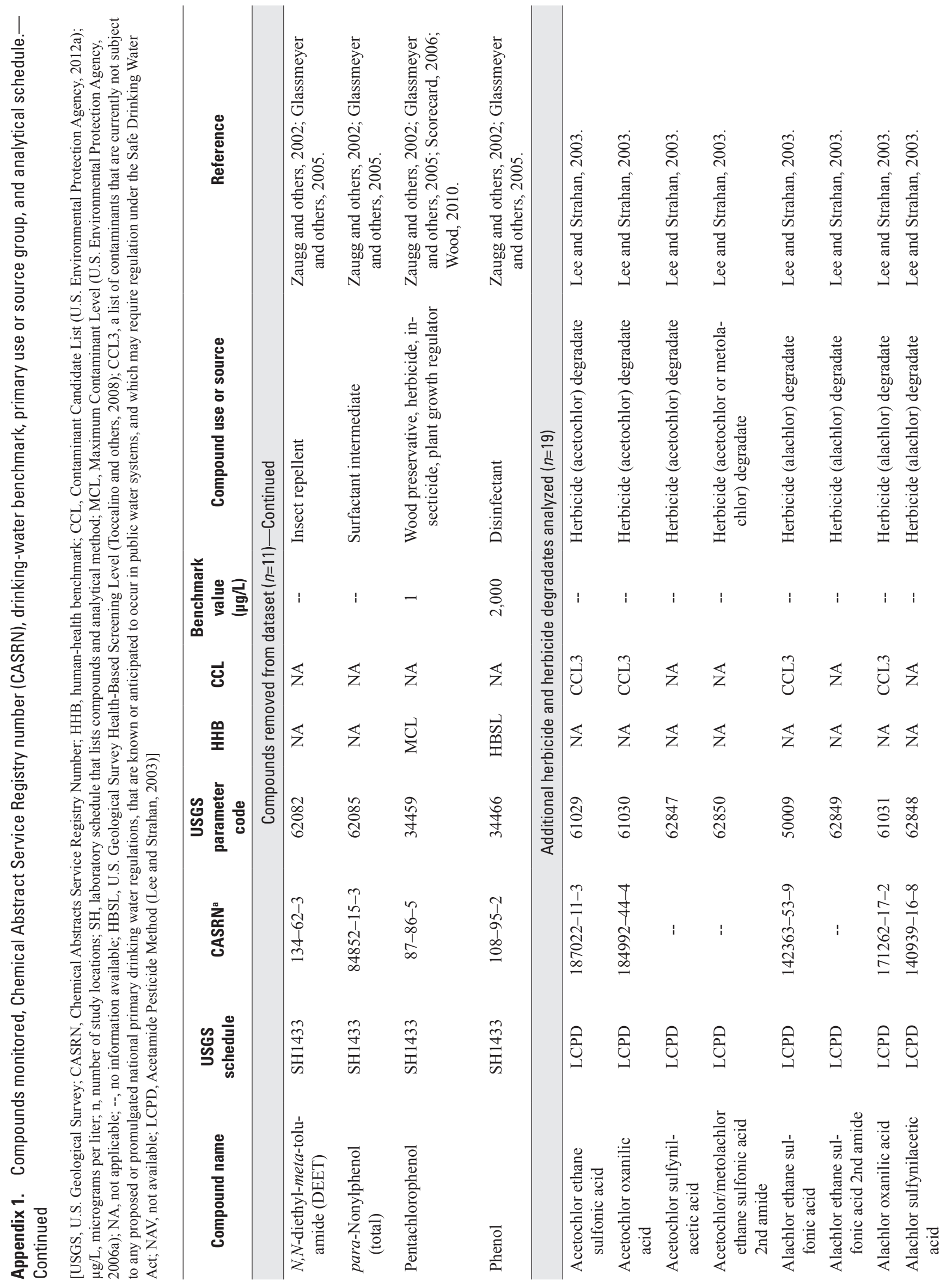




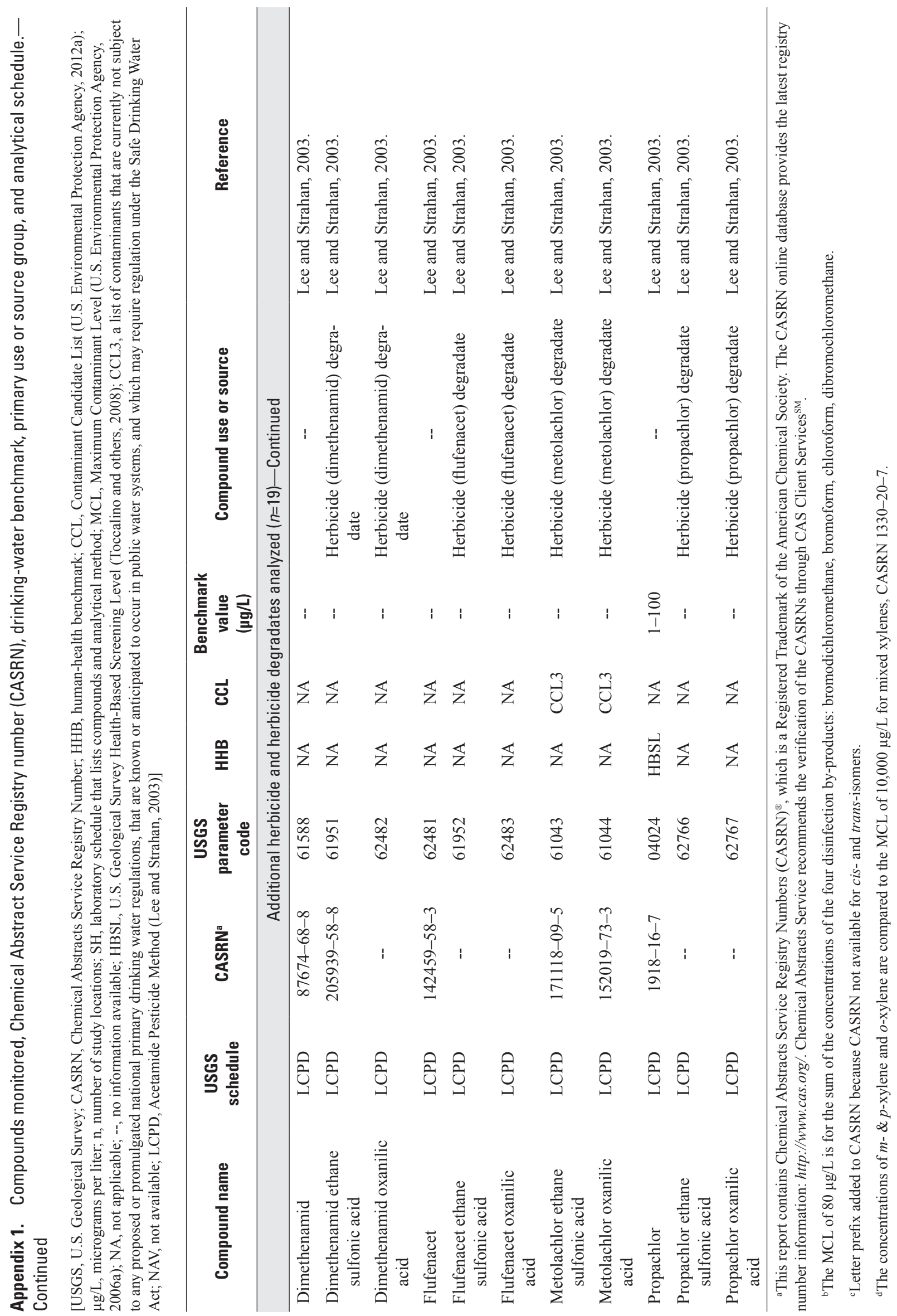


Appendix 2. Summary of the Frequency of Detections in Surface-Water Samples 


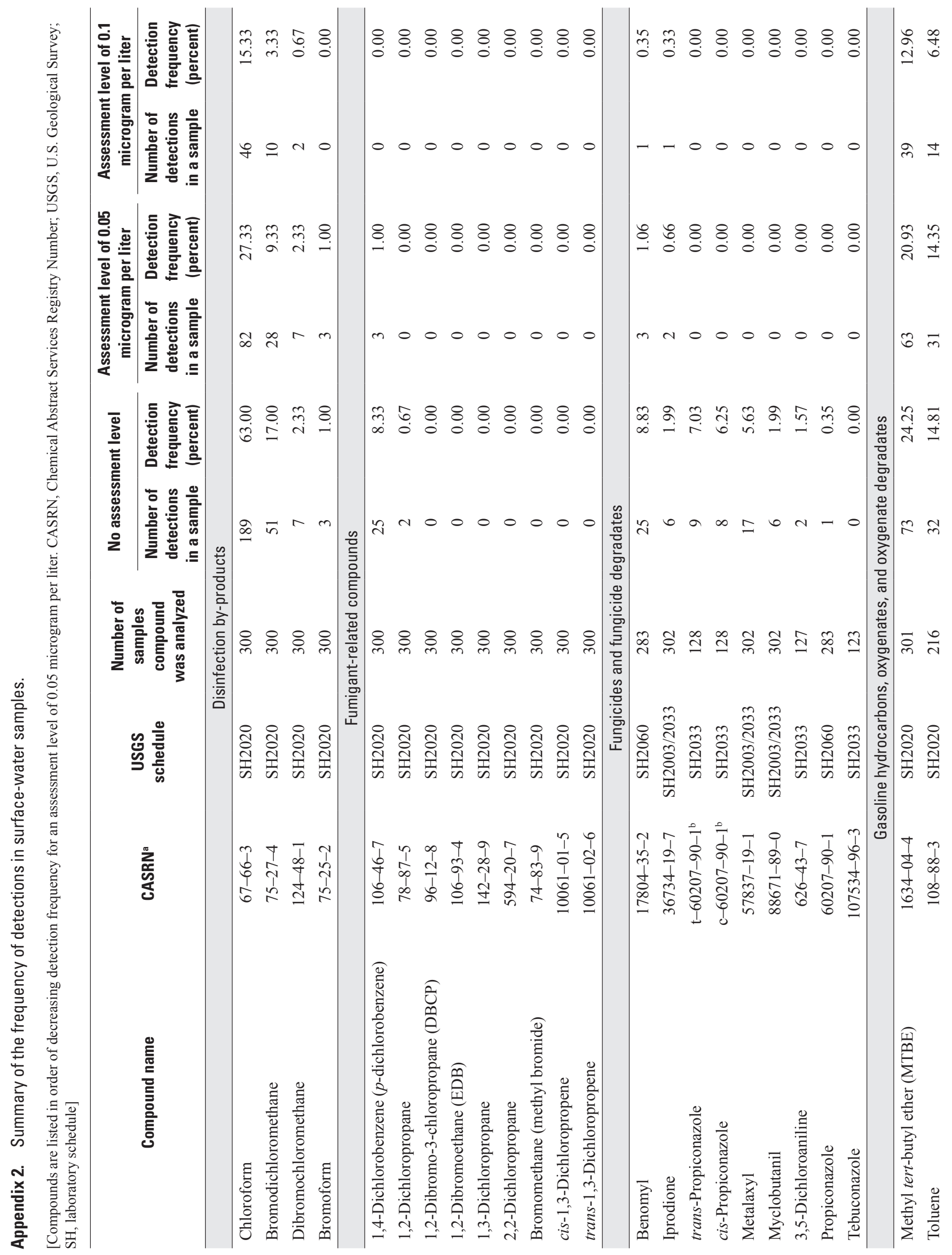




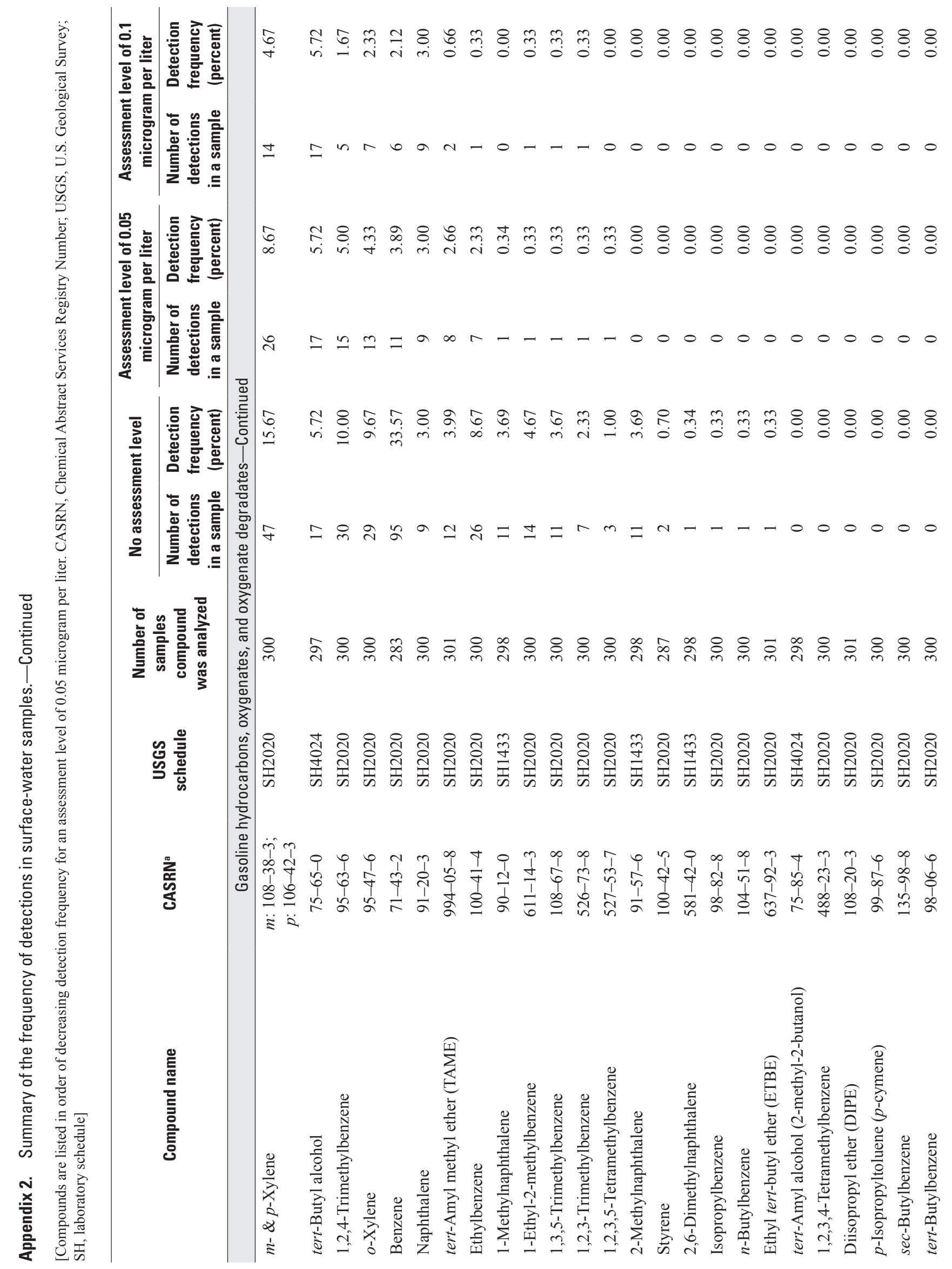




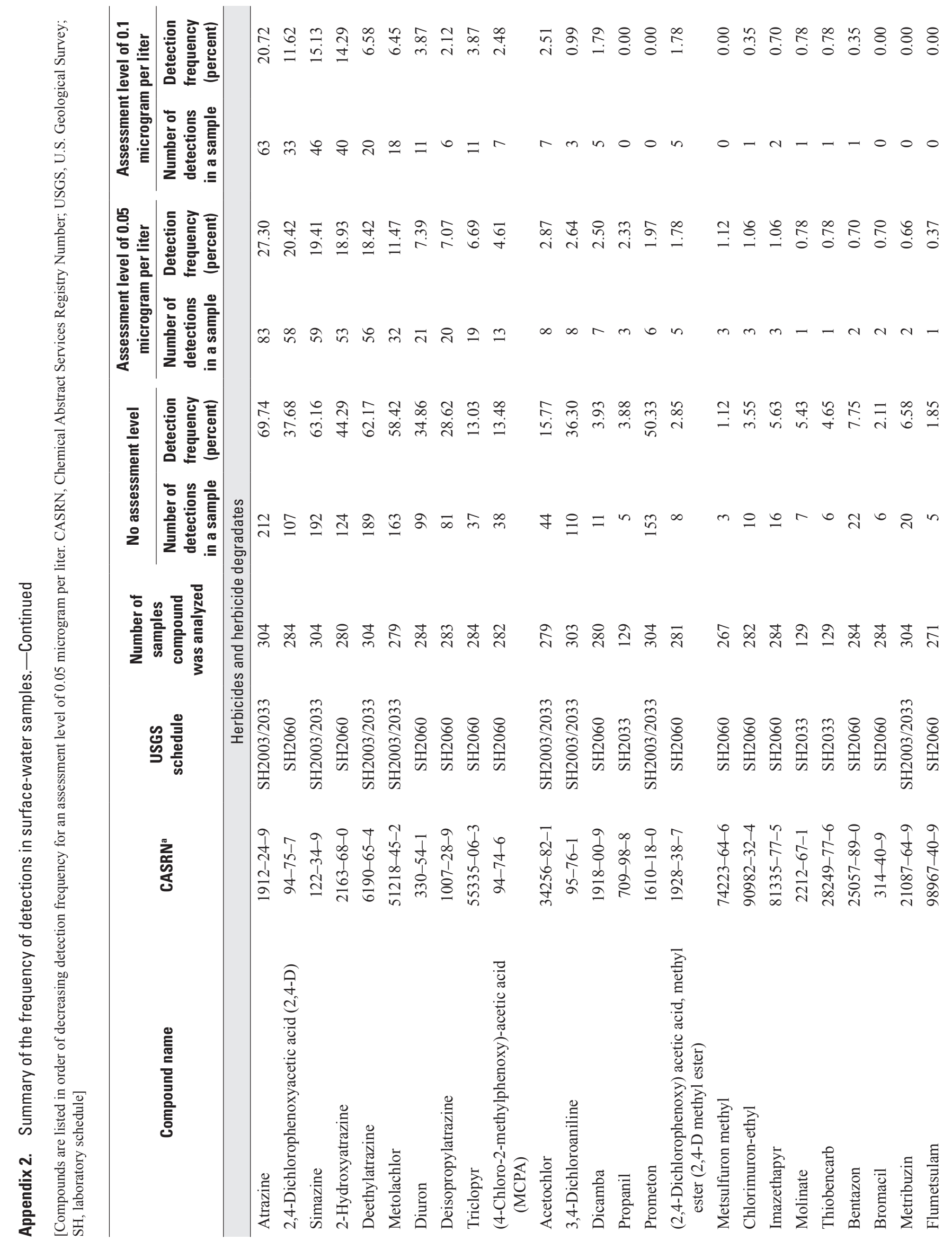




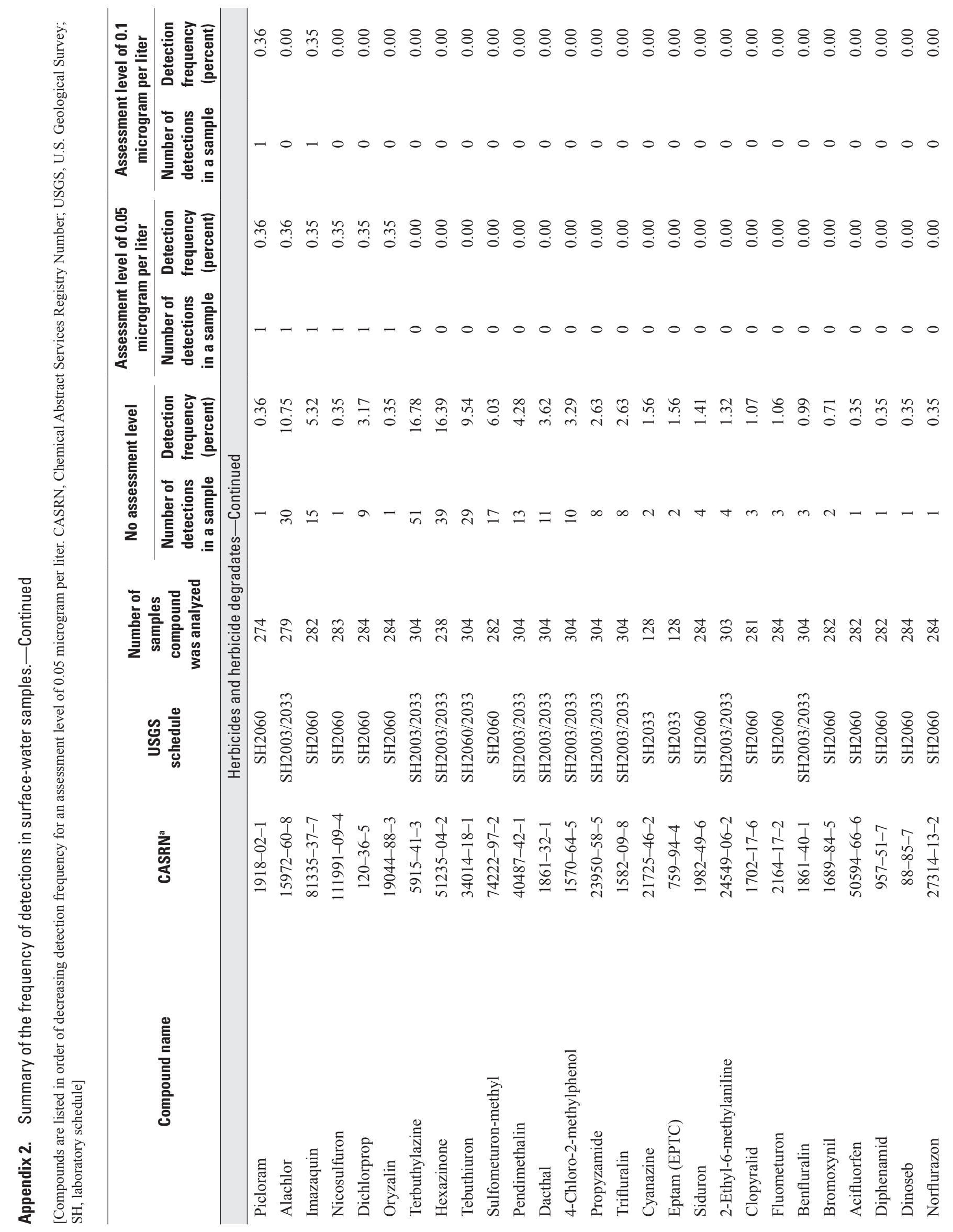




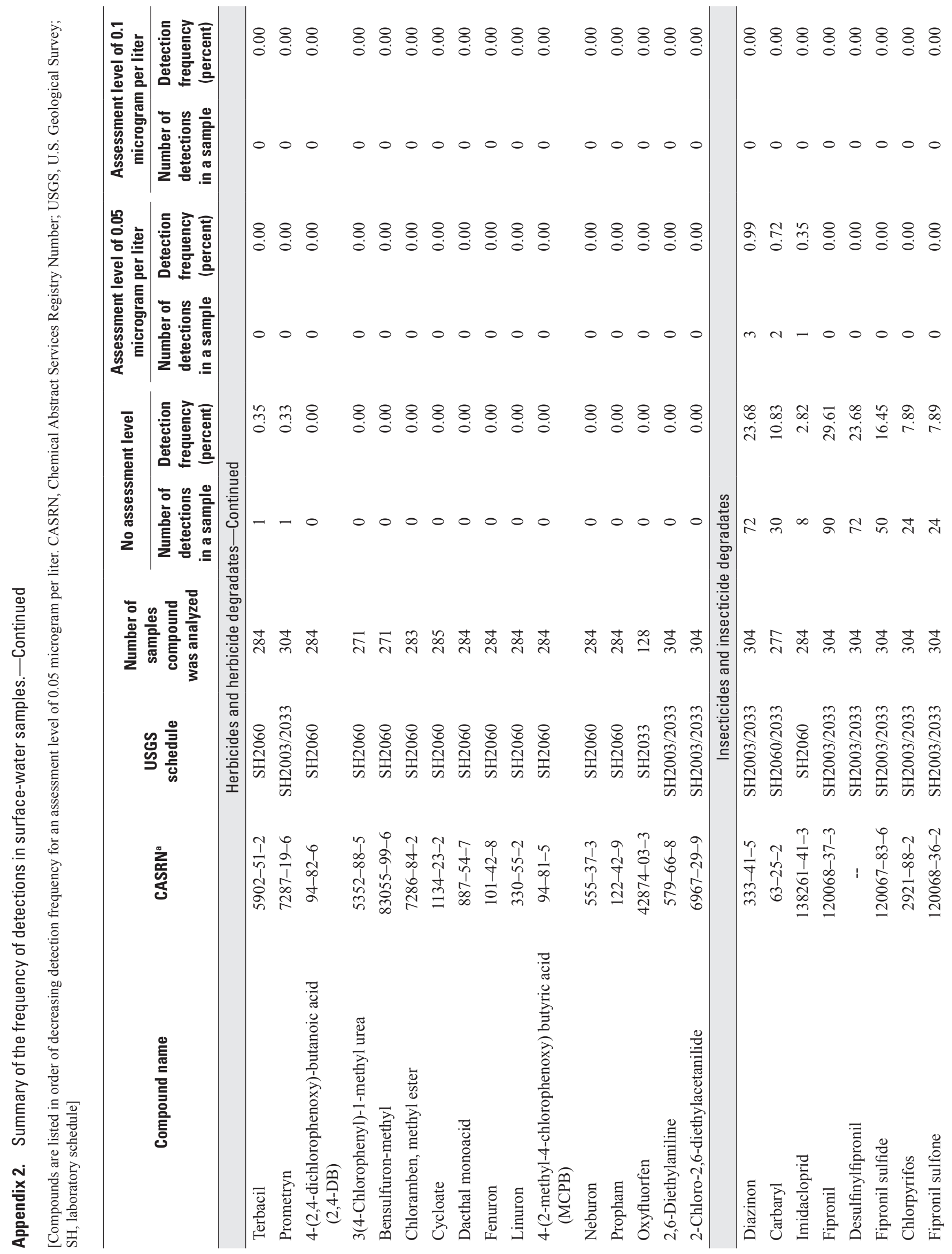




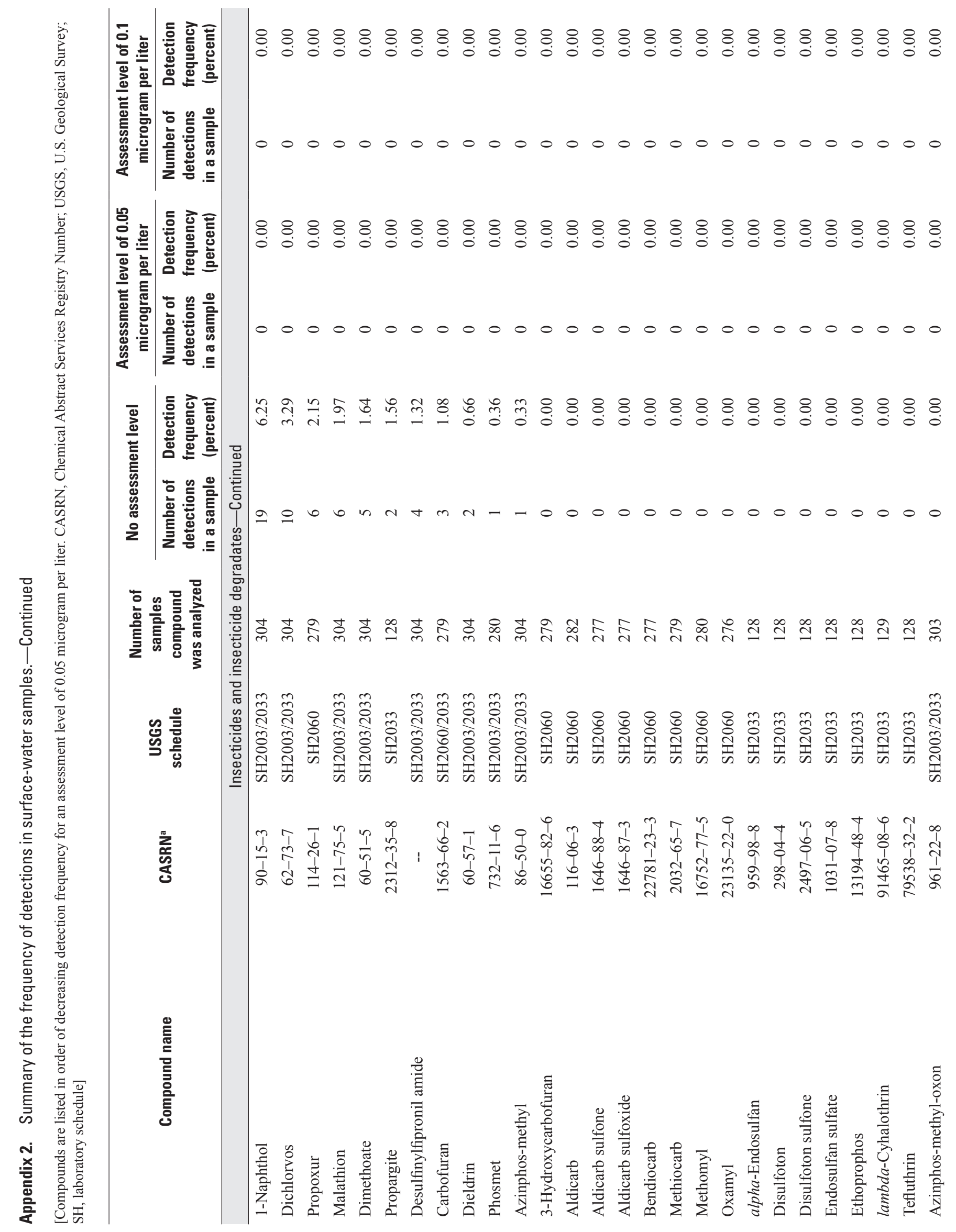




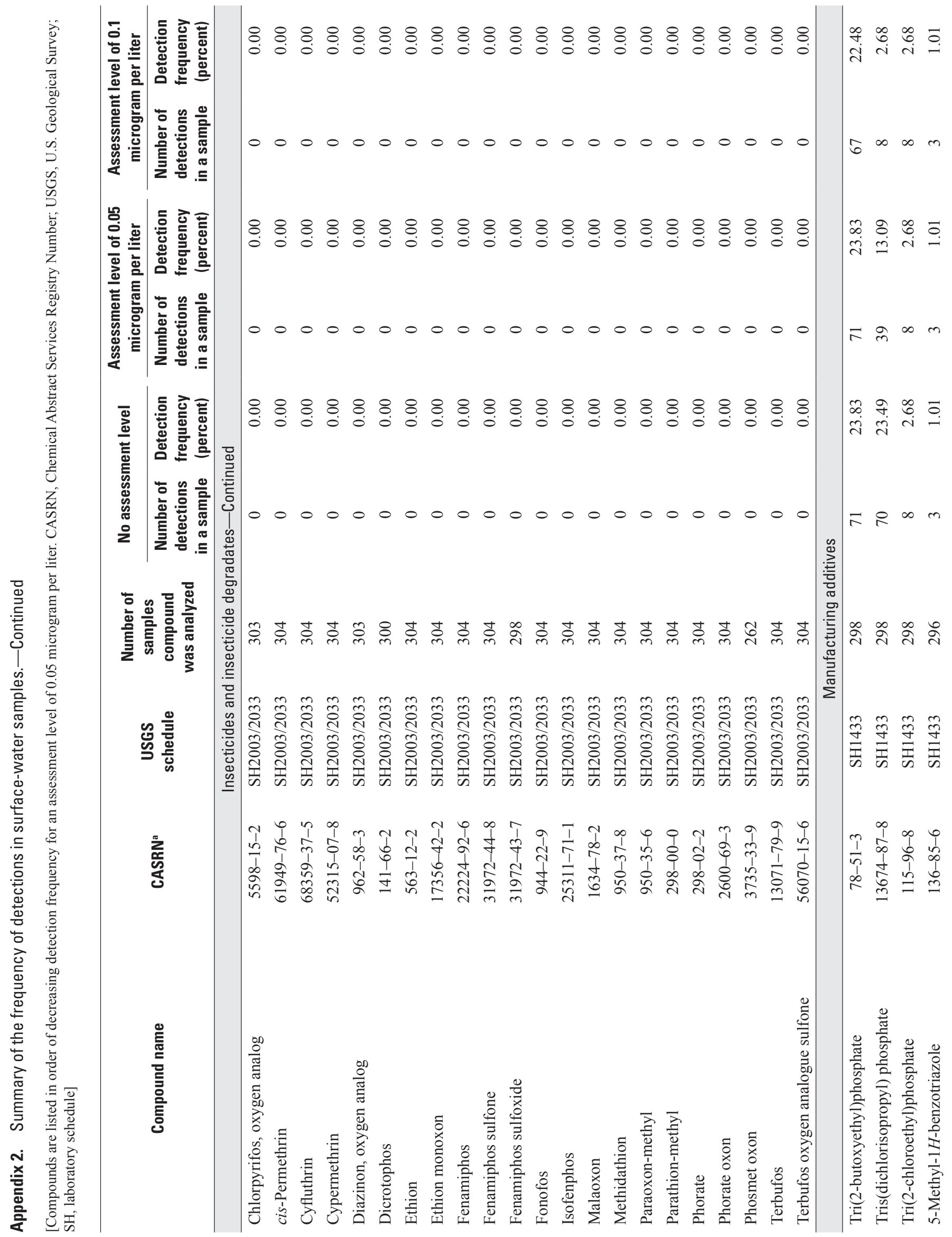




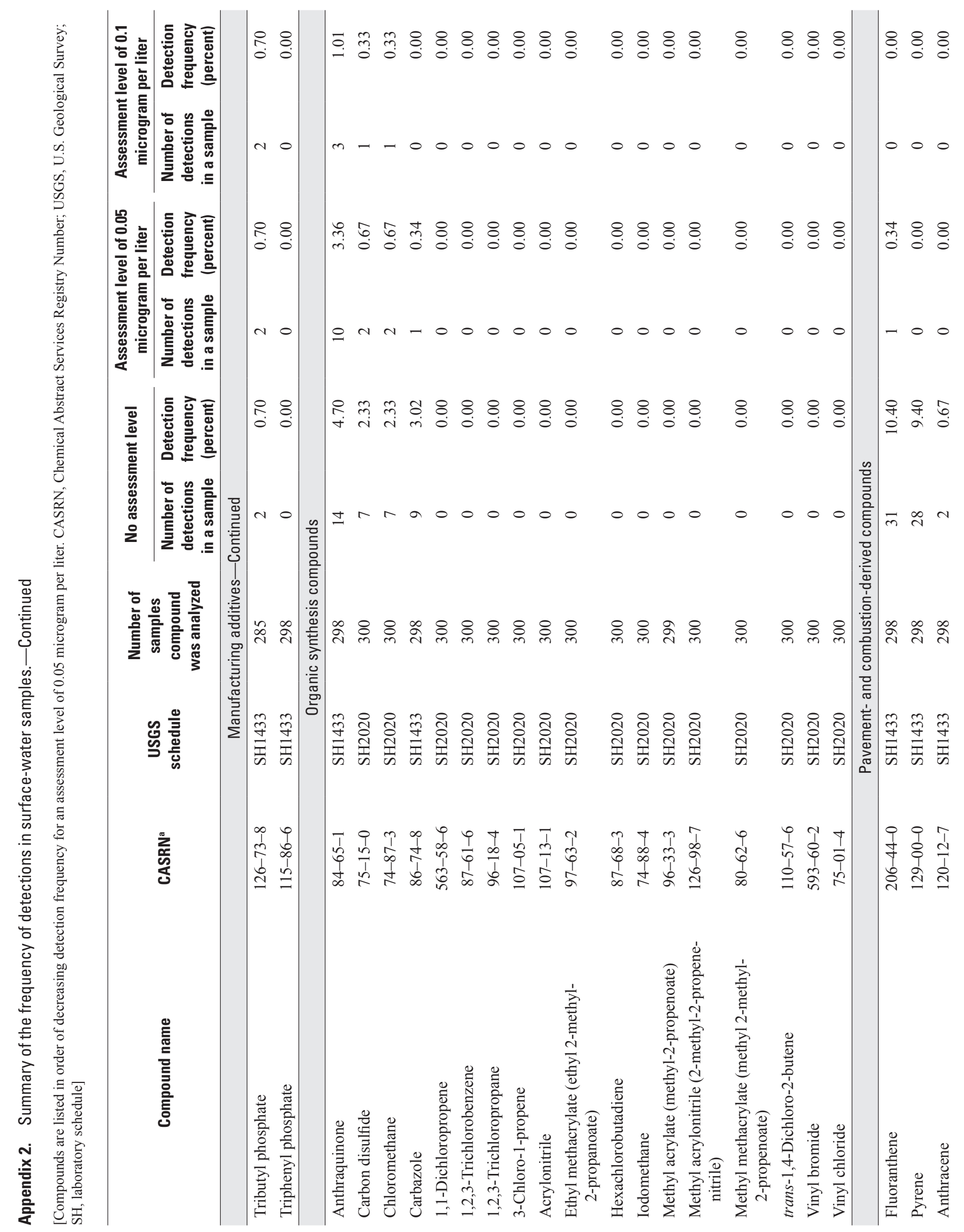




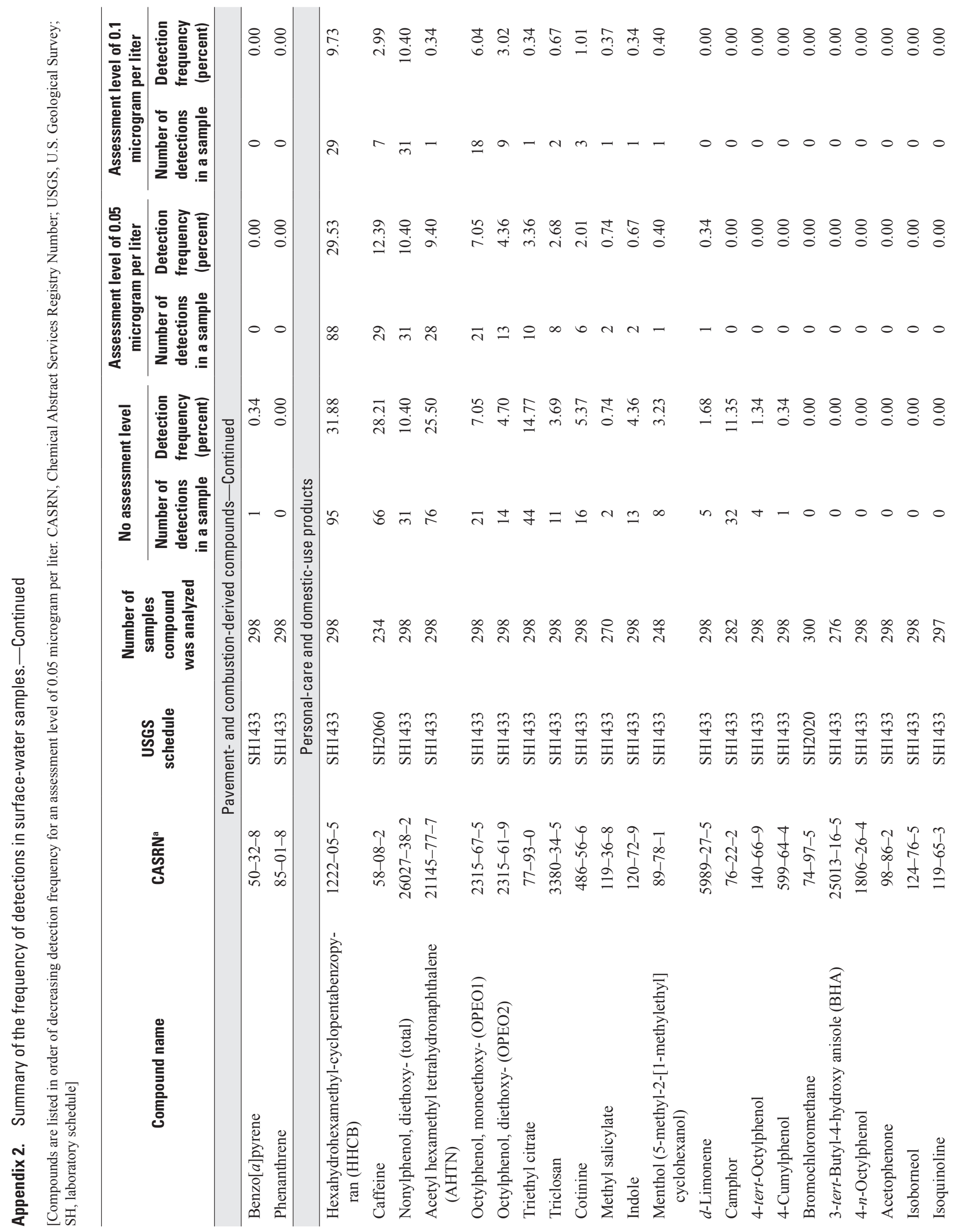




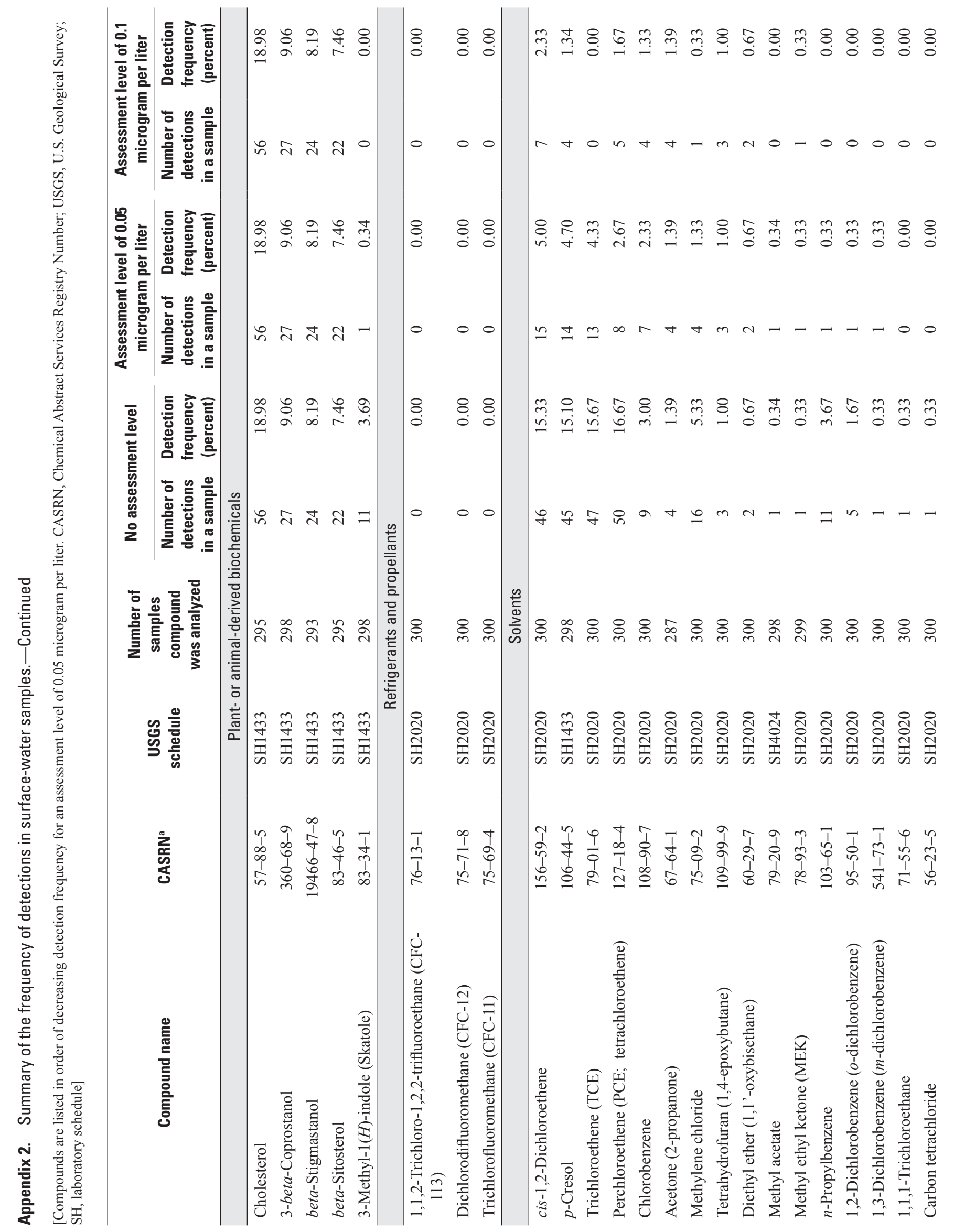




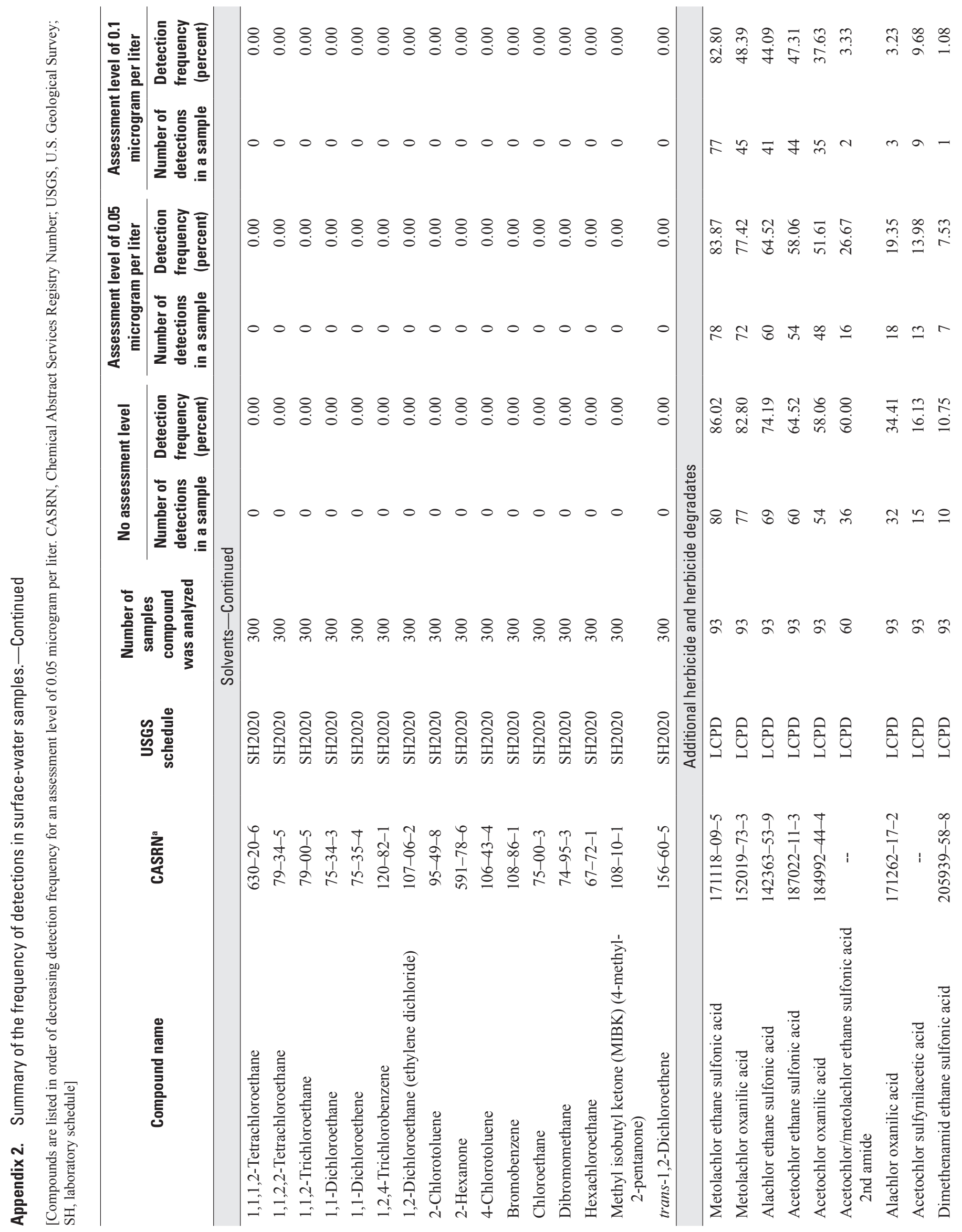




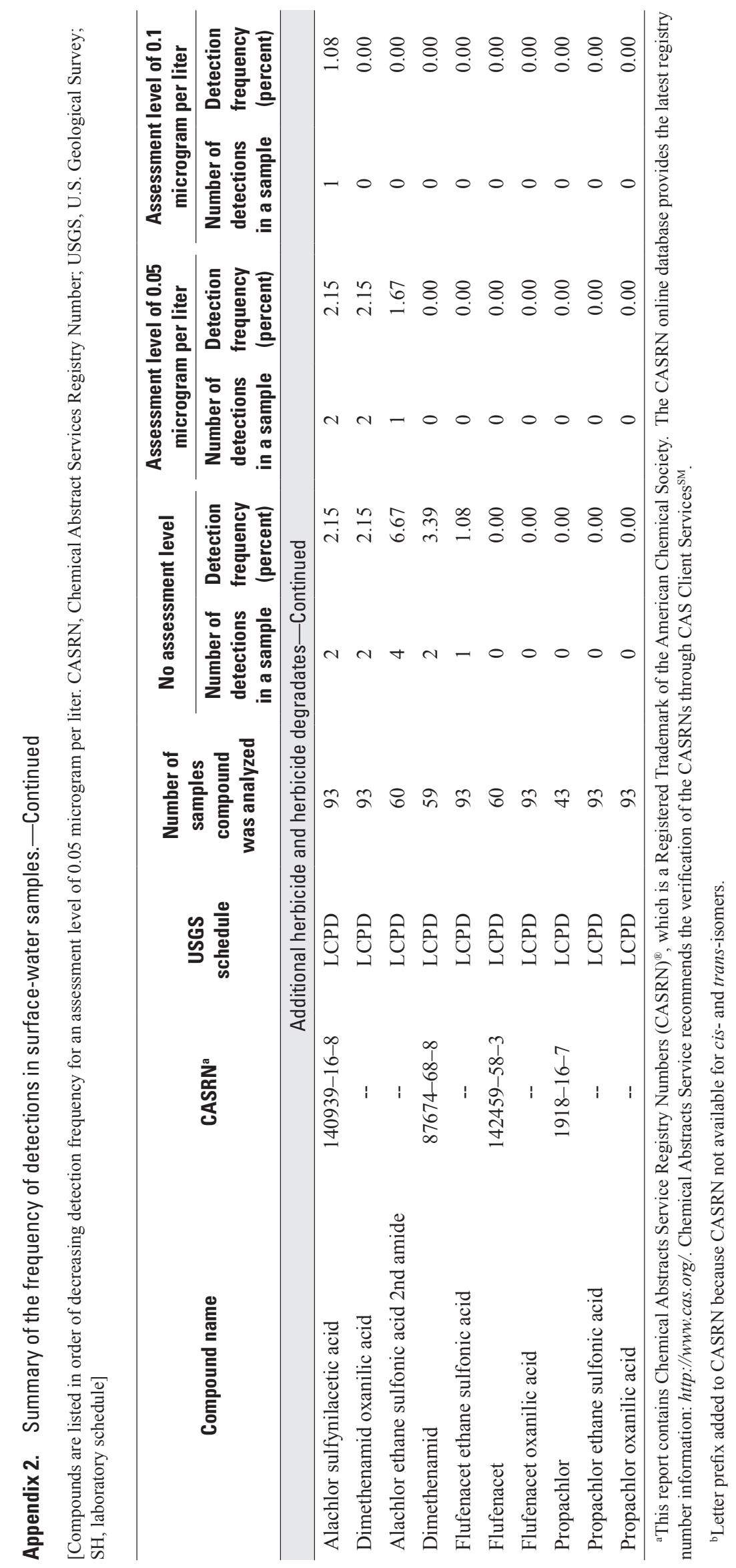




\section{Appendix 3. Summary of Frequency of Detections in Groundwater Samples}




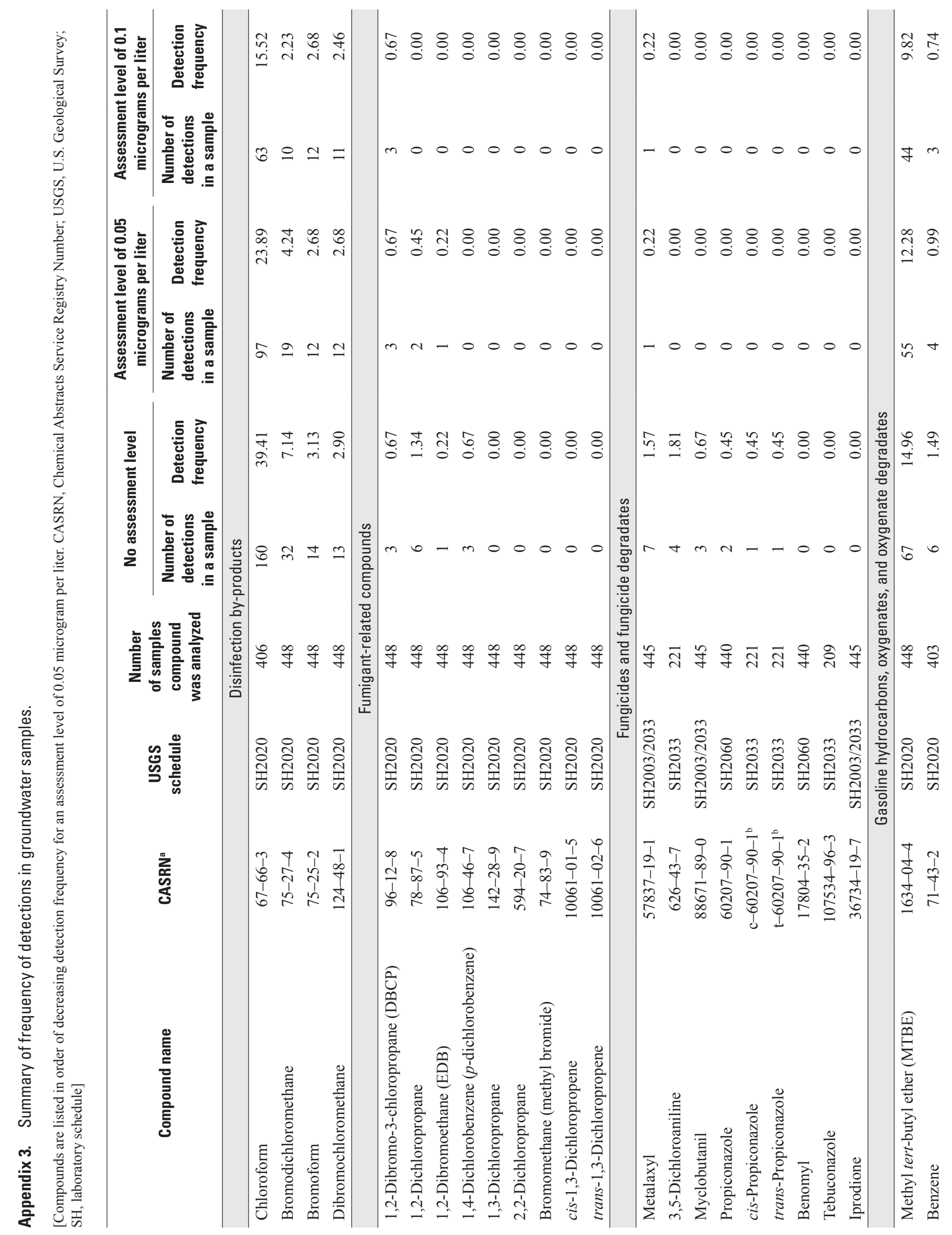




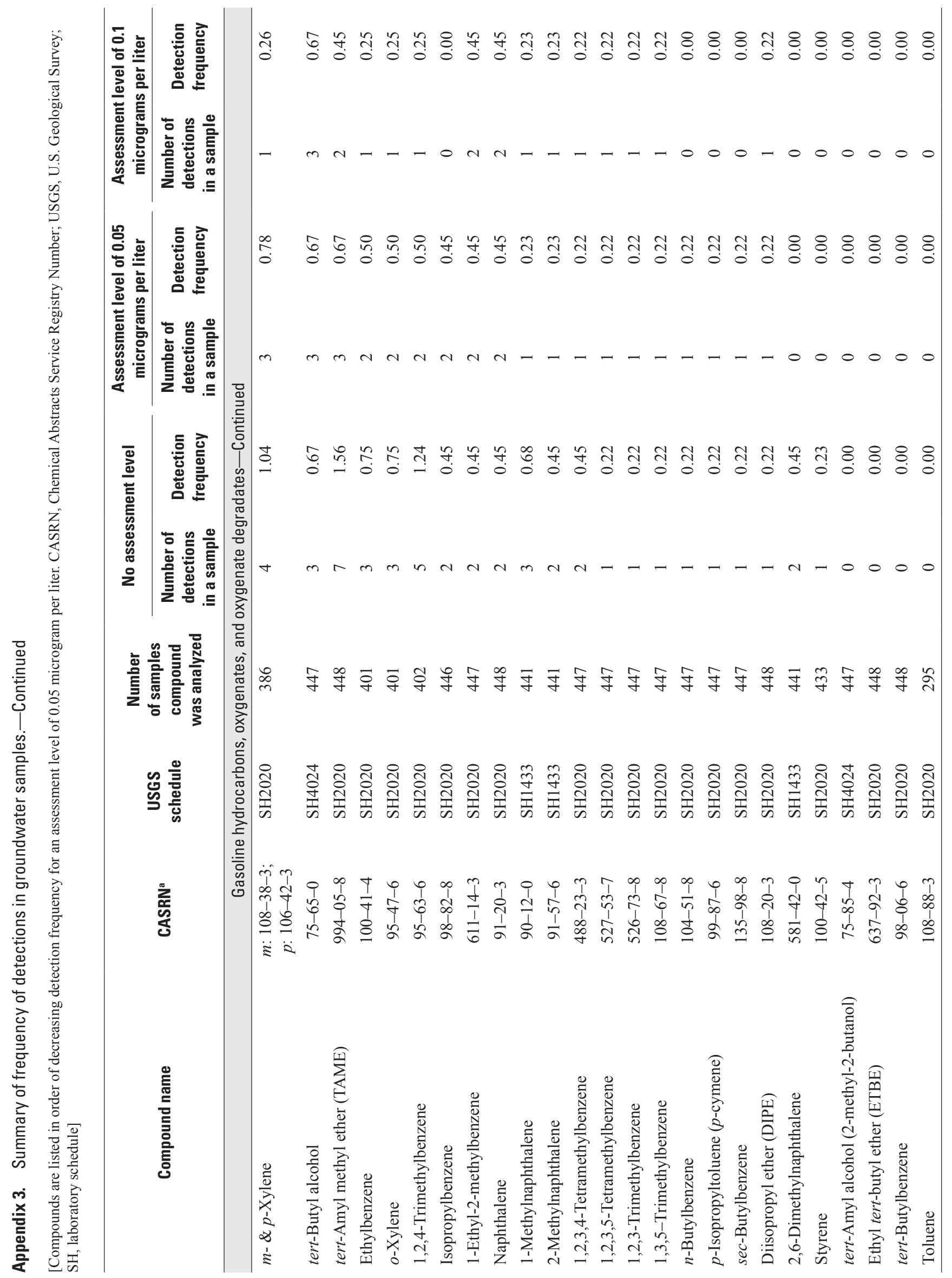




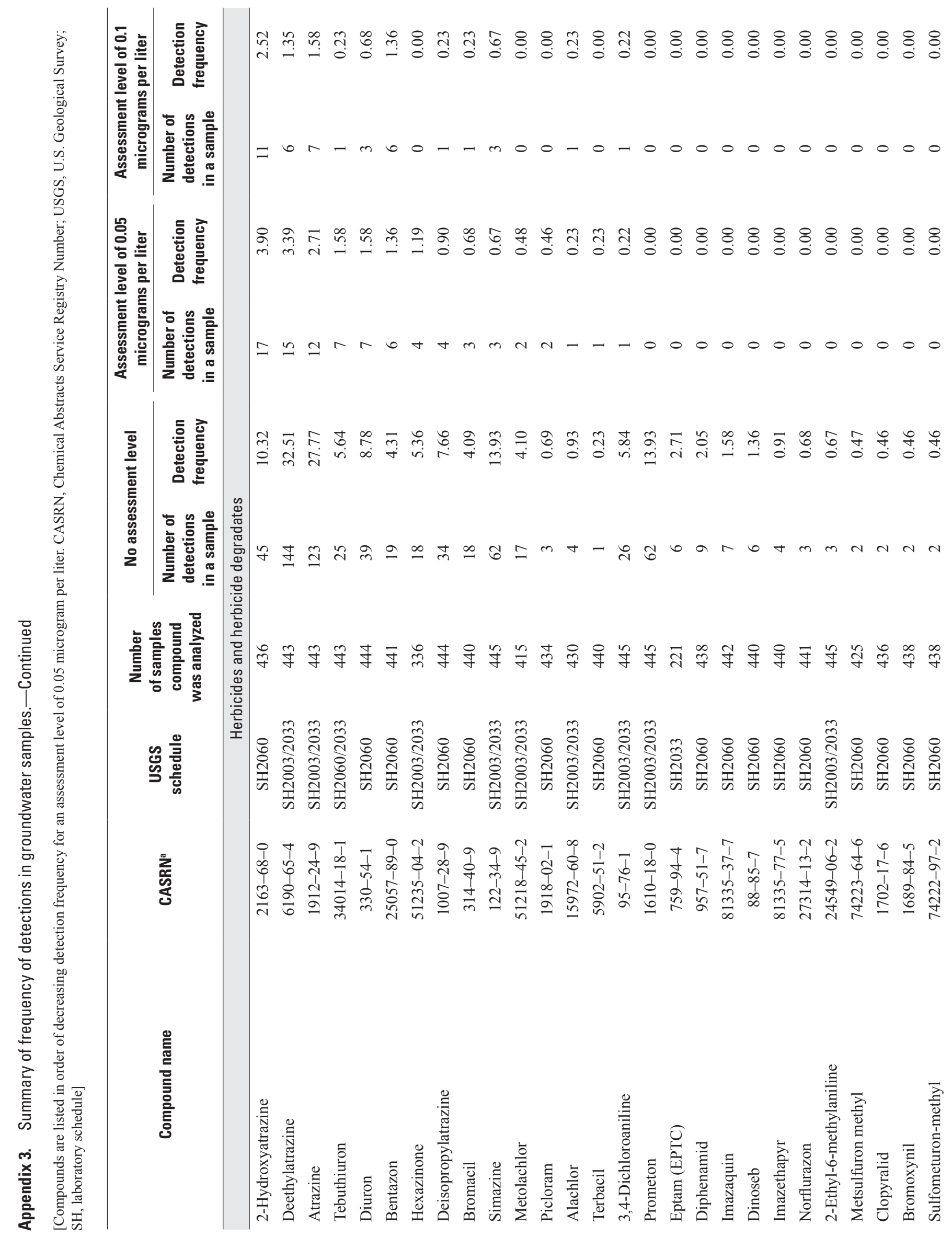




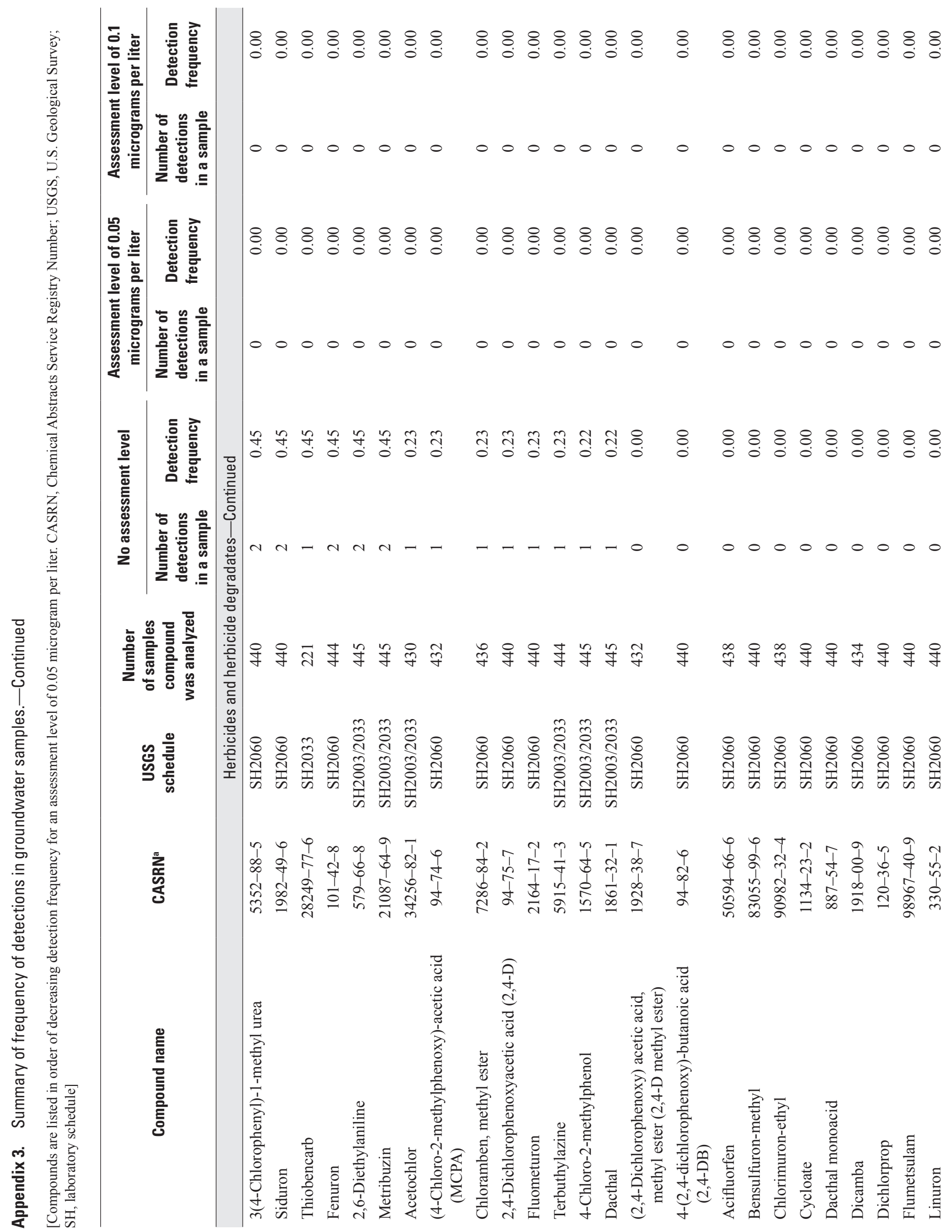




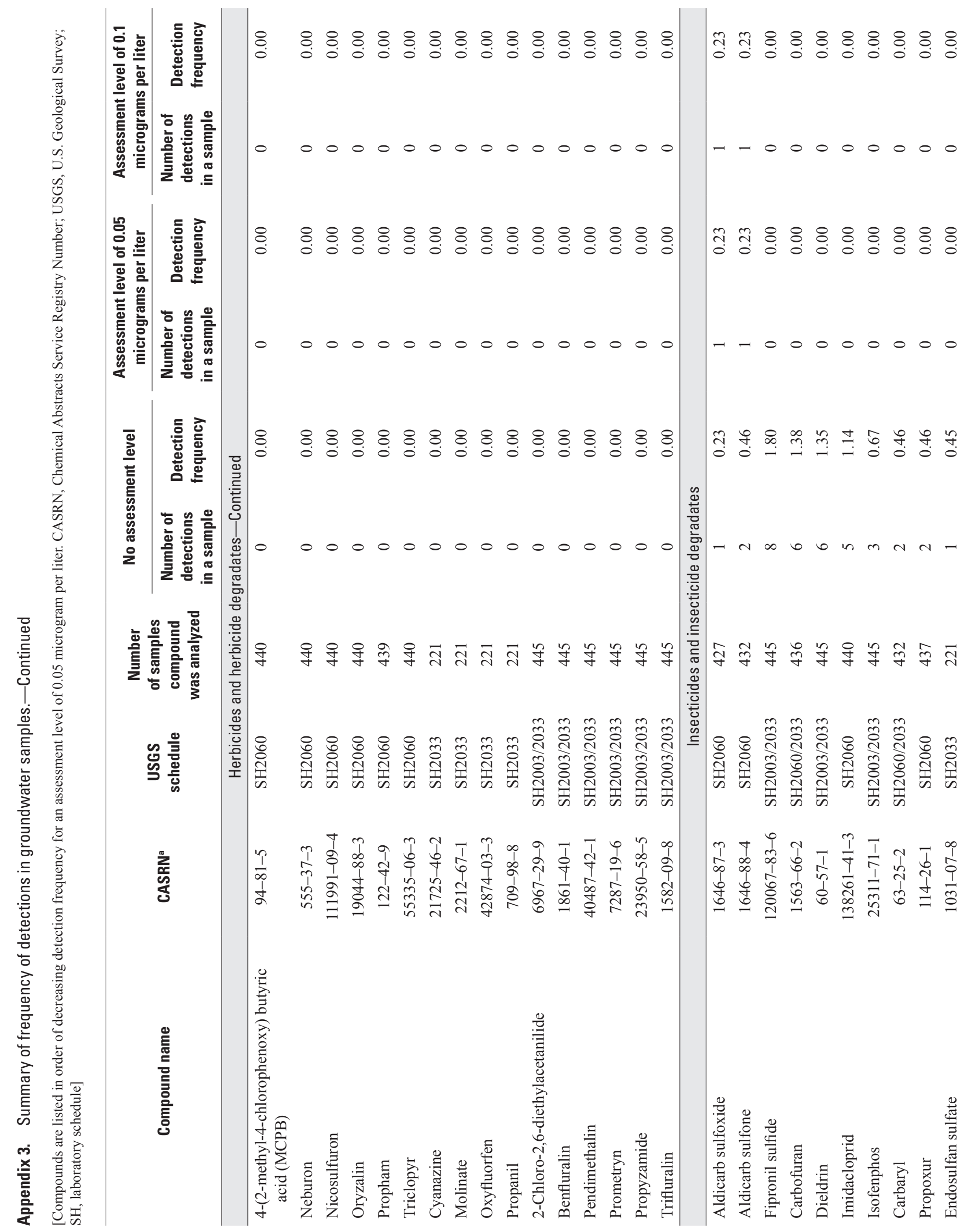




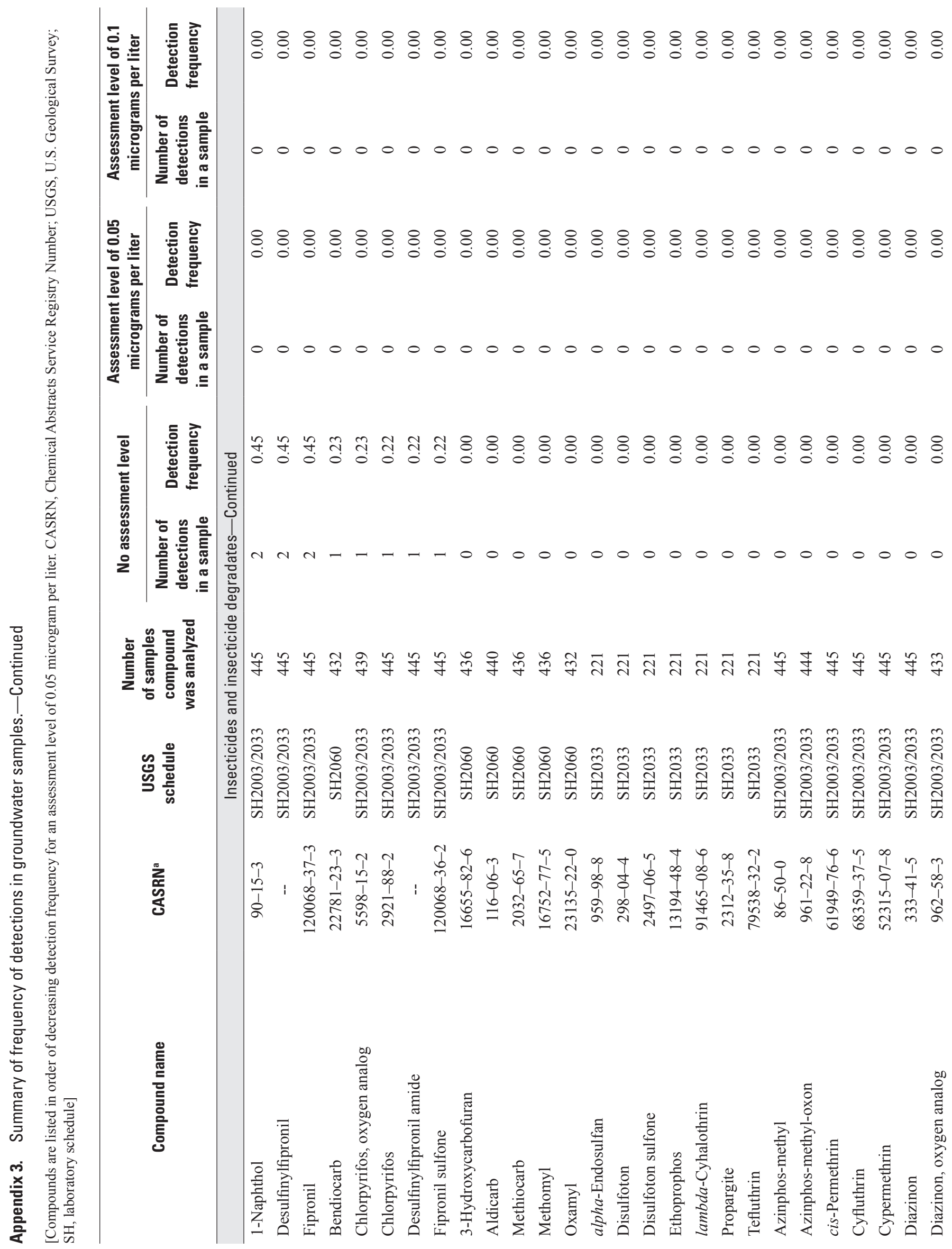




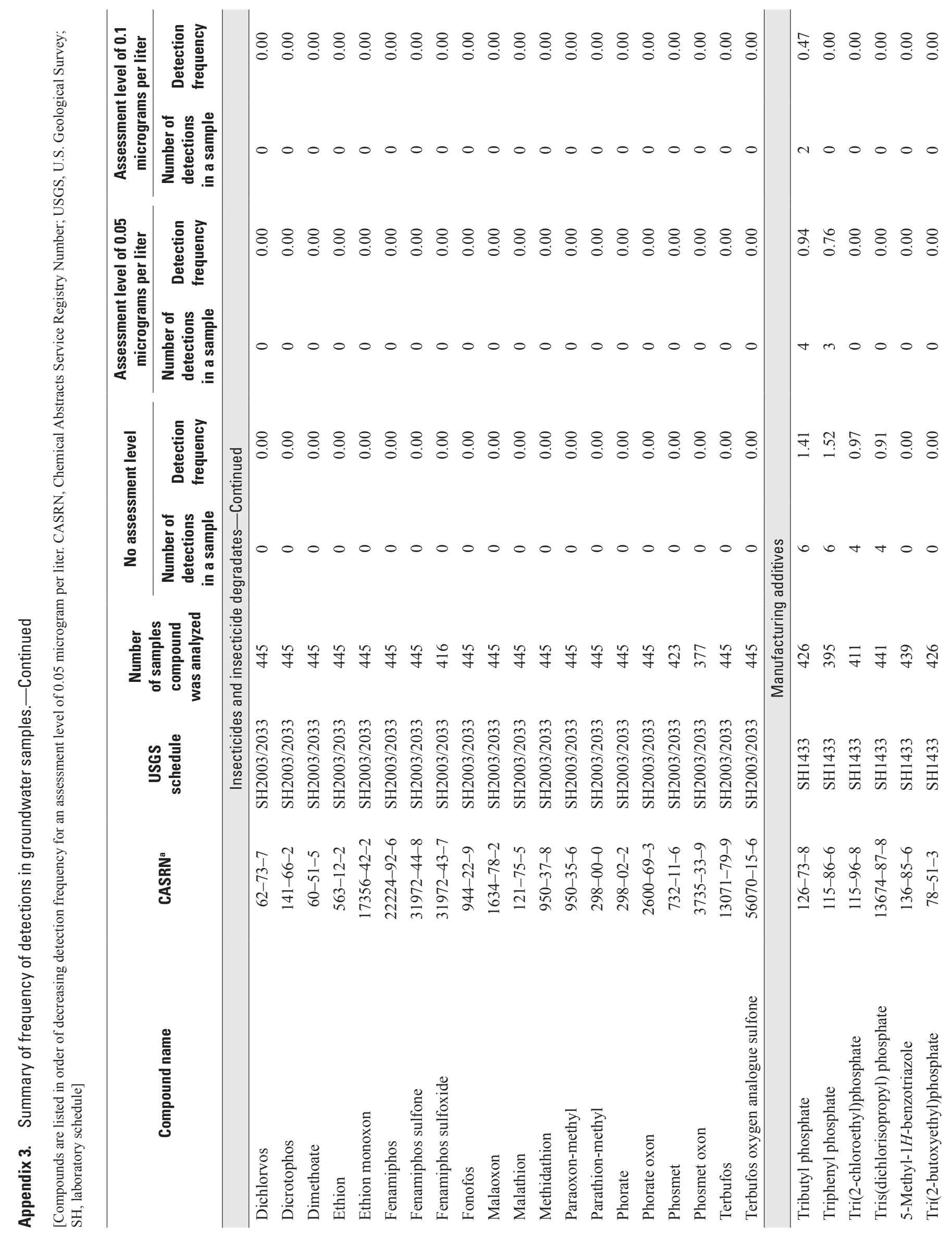




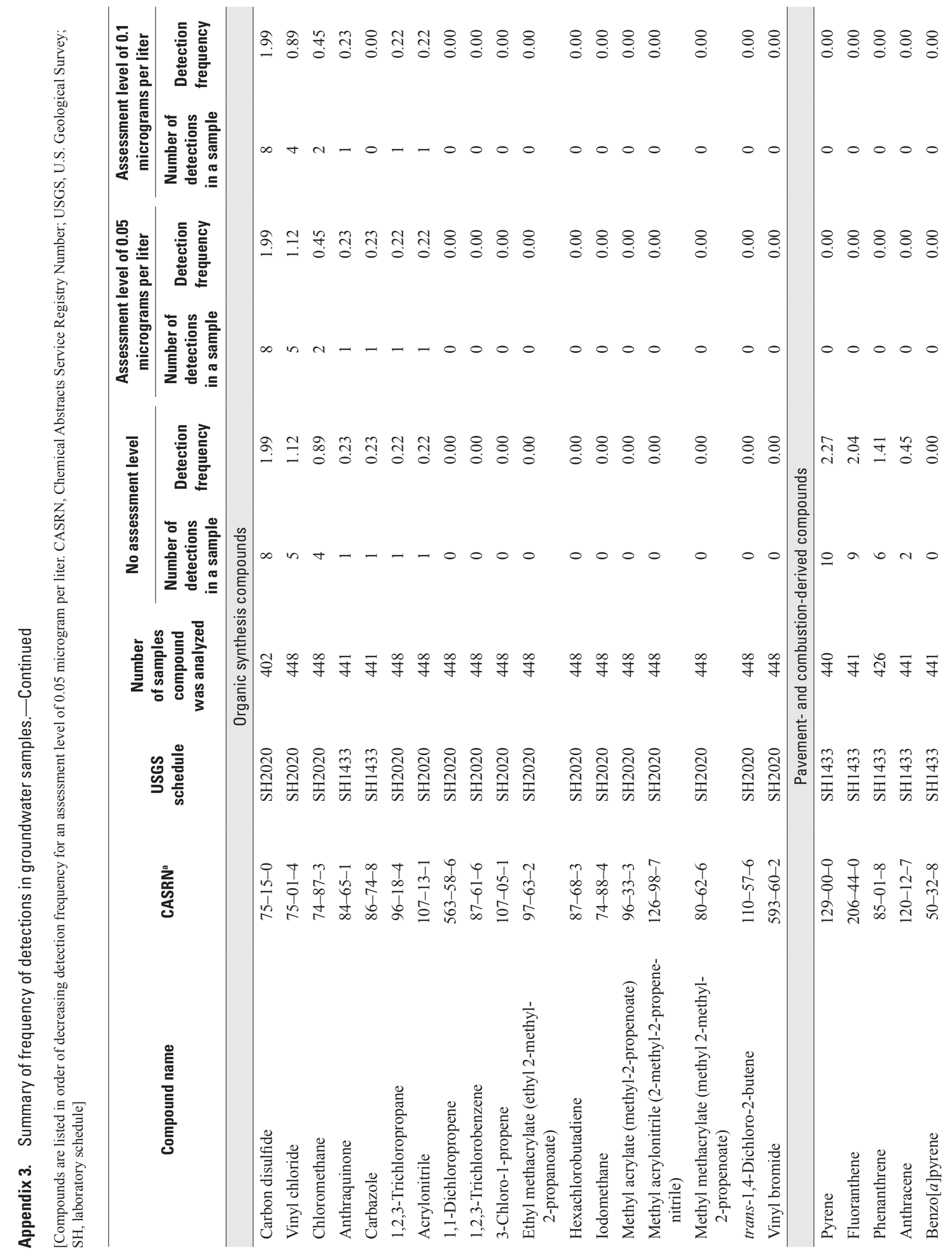




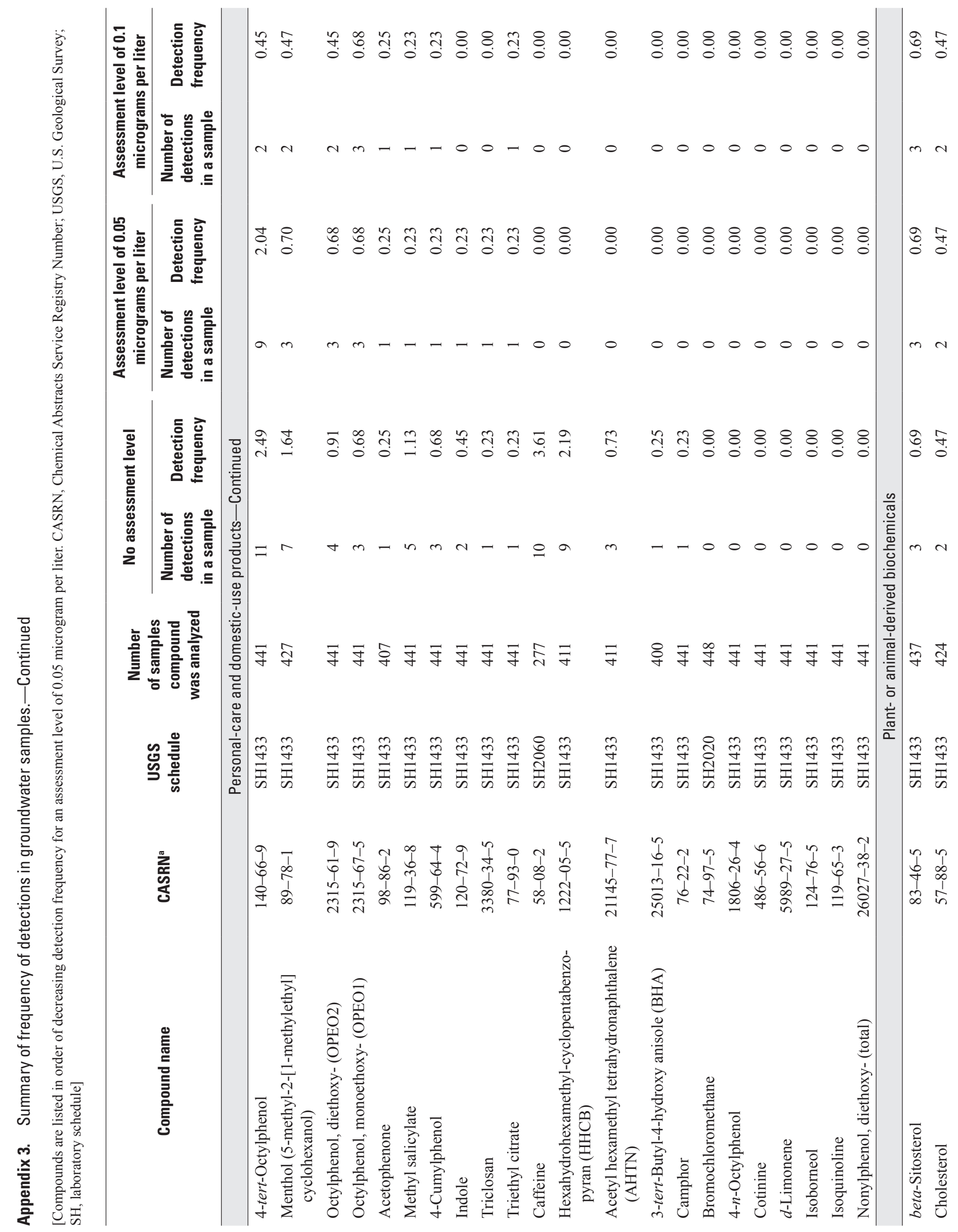




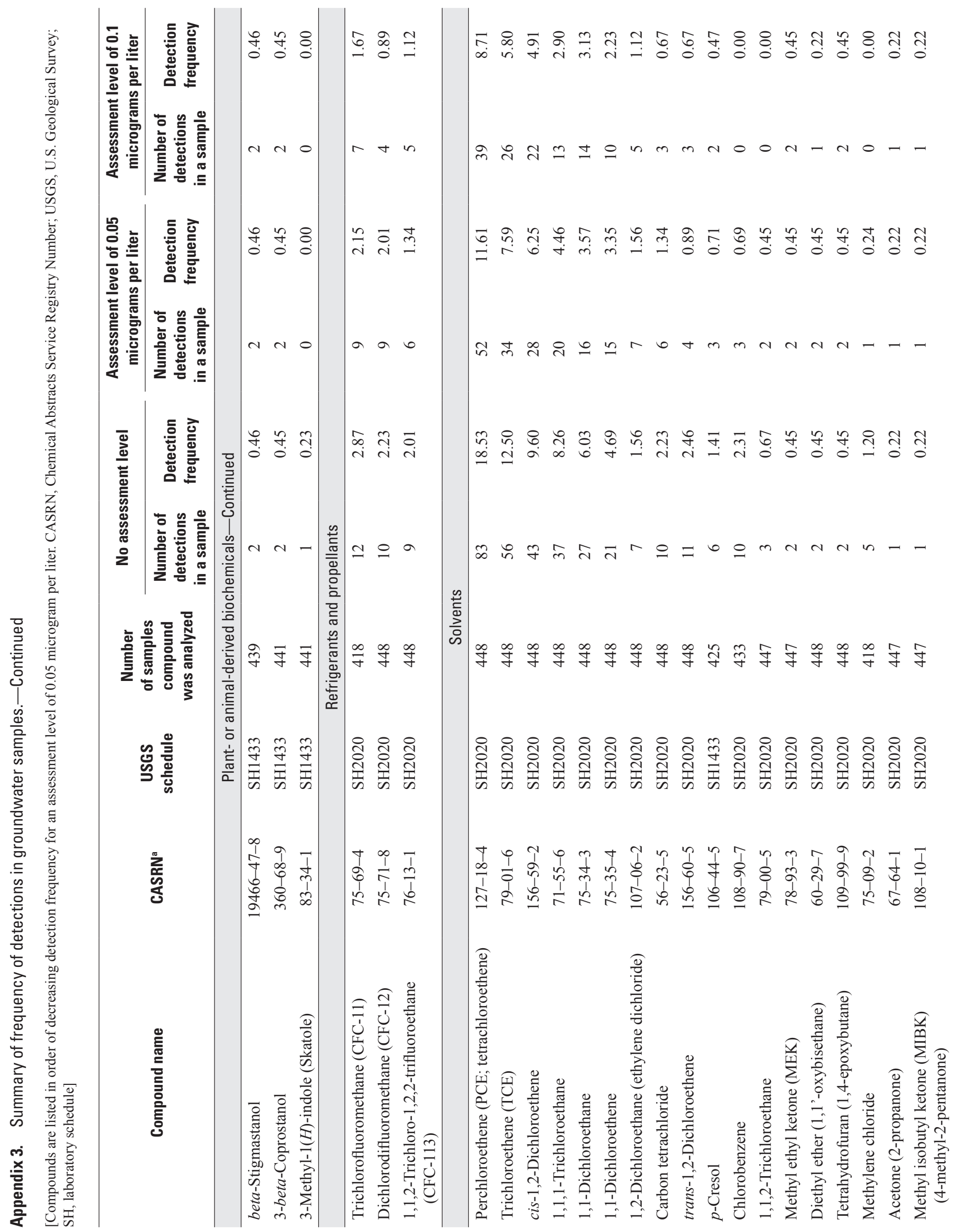




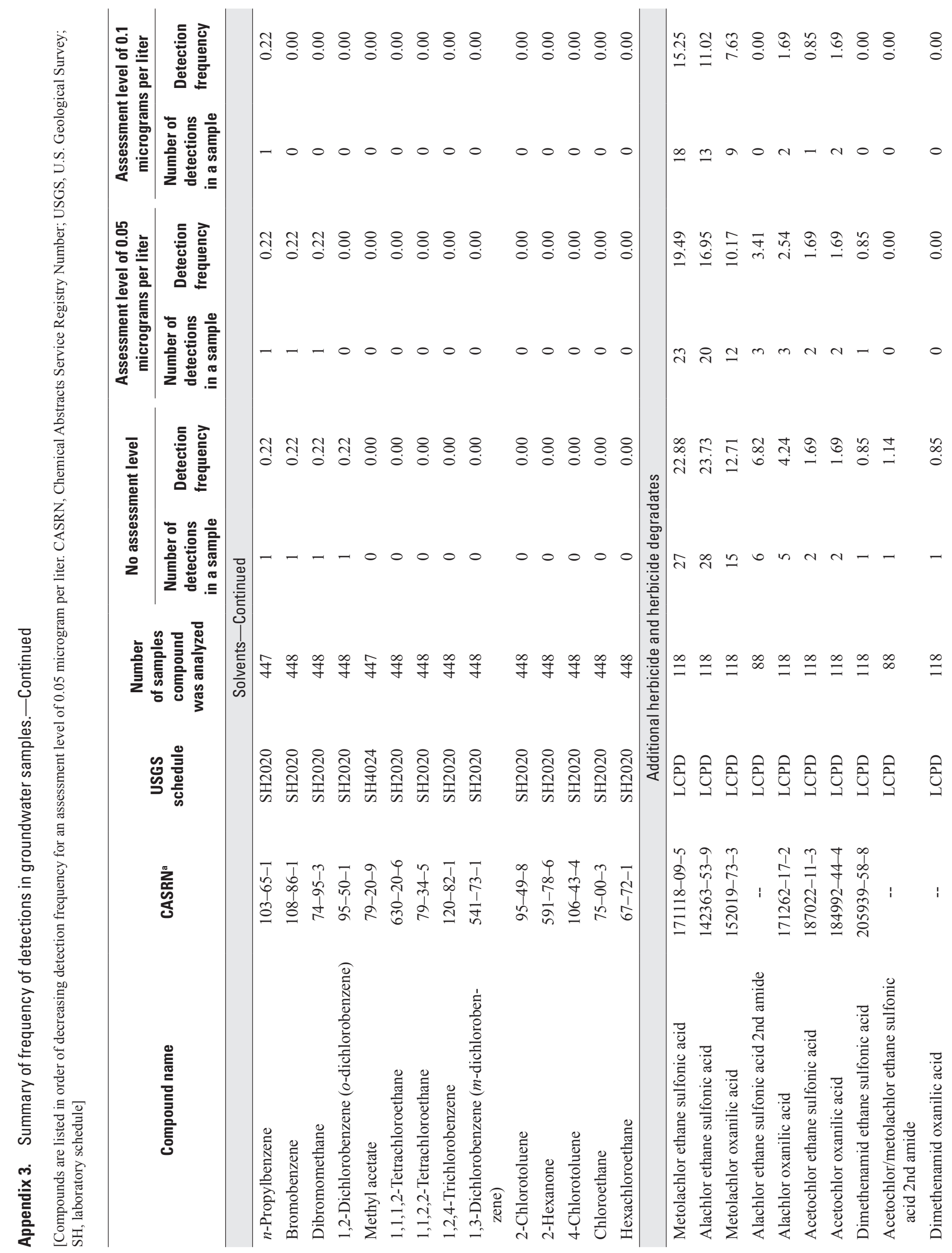




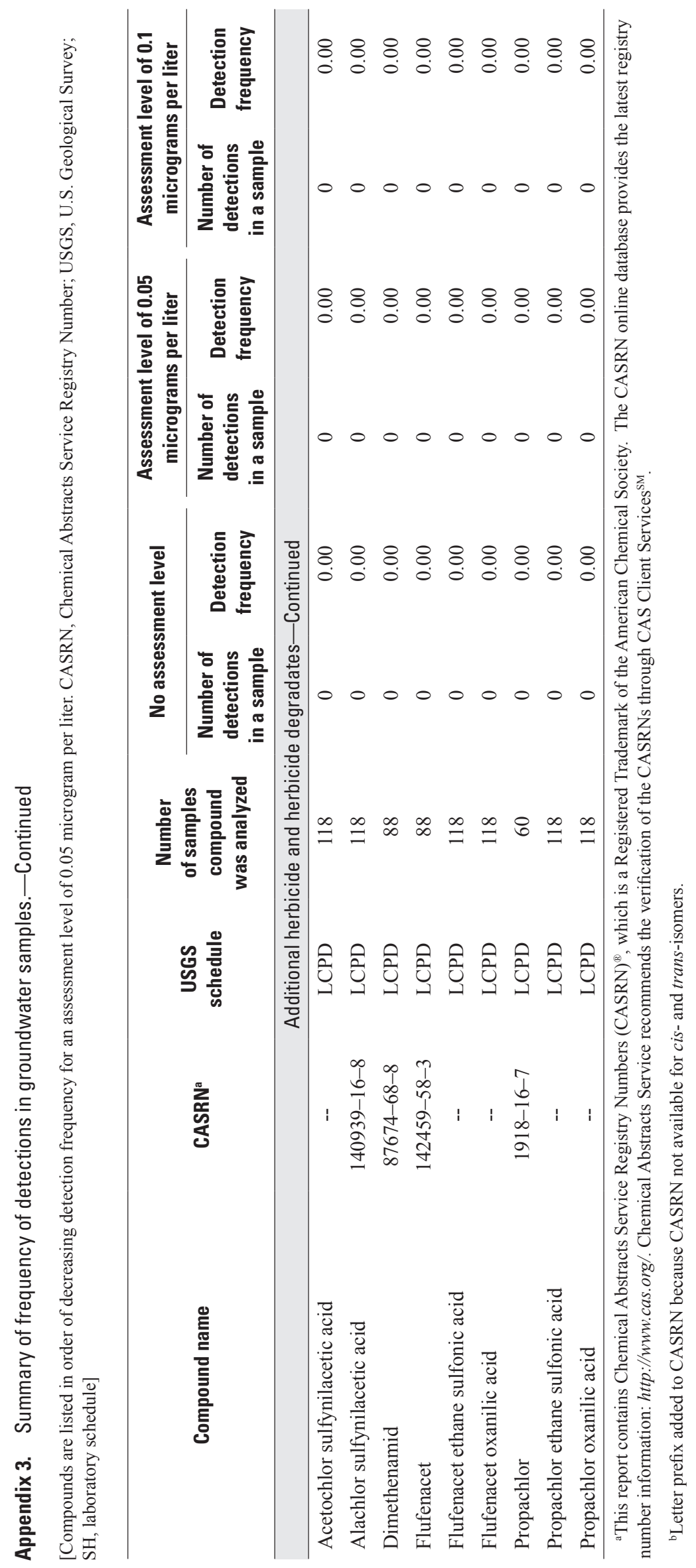




\section{Appendix 4. Qualified Concentrations of Compounds Monitored in Surface Water During 2002-10 by Primary Use Group And Human-Health Benchmarks (Where Applicable)}

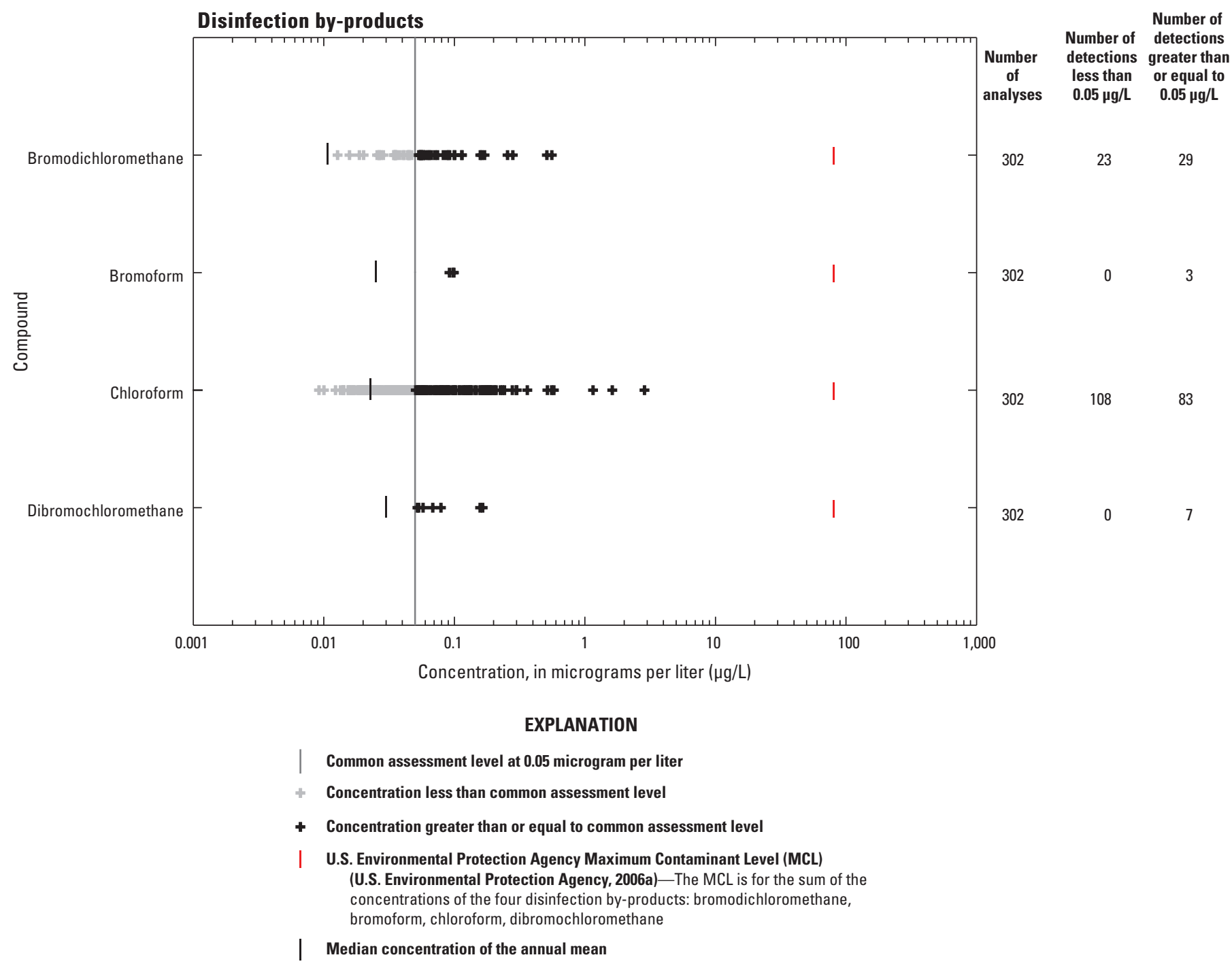

Figure 4-1. Qualified concentrations of disinfection by-products in surface water, 2002-10. 


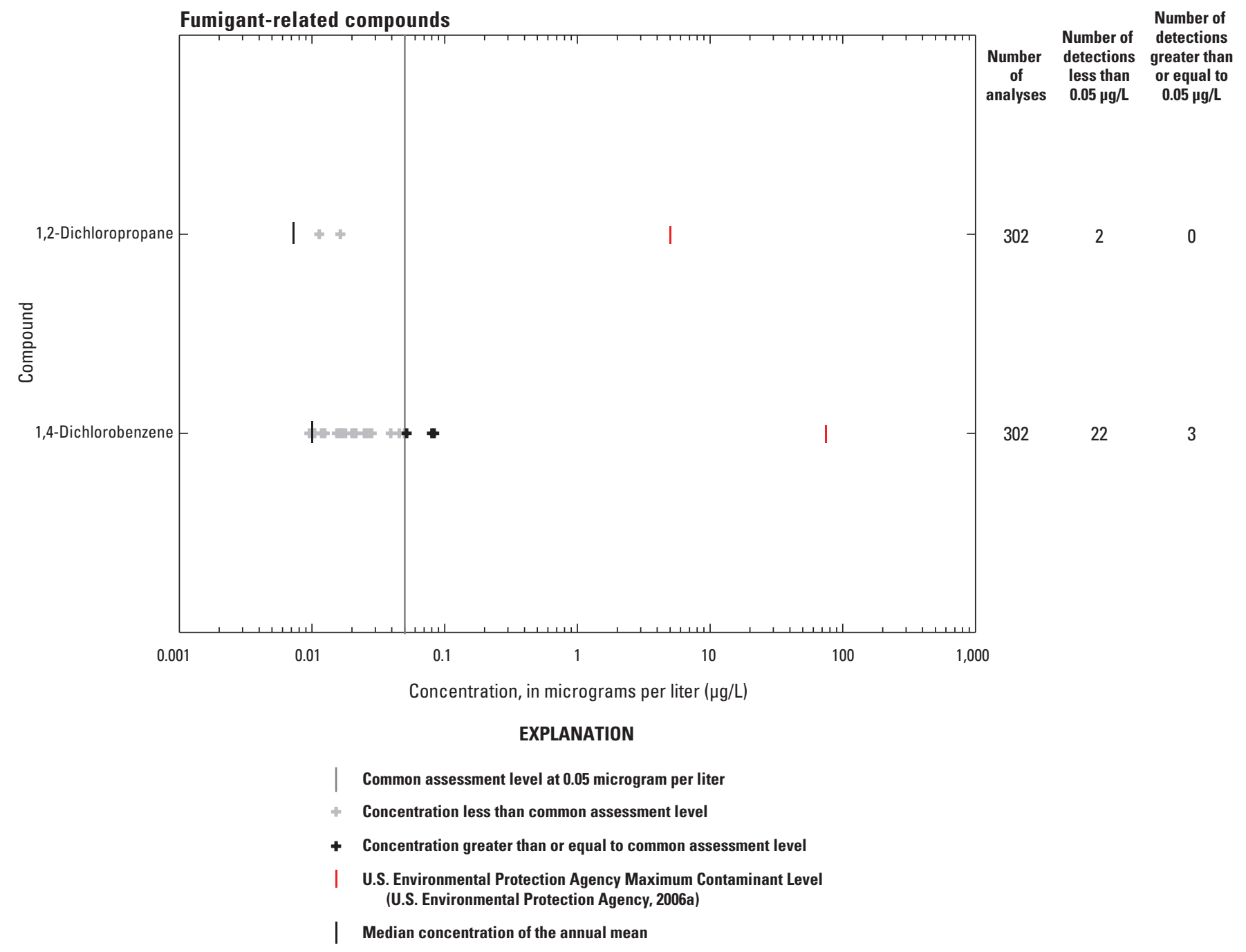

Figure 4-2. Qualified concentrations of fumigant-related compounds in surface water, 2002-10. 


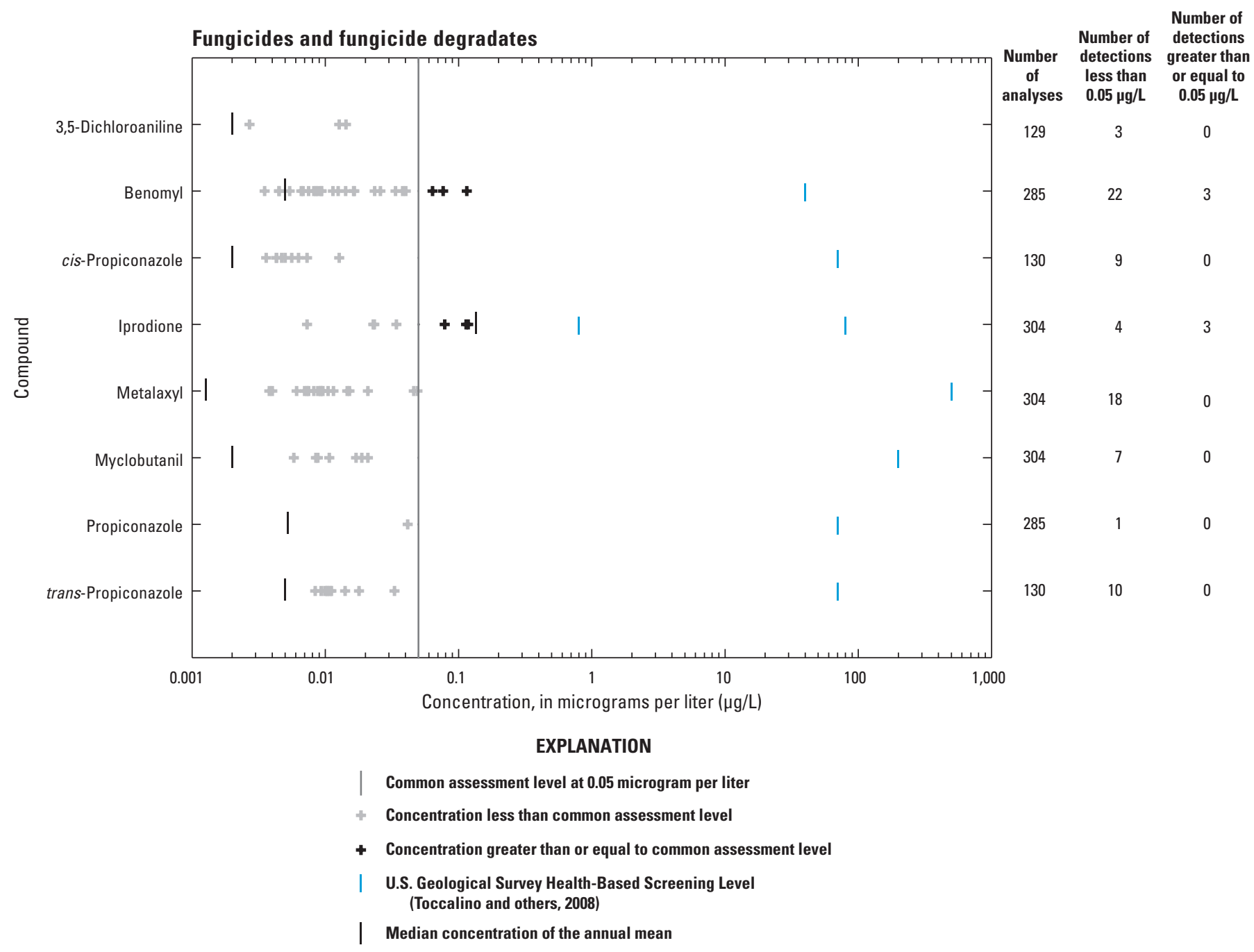

Figure 4-3. Qualified concentrations of fungicides and fungicide degradates compounds in surface water, 2002-10. 


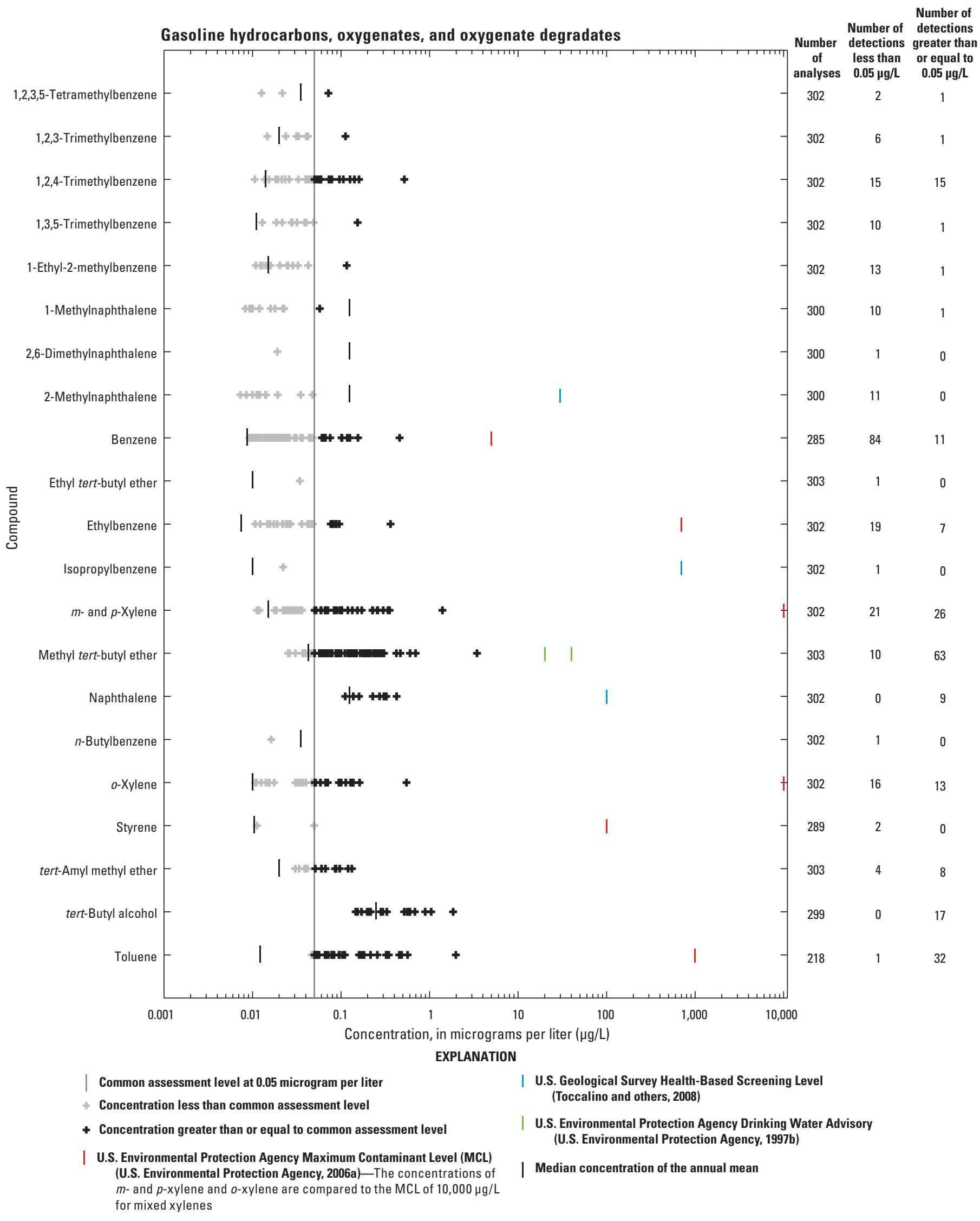

Figure 4-4. Qualified concentrations of gasoline hydrocarbons, oxygenates, and oxygenate degradates in surface water, 2002-10. 


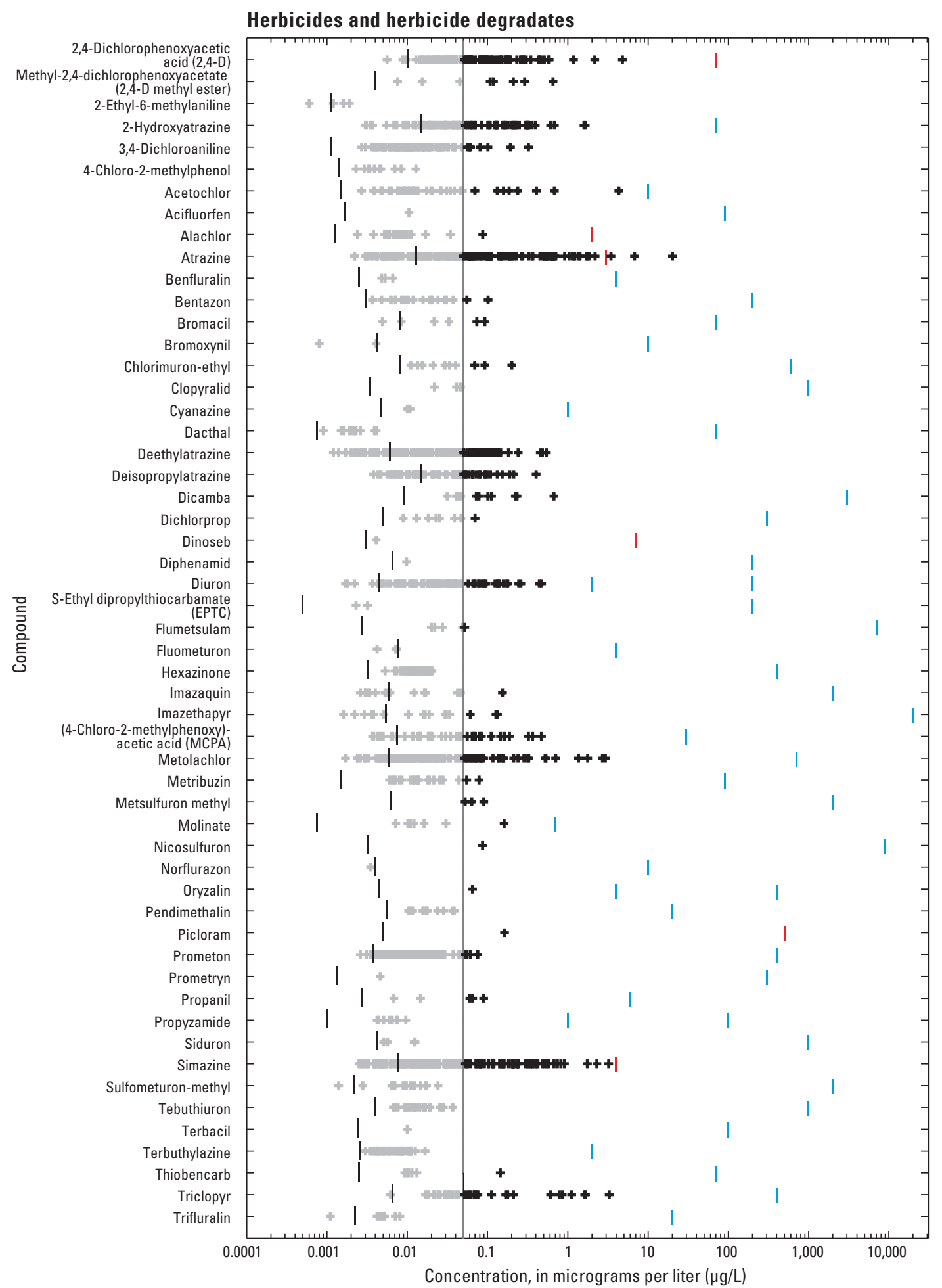

Number of Number of Number detections detections of less than greater than or

2,4-Dichlorophenoxyacetic
acid $(2,4-D)$

thyl-6-methylanilin

Bromac

uron-ethy

Clopyralid

thylatrazin

Herbicides and herbicide degradates

EXPLANATION

$0.05 \mu \mathrm{g} / \mathrm{L}$ equal to $0.05 \mu \mathrm{g} / \mathrm{L}$

$286 \quad 50 \quad 59$

$283 \quad 3 \quad 5$

$\begin{array}{lll}305 & 4 & 0\end{array}$

$282-73 \quad 53$

$\begin{array}{ll}305 & 103\end{array}$

$306-10=8$

$281 \quad 38 \quad 8$

$284-1=0$

$281 \quad 31$

$306 \quad 129$

$306 \quad 3$

$286 \quad 20$

$286 \quad 4$

284

$283 \quad 3$

$130 \quad 2$

$306 \quad 11$

$306 \quad 135$

285

286

\footnotetext{
(Toccalino and others, 2008)

| Median concentration of the annual mean
}

| Common assessment level at 0.05 microgram per liter
$\begin{aligned} & \text { + Concentration less than common assessment level } \\ & \text { U.S. Environmental Protection Agency Maximum Contaminant Level } \\ & \text { (U.S. Environmental Protection Agency, 2006a) }\end{aligned}$

| Common assessment level at 0.05 microgram per liter
$\begin{aligned} & \text { | Concentration less than common assessment level } \\ & \text { (U.S. Environmental Protection Agency, 2006a) }\end{aligned}$

+ Concentration greater than or equal to common assessment level

Figure 4-5. Qualified concentrations of herbicides and herbicide degradates in surface water, 2002-10. 


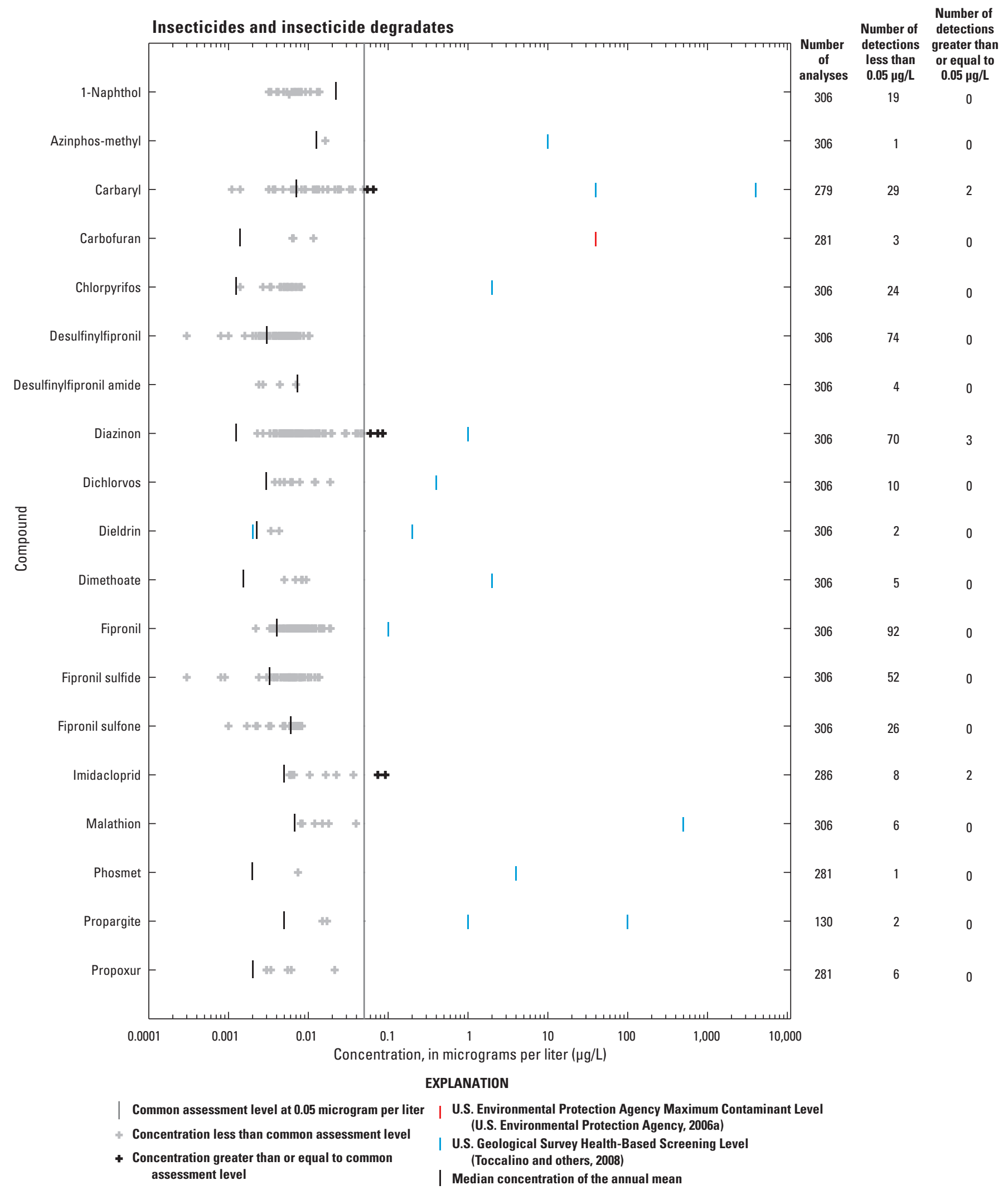

Figure 4-6. Qualified concentrations of insecticides and insecticide degradates in surface water, 2002-10. 


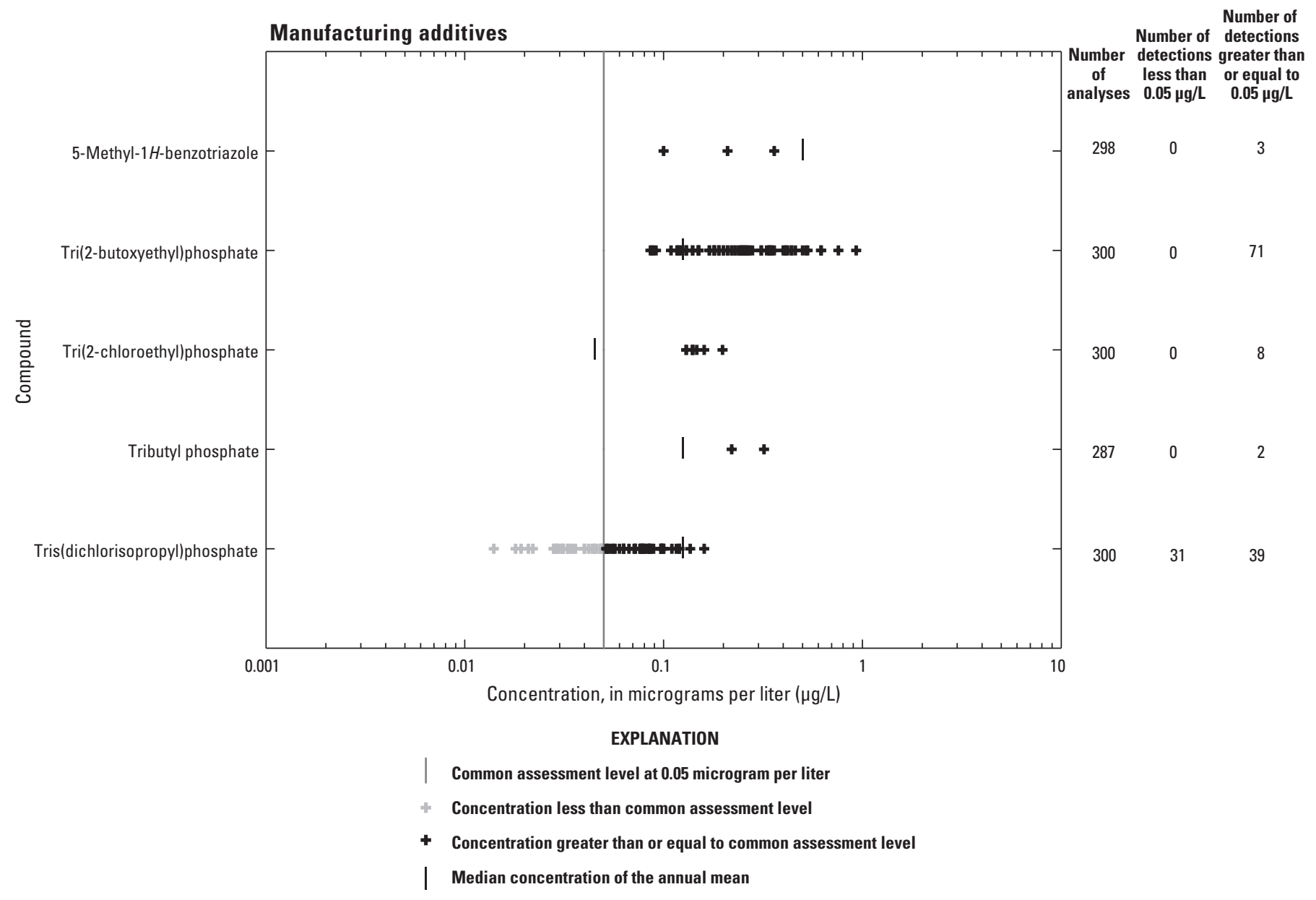

Figure 4-7. Qualified concentrations of manufacturing additives in surface water, 2002-10. 


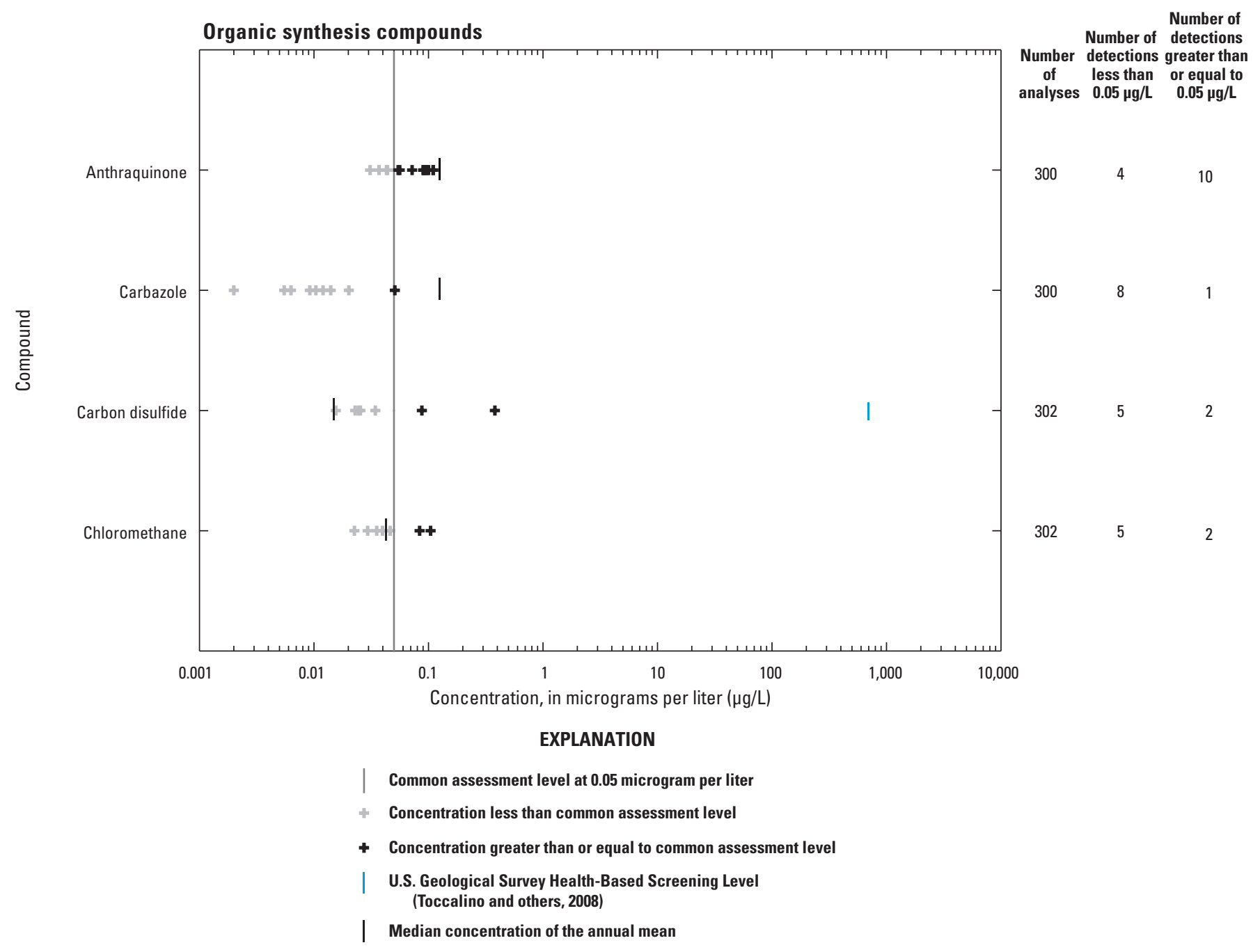

Figure 4-8. Qualified concentrations of organic synthesis compounds in surface water, 2002-10. 


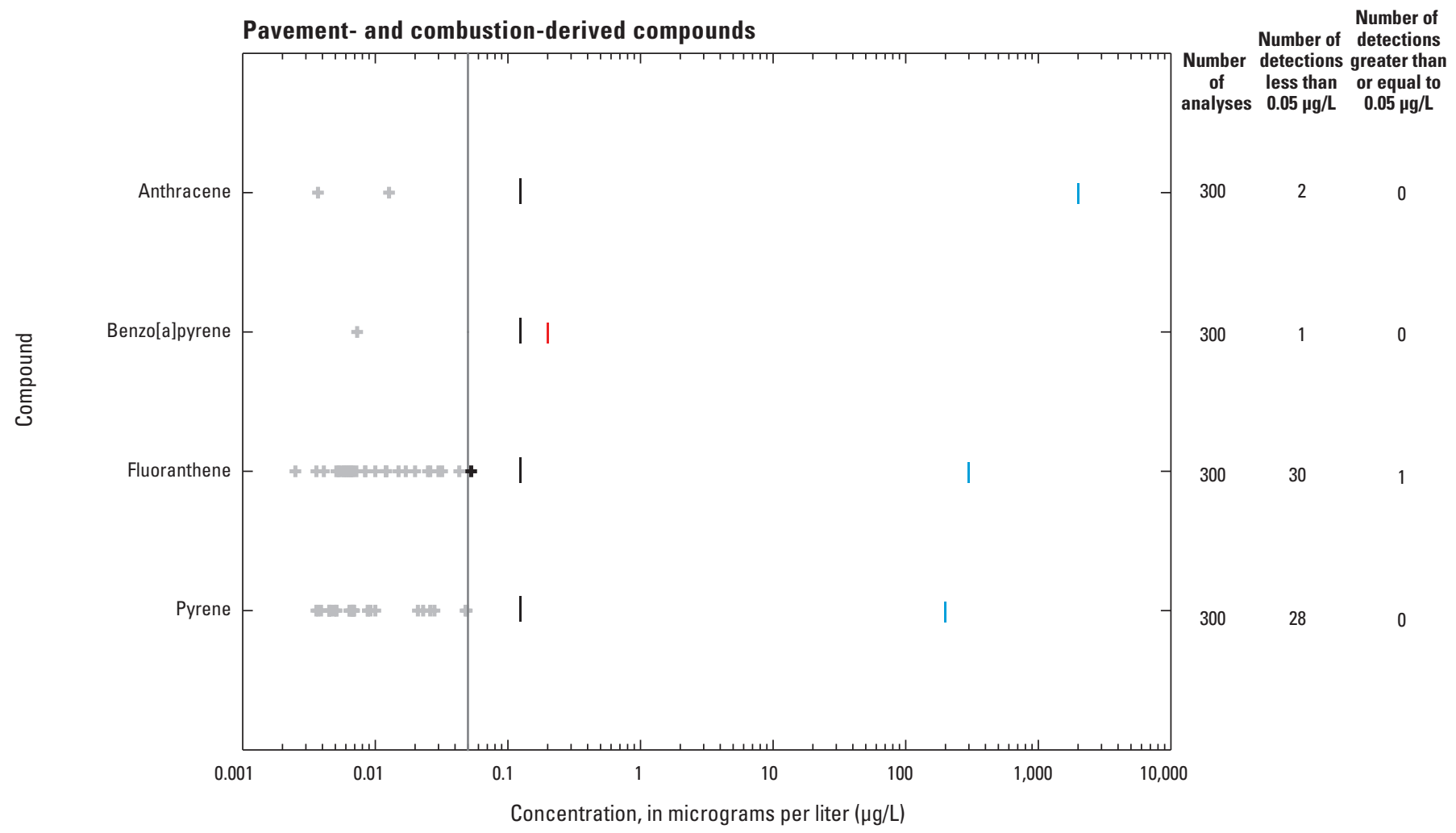

EXPLANATION

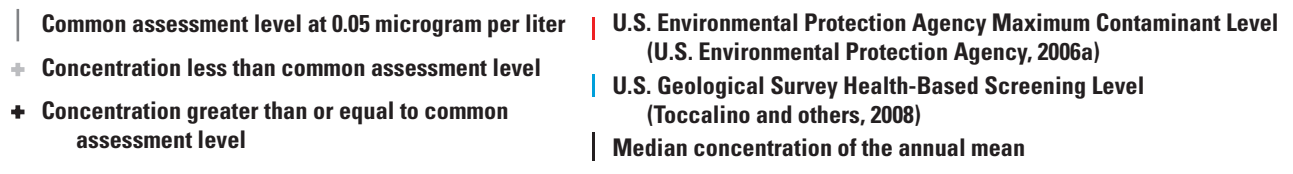

Figure 4-9. Qualified concentrations of pavement- and combustion-derived compounds in surface water, 2002-10. 


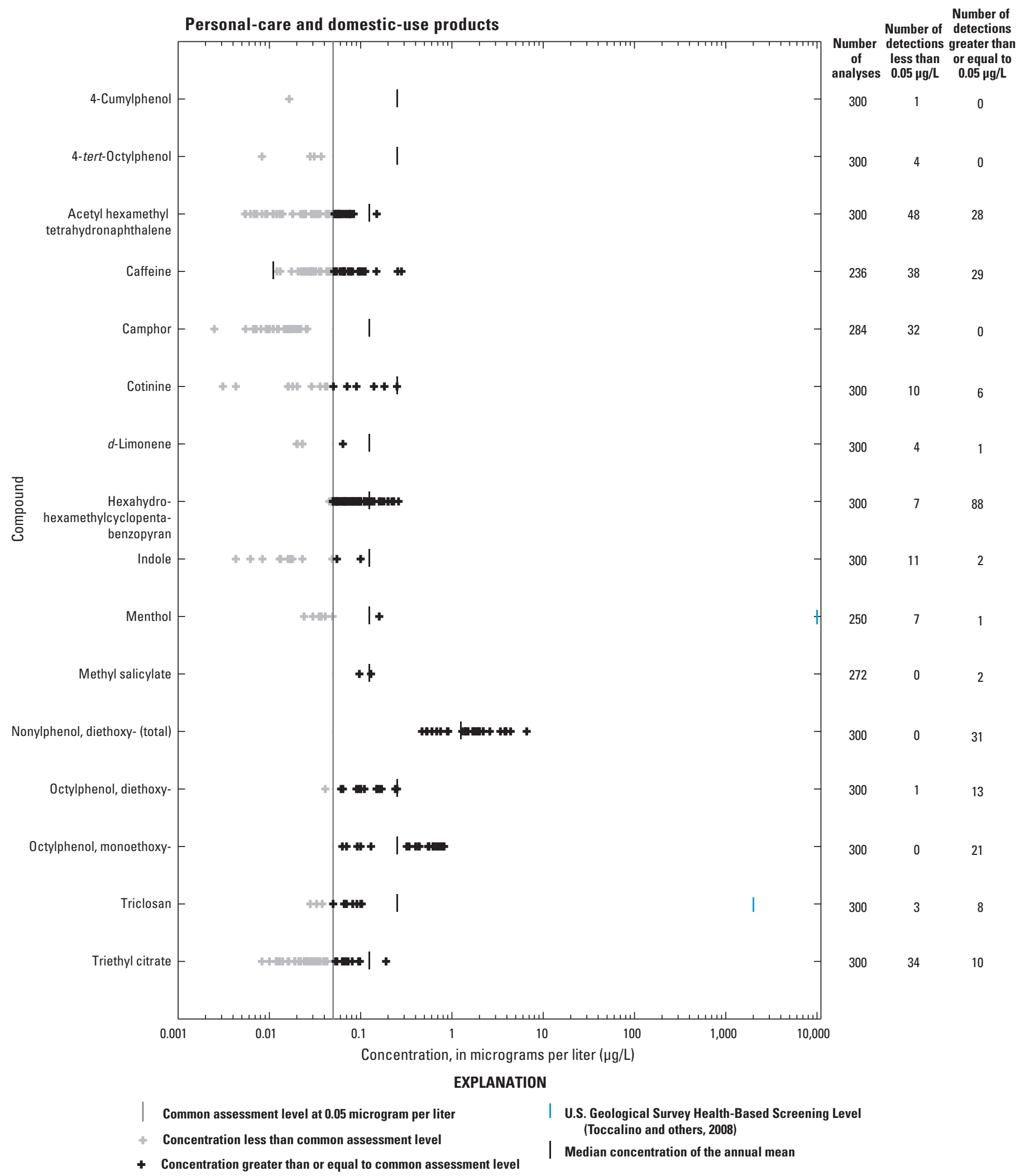

Figure 4-10. Qualified concentrations of personal-care and domestic-use products in surface water, 2002-10. 


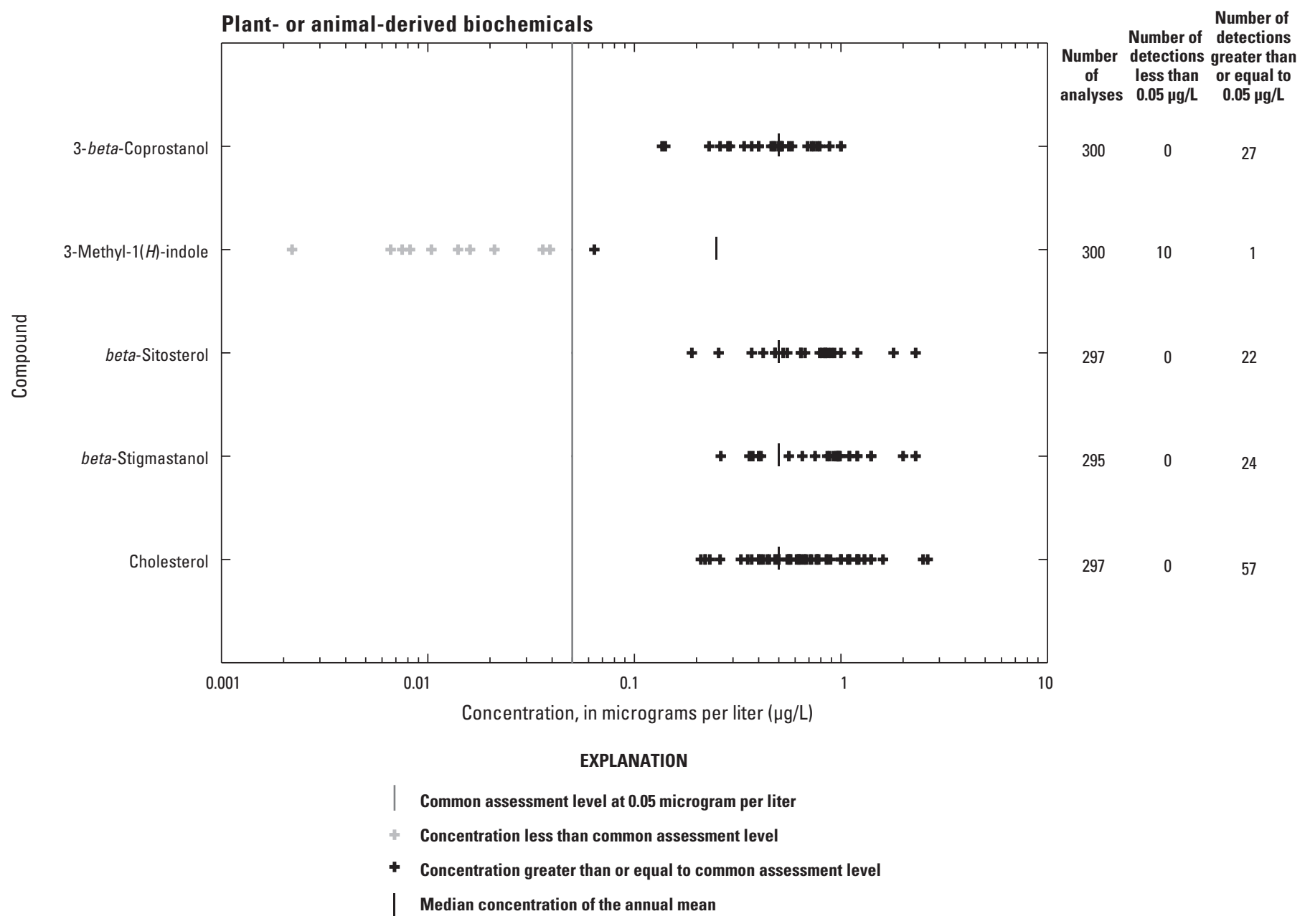

Figure 4-11. Qualified concentrations of plant- or animal-derived biochemicals in surface water, 2002-10. 


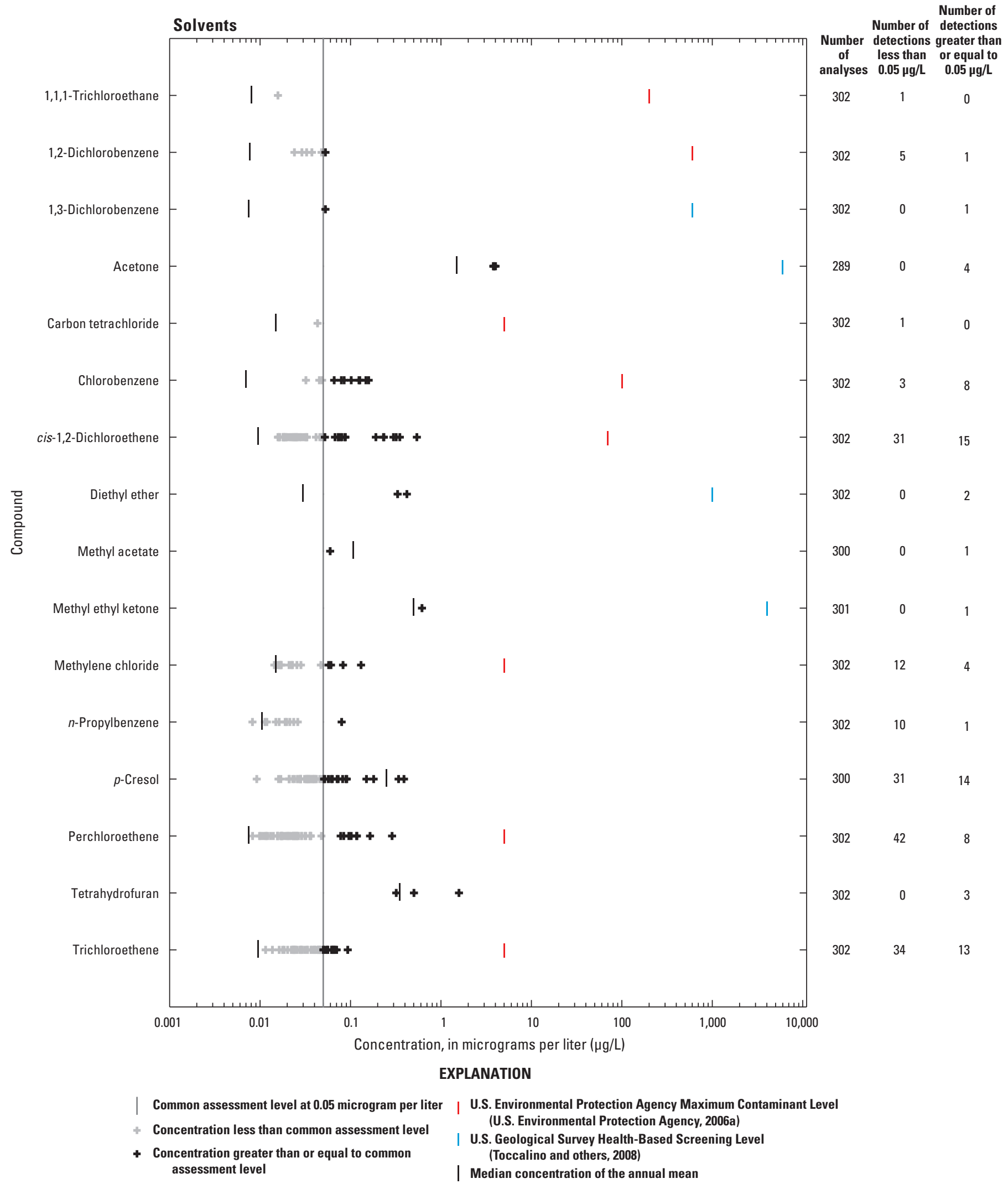

Figure 4-12. Qualified concentrations of of solvents in surface water, 2002-10. 


\section{Appendix 5. Qualified Concentrations of Compounds Monitored in Groundwater During 2002-09 by Primary Use Group and Human-Health Benchmarks (Where Applicable)}

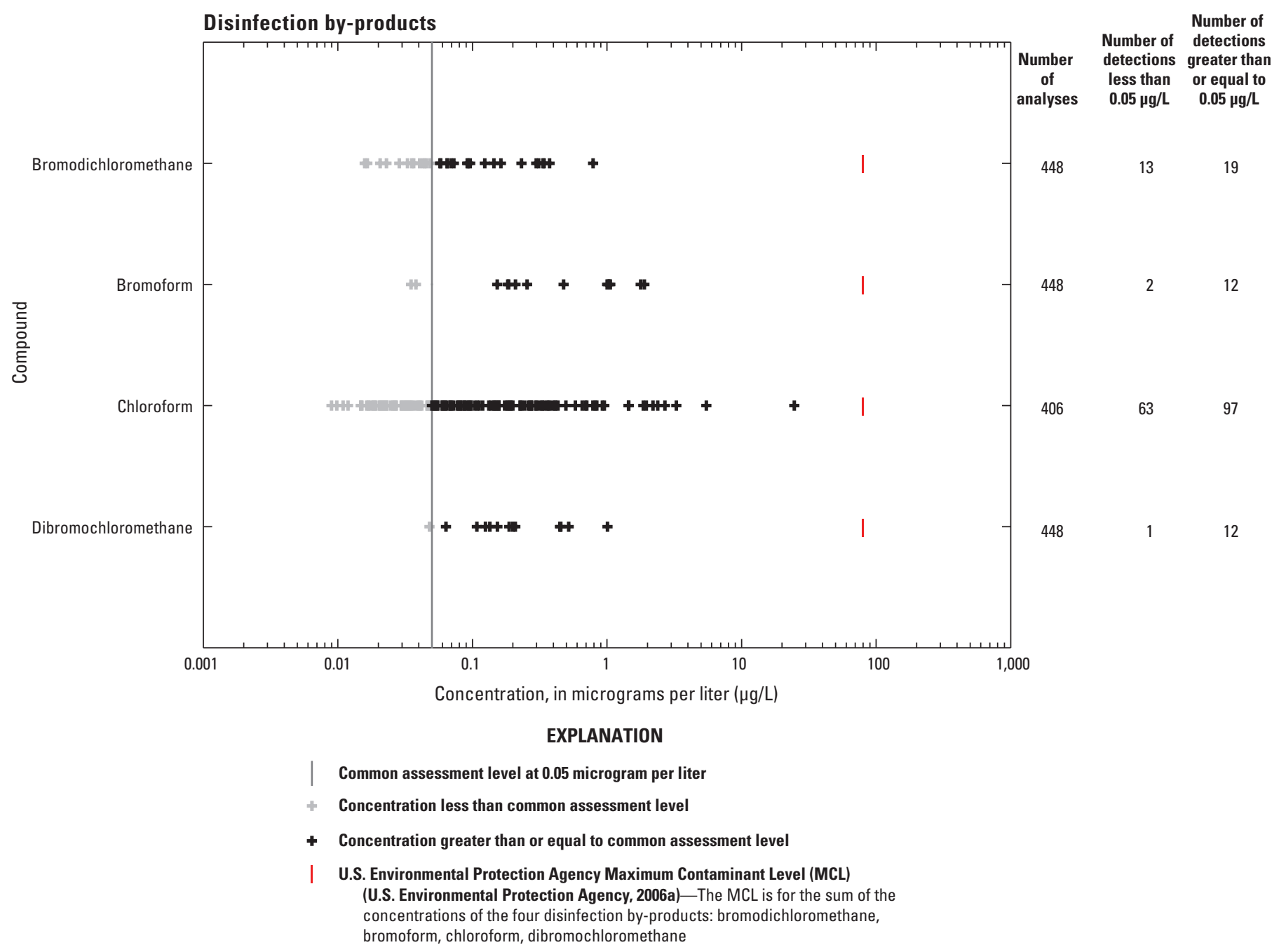

Figure 5-1. Qualified concentrations of disinfection by-products in groundwater, 2002-09. 


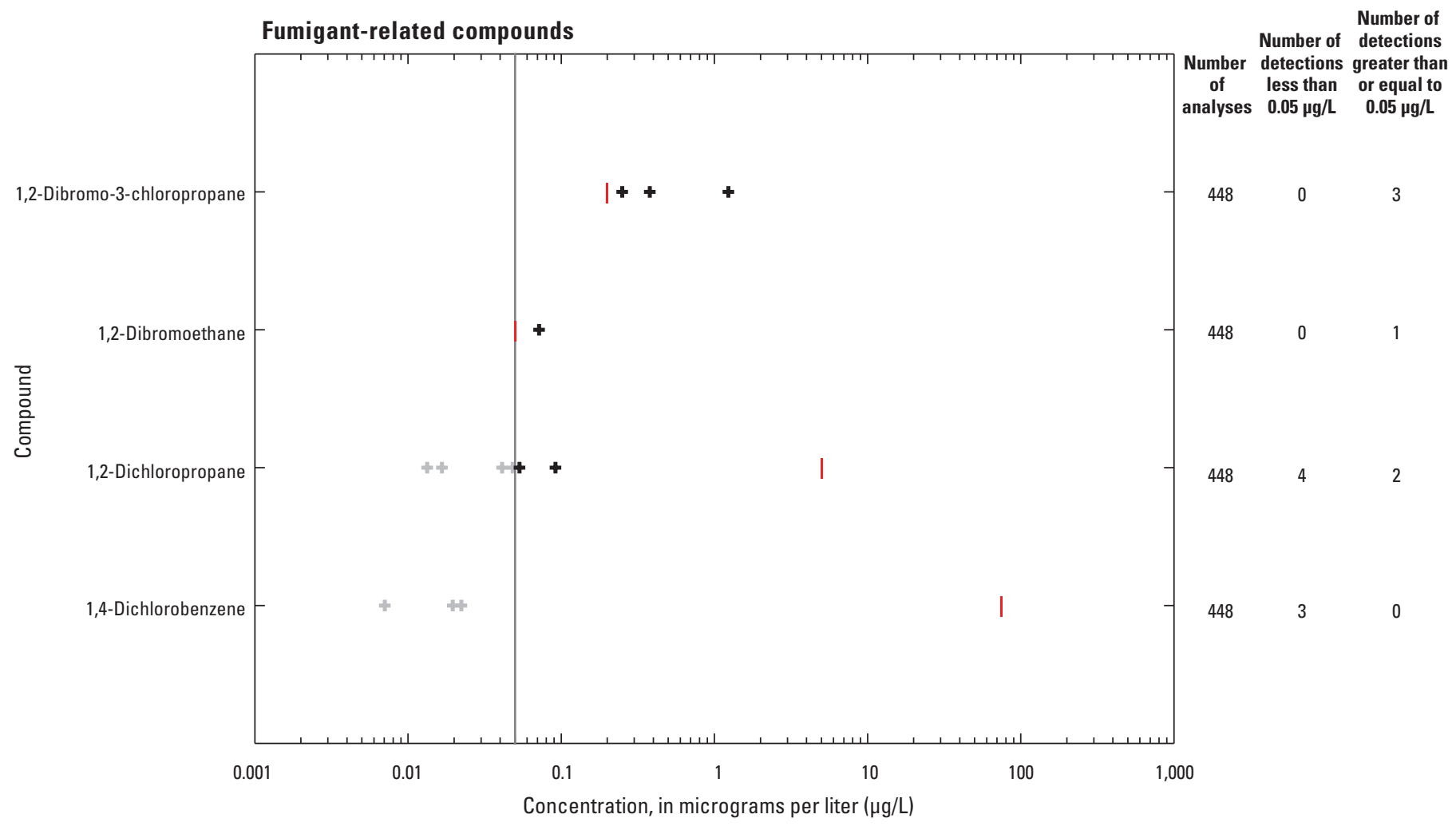

EXPLANATION

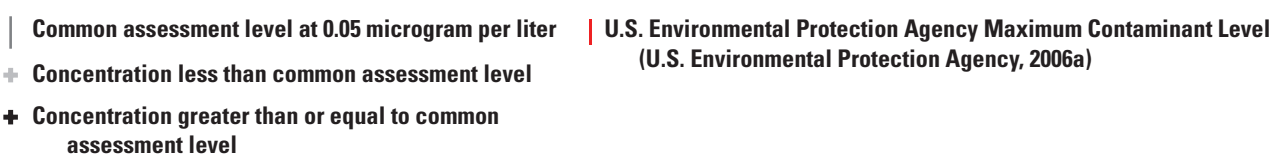

Figure 5-2. Qualified concentrations of fumigant-related compounds in groundwater, 2002-09. 


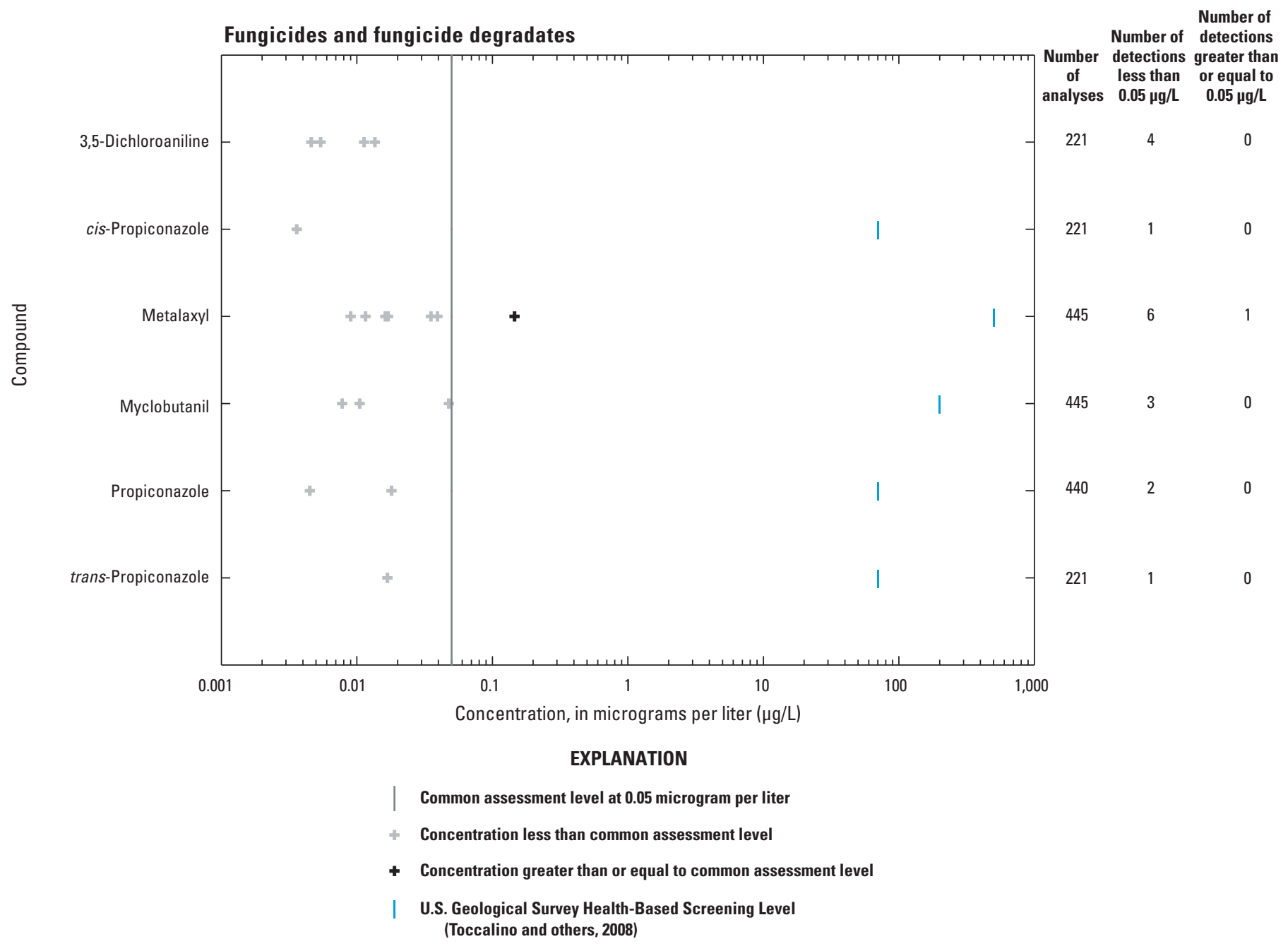

Figure 5-3. Qualified concentrations of fungicides and fungicide degradates compounds in groundwater, 2002-09. 


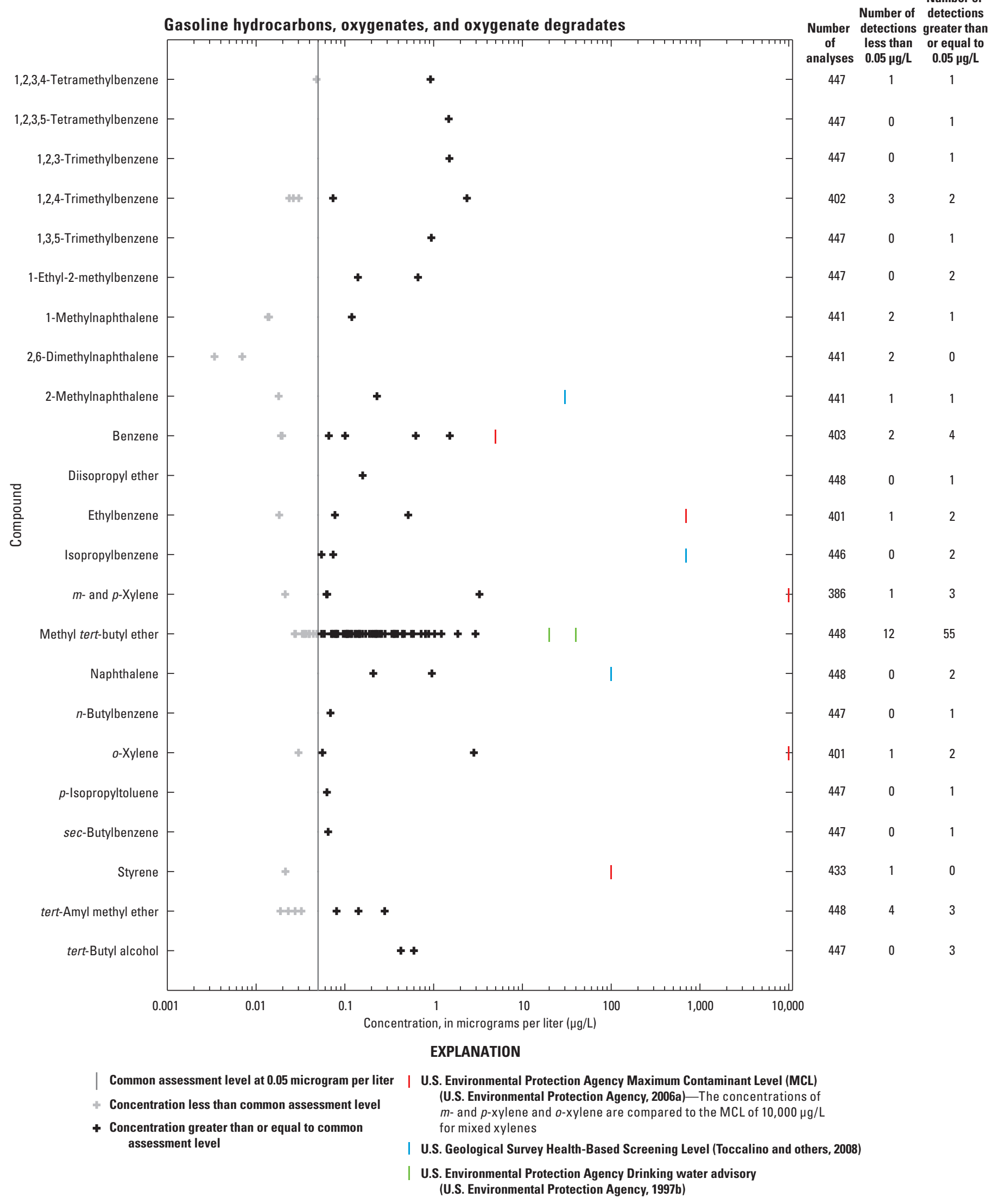

Figure 5-4. Qualified concentrations of gasoline hydrocarbons, oxygenates, and oxygenate degradates in groundwater, 2002-09. 


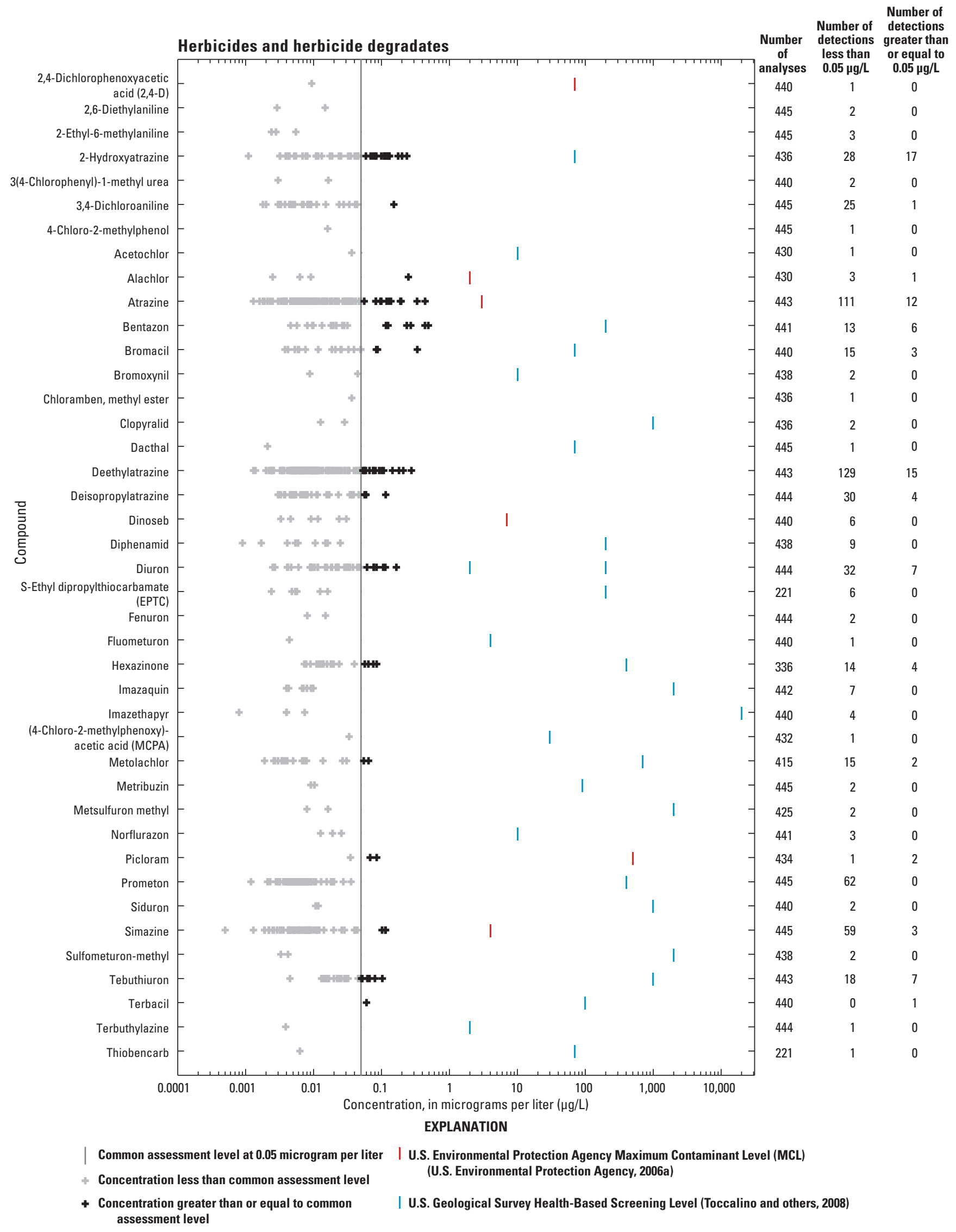

Figure 5-5. Qualified concentrations of herbicides and herbicide degradates in groundwater, 2002-09. 


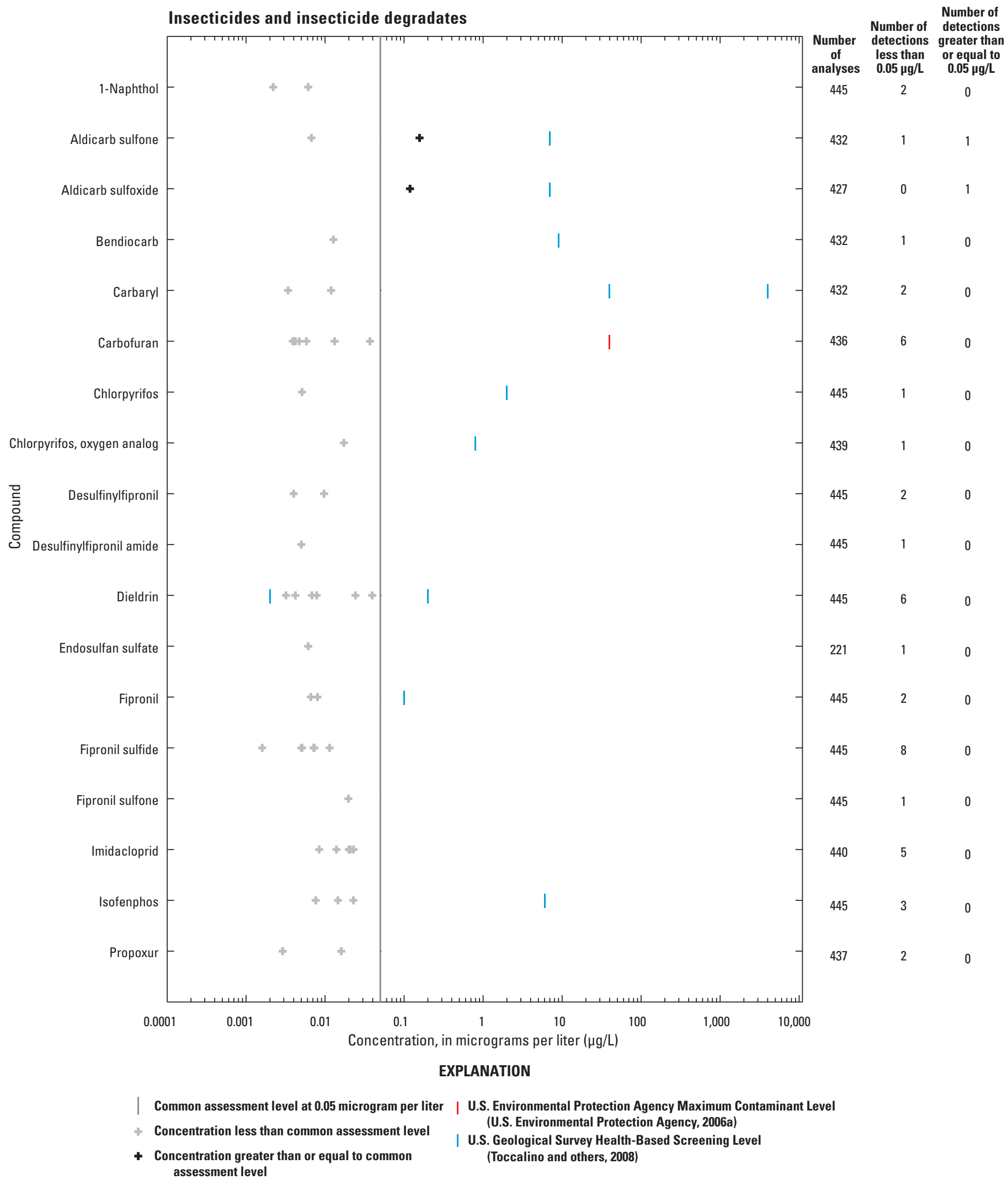

Figure 5-6. Qualified concentrations of insecticides and insecticide degradates in groundwater, 2002-09. 


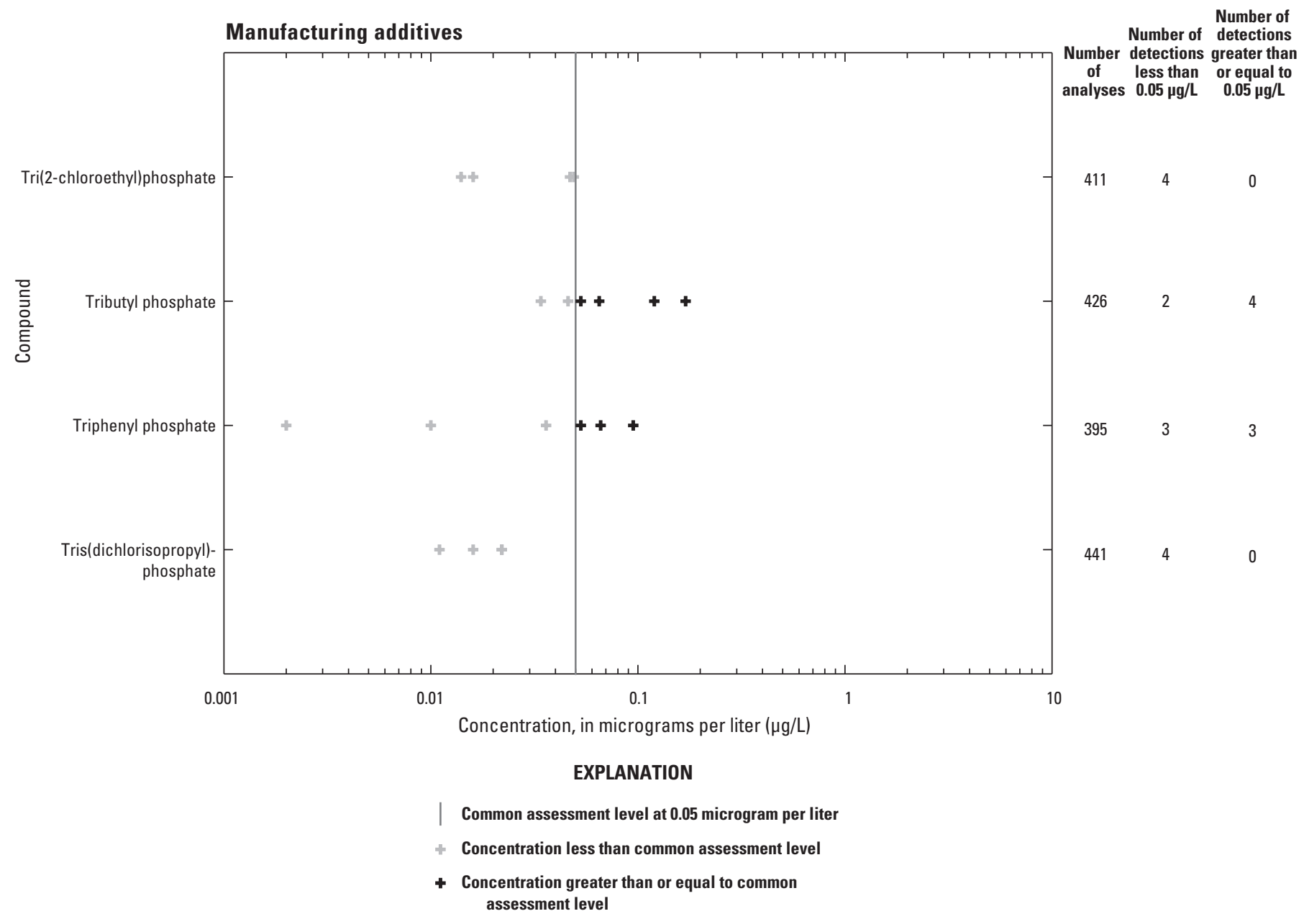

Figure 5-7. Qualified concentrations of manufacturing additives in groundwater, 2002-09. 


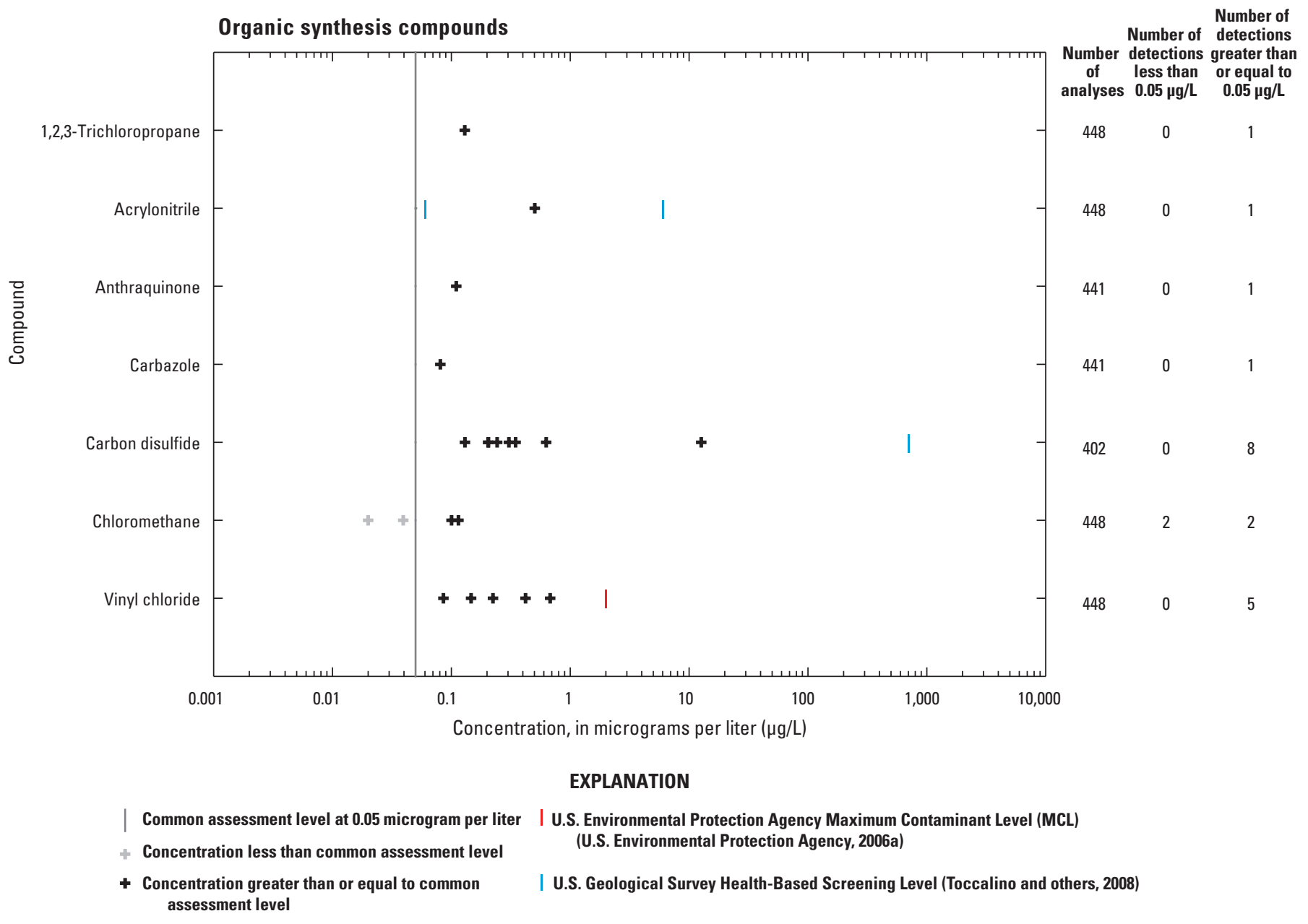

Figure 5-8. Qualified concentrations of organic synthesis compounds in groundwater, 2002-09. 


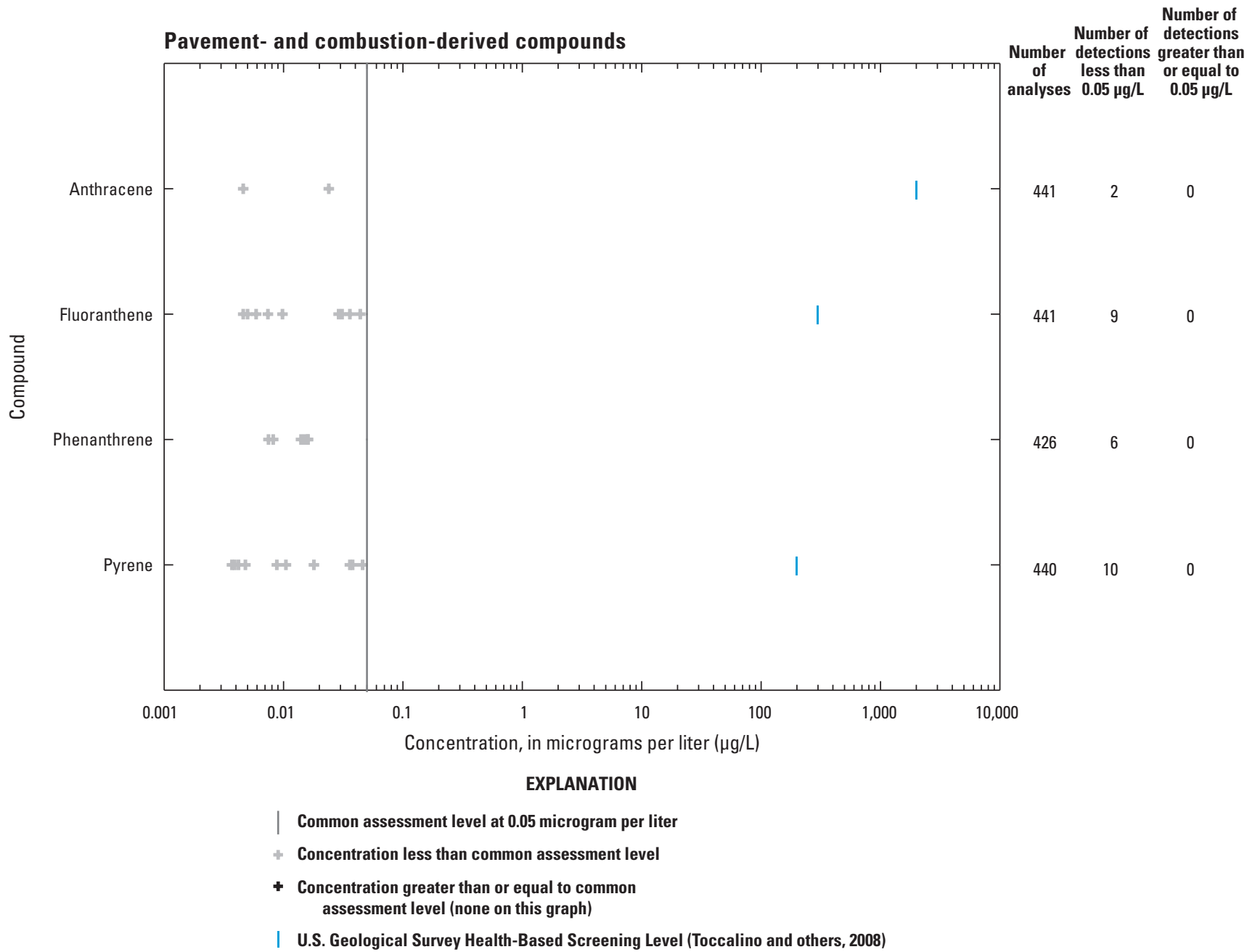

Figure 5-9. Qualified concentrations of pavement- and combustion-derived compounds in groundwater, 2002-09. 


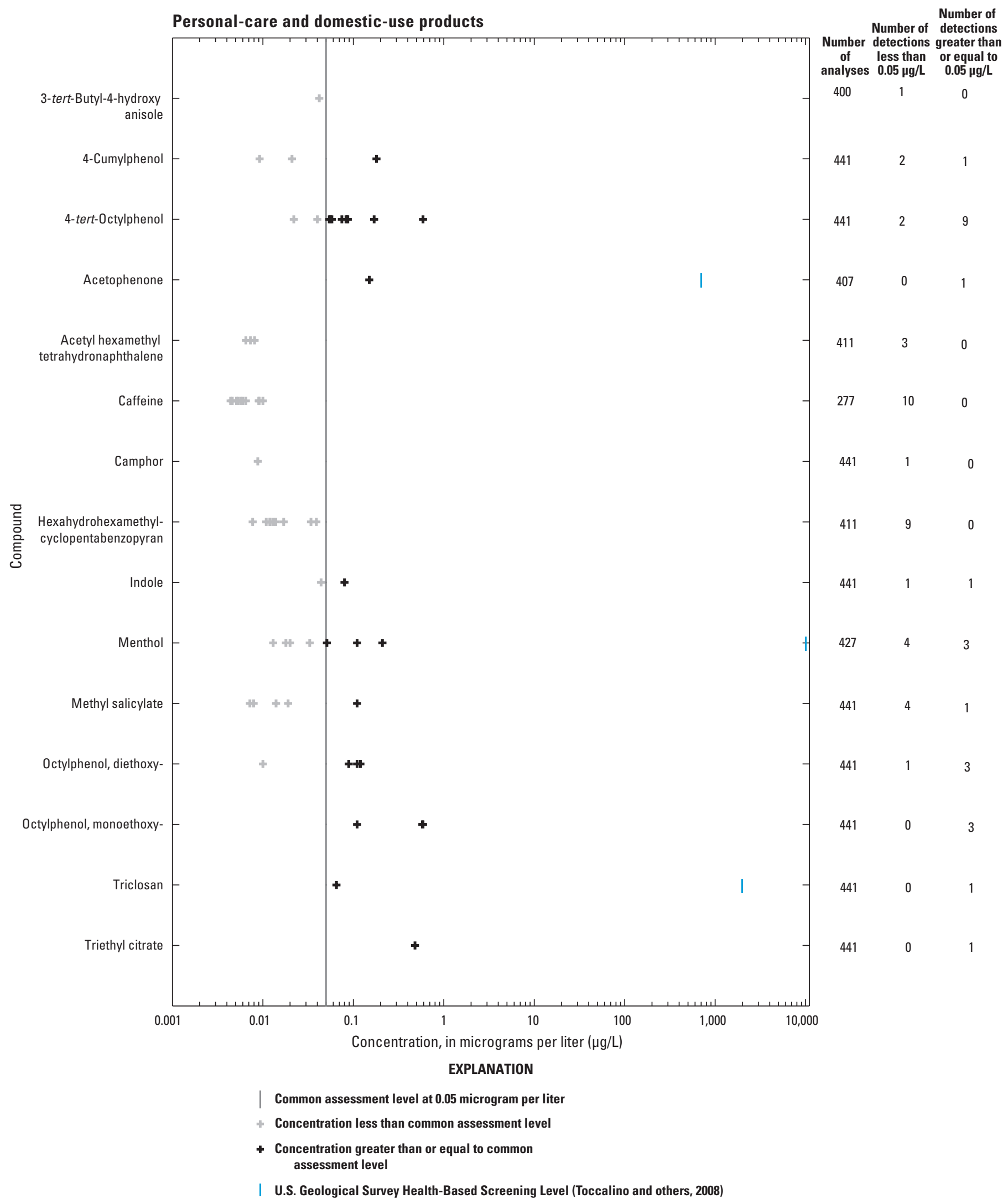

Figure 5-10. Qualified concentrations of personal-care and domestic-use products in groundwater, 2002-09. 


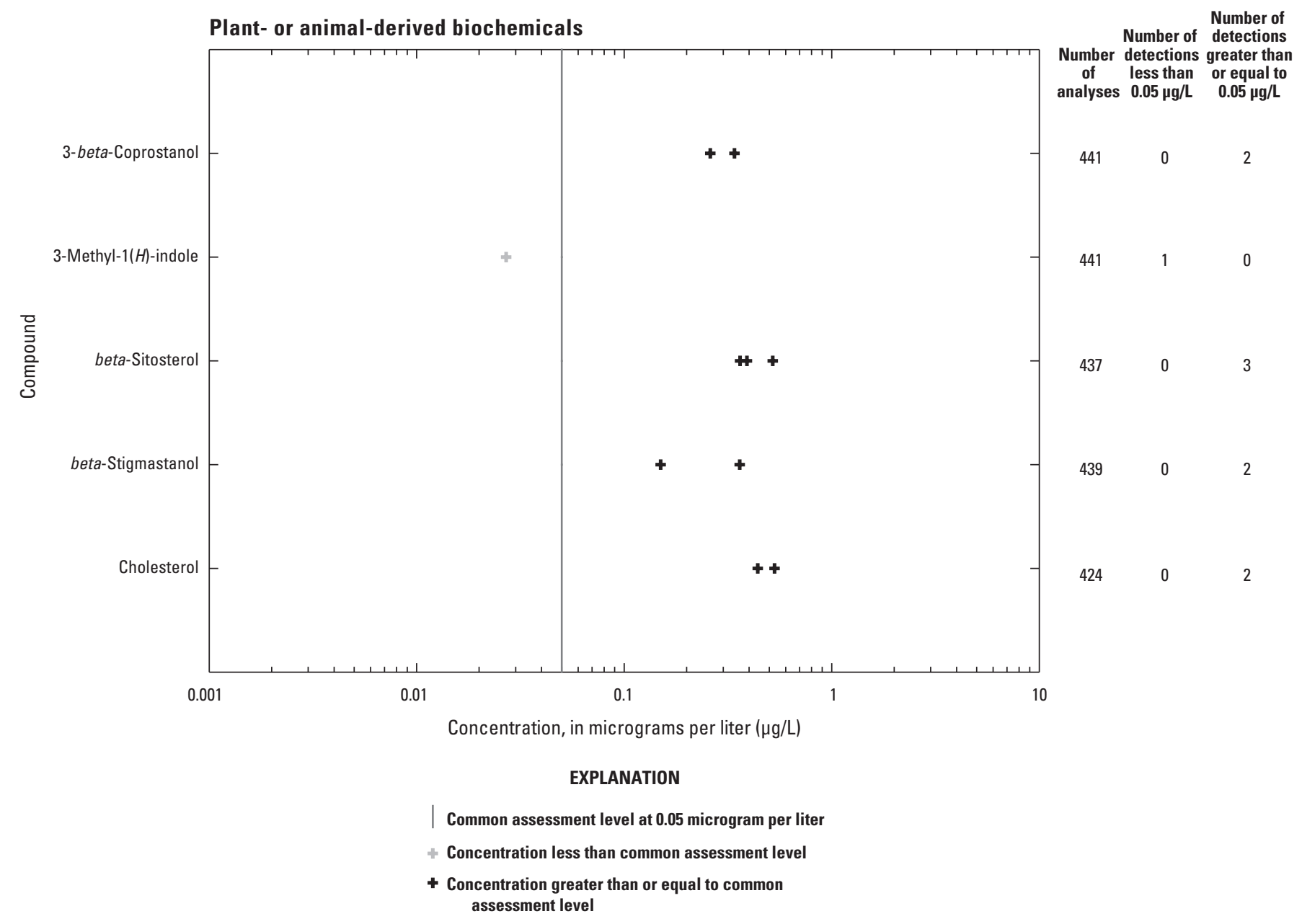

Figure 5-11. Qualified concentrations of plant- or animal-derived biochemicals in groundwater, 2002-09. 


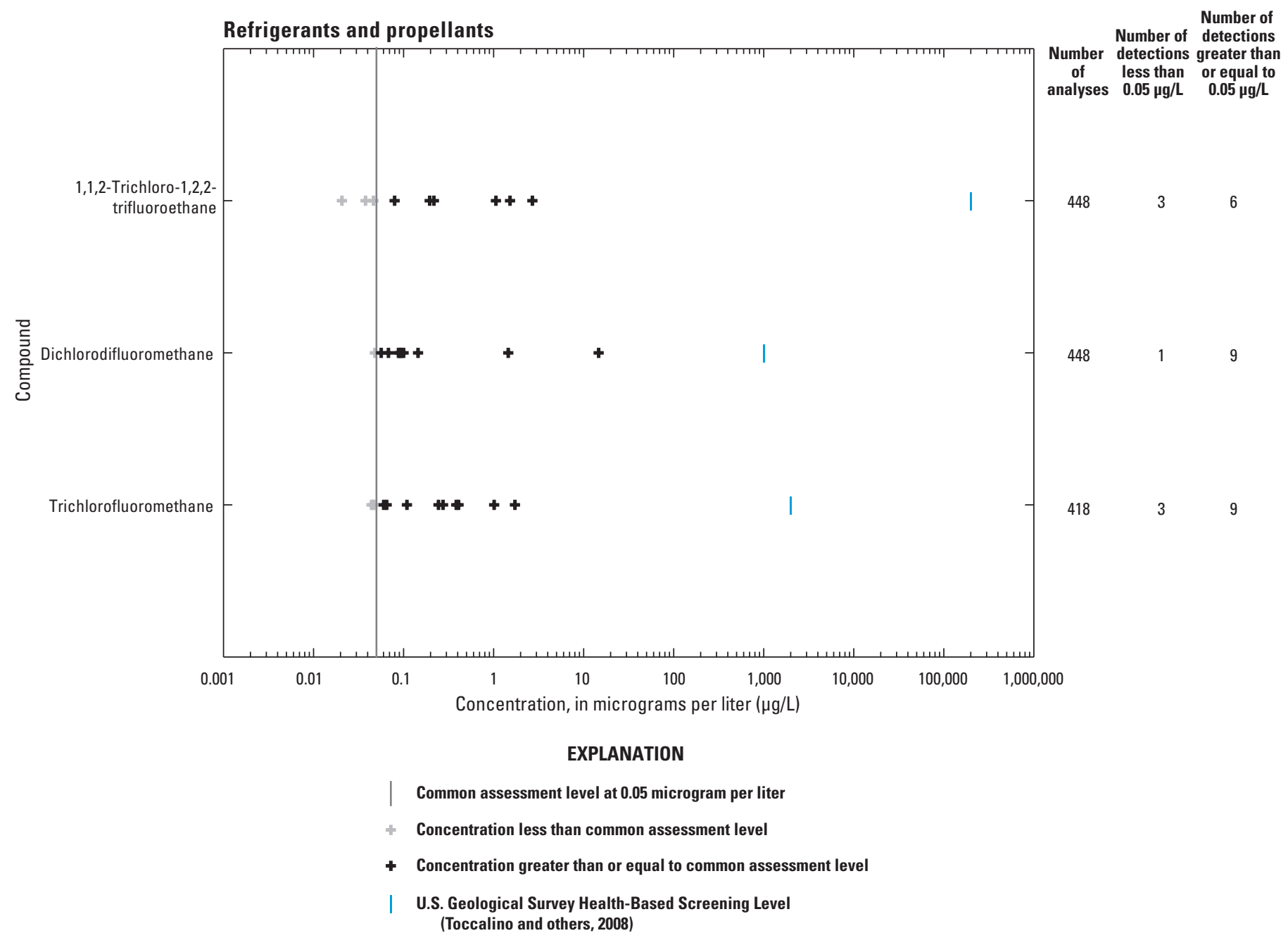

Figure 5-12. Qualified concentrations of refrigerants and propellants in products in groundwater, 2002-09. 


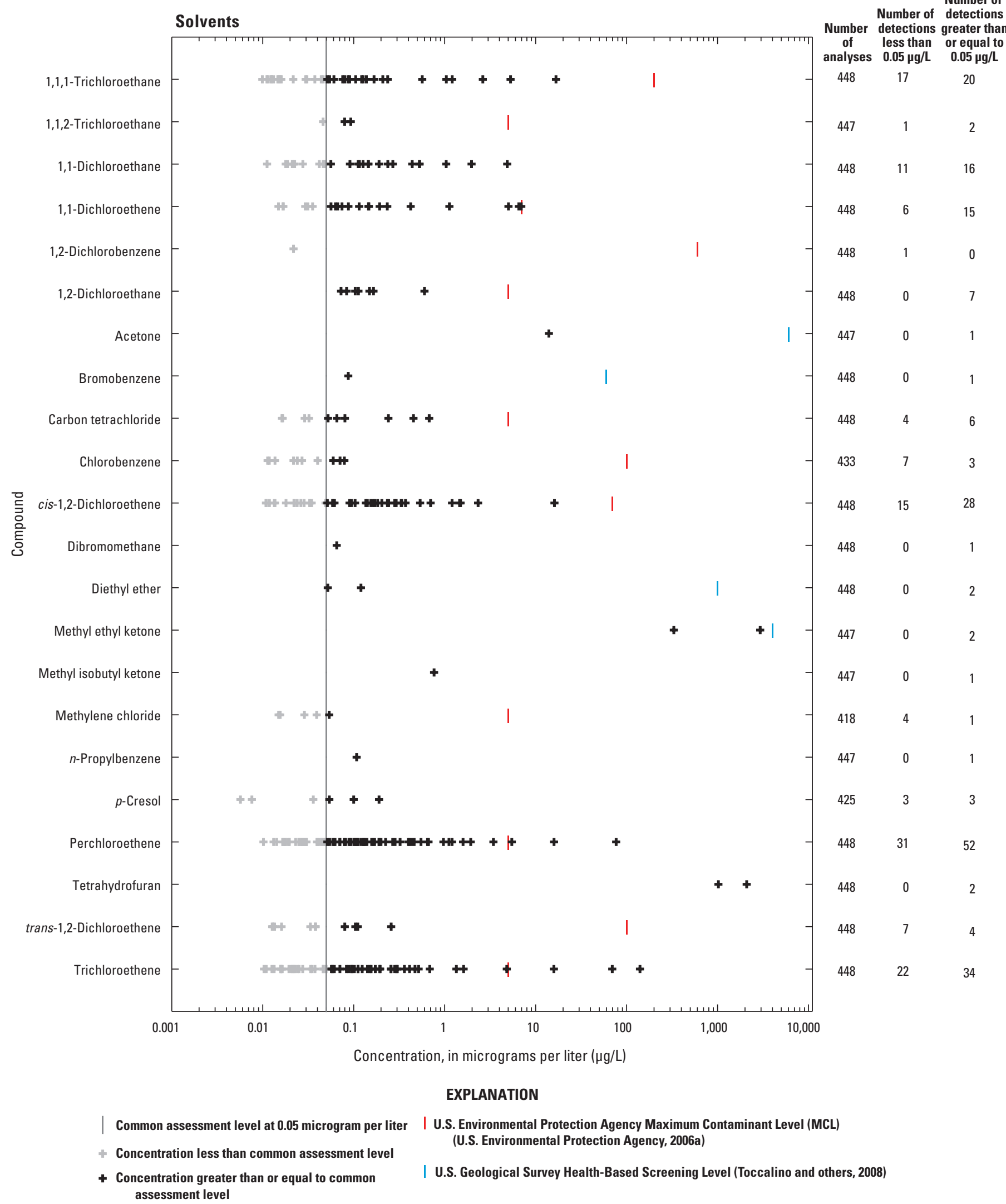

Figure 5-13. Qualified concentrations of solvents in products in groundwater, 2002-09. 
Publishing support provided by: Rolla Publishing Service Center

For more information concerning this publication, contact: Director, USGS South Dakota Water Science Center 1608 Mountain View Road

Rapid City, South Dakota 57702

(605) 394-3200

Or visit the South Dakota Water Science Center Web site at: http://sd.water.usgs.gov/ 



\section{造}

